\title{
Alkyl Carbagermatranes Enable Practical Palladium-Catalyzed sp2-sp3 Cross-Coupling
}

Meng-Yu Xu, Wei-Tao Jiang, Ying Li, Qing-Hao Xu, Qiao-Lan Zhou, Shuo Yang and Bin Xiao*. Department of Chemistry, University of Science and Technology of China, Hefei 230026, China.

\section{Supporting Information}

\section{List of Contents}

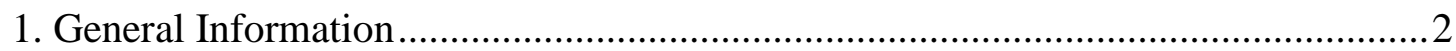

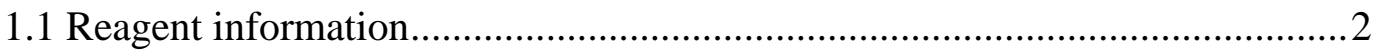

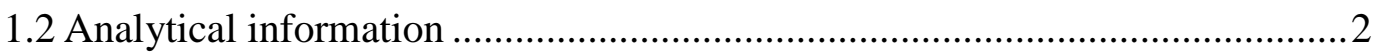

2. Experimental Procedure and Compound Characterization Data for Figure 2-4 .......2

2.1 Preparation of 5-bromo-1-aza-5-germabicyclo[3.3.3] undecane.......................2

2.2 Preparation and characterization data of alkyl iodides .................................. 3

2.2.1 General procedure for the preparation of alkyl iodides ....................... 3

2.2.2 Characterization data of alkyl iodides ............................................... 4

2.3 Preparation and characterization data of alkyl carbagermatranes......................5

2.3.1 General procedure for the preparation of alkyl carbagermatranes..........5

2.3.2 Characterization data of alkyl carbagermatranes and chiral HPLC data 6

2.3.3 Preparation procedure and chiral HPLC data of compound $\mathbf{a 1 8}$..........15

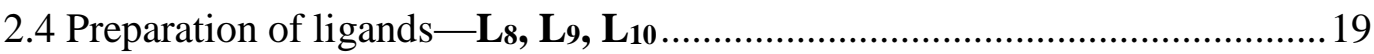

2.5 Preparation and characterization data of cross-coupling products .................21

2.5.1 Preparation of aryl halides and general procedure for cross-coupling

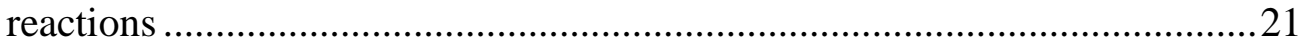

2.5.2 Characterization data of cross-coupling products..............................24

3. Procedure and Characterization Data of Figure 5 .................................................4

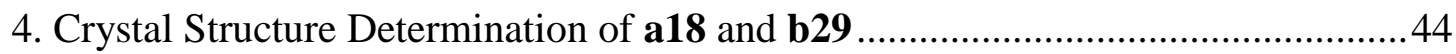

4.1 Experimental procedure and crystal data of a18 ........................................4

4.2 Experimental procedure and crystal data of b29 ........................................50

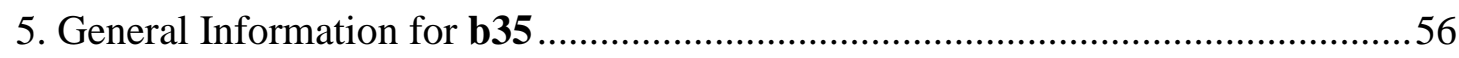

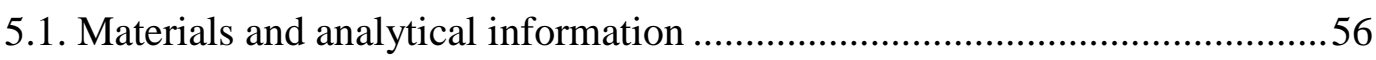

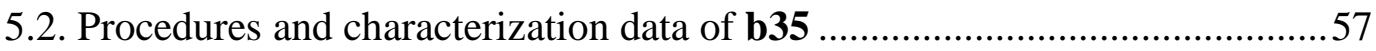

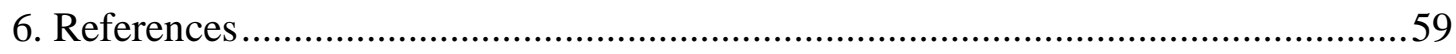

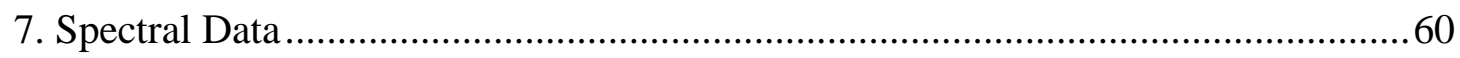




\section{General Information}

\subsection{Reagent information}

All of the reagents were purchased from commercial source and used without further purification unless otherwise noted. $\mathrm{Pd}(\mathrm{dba})_{2}$ was purchased from Adamas-beta. $\mathrm{n}-\mathrm{BuLi}$ (1.6 $\mathrm{M}$ in hexane) and $\mathrm{BnMgCl}$ (1.4M in THF) were purchased from J\&K. Silica gel (HG/T2354-2010) was purchased from Branch Qingdao Haiyang Chemical Co., Ltd. Reagents and solvents were used as received unless otherwise noted.

\subsection{Analytical information}

${ }^{1} \mathrm{H}-\mathrm{NMR}$ spectra were recorded on $400 \mathrm{MHz}$ spectrometers. Chemical shifts of ${ }^{1} \mathrm{H}-\mathrm{NMR}$ spectra were reported in parts per million relative to tetramethylsilane $(\delta=$ $0)$. Data for ${ }^{1} \mathrm{H}-\mathrm{NMR}$ were reported as follows: chemical shift ( $\left.\delta \mathrm{ppm}\right)$, multiplicity, coupling constant $(\mathrm{Hz})$, and integration. ${ }^{13} \mathrm{C}-\mathrm{NMR}$ spectra were recorded on $100 \mathrm{MHz}$ spectrometers. Chemical shifts were reported in parts per million relative to the solvent resonance as the internal standard $\left(\mathrm{CDCl}_{3}, \delta 77.2 \mathrm{ppm} ; \mathrm{C}_{6} \mathrm{D}_{6}, \delta 128.1 \mathrm{ppm}\right.$; $\left(\mathrm{CD}_{3}\right)_{2} \mathrm{CO}, \delta 30.0 \mathrm{ppm} \& \delta 206.3 \mathrm{ppm}$; $\left.\left(\mathrm{CD}_{3}\right)_{2} \mathrm{SO}, \delta 39.5 \mathrm{ppm}\right)$. Data for ${ }^{13} \mathrm{C}-\mathrm{NMR}$ are reported in terms of chemical shift $(\delta$ ppm), multiplicity, and coupling constant $(\mathrm{Hz})$. High-resolution mass spectra (HRMS) were recorded on an Acquity UPLC-Xevo G2 QTof instrument with ESI mode unless otherwise stated. Single crystal structure analyses were performed on an Oxford diffraction Gemini S Ultra instrument. Gas chromatographic (GC) analysis was acquired on a Shimadzu GC-2014 Series GC system equipped with a flame-ionization detector. Organic solutions were concentrated under reduced pressure on a Buchi rotary evaporator. Chromatographic purification of products was accomplished using column chromatography or preparative TLC (Thin-layer chromatogram) on silica gel.

\section{Experimental Procedure and Compound Characterization Data for Figure 2-4}

\subsection{Preparation of 5-bromo-1-aza-5-germabicyclo[3.3.3]undecane}

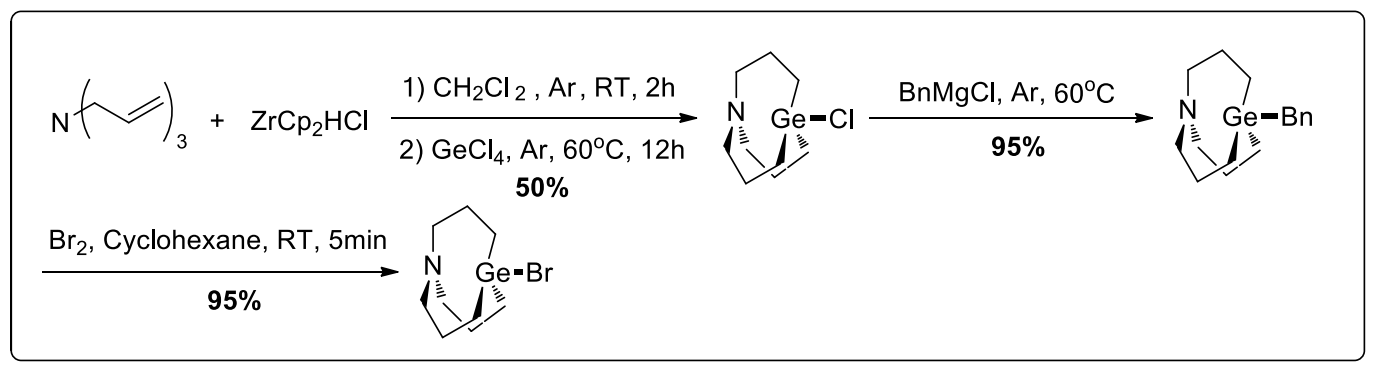

All reactions were performed in oven-dried glassware under an atmosphere of Ar.

1) Synthesis of 5-chloro-1-aza-5-germabicyclo[3.3.3] undecane: $\mathrm{ZrCp} 2 \mathrm{HCl}$ was prepared by a literature procedure ${ }^{1}$. A $250 \mathrm{~mL}$ screw-cap flask was charged with $\mathrm{ZrCp}_{2} \mathrm{HCl}(13 \mathrm{~g}, 51.6 \mathrm{mmol}), \mathrm{CH}_{2} \mathrm{Cl}_{2}(50 \mathrm{~mL})$ and triallylamine $(2.5 \mathrm{~mL}, 14.4 \mathrm{mmol})$, 
the resulting mixture was stirred at room temperature for 2 hours. Then fresh distilled $\mathrm{GeCl}_{4}(2 \mathrm{~mL}, 17.2 \mathrm{mmol})$ was added dropwise to the mixture, which was heated at 60 ${ }^{\circ} \mathrm{C}$ for 12 hours later. After that the mixture was cooled to room temperature, $100 \mathrm{~mL}$ petroleum ether was poured into the flask to cast out most of the byproduct as precipitates. Then filtered and solvent was removed under vacuo to afford crude product as yellow solid, which was used without further purification. Yield was found to be $50 \%$ (determined by ${ }^{1} \mathrm{H}-\mathrm{NMR}$ spectra with mesitylene as internal standard).

2) Synthesis of 5-bromo-1-aza-5-germabicyclo[3.3.3] undecane: The crude product obtained from above was dissolved in anhydrous THF $(30 \mathrm{~mL}), \mathrm{BnMgCl}(10.3 \mathrm{~mL}$, $1.4 \mathrm{M}$ in THF, $14.4 \mathrm{mmol}$ ) was added at room temperature before vigorous stirring at $60{ }^{\circ} \mathrm{C}$ for 6 hours. The reaction was quenched with $\mathrm{NH}_{4} \mathrm{Cl}$ sat. and extracted with petroleum ether $(100 \mathrm{~mL})$. The organic phase was separated and dried over $\mathrm{MgSO}_{4}$ and concentrated in vacuo to afford the 5-benzyl-1-aza-5-germabicyclo[3.3.3] undecane which could be purified by silica gel column chromatography (100-200 mesh) using petroleum ether as eluent $\left(R_{f}=0.8\right)$. To a solution of 5-benzyl-1-aza-5-germabicyclo[3.3.3] undecane in cyclohexane, $\mathrm{Br}_{2}$ was added dropwise at room temperature until the color of the solution stopped fading. Then the filtration of the mixture gave white powder with a yield of $90 \%(1.9 \mathrm{~g})$.

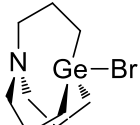

5-bromo-1-aza-5-germabicyclo[3.3.3] undecane. ${ }^{1} \mathrm{H}$ NMR (400 $\left.\mathbf{~ M H z ,} \mathbf{C D C l}_{3}\right) \delta 2.63$ $(\mathrm{t}, J=6.0 \mathrm{~Hz}, 6 \mathrm{H}), 1.87-1.77(\mathrm{~m}, 6 \mathrm{H}), 1.55(\mathrm{t}, J=6.9 \mathrm{~Hz}, 6 \mathrm{H}),{ }^{13} \mathbf{C} \mathbf{~ N M R}\left(\mathbf{1 0 1} \mathbf{~ M H z}, \mathbf{C D C l}_{\mathbf{3}}\right)$ 855.1, 23.0, 21.4. HRMS (ESI) Calcd for $\left[\mathrm{C}_{9} \mathrm{H}_{18} \mathrm{GeN}\right]^{+}[\mathrm{M}-\mathrm{Br}]^{+}: 214.0651$; Found: $214.0658 .{ }^{1} \mathbf{H}$ NMR (400 MHz, $\left.\mathbf{C D}_{2} \mathrm{Cl}_{2}\right) \delta 2.60(\mathrm{t}, J=6.0 \mathrm{~Hz}, 6 \mathrm{H}), 1.86-1.73(\mathrm{~m}, 6 \mathrm{H}), 1.47(\mathrm{t}, J=6.9 \mathrm{~Hz}, 6 \mathrm{H})$ (Relative to the solvent resonance as the internal standard: $\mathrm{CD}_{2} \mathrm{Cl}_{2}, \delta 5.33 \mathrm{ppm}$ )

\subsection{Preparation and characterization data of alkyl iodides}

\subsubsection{General procedure for the preparation of alkyl iodides}

\section{Procedure A:}

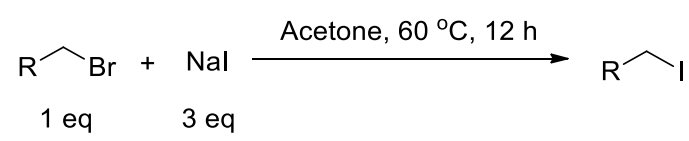

To a sealed tube equipped with a magnetic stir bar, the corresponding alkyl- $\mathrm{Br}$ (3 mmol, 1 eq), NaI (9 mmol, $3 \mathrm{eq})$ and acetone $(3 \mathrm{~mL})$ were added and stirred at $60{ }^{\circ} \mathrm{C}$ for 12 hours. After cooling at room temperature, $\mathrm{CH}_{2} \mathrm{Cl}_{2}$ was added until the complete precipitation of salts. Then, the mixture was filtered and the filtrate was removed under vacuum. The product was purified by column chromatography.

\section{Procedure B:}

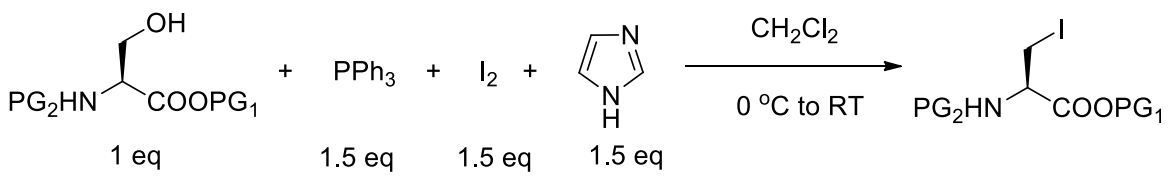

To a solution of $\mathrm{PPh}_{3}(15 \mathrm{mmol}, 1.5 \mathrm{eq})$ and imidazole (15 mmol, $\left.1.5 \mathrm{eq}\right)$ in $\mathrm{CH}_{2} \mathrm{Cl}_{2}$ 
$(50 \mathrm{~mL})$ in a $200 \mathrm{~mL}$ flask, $\mathrm{I}_{2}(15 \mathrm{mmol}, 1.5 \mathrm{eq})$ was added in three portions at $0{ }^{\circ} \mathrm{C}$. The mixture was stirred at $0{ }^{\circ} \mathrm{C}$ for $10 \mathrm{~min}$ and then stirred at room temperature for 15 min. Afterwards, a solution of protected serine (10 mmol, $1 \mathrm{eq})$ in $\mathrm{CH}_{2} \mathrm{Cl}_{2}(10 \mathrm{~mL})$ was added to the mixture at $0{ }^{\circ} \mathrm{C}$. The reaction was stirred at room temperature for 4 hours. To the reaction was added an aqueous solution of sodium thiosulfate until the mixture became colorless. The reaction was extracted with $\mathrm{CH}_{2} \mathrm{Cl}_{2}(50 \mathrm{~mL})$. The organic phase was separated and dried over $\mathrm{MgSO}_{4}$ and concentrated in vacuo to afford the crude product which could be purified by silica gel column chromatography or by recrystallization.

\subsubsection{Characterization data of alkyl iodides}

$\Upsilon_{\mathrm{CN}}^{\mathrm{C}}$ 5-iodopentanenitrile. The product was synthesized via Procedure A which could be isolated by silica gel column chromatography (300-400 mesh) using EtOAc/Petroleum ether (1/50) as eluent with a yield of $92 \%$ (colorless oil). ${ }^{1} \mathbf{H} \mathbf{~ N M R ~}\left(\mathbf{4 0 0} \mathbf{~ M H z}, \mathbf{C D C l}_{\mathbf{3}}\right) \delta 3.22(\mathrm{t}, J$ $=6.6 \mathrm{~Hz}, 2 \mathrm{H}), 2.40(\mathrm{t}, J=7.0 \mathrm{~Hz}, 2 \mathrm{H}), 2.06-1.91(\mathrm{~m}, 2 \mathrm{H}), 1.86-1.74(\mathrm{~m}, 2 \mathrm{H}) .{ }^{13} \mathbf{C}$ NMR $(101$ MHz, $\left.\mathbf{C D C l}_{3}\right) \delta 119.2,31.9,26.3,16.3$, 4.6. All spectral data was in accordance with the literature ${ }^{2}$.<smiles>O=C1c2ccccc2C(=O)N1CCCCI</smiles>

2-(4-iodobutyl)isoindoline-1,3-dione. The product was synthesized via

Procedure A which could be isolated by silica gel column chromatography (300-400 mesh) using EtOAc/Petroleum ether (1/4) as eluent with a yield of 95\% (white solid). ${ }^{1} \mathbf{H}$ NMR (400 $\mathbf{~ M H z}$, $\left.\mathbf{C D C l}_{3}\right) \delta 7.90-7.81(\mathrm{~m}, 2 \mathrm{H}), 7.76-7.67(\mathrm{~m}, 2 \mathrm{H}), 3.72(\mathrm{t}, J=6.8 \mathrm{~Hz}, 2 \mathrm{H}), 3.23(\mathrm{t}, J=6.7 \mathrm{~Hz}$, 2H), $1.95-1.68$ (m, 4H). ${ }^{13} \mathbf{C}$ NMR (101 MHz, $\left.\mathbf{C D C l}_{3}\right) \delta 168.5,134.1,132.2,123.4,36.9,30.7$, 29.7, 5.7. All spectral data was in accordance with the literature ${ }^{2}$.

$ح_{\text {BPin }}^{2-(5-i o d o p e n t y l)-4,4,5,5-t e t r a m e t h y l-1,3,2-d i o x a b o r o l a n e . ~ T h e ~ p r o d u c t ~ w a s ~}$ synthesized via Procedure A which could be isolated by silica gel column chromatography (300-400 mesh) using EtOAc/Petroleum ether (1/50) as eluent with a yield of 95\% (colorless oil). ${ }^{1} \mathbf{H}$ NMR (400 MHz, CDCl $\left.)_{3}\right) \delta 3.19(\mathrm{t}, J=7.1 \mathrm{~Hz}, 2 \mathrm{H}), 1.93-1.76(\mathrm{~m}, 2 \mathrm{H}), 1.52-1.33(\mathrm{~m}, 4 \mathrm{H})$, 1.25 (s, 12H), 0.79 (t, $J=7.4 \mathrm{~Hz}, 2 \mathrm{H}) .{ }^{13} \mathbf{C}$ NMR (101 MHz, $\left.\mathbf{C D C l}_{3}\right) \delta 83.1,33.5,33.3,25.0,23.1$, 7.5. All spectral data was in accordance with the literature ${ }^{3}$.<smiles>[B][B]C([Pb])CCCI</smiles>

2,2'-(11-iodoundecane-1,1-diyl)bis(4,4,5,5-tetramethyl-1,3,2-dioxaborolane). According to the literature ${ }^{4}$, to a schlenk flask equipped with a tefloncoated magnetic stir bar, diborylmethane $(10 \mathrm{mmol})$ was added, then the vessel was evacuated and filled with argon for three times. Under an argon atmosphere, anhydrous THF $(30 \mathrm{~mL})$ was added. Before the solution was stirred for $5 \mathrm{~min}$, lithium diisopropylamide (11mmol) was added dropwise at $0{ }^{\circ} \mathrm{C}$. 1,3-diiodopropane $(10 \mathrm{mmol})$ was added at the same tempurature. After that, the reaction mixture was allowed to warm to room temperature and stirred for 2 hours. When reaction completed, reaction mixture was quenched by $\mathrm{NH}_{4} \mathrm{Cl}$ (aq) and diluted with EtOAc, Then organic layer was dried over $\mathrm{Na}_{2} \mathrm{SO}_{4}$ (s), filtered and concentrated in vacuo. The product could be isolated by silica 
gel column chromatography (300-400 mesh) using EtOAc/Petroleum ether (1/30) as eluent with a yield of $65 \%$ (thick oil). ${ }^{1} \mathbf{H}$ NMR (400 $\left.\mathbf{M H z}, \mathbf{C D C l}_{3}\right) \delta 3.15(\mathrm{t}, J=7.3 \mathrm{~Hz}, 2 \mathrm{H}), 1.89-1.81(\mathrm{~m}$, 2H), $1.70-1.53(\mathrm{~m}, 2 \mathrm{H}), 1.23(\mathrm{~d}, J=3.5 \mathrm{~Hz}, 24 \mathrm{H}), 0.73(\mathrm{t}, J=7.9 \mathrm{~Hz}, 1 \mathrm{H}) .{ }^{13} \mathbf{C}$ NMR (101 MHz, $\left.\mathbf{C D C l}_{3}\right) \delta 83.2,36.6,26.8,25.0,24.6,6.7$. HRMS (ESI) Calcd for $\left[\mathrm{C}_{16} \mathrm{H}_{31} \mathrm{~B}_{2} \mathrm{INaO}_{4}\right]^{+}[\mathrm{M}+\mathrm{Na}]^{+}$: 459.1351; Found: 459.1355.

${ }_{\mathrm{BocHN}}^{\mathrm{I}} \curlywedge_{\mathrm{COOMe}}$

(R)-methyl 2-((tert-butoxycarbonyl)amino)-3-iodopropanoate. The product was synthesized via Procedure B which could be isolated by silica gel column chromatography (100-200 mesh) using EtOAc/Petroleum ether (1/10) as eluent with a yield of $80 \%$ (white solid). ${ }^{1} \mathbf{H}$ NMR (400 MHz, $\left.\mathbf{C D C l}_{3}\right) \delta 5.36(\mathrm{~d}, J=6.4 \mathrm{~Hz}, 1 \mathrm{H}), 4.53(\mathrm{dt}, J=7.6,3.8 \mathrm{~Hz}$, 1H), 3.80 (s, 3H), 3.61 - 3.54 (m, 2H), 1.46 (s, 9H). ${ }^{13} \mathbf{C}$ NMR (101 MHz, CDCl $) \delta$ 170.1, 154.8, 80.5, 53.7, 53.0, 28.3, 7.9. All spectral data was in accordance with the literature ${ }^{5}$.

${ }_{\mathrm{CbzHN}}^{1} \nearrow_{\mathrm{COOBn}}$

(R)-benzyl 2-(((benzyloxy)carbonyl)amino)-3-iodopropanoate. The product was synthesized via Procedure B which could be isolated by silica gel column chromatography (100-200 mesh) using EtOAc/Petroleum ether (1/10) as eluent with a yield of $78 \%$ (white solid). ${ }^{1} \mathbf{H}$ NMR (400 MHz, $\left.\mathbf{C D C l}_{3}\right) \delta 7.52-7.28(\mathrm{~m}, 10 \mathrm{H}), 5.66(\mathrm{~d}, J=7.4 \mathrm{~Hz}, 1 \mathrm{H}), 5.32-4.99(\mathrm{~m}$, 4H), $4.61(\mathrm{dt}, J=7.5,3.8 \mathrm{~Hz}, 1 \mathrm{H}), 3.62-3.55$ (m, 2H). ${ }^{13} \mathbf{C}$ NMR (101 MHz, CDCl $) \delta 169.1$, $155.4,135.9,134.7,128.7,128.7,128.6,128.6,128.3,128.1,68.1,67.3,54.1,7.3$. All spectral data was in accordance with the literature ${ }^{6}$.

Fmochn $\chi_{\text {COOAllyl }}^{\prime}$

(R)-allyl

2-(((9H-fluoren-9-yl)methoxy)carbonyl)amino)-3-iodopropanoate. The product was synthesized via Procedure B which could be isolated by silica gel column chromatography (100-200 mesh) using EtOAc/Petroleum ether (1/4) as eluent with a yield of $80 \%$ (white solid). ${ }^{1} \mathbf{H}$ NMR (400 MHz, CDCl $) \delta 7.76(\mathrm{~d}, J=7.5 \mathrm{~Hz}, 2 \mathrm{H}), 7.61(\mathrm{~d}, J=7.4 \mathrm{~Hz}, 2 \mathrm{H}), 7.42-7.38(\mathrm{~m}, 2 \mathrm{H})$, $7.34-7.30(\mathrm{~m}, 2 \mathrm{H}), 5.98-5.89(\mathrm{~m}, 1 \mathrm{H}), 5.69(\mathrm{~d}, J=7.3 \mathrm{~Hz}, 1 \mathrm{H}), 5.38(\mathrm{~d}, J=17.2 \mathrm{~Hz}, 1 \mathrm{H}), 5.30$ $(\mathrm{d}, J=10.4 \mathrm{~Hz}, 1 \mathrm{H}), 4.78-4.64(\mathrm{~m}, 2 \mathrm{H}), 4.61-4.58(\mathrm{~m}, 1 \mathrm{H}), 4.44-4.35(\mathrm{~m}, 2 \mathrm{H}), 4.25(\mathrm{t}, J=$ $7.2 \mathrm{~Hz}, 1 \mathrm{H}), 3.62(\mathrm{~d}, J=2.9 \mathrm{~Hz}, 2 \mathrm{H}) .{ }^{13} \mathbf{C}$ NMR (101 MHz, CDCl$) \delta 169.0,155.4,143.7,143.6$, 141.3, 131.1, 127.8, 127.1, 127.1, 125.1, 125.1, 120.0, 119.6, 67.4, 66.9, 54.0, 47.1, 7.4. HRMS (ESI) Calcd for $\left[\mathrm{C}_{21} \mathrm{H}_{20} \mathrm{INO}_{4} \mathrm{Na}\right]^{+}[\mathrm{M}+\mathrm{Na}]^{+}: 500.0335$; Found: 500.0344.

\subsection{Preparation and characterization data of alkyl carbagermatranes}

\subsubsection{General procedure for the preparation of alkyl carbagermatranes}

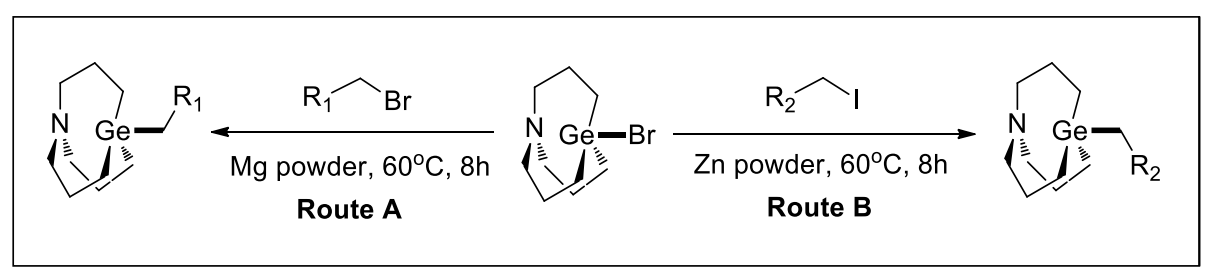


$\mathrm{Mg}$ powder was purchased from commercial source and used without further treatment and $\mathrm{Zn}$ powder needed to be activated following the procedure. In a $100 \mathrm{~mL}$ flask equipped with a tefloncoated magnetic stir bar, $\mathrm{Zn}$ powder $(10 \mathrm{~g})$ was weighed and transferred, then diluted $\mathrm{HCl}$ aq $(20 \mathrm{~mL})$ was added. The mixture was stirred at room temperature for 2-3 hours, filtered, washed with $\mathrm{H}_{2} \mathrm{O}$, EtOH, $\mathrm{Et}_{2} \mathrm{O}$. The powder was collected and heated at $100{ }^{\circ} \mathrm{C}$ for 2-3 hours under vacuum. The dry activated $\mathrm{Zn}$ powder was stored under Ar atmosphere.

All reactions were performed in oven-dried glassware under an atmosphere of $\mathrm{Ar}$ unless otherwise noted.

Substrates a1, a2, a4, a5, a6, a11 and a16 were synthesized via Route A:

In a $25 \mathrm{~mL}$ schlenk tube equipped with a tefloncoated magnetic stir bar, the 5-bromo-1-aza-5-germabicyclo[3.3.3] undecane (1 mmol), Mg powder (3 mmol), anhydrous THF ( $5 \mathrm{~mL})$ and alkyl bromides $(2 \mathrm{mmol})$ were added and heated at $60{ }^{\circ} \mathrm{C}$ for 8 hours. Then the mixture was concentrated and extracted with petroleum ether (or EtOAc) $/ \mathrm{H}_{2} \mathrm{O}$. The organic phase was separated and dried over $\mathrm{MgSO}_{4}$ and concentrated in vacuo to afford the corresponding alkyl carbagermatranes which could be purified by silica gel column chromatography.

Substrates a3, a7, a8, a9, a10, a12, a13, a14 and a17 were synthesized via Route B:

To a $25 \mathrm{~mL}$ schlenk tube equipped with a tefloncoated magnetic stir bar, the 5-bromo-1-aza-5-germabicyclo[3.3.3] undecane $(1 \mathrm{mmol}), \mathrm{Zn}$ powder $(3 \mathrm{mmol})$, anhydrous DMF $(5 \mathrm{~mL})$ and alkyl iodides $(1.1 \mathrm{mmol})$ were added and heated at $60{ }^{\circ} \mathrm{C}$ for 8 hours. Then the mixture was extracted with petroleum ether (or EtOAc) $/ \mathrm{H}_{2} \mathrm{O}$. The organic phase was separated and dried over $\mathrm{MgSO}_{4}$ and concentrated in vacuo to afford the corresponding alkyl carbagermatranes which could be purified by silica gel column chromatography.

\subsubsection{Characterization data of alkyl carbagermatranes and chiral HPLC data}

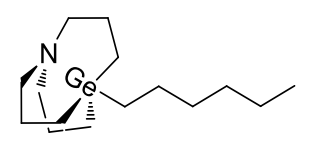

5-hexyl-1-aza-5-germabicyclo[3.3.3]undecane (a1). The general Route A for the preparation of a1 was employed on $2 \mathrm{mmol}$ scale. The reaction mixture was extracted with petroleum ether, and the crude product could be isolated by silica gel column chromatography (300-400 mesh) as colorless oil (using petroleum ether as eluent, $R_{\mathrm{f}}=0.9,95 \%, 566 \mathrm{mg}$ ). ${ }^{1} \mathbf{H}$ NMR $\left(400 \mathrm{MHz}, \mathrm{CDCl}_{3}\right) \delta 2.40(\mathrm{t}, J=6.0 \mathrm{~Hz}, 6 \mathrm{H}), 1.57-1.47(\mathrm{~m}, 6 \mathrm{H}), 1.30-1.17(\mathrm{~m}, 8 \mathrm{H})$, $0.87(\mathrm{t}, J=8.0 \mathrm{~Hz}, 3 \mathrm{H}), 0.62(\mathrm{t}, J=6.0 \mathrm{~Hz}, 6 \mathrm{H}), 0.34(\mathrm{t}, J=8.0 \mathrm{~Hz}, 2 \mathrm{H}) .{ }^{13} \mathbf{C}$ NMR $(101 \mathrm{MHz}$, $\left.\mathrm{CDCl}_{3}\right) \delta 53.8,34.0,31.9,25.6,23.6,22.9,21.6,14.4,11.7$. GC-MS (EI) Calcd for $\left[\mathrm{C}_{15} \mathrm{H}_{31}{ }^{74} \mathrm{GeN}\right]$ 298; Found: 298, 214.

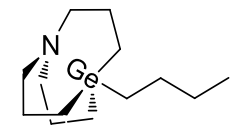

5-butyl-1-aza-5-germabicyclo[3.3.3] undecane (a2). The general Route $\mathbf{A}$ for the preparation of $\mathbf{a} 2$ was employed on 1 mmol scale. The reaction mixture was extracted with petroleum ether, and the crude product could be isolated by silica gel column chromatography (300-400 mesh) as colorless oil (using petroleum ether as eluent, $R_{\mathrm{f}}=0.9,94 \%, 254 \mathrm{mg}$ ). ${ }^{1} \mathbf{H}$ 
NMR (400 MHz, $\left.\mathbf{C}_{6} \mathbf{D}_{\mathbf{6}}\right) \delta 2.20(\mathrm{t}, J=6.0 \mathrm{~Hz}, 6 \mathrm{H}), 1.50-1.40(\mathrm{~m}, 10 \mathrm{H}), 1.00(\mathrm{t}, J=6.8 \mathrm{~Hz}, 3 \mathrm{H})$, $0.69(\mathrm{t}, J=6.4 \mathrm{~Hz}, 6 \mathrm{H}), 0.59(\mathrm{t}, J=8.0 \mathrm{~Hz}, 2 \mathrm{H}) .{ }^{13} \mathbf{C} \mathbf{N M R}\left(101 \mathrm{MHz}, \mathbf{C}_{6} \mathbf{D}_{6}\right) \delta 53.8,28.4,27.6$, 23.9, 21.7, 14.3, 11.8. GC-MS (EI) Calcd for $\left[\mathrm{C}_{13} \mathrm{H}_{27}{ }^{74} \mathrm{GeN}\right]$ 270; Found: 270, 214.

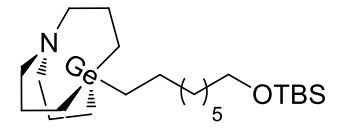

5-(8-((tert-butyldimethylsilyl)oxy)octyl)-1-aza-5-germabicyclo[3.3.3]undecane (a3). The general Route $\mathbf{B}$ for the preparation of $\mathbf{a} 3$ was employed on $1 \mathrm{mmol} \mathrm{scale}$, and the corresponding alkyl iodide was prepared according to the literature ${ }^{7}$. The product was isolated by silica gel column chromatography (300-400 mesh) as colorless oil (using petroleum ether as eluent, $R_{\mathrm{f}}=0.3$, 76\%, $347 \mathrm{mg}) .{ }^{1} \mathbf{H}$ NMR (400 MHz, $\left.\mathbf{C}_{6} \mathbf{D}_{6}\right) \delta 3.57(\mathrm{t}, J=6.4 \mathrm{~Hz}, 2 \mathrm{H}), 2.20(\mathrm{t}, J=6.0 \mathrm{~Hz}, 6 \mathrm{H})$, $1.66-1.29(\mathrm{~m}, 18 \mathrm{H}), 1.00(\mathrm{~s}, 9 \mathrm{H}), 0.71(\mathrm{t}, J=6.4 \mathrm{~Hz}, 6 \mathrm{H}), 0.60(\mathrm{t}, J=8.0 \mathrm{~Hz}, 2 \mathrm{H}), 0.08(\mathrm{~s}, 6 \mathrm{H})$. ${ }^{13} \mathbf{C}$ NMR (101 MHz, $\left.\mathbf{C}_{6} \mathbf{D}_{\mathbf{6}}\right) \delta$ 63.4, 53.9, 34.7, 33.4, 30.1, 30.0, 26.5, 26.3, 26.1, 23.9, 22.0, 18.6, 11.9, -5.1. HRMS (ESI) Calcd for $\left[\mathrm{C}_{23} \mathrm{H}_{50}{ }^{74} \mathrm{GeNOSi}\right]^{+}[\mathrm{M}+\mathrm{H}]^{+}:$458.2873; Found: 458.2855.

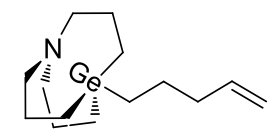

5-(pent-4-en-1-yl)-1-aza-5-germabicyclo[3.3.3]undecane (a4). The general

Route $\mathbf{A}$ for the preparation of a4 was employed on $1 \mathrm{mmol} \mathrm{scale}$. The reaction mixture was extracted with petroleum ether, and the crude product could be isolated by silica gel column chromatography (300-400 mesh) as colorless oil (using petroleum ether as eluent, $R_{\mathrm{f}}=0.9,91 \%$, $256 \mathrm{mg}) .{ }^{1} \mathbf{H}$ NMR (400 MHz, CDCl $) \delta 5.95-5.63(\mathrm{~m}, 1 \mathrm{H}), 4.94(\mathrm{dd}, J=24.0,13.7 \mathrm{~Hz}, 2 \mathrm{H})$, $2.40(\mathrm{t}, J=6.0 \mathrm{~Hz}, 6 \mathrm{H}), 2.03-1.90(\mathrm{~m}, 2 \mathrm{H}), 1.55-1.48(\mathrm{~m}, 6 \mathrm{H}), 1.42-1.30(\mathrm{~m}, 2 \mathrm{H}), 0.62(\mathrm{t}, J=$ $6.4 \mathrm{~Hz}, 6 \mathrm{H}), 0.36(\mathrm{t}, J=8.0 \mathrm{~Hz}, 2 \mathrm{H}) .{ }^{13} \mathbf{C} \mathbf{~ N M R}\left(\mathbf{1 0 1} \mathbf{~ M H z}, \mathbf{C D C l}_{3}\right) \delta 139.9,113.9,53.8,38.5$, 25.6, 23.6, 21.3, 11.6. GC-MS (EI) Calcd for $\left[\mathrm{C}_{14} \mathrm{H}_{27}{ }^{74} \mathrm{GeN}\right]$ 282; Found: 282, 214.

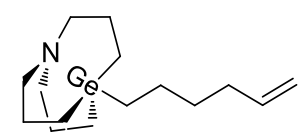

5-(hex-5-en-1-yl)-1-aza-5-germabicyclo[3.3.3] undecane (a5). The general

Route $\mathbf{A}$ for the preparation of $\mathbf{a 5}$ was employed on $1 \mathrm{mmol}$ scale. The reaction mixture was extracted with petroleum ether, and the crude product could be isolated by silica gel column chromatography (300-400 mesh) as colorless oil (using petroleum ether as eluent, $R_{f}=0.9,92 \%$, $272 \mathrm{mg}$ ). ${ }^{1} \mathbf{H}$ NMR (400 MHz, $\left.\mathbf{C}_{\mathbf{6}} \mathbf{D}_{\mathbf{6}}\right) \delta 5.87$ (ddt, $\left.J=16.9,10.2,6.7 \mathrm{~Hz}, 1 \mathrm{H}\right), 5.05$ (dd, $J=29.9$, $13.9 \mathrm{~Hz}, 2 \mathrm{H}), 2.19(\mathrm{t}, J=6.0 \mathrm{~Hz}, 6 \mathrm{H}), 2.11(\mathrm{q}, J=6.6 \mathrm{~Hz}, 2 \mathrm{H}), 1.53-1.39(\mathrm{~m}, 10 \mathrm{H}), 0.68(\mathrm{t}, J=$ $6.4 \mathrm{~Hz}, 6 \mathrm{H}), 0.54(\mathrm{t}, J=6.0 \mathrm{~Hz}, 2 \mathrm{H}) .{ }^{13} \mathbf{C}$ NMR $\left(\mathbf{1 0 1} \mathbf{~ M H z}, \mathbf{C}_{\mathbf{6}} \mathbf{D}_{6}\right) \delta 139.6,114.3,53.9,34.2,33.9$, 25.5, 23.9, 21.8, 11.9. GC-MS (EI) Calcd for $\left[\mathrm{C}_{15} \mathrm{H}_{29}{ }^{74} \mathrm{GeN}\right]$ 296; Found: 296, 214.

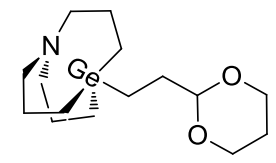

5-[2-(1,3-dioxan-2-yl)ethyl]-1-aza-5-germabicyclo[3.3.3]undecane (a6). The general Route A for the preparation of $\mathbf{a 6}$ was employed on $2 \mathrm{mmol}$ scale. The reaction mixture was extracted with petroleum ether, and the crude product could be isolated by silica gel column chromatography (300-400 mesh) as colorless oil (using petroleum ether/EtOAc $=100 / 1$ as eluent, $\left.\mathrm{R}_{\mathrm{f}}=0.4,92 \% .603 \mathrm{mg}\right){ }^{1} \mathbf{H}$ NMR (400 MHz, $\left.\mathbf{C D C l}_{3}\right) \delta 4.38(\mathrm{t}, J=5.2 \mathrm{~Hz}, 1 \mathrm{H}), 4.13-4.08(\mathrm{~m}$, $2 \mathrm{H}), 3.80-3.73(\mathrm{~m}, 2 \mathrm{H}), 2.39(\mathrm{t}, J=6.0 \mathrm{~Hz}, 6 \mathrm{H}), 2.16-1.98(\mathrm{~m}, 1 \mathrm{H}), 1.61-1.44(\mathrm{~m}, 8 \mathrm{H}), 1.38$ $-1.27(\mathrm{~m}, 1 \mathrm{H}), 0.63(\mathrm{t}, J=6.4 \mathrm{~Hz}, 6 \mathrm{H}), 0.42-0.30(\mathrm{~m}, 2 \mathrm{H}) .{ }^{13} \mathbf{C}$ NMR $\left(\mathbf{1 0 1} \mathbf{~ M H z}, \mathbf{C D C l}_{3}\right) \delta$ 
105.2, 67.1, 53.8, 31.3, 26.1, 23.5, 14.9, 11.5. HRMS (ESI) Calcd for $\left[\mathrm{C}_{15} \mathrm{H}_{30}{ }^{74} \mathrm{GeNO}_{2}\right]^{+}[\mathrm{M}+\mathrm{H}]^{+}$: 330.1488; Found: 330.1489 .<smiles>N#CCCCCC12C[C@@H]1N1CCCOC2CC1</smiles>

5-(1-aza-5-germabicyclo[3.3.3] undecan-5-yl)pentanenitrile $\quad$ (a7). The general Route B for the preparation of a7 was employed on $1 \mathrm{mmol}$ scale. The reaction mixture was extracted with petroleum ether, and the crude product could be isolated by silica gel column chromatography (300-400 mesh) as colorless oil (using petroleum ether/EtOAc $=50 / 1$ as eluent, $\left.\mathrm{R}_{\mathrm{f}}=0.6,88 \%, 259 \mathrm{mg}\right) .{ }^{1} \mathbf{H}$ NMR $\left(400 \mathrm{MHz}, \mathbf{C}_{6} \mathbf{D}_{6}\right) \delta 2.16(\mathrm{t}, J=6.0 \mathrm{~Hz}, 6 \mathrm{H}), 1.59-1.47(\mathrm{~m}$, 2H), $1.47-1.35(\mathrm{~m}, 6 \mathrm{H}), 1.30-1.05(\mathrm{~m}, 4 \mathrm{H}), 0.59$ (t, $J=6.4 \mathrm{~Hz}, 6 \mathrm{H}), 0.22(\mathrm{t}, J=8.0 \mathrm{~Hz}, 2 \mathrm{H})$. ${ }^{13} \mathbf{C}$ NMR (101 MHz, $\left.\mathbf{C}_{6} \mathbf{D}_{6}\right) \delta 119.7,53.8,29.6,24.8,23.7,20.7,16.3,11.8$. HRMS (ESI) Calcd for $\left[\mathrm{C}_{14} \mathrm{H}_{27}{ }^{74} \mathrm{GeNO}_{2}\right]^{+}[\mathrm{M}+\mathrm{H}]^{+}:$297.1386; Found: 297.1386 .<smiles>O=C1c2ccccc2C(=O)N1CCCCC12CC3CCCN(CC3)C1C2</smiles>

2-(4-(1-aza-5-germabicyclo[3.3.3] undecan-5-yl)butyl)isoindoline-1,3-dione (a8). The general Route $\mathbf{B}$ for the preparation of $\mathbf{a 8}$ was employed on $1 \mathrm{mmol} \mathrm{scale}$, the product was isolated by silica gel column chromatography (300-400 mesh) as white solid (using petroleum ether/EtOAc $=$ 4/1 as eluent, $\left.\mathrm{R}_{\mathrm{f}}=0.6,87 \%, 360 \mathrm{mg}\right) .{ }^{1} \mathbf{H} \mathbf{~ N M R}\left(\mathbf{4 0 0} \mathbf{~ M H z}, \mathbf{C D C l}_{\mathbf{3}}\right) \delta 7.82-7.85(\mathrm{~m}, 2 \mathrm{H}), 7.75-$ $7.67(\mathrm{~m}, 2 \mathrm{H}), 3.65(\mathrm{t}, J=8.0 \mathrm{~Hz}, 2 \mathrm{H}), 2.39(\mathrm{t}, J=6.0 \mathrm{~Hz}, 6 \mathrm{H}), 1.67-1.58(\mathrm{~m}, 2 \mathrm{H}), 1.56-1.46$ $(\mathrm{m}, 6 \mathrm{H}), 1.38-1.27(\mathrm{~m}, 2 \mathrm{H}), 0.61(\mathrm{t}, J=6.0 \mathrm{~Hz}, 6 \mathrm{H}), 0.36(\mathrm{t}, J=10.0 \mathrm{~Hz}, 2 \mathrm{H}) .{ }^{13} \mathbf{C}$ NMR $(101$ MHz, $\left.\mathbf{C D C l}_{3}\right) \delta 168.6,133.9,132.4,123.2,53.8,38.1,32.9,23.5,23.0,21.1,11.6$. HRMS (ESI) Calcd for $\left[\mathrm{C}_{21} \mathrm{H}_{31}{ }^{74} \mathrm{GeN}_{2} \mathrm{O}_{2}\right]^{+}[\mathrm{M}+\mathrm{H}]^{+}: 417.1597$; Found: 417.1602 .

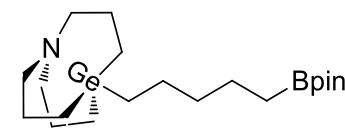

5-(5-(4,4,5,5-tetramethyl-1,3,2-dioxaborolan-2-yl)pentyl)-1-aza-5-germabicyclo[3.3.3] undeca ne (a9). The general Route $\mathbf{B}$ for the preparation of a9 was employed on $1 \mathrm{mmol} \mathrm{scale}$, the product was isolated by silica gel column chromatography (300-400 mesh) as colorless oil (using petroleum ether/EtOAc $=50 / 1$ as eluent, $\left.\mathbf{R}_{\mathrm{f}}=0.4,88 \%, 360 \mathrm{mg}\right) .{ }^{1} \mathbf{H} \mathbf{~ N M R}\left(\mathbf{4 0 0} \mathbf{M H z}, \mathbf{C}_{\mathbf{6}} \mathbf{D}_{\mathbf{6}}\right) \delta$ $2.20(\mathrm{t}, J=6.0 \mathrm{~Hz}, 6 \mathrm{H}), 1.76-1.70(\mathrm{~m}, 2 \mathrm{H}), 1.60-1.49(\mathrm{~m}, 4 \mathrm{H}), 1.47-1.39(\mathrm{~m}, 6 \mathrm{H}), 1.10-$ $1.05(\mathrm{~m}, 14 \mathrm{H}), 0.67(\mathrm{t}, J=6.4 \mathrm{~Hz}, 6 \mathrm{H}), 0.59(\mathrm{t}, J=8.0 \mathrm{~Hz}, 2 \mathrm{H}) .{ }^{13} \mathbf{C} \mathbf{~ N M R}\left(\mathbf{1 0 1} \mathbf{~ M H z}, \mathbf{C}_{\mathbf{6}} \mathbf{D}_{\mathbf{6}}\right) \delta$

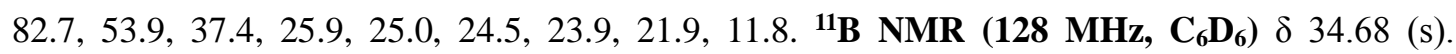
HRMS (ESI) Calcd for $\left[\mathrm{C}_{20} \mathrm{H}_{41} \mathrm{~B}^{74} \mathrm{GeNO}_{2}\right]^{+}[\mathrm{M}+\mathrm{H}]^{+}: 412.2442$; Found: 412.2445 .

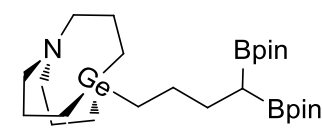

5-(4,4-bis(4,4,5,5-tetramethyl-1,3,2-dioxaborolan-2-yl)butyl)-1-aza-5-germabicyclo[3.3.3] und ecane (a10). The general Route B for the preparation of a10 was employed on $1 \mathrm{mmol}$ scale, the product was isolated by silica gel column chromatography as colorless oil (using petroleum ether/EtOAc $=30 / 1$ as eluent, $\left.\mathbf{R}_{\mathrm{f}}=0.5,76 \%, 397 \mathrm{mg}\right) .{ }^{\mathbf{1}} \mathbf{H} \mathbf{N M R}\left(\mathbf{4 0 0} \mathbf{M H z}, \mathbf{C}_{\mathbf{6}} \mathbf{D}_{\mathbf{6}}\right) \delta 2.19(\mathrm{t}, J=$ $6.0 \mathrm{~Hz}, 6 \mathrm{H}), 2.05(\mathrm{dd}, J=15.3,7.7 \mathrm{~Hz}, 2 \mathrm{H}), 1.72-1.58(\mathrm{~m}, 2 \mathrm{H}), 1.49-1.37(\mathrm{~m}, 6 \mathrm{H}), 1.21(\mathrm{t}, J=$ $7.7 \mathrm{~Hz}, 1 \mathrm{H}), 1.14(\mathrm{~d}, J=4.9 \mathrm{~Hz}, 24 \mathrm{H}), 0.74-0.61(\mathrm{~m}, 8 \mathrm{H}) .{ }^{13} \mathbf{C} \mathbf{N M R}\left(\mathbf{1 0 1} \mathbf{~ M H z}, \mathbf{C}_{6} \mathbf{D}_{6}\right) \delta 82.7$, 
53.9, 31.0, 29.2, 25.1, 24.8, 23.9, 22.1, 11.8. ${ }^{11} \mathbf{B}$ NMR (128 MHz, $\left.\mathbf{C}_{6} \mathbf{D}_{\mathbf{6}}\right) \delta 33.80$ (s). HRMS (ESI) Calcd for $\left[\mathrm{C}_{25} \mathrm{H}_{49}{ }^{74} \mathrm{GeB}_{2} \mathrm{NO}_{4} \mathrm{Na}\right]^{+}[\mathrm{M}+\mathrm{Na}]^{+}:$546.2957; Found: 546.2982.

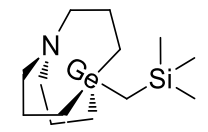

5-((trimethylsilyl)methyl)-1-aza-5-germabicyclo[3.3.3]undecane (a11). The

general Route A for the preparation of a11 was employed on $1 \mathrm{mmol} \mathrm{scale}$. The reaction mixture was extracted with petroleum ether, and the crude product could be isolated by silica gel column chromatography (300-400 mesh) as colorless oil (using petroleum ether as eluent, $R_{\mathrm{f}}=0.9,98 \%$, $294 \mathrm{mg}$ ). ${ }^{1} \mathbf{H}$ NMR (400 MHz, $\left.\mathbf{C}_{\mathbf{6}} \mathbf{D}_{\mathbf{6}}\right) \delta 2.17$ (t, $\left.J=6.0 \mathrm{~Hz}, 6 \mathrm{H}\right), 1.52-1.32(\mathrm{~m}, 6 \mathrm{H}), 0.73$ (t, $J=$ $6.4 \mathrm{~Hz}, 6 \mathrm{H}), 0.17$ (s, 9H), -0.30 (s, 2H). ${ }^{13} \mathbf{C}$ NMR (101 MHz, $\left.\mathbf{C}_{6} \mathbf{D}_{6}\right) \delta$ 53.9, 24.0, 15.6, 8.8, 2.3. GC-MS (EI) Calcd for $\left[\mathrm{C}_{13} \mathrm{H}_{29}{ }^{74} \mathrm{GeNSi}\right]$ 300; Found: 300, 214.

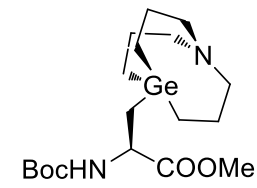

(R)-methyl

3-(1-aza-5-germabicyclo[3.3.3]undecan-5-yl)-2-((tert-butoxycarbonyl)amino)pro-panoate

(a12). The general Route B for the preparation of $\mathbf{a 1 2}$ was employed on $1 \mathrm{mmol} \mathrm{scale}$, the product was isolated by silica gel column chromatography (300-400 mesh) as colorless oil (using petroleum ether/EtOAc $=15 / 1$ as eluent, $\left.\mathrm{R}_{\mathrm{f}}=0.3,86 \%, 356 \mathrm{mg}\right) .{ }^{1} \mathbf{H} \mathbf{~ N M R}\left(\mathbf{4 0 0} \mathbf{~ M H z}, \mathbf{C D C l}_{3}\right) \delta$ $4.80(\mathrm{~d}, J=8.4 \mathrm{~Hz}, 1 \mathrm{H}), 4.24(\mathrm{dd}, J=15.3,9.1 \mathrm{~Hz}, 1 \mathrm{H}), 3.69$ (s, 3H), $2.48-2.32(\mathrm{~m}, 6 \mathrm{H}), 1.60-$ $1.48(\mathrm{~m}, 6 \mathrm{H}), 1.43(\mathrm{~s}, 9 \mathrm{H}), 0.82(\mathrm{dd}, J=13.4,6.1 \mathrm{~Hz}, 1 \mathrm{H}), 0.64-0.72(\mathrm{~m}, 7 \mathrm{H}) .{ }^{13} \mathbf{C}$ NMR $(101$ MHz, D $\mathbf{6}_{\text {-Acetone) } \delta} 176.0,156.0,79.1,54.5,52.8,52.0,28.8,26.0,24.1,13.1$. HRMS (ESI) Calcd for $\left[\mathrm{C}_{18} \mathrm{H}_{34} \mathrm{GeN}_{2} \mathrm{O}_{4} \mathrm{Na}\right]^{+}[\mathrm{M}+\mathrm{Na}]^{+}: 439.1628$; Found: 439.1632 .

\begin{tabular}{ll}
\hline Column & CHIRALCEL AD-H(ADHOCE-TD152) \\
\hline Column size & $0.46 \mathrm{~cm} \mathrm{I.D.} \times 25 \mathrm{~cm} \mathrm{~L}$ \\
Injection & $2.5 \mathrm{uL}$ \\
Mobile phase & Hexane/Isopropanol = 80/20 (V/V) \\
Flow rate & $1.0 \mathrm{~mL} / \mathrm{min}$ \\
Wave length & $\mathrm{UV} 220 \mathrm{~nm}$ \\
Temperature & $25^{\circ} \mathrm{C}$ \\
\hline
\end{tabular}




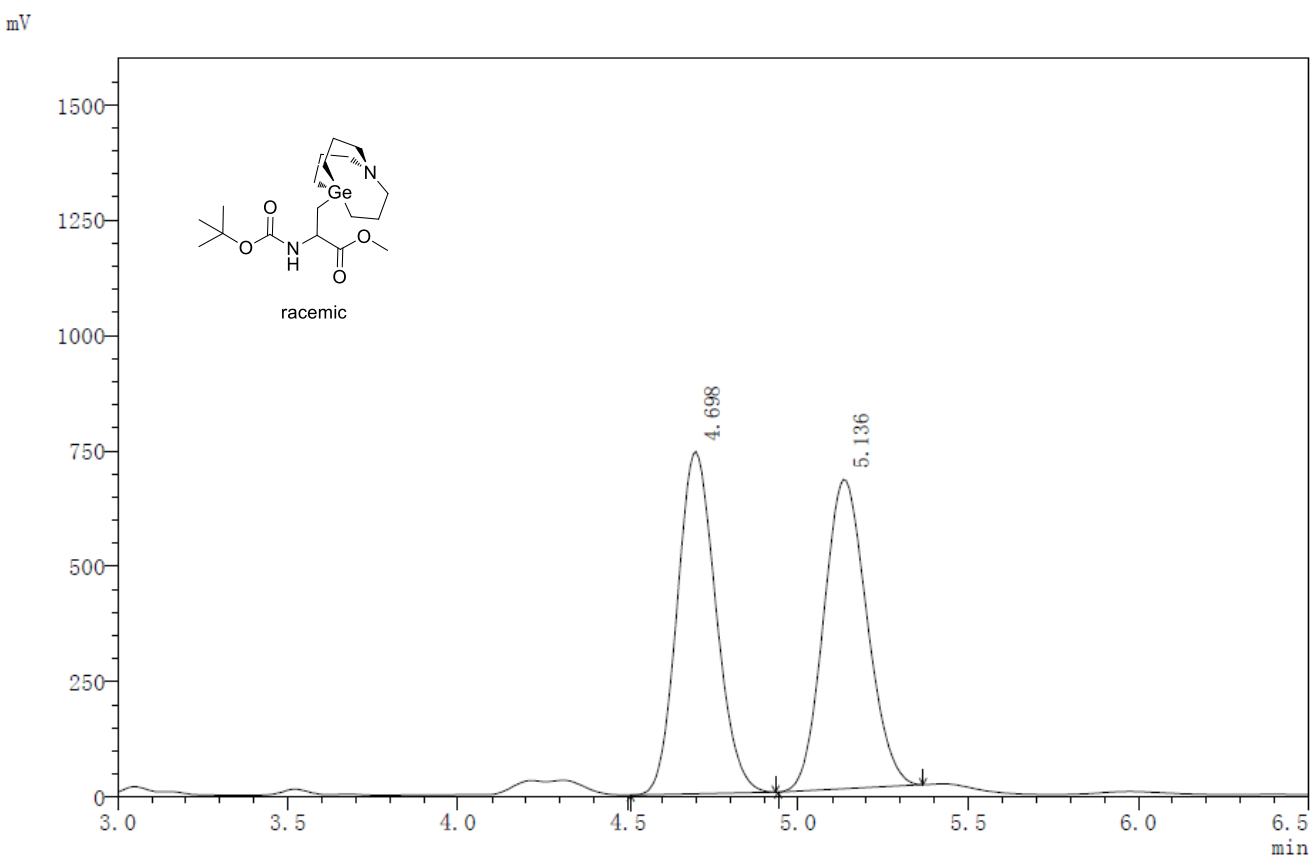

\begin{tabular}{|c|c|c|c|c|c|c|}
\hline Peak\# & Ret. Time & Area & Area\% & T.Plate\# & Tailing F. & Height \\
\hline 1 & 4.698 & 5867928 & 49.665 & 7336 & 1.129 & 740866 \\
\hline 2 & 5.136 & 5947144 & 50.335 & 7027 & 1.110 & 669949 \\
\hline
\end{tabular}

mV

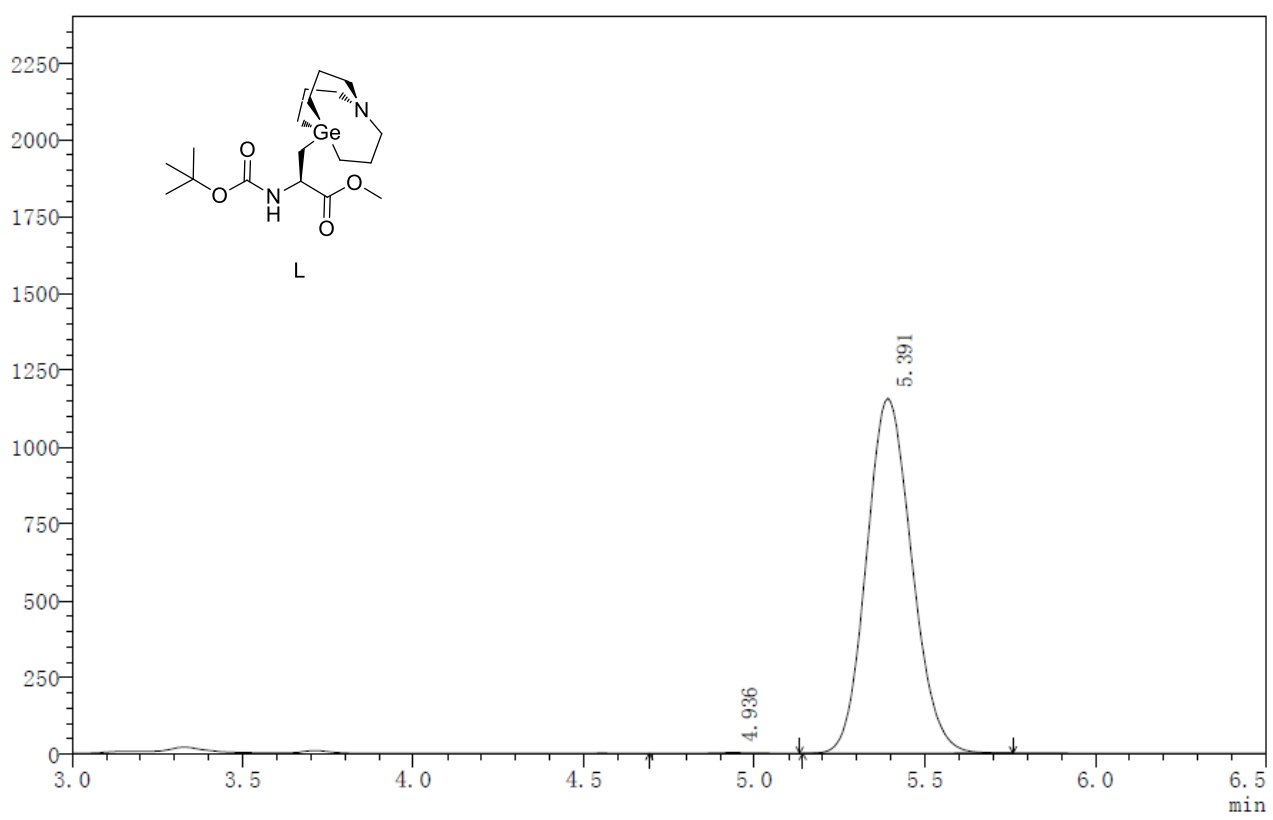

\begin{tabular}{|c|c|c|c|c|c|c|}
\hline Peak\# & Ret. Time & Area & Area\% & T.Plate\# & Tailing F. & Height \\
\hline 1 & 4.936 & 18400 & 0.172 & 6718 & 0.928 & 1913 \\
\hline 2 & 5.391 & 10672145 & 99.828 & 7294 & 1.120 & 1155152 \\
\hline
\end{tabular}


CbzHN

(R)-benzyl

2-(((benzyloxy)carbonyl)amino)-3-(1-aza-5-germabicyclo[3.3.3] undecan-5-yl)propanoate

(a13). The general Route B for the preparation of $\mathbf{a 1 3}$ was employed on $1 \mathrm{mmol}$ scale, the product was isolated by silica gel column chromatography (300-400 mesh) as colorless oil (using petroleum ether/EtOAc $=10 / 1$ as eluent, $\left.\mathbf{R}_{\mathrm{f}}=0.4,85 \%, 446 \mathrm{mg}\right){ }^{1} \mathbf{H} \mathbf{~ N M R}\left(\mathbf{4 0 0} \mathbf{~ M H z}, \mathbf{C D C l}_{3}\right) \delta$ $7.38-7.27(\mathrm{~m}, 10 \mathrm{H}), 5.21-4.96(\mathrm{~m}, 5 \mathrm{H}), 4.37(\mathrm{dd}, J=14.9,9.1 \mathrm{~Hz}, 1 \mathrm{H}), 2.45-2.25(\mathrm{~m}, 6 \mathrm{H})$, $1.55-1.40(\mathrm{~m}, 6 \mathrm{H}), 0.88(\mathrm{dd}, J=13.6,5.7 \mathrm{~Hz}, 1 \mathrm{H}), 0.75-0.58(\mathrm{~m}, 7 \mathrm{H}) .{ }^{13} \mathbf{C}$ NMR $(\mathbf{1 0 1} \mathbf{~ M H z}$, $\left.\mathbf{C D C l}_{3}\right) \delta 174.9,155.7,136.7,135.8,128.6-128.1$ (m, 10C), 66.8, 66.8, 53.7, 52.8, 25.7, 23.2, 12.6. HRMS (ESI) Calcd for $\left[\mathrm{C}_{27} \mathrm{H}_{36} \mathrm{GeN}_{2} \mathrm{O}_{4} \mathrm{Na}\right]^{+}[\mathrm{M}+\mathrm{Na}]^{+}: 549.1785$; Found: 549.1793 .

\begin{tabular}{ll}
\hline Column & CHIRALCEL AD-H(ADH0CE-TD152) \\
\hline Column size & $0.46 \mathrm{~cm} \mathrm{I.D.} \times 25 \mathrm{~cm} \mathrm{~L}$ \\
Injection & $2.5 \mathrm{uL}$ \\
Mobile phase & Hexane/Isopropanol $=80 / 20(\mathrm{~V} / \mathrm{V})$ \\
Flow rate & $1.0 \mathrm{~mL} / \mathrm{min}$ \\
Wave length & UV $220 \mathrm{~nm}$ \\
Temperature & $25^{\circ} \mathrm{C}$ \\
\hline
\end{tabular}

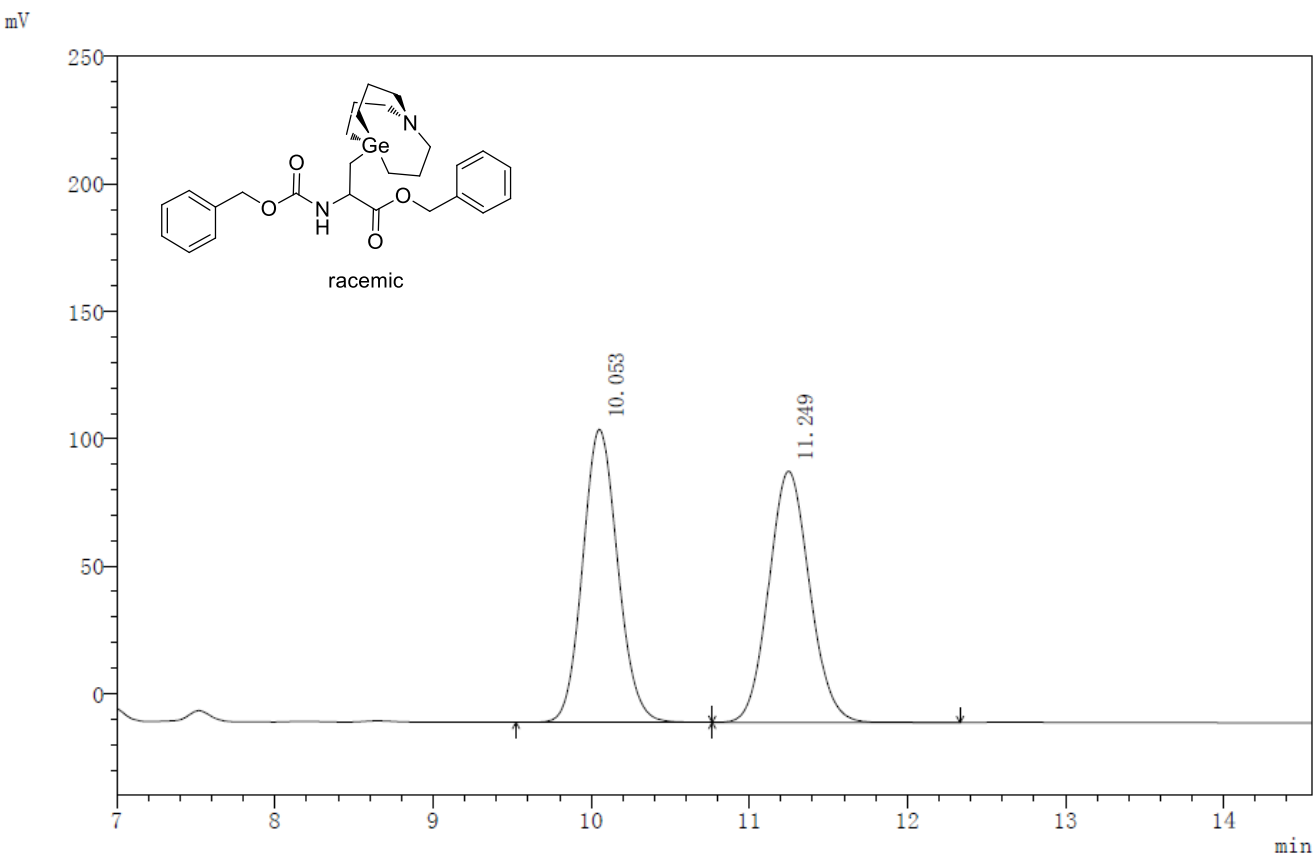

\begin{tabular}{|c|c|c|c|c|c|c|}
\hline Peak\# & Ret. Time & Area & Area\% & T.Plate\# & Tailing F. & Height \\
\hline 1 & 10.053 & 1774349 & 49.944 & 9599 & 1.101 & 114907 \\
\hline 2 & 11.249 & 1778297 & 50.056 & 8816 & 1.087 & 98651 \\
\hline
\end{tabular}




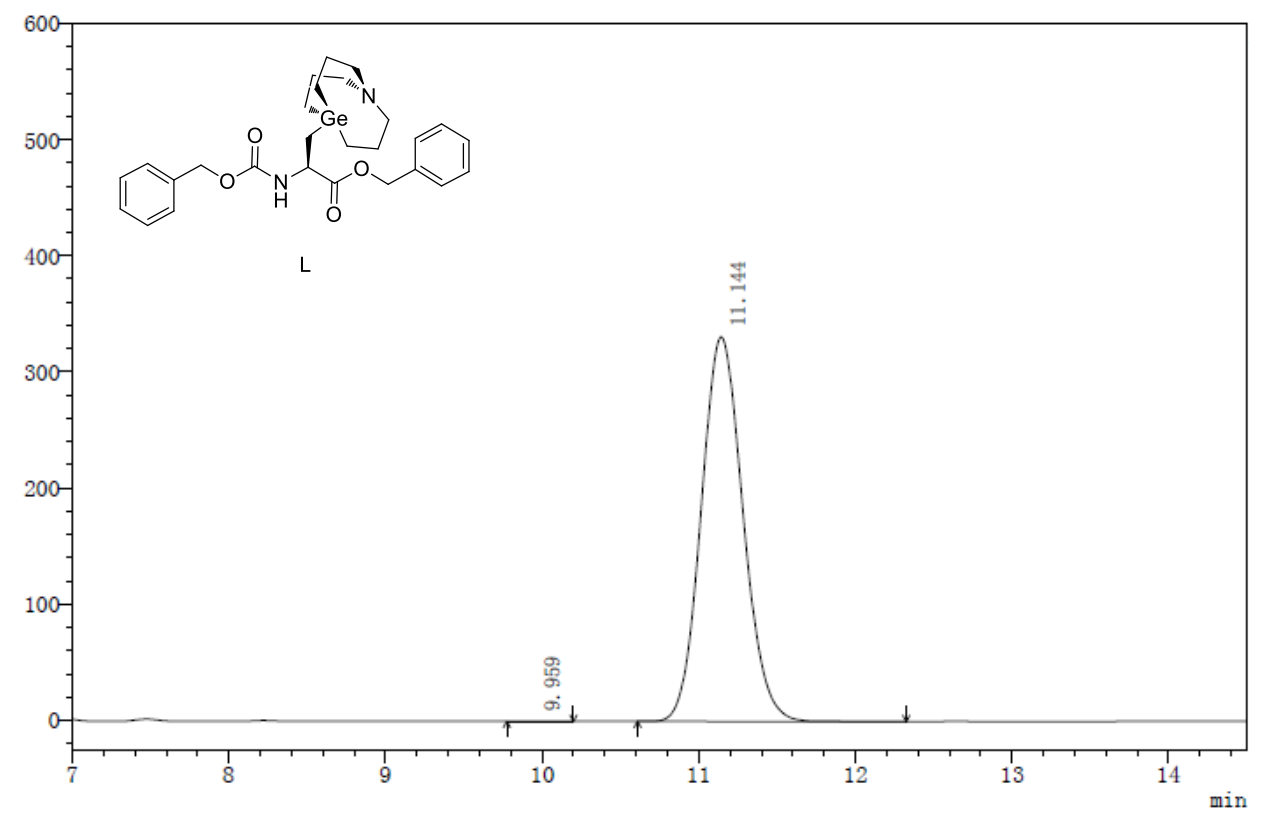

\begin{tabular}{|c|c|c|c|c|c|c|}
\hline Peak\# & Ret. Time & Area & Area\% & T.Plate\# & Tailing F. & Height \\
\hline 1 & 9.959 & 1673 & 0.027 & 14789 & 1.099 & 145 \\
\hline 2 & 11.144 & 6142614 & 99.973 & 8193 & 1.104 & 330972 \\
\hline
\end{tabular}

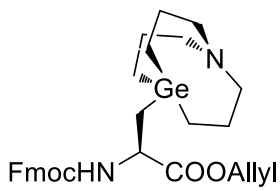

(R)-allyl

2-((((9H-fluoren-9-yl)methoxy)carbonyl)amino)-3-(1-aza-5-germabicyclo[3.3.3]undecan-5-yl) propanoate (a14). The general Route B for the preparation of a14 was employed on $1 \mathrm{mmol}$ scale, the product was isolated by silica gel column chromatography (300-400 mesh) as colorless oil (using petroleum ether/EtOAc $=5 / 1$ as eluent, $\left.R_{\mathrm{f}}=0.4,83 \%, 467 \mathrm{mg}\right) .{ }^{1} \mathbf{H}$ NMR $(400 \mathrm{MHz}$, $\left.\mathbf{C D C l}_{3}\right) \delta 7.75(\mathrm{~d}, J=7.5 \mathrm{~Hz}, 2 \mathrm{H}), 7.63-7.59(\mathrm{~m}, 2 \mathrm{H}), 7.41-7.36(\mathrm{~m}, 2 \mathrm{H}), 7.32-7.27(\mathrm{~m}, 2 \mathrm{H})$, $5.97-5.86(\mathrm{~m}, 1 \mathrm{H}), 5.33(\mathrm{dd}, J=17.2,1.4 \mathrm{~Hz}, 1 \mathrm{H}), 5.23(\mathrm{dd}, J=10.4,1.1 \mathrm{~Hz}, 1 \mathrm{H}), 5.08(\mathrm{~d}, J=$ $8.6 \mathrm{~Hz}, 1 \mathrm{H}), 4.55-4.66(\mathrm{~m}, 2 \mathrm{H}), 4.45-4.28(\mathrm{~m}, 3 \mathrm{H}), 4.23(\mathrm{t}, J=7.2 \mathrm{~Hz}, 1 \mathrm{H}), 2.47-2.30(\mathrm{~m}, 6 \mathrm{H})$, $1.62-1.44(\mathrm{~m}, 6 \mathrm{H}), 0.91(\mathrm{dd}, J=13.5,5.6 \mathrm{~Hz}, 1 \mathrm{H}), 0.80-0.65(\mathrm{~m}, 7 \mathrm{H}) .{ }^{13} \mathbf{C} \mathbf{~ N M R}(\mathbf{1 0 1} \mathbf{~ M H z}$, $\left.\mathbf{C D C l}_{3}\right) \delta 174.8,155.8,144.1,141.4,132.1,127.8,127.2,125.3,125.2,120.1,118.5,67.0,65.7$, 53.8, 52.7, 47.3, 25.7, 23.3, 12.7. HRMS (ESI) Calcd for $\left[\mathrm{C}_{30} \mathrm{H}_{38} \mathrm{GeN}_{2} \mathrm{O}_{4} \mathrm{Na}\right]^{+}[\mathrm{M}+\mathrm{Na}]^{+}$: 587.1950; Found: 587.1941.

\begin{tabular}{ll}
\hline Column & CHIRALCEL AD-H(ADH0CE-TD152) \\
\hline Column size & $0.46 \mathrm{~cm} \mathrm{I.D.} \times 25 \mathrm{~cm} \mathrm{~L}$ \\
Injection & $2.5 \mathrm{uL}$ \\
Mobile phase & Hexane/Isopropanol = 70/30 $(\mathrm{V} / \mathrm{V})$ \\
Flow rate & $0.6 \mathrm{~mL} / \mathrm{min}$ \\
Wave length & UV $254 \mathrm{~nm}$ \\
Temperature & $25^{\circ} \mathrm{C}$ \\
\hline
\end{tabular}




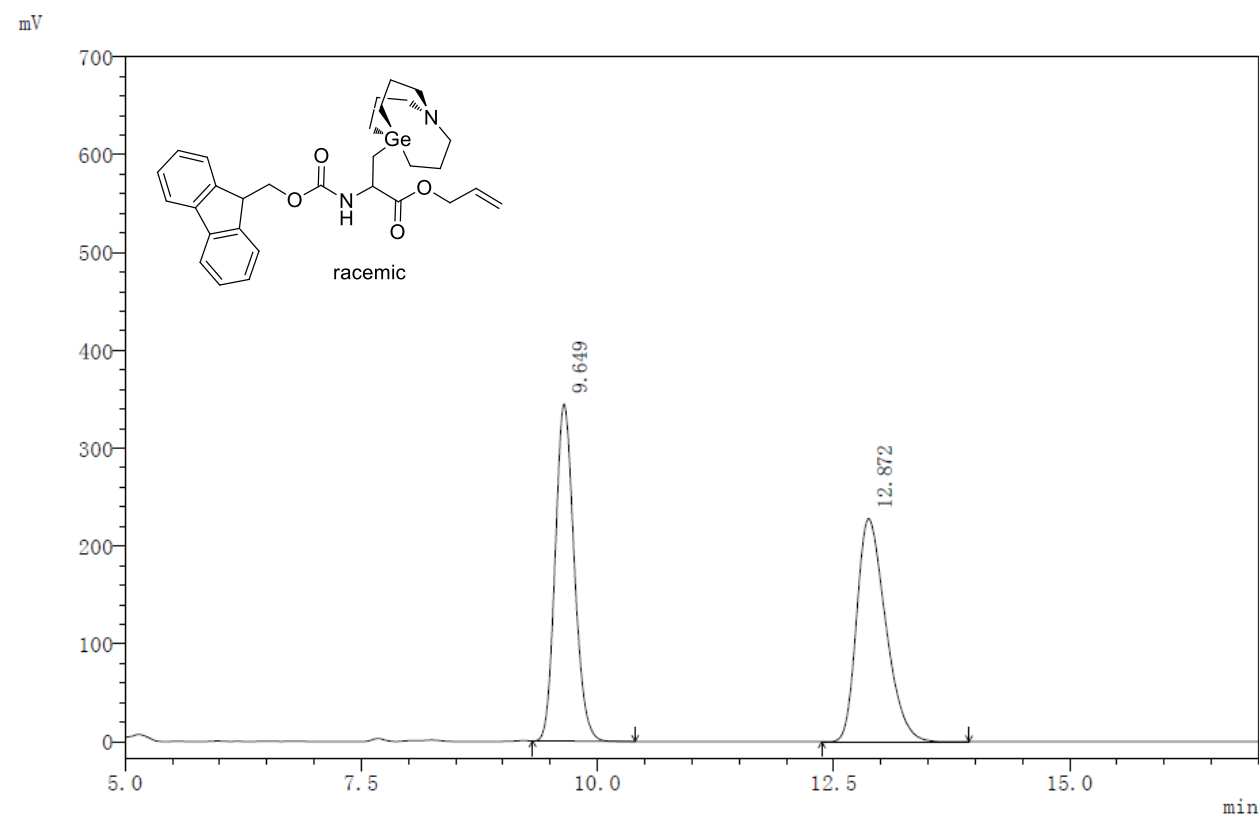

\begin{tabular}{|c|c|c|c|c|c|c|}
\hline Peak\# & Ret. Time & Area & Area\% & T.Plate\# & Tailing F. & Height \\
\hline 1 & 9.649 & 4819852 & 49.756 & 10708 & 1.153 & 344518 \\
\hline 2 & 12.872 & 4867046 & 50.244 & 8296 & 1.345 & 228003 \\
\hline
\end{tabular}

$\mathrm{mV}$

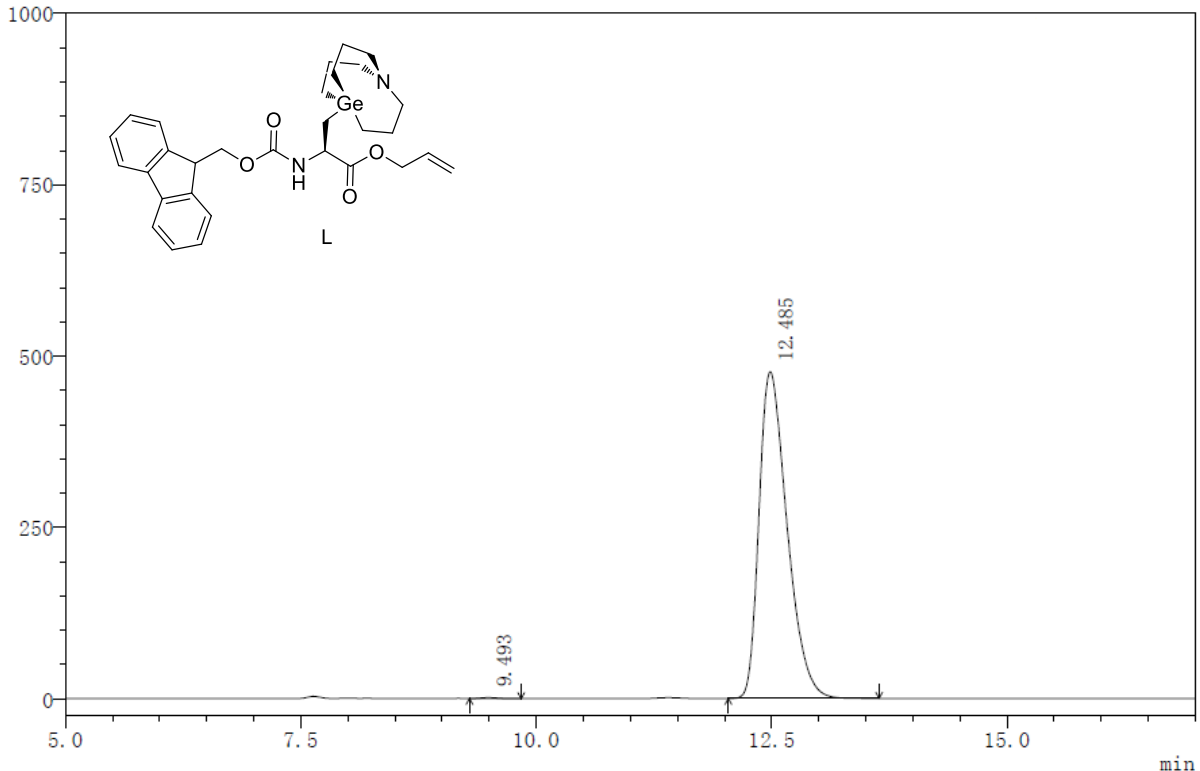

\begin{tabular}{|c|c|c|c|c|c|c|}
\hline Peak\# & Ret. Time & Area & Area\% & T.Plate\# & Tailing F. & Height \\
\hline 1 & 9.493 & 16906 & 0.171 & 12005 & 1.206 & 1336 \\
\hline 2 & 12.485 & 9885036 & 99.829 & 8315 & 1.437 & 476492 \\
\hline
\end{tabular}


5-cyclopropyl-1-aza-5-germabicyclo[3.3.3] undecane (a16). The general Route A for the preparation of a16 was employed on $1 \mathrm{mmol}$ scale. The reaction mixture was extracted with petroleum ether, and the crude product could be isolated by silica gel column chromatography (300-400 mesh) as colorless oil (using petroleum ether as eluent, $R_{f}=0.9,90 \%$, $227 \mathrm{mg}) .{ }^{1} \mathbf{H}$ NMR (400 MHz, $\left.\mathbf{C}_{6} \mathbf{D}_{\mathbf{6}}\right) \delta 2.13(\mathrm{t}, J=6.0 \mathrm{~Hz}, 6 \mathrm{H}), 1.47-1.28(\mathrm{~m}, 6 \mathrm{H}), 0.74-0.57$ $(\mathrm{m}, 8 \mathrm{H}), 0.34-0.20(\mathrm{~m}, 2 \mathrm{H}),-0.27(\mathrm{tt}, J=9.7,6.8 \mathrm{~Hz}, 1 \mathrm{H}) .{ }^{13} \mathbf{C} \mathbf{N M R}\left(\mathbf{1 0 1} \mathbf{M H z}, \mathbf{C}_{6} \mathbf{D}_{6}\right) \delta 53.8$, 23.7, 10.6, 2.1, 1.1. GC-MS (EI) Calcd for $\left[\mathrm{C}_{12} \mathrm{H}_{23}{ }^{74} \mathrm{GeN}\right]$ 254; Found: 254, 214.

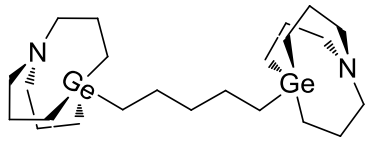

1,5-di(1-aza-5-germabicyclo[3.3.3] undecan-5-yl)pentane (a17). To a $25 \mathrm{~mL}$ schlenk tube equipped with a tefloncoated magnetic stir bar, the 5-bromo-1-aza-5-germabicyclo[3.3.3] undecane $(2 \mathrm{mmol}), \mathrm{Zn}$ powder $(6 \mathrm{mmol})$, anhydrous DMF $(10 \mathrm{~mL})$ and 1,5 -diiodopentane $(1.0 \mathrm{mmol})$ were added and heated at $60{ }^{\circ} \mathrm{C}$ for 8 hours. Then the mixture was extracted with petroleum ether $/ \mathrm{H}_{2} \mathrm{O}$. The organic phase was separated and dried over $\mathrm{MgSO}_{4}$ and concentrated in vacuo. The crude product could be isolated by silica gel column chromatography (300-400 mesh) as colorless oil (using petroleum ether as eluent, $R_{f}=0.9,81 \%$, $396 \mathrm{mg}$ ). Small amount of 5-pentyl-1-aza-5-germabicyclo[3.3.3]undecane was detected in NMR spectrogram. ${ }^{1} \mathbf{H}$ NMR (400 MHz, $\left.\mathbf{C}_{6} \mathbf{D}_{\mathbf{6}}\right) \delta 2.20$ (t, $\left.J=6.0 \mathrm{~Hz}, 12 \mathrm{H}\right), 1.64-1.55$ (m, 4H), $1.52-$ $1.36(\mathrm{~m}, 14 \mathrm{H}), 0.78-0.63(\mathrm{~m}, 16 \mathrm{H}) .{ }^{13} \mathbf{C}$ NMR (101 MHz, $\left.\mathbf{C}_{6} \mathbf{D}_{6}\right) \delta 53.9,39.3,26.0,23.9,22.1$, 11.9 .

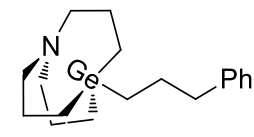

5-(3-phenylpropyl)-1-aza-5-germabicyclo[3.3.3]undecane. The general Route

A for the preparation of 5-(3-phenylpropyl)-1-aza-5-germabicyclo[3.3.3] undecane was employed on $1 \mathrm{mmol}$ scale. The reaction mixture was extracted with petroleum ether, and the crude product could be isolated by silica gel column chromatography (300-400 mesh) as colorless oil (using petroleum ether as eluent, $\left.\mathbf{R}_{\mathrm{f}}=0.7,90 \%, 299 \mathrm{mg}\right) .{ }^{1} \mathbf{H} \mathbf{~ N M R}\left(\mathbf{4 0 0} \mathbf{~ M H z}, \mathbf{C}_{\mathbf{6}} \mathbf{D}_{\mathbf{6}}\right) \delta 7.24-$ $7.14(\mathrm{~m}, 4 \mathrm{H}), 7.12-7.05(\mathrm{~m}, 1 \mathrm{H}), 2.64(\mathrm{t}, J=7.6 \mathrm{~Hz}, 2 \mathrm{H}), 2.17(\mathrm{t}, J=6.0 \mathrm{~Hz}, 6 \mathrm{H}), 1.78-1.64$ $(\mathrm{m}, 2 \mathrm{H}), 1.47-1.34(\mathrm{~m}, 6 \mathrm{H}), 0.63(\mathrm{t}, J=6.4 \mathrm{~Hz}, 6 \mathrm{H}), 0.60-0.53(\mathrm{~m}, 2 \mathrm{H}) .{ }^{13} \mathbf{C}$ NMR (101 MHz, $\left.\mathbf{C}_{6} \mathbf{D}_{6}\right) \delta 143.6,128.9,128.6,125.9,53.8,41.1,28.5,23.8,21.8,11.8$. GC-MS (EI) Calcd for $\left[\mathrm{C}_{18} \mathrm{H}_{29}{ }^{74} \mathrm{GeN}\right] 332$; Found: 332, 214.

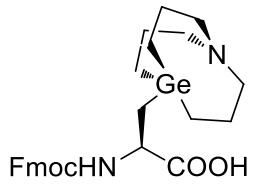

(R)-2-((((9H-fluoren-9-yl)methoxy)carbonyl)amino)-3-(1-aza-5-germabicyclo[3.3.3]undecan5-yl)propanoic acid (a24). To a solution of compound a14 $(0.83 \mathrm{mmol})$ in $\mathrm{CH}_{2} \mathrm{Cl}_{2}$ at room temperature was added morpholine $(1.66 \mathrm{mmol})$ and $\mathrm{Pd}\left(\mathrm{PPh}_{3}\right)_{4}(0.02 \mathrm{mmol})$ in an atmosphere of $\mathrm{Ar}$, and the mixture was stirred at $\mathrm{rt}$ for 10 minutes and adjusted to $\mathrm{pH} 2$ with diluted hydrochloric acid $(1 \mathrm{M})$ and extracted with EtOAc $(50 \mathrm{~mL})$. The combined organic layers were dried over $\mathrm{Na}_{2} \mathrm{SO}_{4}$ and concentrated in vacuo to give the compound without further purification as white solid (the reaction processing could be monitored by TLC using petroleum ether/EtOAc $=1 / 2$ as 
eluent, $\left.\mathrm{R}_{\mathrm{f}}=0.2,98 \%, 423 \mathrm{mg}\right) .{ }^{1} \mathbf{H}$ NMR (400 MHz, $\mathbf{D}_{\mathbf{6}}$-Acetone) $\delta 7.85(\mathrm{~d}, J=7.5 \mathrm{~Hz}, 2 \mathrm{H}), 7.76$ $-7.72(\mathrm{~m}, 2 \mathrm{H}), 7.43-7.39(\mathrm{~m}, 2 \mathrm{H}), 7.35-7.30(\mathrm{~m}, 2 \mathrm{H}), 6.41(\mathrm{~d}, J=8.7 \mathrm{~Hz}, 1 \mathrm{H}), 4.42-4.17(\mathrm{~m}$, 4H), $2.53-2.32(\mathrm{~m}, 6 \mathrm{H}), 1.64-1.48(\mathrm{~m}, 6 \mathrm{H}), 1.02-0.64(\mathrm{~m}, 8 \mathrm{H}) .{ }^{13} \mathbf{C}$ NMR (101 MHz, D6-Acetone) $\delta 176.3,156.6,145.2,145.0,142.0,128.5,127.9,126.2,126.2,120.7,67.1,54.3$, 52.9, 48.0, 25.5, 23.9, 12.9. HRMS (ESI) Calcd for $\left[\mathrm{C}_{27} \mathrm{H}_{33} \mathrm{GeN}_{2} \mathrm{O}_{4}\right]^{-}[\mathrm{M}-\mathrm{H}]^{-:}$523.1652; Found: 523.1640 .

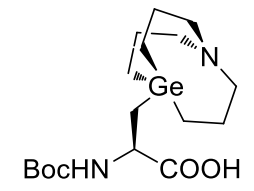

(R)-3-(1-aza-5-germabicyclo[3.3.3] undecan-5-yl)-2-((tert-butoxycarbonyl)amino)propanoic acid (a25). To a solution of compound a12 $(0.86 \mathrm{mmol})$ in THF $(10 \mathrm{~mL}) / \mathrm{H}_{2} \mathrm{O}(3 \mathrm{~mL})$ at room temperature was added $\mathrm{LiOH}(4.3 \mathrm{mmol})$ in an atmosphere of $\mathrm{Ar}$, and the mixture was stirred at $\mathrm{rt}$ for 12 hours and adjusted to $\mathrm{pH} 2$ with diluted hydrochloric acid $(1 \mathrm{M})$ and extracted with EtOAc $(20 \mathrm{~mL} \times 3)$. The combined organic layers were dried over $\mathrm{Na}_{2} \mathrm{SO}_{4}$ and concentrated in vacuo to give the compound without further purification as thick oil (the reaction process could be monitored by TLC using petroleum ether/EtOAc $=1 / 1$ as eluent, $R_{\mathrm{f}}=0.3,95 \%, 327 \mathrm{mg}$ ). ${ }^{1} \mathbf{H}$ NMR (400 MHz, CDCl $)_{3} \delta 4.79(\mathrm{~d}, J=8.0 \mathrm{~Hz}, 1 \mathrm{H}), 4.23-4.24(\mathrm{~m}, 1 \mathrm{H}), 2.50-2.30(\mathrm{~m}, 6 \mathrm{H})$, 1.44-1.59 (m, 15H), 0.96-0.64 (m, 8H). ${ }^{13} \mathbf{C}$ NMR (101 MHz, $\left.\mathbf{C D C l}_{3}\right) \delta 130.2,128.4,54.8,53.8$, 28.5, 23.3, 22.5, 14.4, 12.6. HRMS (ESI) Calcd for $\left[\mathrm{C}_{17} \mathrm{H}_{33} \mathrm{GeN}_{2} \mathrm{O}_{4}\right]^{+}[\mathrm{M}+\mathrm{H}]^{+}: 403.1652$; Found: 403.1649 .

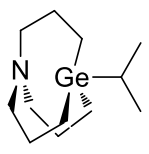

5-isopropyl-1-aza-5-germabicyclo[3.3.3] undecane. The general Route A for the preparation of 5-isopropyl-1-aza-5-germabicyclo[3.3.3] undecane was employed on $1 \mathrm{mmol}$ scale. The reaction mixture was extracted with petroleum ether, and the crude product could be isolated by silica gel column chromatography (300-400 mesh) as colorless oil (using petroleum ether as eluent, $\left.\mathbf{R}_{\mathrm{f}}=0.9,243 \mathrm{mg}, 95 \%\right) .{ }^{1} \mathbf{H}$ NMR (400 MHz, $\left.\mathbf{C}_{\mathbf{6}} \mathbf{D}_{\mathbf{6}}\right) \delta 2.24-2.12(\mathrm{~m}, 6 \mathrm{H}), 1.47-$ $1.37(\mathrm{~m}, 6 \mathrm{H}), 1.14(\mathrm{~d}, J=7.3 \mathrm{~Hz}, 6 \mathrm{H}), 0.81-0.70(\mathrm{~m}, 1 \mathrm{H}), 0.69-0.59(\mathrm{~m}, 6 \mathrm{H}) .{ }^{\mathbf{1 3}} \mathbf{C}$ NMR $(\mathbf{1 0 1}$ MHz, $\left.\mathbf{C}_{6} \mathbf{D}_{6}\right) \delta 53.9,24.0,20.1,19.4$, 9.3. GC-MS (EI) Calcd for $\left[\mathrm{C}_{12} \mathrm{H}_{25}{ }^{74} \mathrm{GeN}\right] 257$; Found: 257, 214.

\subsubsection{Preparation procedure and chiral HPLC data of compound a18}

All reactions were performed in oven-dried glassware under an atmosphere of $\mathrm{Ar}$ unless otherwise noted.

1) Preparation of 2-fluorobiphenyl-4-carboxaldehyde: To a solution of 4-bromo-2-fluoro-1,1'-biphenyl (3 g, $12 \mathrm{mmol}$ ) in anhydrous THF (30 mL), n-BuLi (13.2 mmol, $8.25 \mathrm{~mL}$ ) was slowly added at $-78^{\circ} \mathrm{C}$. The solution was kept at this temperature for 1 hour and then anhydrous DMF (13.2 mmol, $1 \mathrm{~mL})$ was added slowly. The reaction was stirred at room temperature for one night and extracted with $\mathrm{CH}_{2} \mathrm{Cl}_{2}$. The organic phase was dried over $\mathrm{Na}_{2} \mathrm{SO}_{4}$, concentrated in vacuo and purified on silica gel column chromatography $\left(3.3 \%\right.$ EtOAc in petroleum ether, $\mathrm{R}_{\mathrm{f}}=$ $0.4)$ to afford the desired 2-fluorobiphenyl-4-carboxaldehyde as white solid with the yield of $70 \%$. 


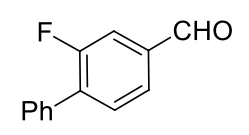

2-fluoro-[1,1'-biphenyl]-4-carbaldehyde. ${ }^{1} \mathrm{H}$ NMR (400 $\left.\mathbf{M H z}, \mathbf{C D C l}_{3}\right) \delta 10.02$ $(\mathrm{d}, J=1.7 \mathrm{~Hz}, 1 \mathrm{H}), 7.75(\mathrm{dd}, J=7.8,1.5 \mathrm{~Hz}, 1 \mathrm{H}), 7.70-7.55(\mathrm{~m}, 4 \mathrm{H}), 7.53-7.40(\mathrm{~m}, 3 \mathrm{H}) .{ }^{13} \mathbf{C}$ NMR (101 MHz, CDCl $)_{3} \delta 190.8(\mathrm{~d}, J=1.9 \mathrm{~Hz}), 160.1(\mathrm{~d}, J=251.2 \mathrm{~Hz}), 137.2(\mathrm{~d}, J=6.6 \mathrm{~Hz})$, $135.4(\mathrm{~d}, J=13.8 \mathrm{~Hz}), 134.6,131.6(\mathrm{~d}, J=3.4 \mathrm{~Hz}), 129.2(\mathrm{~d}, J=3.1 \mathrm{~Hz}), 128.9,128.8,126.2(\mathrm{~d}, J$ $=3.4 \mathrm{~Hz}), 116.5(\mathrm{~d}, J=23.7 \mathrm{~Hz})$. HRMS (ESI) Calcd for $\left[\mathrm{C}_{13} \mathrm{H}_{10} \mathrm{FO}\right]^{+}[\mathrm{M}+\mathrm{H}]^{+}: 201.0716$; Found: 201.0714 .

2) Preparation of 1-(2-fluoro-1,1'-biphenyl-4-yl)ethanol: To a solution of 2-fluorobiphenyl-4-carboxaldehyde (1.108 g, $5.54 \mathrm{mmol})$ in anhydrous THF (12 mL), methyl magnesium bromide ( $3 \mathrm{M}$ solution in tetrahydrofuran, $8.21 \mathrm{~mL}$ ) was added dropwise at $-78^{\circ} \mathrm{C}$. The temperature of the reaction was allowed to rise back to room temperature, at which the mixture was stirred for 4 hours. Then, $2 \mathrm{M}$ hydrochloric acid was added, and the mixture was extracted with ethyl acetate. The organic phase was dried over $\mathrm{Na}_{2} \mathrm{SO}_{4}$, concentrated in vacuo and purified on silica gel column chromatography (25\% EtOAc in petroleum ether, $\mathrm{R}_{\mathrm{f}}=0.33$ ) to afford the desired 1-(2-fluoro-1,1'-biphenyl-4-yl)ethanol as colorless oil with the yield of $46 \%$.<smiles>CC(O)c1ccc(-c2ccccc2)c(F)c1</smiles>

1-(2-fluoro-[1,1'-biphenyl]-4-yl)ethanol. ${ }^{1} \mathrm{H}$ NMR (400 $\left.\mathbf{~ M H z , ~} \mathbf{C D C l}_{3}\right) \delta 7.56$ $-7.52(\mathrm{~m}, 2 \mathrm{H}), 7.48-7.32(\mathrm{~m}, 4 \mathrm{H}), 7.23-7.15(\mathrm{~m}, 2 \mathrm{H}), 4.93(\mathrm{q}, J=6.5 \mathrm{~Hz}, 1 \mathrm{H}), 1.90(\mathrm{~s}, 1 \mathrm{H})$, $1.52(\mathrm{~d}, J=6.5 \mathrm{~Hz}, 3 \mathrm{H}) .{ }^{13} \mathbf{C}$ NMR $\left(\mathbf{1 0 1} \mathbf{M H z}, \mathbf{C D C l}_{3}\right) \delta 159.9(\mathrm{~d}, J=248.3 \mathrm{~Hz}), 147.6(\mathrm{~d}, J=$ $7.0 \mathrm{~Hz}$ ), 135.7, 130.9 (d, $J=3.9 \mathrm{~Hz}), 129.1$ (d, $J=2.9 \mathrm{~Hz}), 128.6,128.1$ (d, $J=13.7 \mathrm{~Hz}), 127.8$, $121.4(\mathrm{~d}, J=3.3 \mathrm{~Hz}), 113.2(\mathrm{~d}, J=23.6 \mathrm{~Hz}), 69.8(\mathrm{~d}, J=1.4 \mathrm{~Hz}), 25.3$. HRMS (ESI) Calcd for $\left[\mathrm{C}_{14} \mathrm{H}_{14} \mathrm{FO}\right]^{+}[\mathrm{M}+\mathrm{H}]^{+}:$217.1029; Found: 217.1056 .

3) Preparation of 1-chloro-1-(3-fluoro-4-phenylphenyl)ethane: To a solution of 1-(2-fluoro-1,1'-biphenyl-4-yl)ethanol (535 mg, $2.48 \mathrm{mmol}$ ) in $\mathrm{CHCI}_{3}, \mathrm{SOCl}_{2}$ (3.6 mL, $49.6 \mathrm{mmol}$ ) was slowly added at $0^{\circ} \mathrm{C}$ in air. The mixture was stirred for 10 hours at room temperature. The reaction was concentrated under vacuum and then extracted with petroleum ether. The organic phase was dried over $\mathrm{Na}_{2} \mathrm{SO}_{4}$, concentrated in vacuo and purified on silica gel column chromatography (20\% EtOAc in petroleum ether, $\left.\mathrm{R}_{\mathrm{f}}=0.9\right)$ to afford the desired 1-chloro-1-(3-fluoro-4-phenylphenyl)ethane as colorless oil with the yield of $67 \%$.<smiles>CC(Cl)c1ccc(-c2ccccc2)c(F)c1</smiles>

4-(1-chloroethyl)-2-fluoro-1,1'-biphenyl. ${ }^{1} \mathrm{H}$ NMR (400 MHz, $\left.\mathbf{C D C l}_{3}\right) \delta 7.56$ $7.50(\mathrm{~m}, 2 \mathrm{H}), 7.46-7.32(\mathrm{~m}, 4 \mathrm{H}), 7.26-7.20(\mathrm{~m}, 2 \mathrm{H}), 5.07$ (q, $J=6.8 \mathrm{~Hz}, 1 \mathrm{H}), 1.85(\mathrm{~d}, J=6.8$ $\mathrm{Hz}, 3 \mathrm{H}) .{ }^{13} \mathbf{C}$ NMR (101 MHz, CDCl $) \delta 190.8(\mathrm{~d}, J=1.9 \mathrm{~Hz}), 160.1(\mathrm{~d}, J=251.2 \mathrm{~Hz}), 137.2(\mathrm{~d}$, $J=6.6 \mathrm{~Hz}), 135.4(\mathrm{~d}, J=13.8 \mathrm{~Hz}), 134.6,131.6(\mathrm{~d}, J=3.4 \mathrm{~Hz}), 129.2(\mathrm{~d}, J=3.1 \mathrm{~Hz}), 128.9$, 128.8, $126.2(\mathrm{~d}, J=3.4 \mathrm{~Hz}), 116.5(\mathrm{~d}, J=23.7 \mathrm{~Hz})$. GC-MS (EI) Calcd for $\left[\mathrm{C}_{14} \mathrm{H}_{12} \mathrm{ClF}\right] 234$; Found: 234, 199.

4) Preparation of 5-(1-(2-fluoro-[1,1'-biphenyl]-4-yl)ethyl)-1-aza-5-germabicyclo[3.3.3] undecane (a15): To a $25 \mathrm{~mL}$ schlenk tube equipped with a tefloncoated magnetic stir bar, the 
5-bromo-1-aza-5-germabicyclo[3.3.3] undecane (1 mmol), $\mathrm{Mg}$ powder (3 mmol), anhydrous THF (5 mL) and 1-chloro-1-(3-fluoro-4-phenylphenyl)ethane (2 mmol) were added and stirred at room temperature for 8 hours. Then the mixture was concentrated and extracted with petroleum ether $/ \mathrm{H}_{2} \mathrm{O}$. The organic phase was separated and dried over $\mathrm{MgSO}_{4}$ and concentrated in vacuo to afford the 5-(1-(2-fluoro-[1,1'-biphenyl]-4-yl)ethyl)-1-aza-5-germabicyclo[3.3.3]undecane which could be purified by silica gel column chromatography using petroleum ether as eluent $\left(\mathrm{R}_{\mathrm{f}}=0.7\right)$ with the yield of $75 \%(309 \mathrm{mg})$ as white solid.<smiles>CC(O)c1ccc(-c2ccccc2)cc1</smiles>

5-(1-(2-fluoro-[1,1'-biphenyl]-4-yl)ethyl)-1-aza-5-germabicyclo[3.3.3] undecane. ${ }^{1} \mathrm{H} \quad \mathrm{NMR}$ $\left(400 \mathrm{MHz}, \mathbf{C}_{6} \mathbf{D}_{6}\right) \delta 7.60(\mathrm{~d}, J=7.5 \mathrm{~Hz}, 2 \mathrm{H}), 7.32-7.25(\mathrm{~m}, 1 \mathrm{H}), 7.24-7.17(\mathrm{~m}, 2 \mathrm{H}), 7.13-$ $7.05(\mathrm{~m}, 1 \mathrm{H}), 6.98(\mathrm{~d}, J=12.9 \mathrm{~Hz}, 1 \mathrm{H}), 6.87(\mathrm{~d}, J=7.9 \mathrm{~Hz}, 1 \mathrm{H}), 2.15-1.93(\mathrm{~m}, 7 \mathrm{H}), 1.44-1.19$ $(\mathrm{m}, 9 \mathrm{H}), 0.74-0.53(\mathrm{~m}, 6 \mathrm{H}) .{ }^{19} \mathbf{F}$ NMR (376 MHz, $\left.\mathbf{C}_{6} \mathbf{D}_{6}\right) \delta-119.14(\mathrm{~s}) .{ }^{13} \mathbf{C} \mathbf{N M R}(\mathbf{1 0 1} \mathbf{~ M H z}$, $\left.\mathbf{C}_{6} \mathbf{D}_{6}\right) \delta 160.4(\mathrm{~d}, J=246.0 \mathrm{~Hz}), 152.1(\mathrm{~d}, J=7.5 \mathrm{~Hz}), 137.0,130.2(\mathrm{~d}, J=4.3 \mathrm{~Hz}), 129.3(\mathrm{~d}, J=$ $3.0 \mathrm{~Hz}), 128.7,127.2,124.1$ (d, $J=13.6 \mathrm{~Hz}), 123.1$ (d, $J=2.8 \mathrm{~Hz}), 113.9$ (d, $J=22.4 \mathrm{~Hz}), 53.6$, $35.6,23.7,16.2,10.0$.

Optically

active

5-(1-(2-fluoro-[1,1'-biphenyl]-4-yl)ethyl)-1-aza-5-germabicyclo[3.3.3]undecane (a18) was prepared via preparatory chiral HPLC.

\begin{tabular}{ll}
\hline Column & CHIRALCEL OJ-H(OJH0CE-VD046) \\
\hline Column size & $0.46 \mathrm{~cm} \mathrm{I.D.} \times 25 \mathrm{~cm} \mathrm{~L}$ \\
Injection & $2.0 \mathrm{uL}$ \\
Mobile phase & EtOH/ACN=85/15 (V/V) \\
Flow rate & $2.0 \mathrm{~mL} / \mathrm{min}$ \\
Wave length & UV $254 \mathrm{~nm}$ \\
Temperature & $35^{\circ} \mathrm{C}$ \\
\hline
\end{tabular}




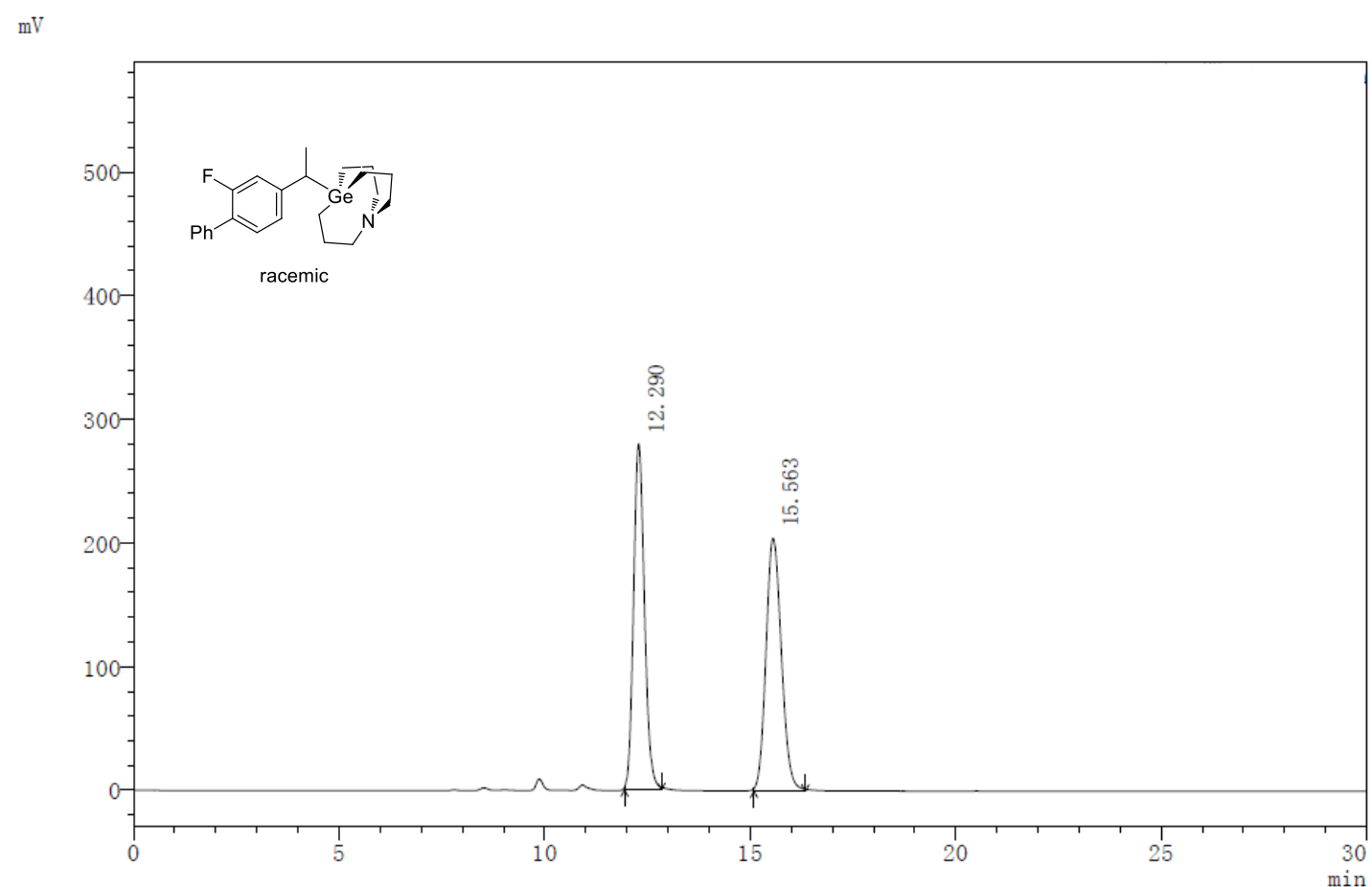

\begin{tabular}{|c|c|c|c|c|c|c|}
\hline Peak\# & Ret. Time & Area & Area\% & T.Plate\# & Tailing F. & Height \\
\hline 1 & 12.290 & 5204448 & 49.436 & 9951 & 1.148 & 279806 \\
\hline 2 & 15.563 & 5323126 & 50.564 & 8184 & 1.142 & 204655 \\
\hline
\end{tabular}

$\mathrm{mV}$

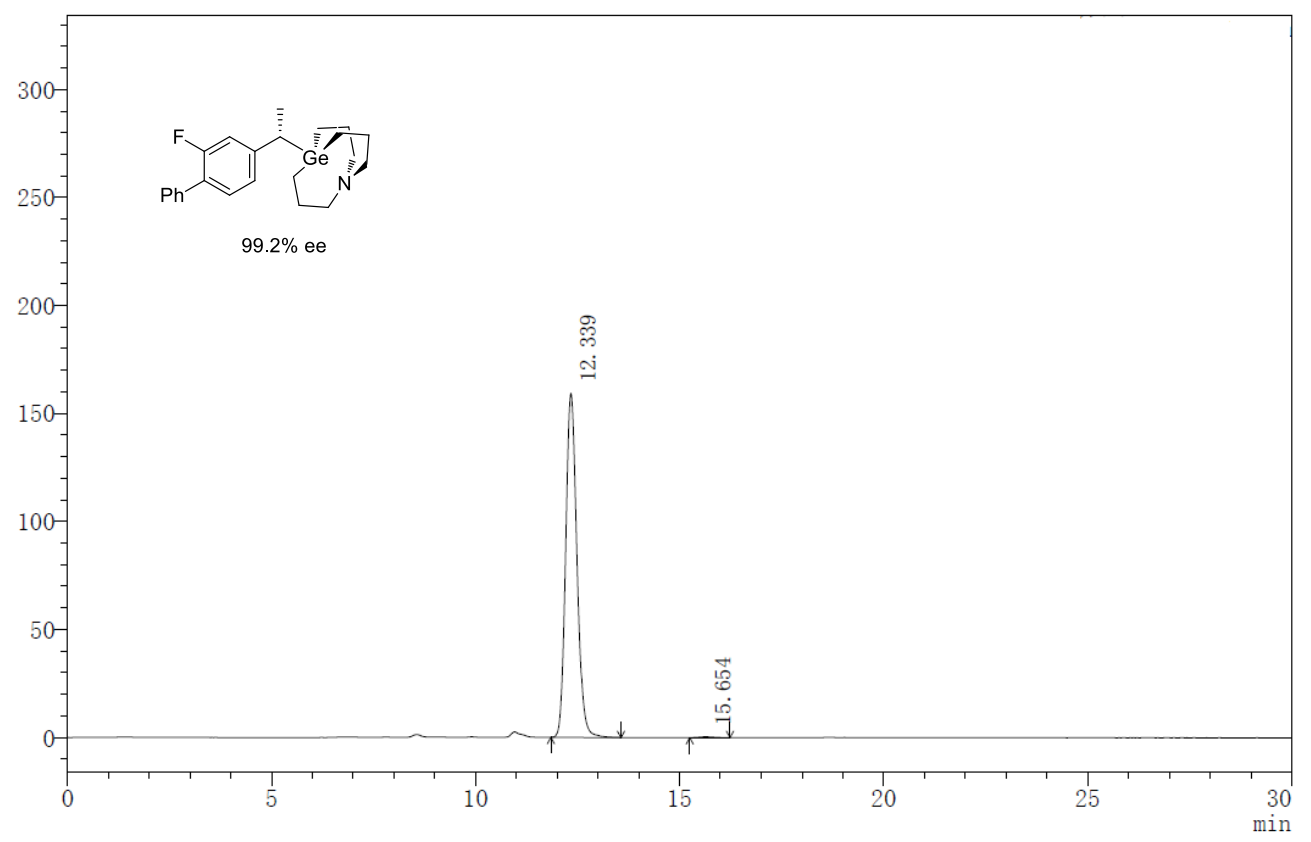

\begin{tabular}{|c|c|c|c|c|c|c|}
\hline Peak\# & Ret. Time & Area & Area\% & T.Plate\# & Tailing F. & Height \\
\hline 1 & 12.339 & 3075268 & 99.610 & 9444 & 1.146 & 159073 \\
\hline 2 & 15.654 & 12043 & 0.390 & 8560 & -- & 430 \\
\hline
\end{tabular}




\subsection{Preparation of ligands-Ls, L9, L10}

All reactions were performed in oven-dried glassware under an atmosphere of $\mathrm{Ar}$ unless otherwise noted.

Synthesis

of

bis(3,5-bis(trifluoromethyl)phenyl)(2-mesityl-1H-inden-3-yl)phosphine (L8):

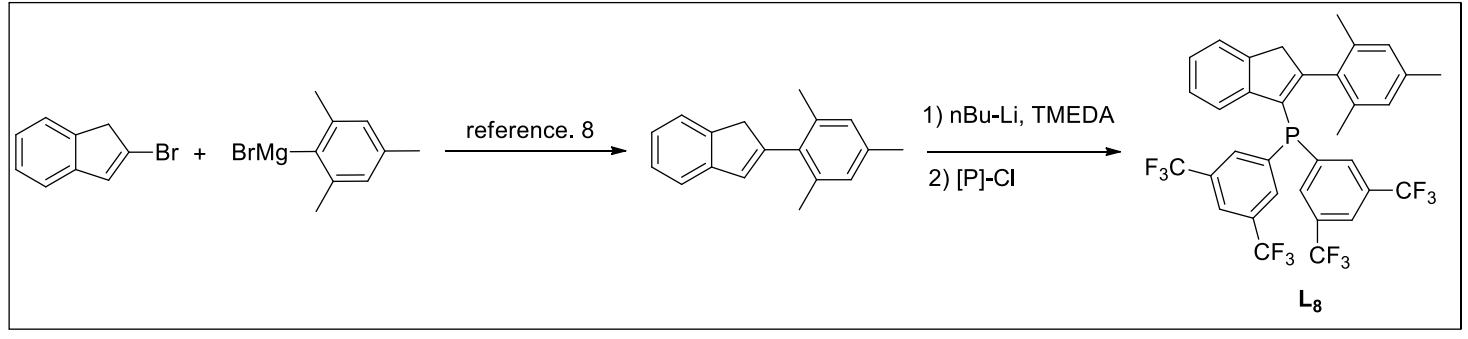

In a $50 \mathrm{~mL}$ schlenk tube 2-mesityl- $1 H$-indene ${ }^{8}(200 \mathrm{mg}, 0.85 \mathrm{mmol})$ was dissolved in anhydrous THF $(2 \mathrm{~mL})$ and hexane $(12 \mathrm{~mL})$, then the mixture was cooled to $-78^{\circ} \mathrm{C}$. TMEDA and $\mathrm{nBu}-\mathrm{Li}(0.812 \mathrm{~mL}, 1.6 \mathrm{M}$ in hexane, $1.3 \mathrm{mmol})$ were added dropwise before the solution was stirred for $30 \mathrm{~min}$ at this temperature, after that the mixture was warmed to room temperature and stirred for 8 hours. Then the bis(3,5-bis(trifluoromethyl)phenyl)chlorophosphine ( $0.3 \mathrm{~mL}, 1.2 \mathrm{mmol}$ ) was added dropwise at $0{ }^{\circ} \mathrm{C}$ and stirred for additional 8 hours. The reaction was quenched with water and extracted with petroleum ether $(50 \mathrm{~mL})$. The organic phase was separated and dried over $\mathrm{MgSO}_{4}$ and concentrated in vacuo to afford the product $\mathbf{L s}$ which could be purified by silica gel column chromatography (300-400 mesh) using petroleum ether as eluent $\left(\mathrm{R}_{\mathrm{f}}=0.7\right)$ with a yield of $71 \%(416 \mathrm{mg})$ as light yellow solid.<smiles>Cc1cc(C)c2c(c1)Cc1ccccc1P2c1cc(C(F)(F)F)cc(C(F)(F)F)c1</smiles>

Bis(3,5-bis(trifluoromethyl)phenyl)(2-mesityl-1H-inden-3-yl)phosphine.

${ }^{1}$ H NMR (400 MHz, C6 $\left.\mathbf{6}_{6}\right) \delta 7.81(\mathrm{~d}, J=6.3 \mathrm{~Hz}, 4 \mathrm{H}), 7.53(\mathrm{~s}, 2 \mathrm{H}), 7.17(\mathrm{~s}, 1 \mathrm{H}), 7.03-6.95(\mathrm{~m}$, 3H), 6.53 (s, 2H), 3.27 (s, 2H), 2.00 (s, 3H), 1.87 (s, 6H). ${ }^{19} \mathbf{F}$ NMR (376 MHz, $\left.\mathbf{C}_{6} \mathbf{D}_{6}\right) \delta-63.09(\mathrm{~s})$. ${ }^{31} \mathbf{P}$ NMR (162 MHz, $\left.\mathbf{C}_{6} \mathbf{D}_{6}\right) \delta-21.69$ (s). ${ }^{13} \mathbf{C}$ NMR (101 MHz, $\left.\mathbf{C}_{6} \mathbf{D}_{6}\right) \delta 161.9(\mathrm{~d}, J=20.7 \mathrm{~Hz})$, $144.3(\mathrm{~d}, J=10.3 \mathrm{~Hz}), 142.9$ (d, $J=4.3 \mathrm{~Hz}), 138.3(\mathrm{~d}, J=17.8 \mathrm{~Hz}), 137.6,135.0,132.8-133.2$ (m), 132.0 (qd, $J=33.3 \mathrm{~Hz}, J=6.0 \mathrm{~Hz}), 130.6(\mathrm{~d}, J=15.1 \mathrm{~Hz}), 128.6,126.9,125.9,124.9,123.5$ $(\mathrm{q}, J=273.7 \mathrm{~Hz}), 122.8-123.1(\mathrm{~m}), 121.6(\mathrm{~d}, J=4.2 \mathrm{~Hz}), 45.0(\mathrm{~d}, J=5.4 \mathrm{~Hz}), 20.8,20.2$. HRMS (ESI) Calcd for $\left[\mathrm{C}_{34} \mathrm{H}_{24} \mathrm{~F}_{12} \mathrm{P}\right]^{+}[\mathrm{M}+\mathrm{H}]^{+}$: 691.1424; Found: 691.1425.

Synthesis

of

bis(3,5-bis(trifluoromethyl)phenyl)(2-(2,6-dimethoxyphenyl)-1H-inden-3-yl)-pho sphine (L9): 


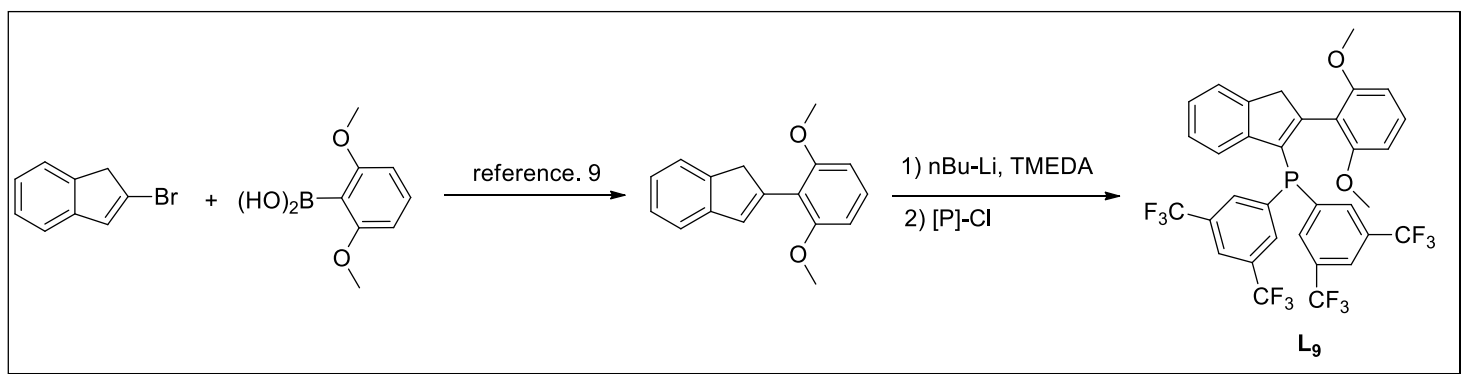

In a $50 \mathrm{~mL}$ schlenk tube 2-(2, 6-dimethoxyphenyl)- $1 H$-indene ${ }^{9}(200 \mathrm{mg}, 0.80 \mathrm{mmol})$ was dissolved in anhydrous THF $(2 \mathrm{~mL})$ and hexane $(12 \mathrm{~mL})$, and then the mixture was cooled to $-78{ }^{\circ} \mathrm{C}$. TMEDA and $\mathrm{nBu}-\mathrm{Li}(0.812 \mathrm{~mL}, 1.6 \mathrm{M}$ in hexane, $1.3 \mathrm{mmol})$ were added dropwise before the solution was stirred for $30 \mathrm{~min}$ at this temperature, after that the mixture was warmed to room temperature and stirred for 8 hours. Then the bis(3,5-bis(trifluoromethyl)phenyl)chlorophosphine $(0.3 \mathrm{~mL}, 1.2 \mathrm{mmol})$ was added dropwise at $0{ }^{\circ} \mathrm{C}$ and stirred for additional 8 hours. The reaction was quenched with water and extracted with EtOAc $(50 \mathrm{~mL})$. The organic phase was separated and dried over $\mathrm{MgSO}_{4}$ and concentrated in vacuo to afford the product $\mathbf{L} \mathbf{9}$ which could be purified by silica gel column chromatography (300-400 mesh) using petroleum ether/EtOAc $(50 / 1)$ as eluent $\left(\mathrm{R}_{\mathrm{f}}=0.6\right)$ with a yield of $30 \%(169 \mathrm{mg})$ as light yellow solid.

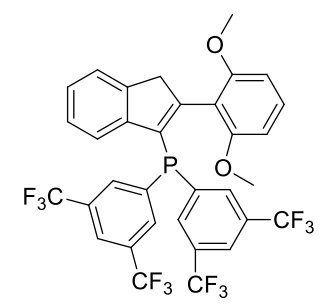

Bis(3,5-bis(trifluoromethyl)phenyl)(2-(2,6-dimethoxyphenyl)-1H-inden-3-yl)-phosphine. $\quad{ }^{1} \mathrm{H}$ NMR (400 MHz, C6 $\left.\mathbf{D}_{6}\right) \delta 7.93(\mathrm{~d}, J=6.1 \mathrm{~Hz}, 4 \mathrm{H}), 7.54(\mathrm{~s}, 2 \mathrm{H}), 7.14(\mathrm{~s}, 1 \mathrm{H}), 6.92-7.00(\mathrm{~m}, 3 \mathrm{H})$, $6.85(\mathrm{t}, J=8.4 \mathrm{~Hz}, 1 \mathrm{H}), 6.07$ (d, $J=8.4 \mathrm{~Hz}, 2 \mathrm{H}), 3.70(\mathrm{~s}, 2 \mathrm{H}), 3.23$ (s, 6H). ${ }^{19} \mathbf{F}$ NMR (376 MHz, $\left.\mathbf{C}_{6} \mathbf{D}_{6}\right) \delta$-62.76 (s). ${ }^{31} \mathbf{P}$ NMR (162 MHz, $\left.\mathbf{C}_{6} \mathbf{D}_{6}\right) \delta-22.86(\mathrm{~s}) .{ }^{13} \mathbf{C}$ NMR (101 MHz, $\left.\mathbf{C}_{6} \mathbf{D}_{\mathbf{6}}\right) \delta$ 157.4, $155.4(\mathrm{~d}, J=19.7 \mathrm{~Hz}), 144.8(\mathrm{~d}, J=11.3 \mathrm{~Hz}), 143.8(\mathrm{~d}, J=4.6 \mathrm{~Hz}), 138.8(\mathrm{~d}, J=17.9 \mathrm{~Hz}), 133.0$ $(\mathrm{d}, J=17.4 \mathrm{~Hz}), 131.7$ (qd, $J=33.3 \mathrm{~Hz}, J=6.0 \mathrm{~Hz}), 131.5(\mathrm{~d}, J=6.6 \mathrm{~Hz}), 129.9,126.5,125.6$, 124.4, 123.7 (q, $J=273.7 \mathrm{~Hz}), 122.6-122.9(\mathrm{~m}), 121.2(\mathrm{~d}, J=4.7 \mathrm{~Hz}), 114.4(\mathrm{~d}, J=3.5 \mathrm{~Hz})$, 103.7, 54.9, $44.8(\mathrm{~d}, J=5.5 \mathrm{~Hz})$. HRMS (ESI) Calcd for $\left[\mathrm{C}_{33} \mathrm{H}_{22} \mathrm{~F}_{12} \mathrm{O}_{2} \mathrm{P}\right]^{+}[\mathrm{M}+\mathrm{H}]^{+}:$709.1166; Found: 709.1131.

\section{Synthesis of}

bis(3,5-bis(trifluoromethyl)phenyl)(2-((2,4,6-triisopropylphenyl)-1H-inden-3-yl)p hosphine (L10):

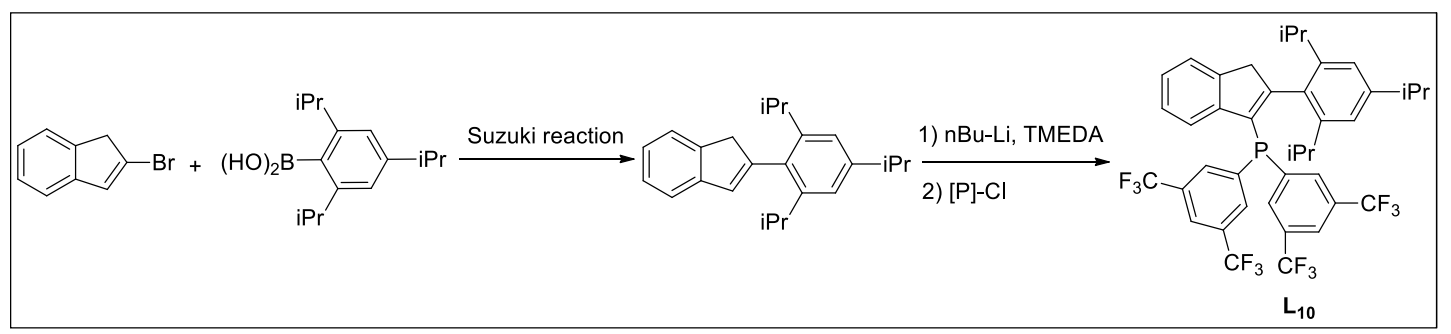


To a schlenk flask equipped with a tefloncoated magnetic stir bar, (2,4,6-triisopropylphenyl)boronic acid $(12 \mathrm{mmol})$ and 2-bromo- $1 H$-indene (10 mmol), $\mathrm{KOH}(30 \mathrm{mmol}), \mathrm{Pd}(\mathrm{OAc})_{2}(0.6 \mathrm{mmol})$, Sphos $(0.4 \mathrm{mmol})$, dioxane $(120 \mathrm{~mL})$ were added and stirred at $100{ }^{\circ} \mathrm{C}$ for 24 hours. The reaction was quenched with water and extracted with petroleum ether $(100 \mathrm{~mL})$. The organic phase was separated and dried over $\mathrm{MgSO}_{4}$ and concentrated in vacuo to afford the 2-(2,4,6-triisopropylphenyl)-1H-indene which could be purified by silica gel column chromatography using petroleum ether as eluent $\left(\mathrm{R}_{\mathrm{f}}=0.7\right)$ with a yield of $85 \%(2.7 \mathrm{~g})$ as white solid.

In a $50 \mathrm{~mL}$ schlenk tube, 2-(2,4,6-triisopropylphenyl)-1H-indene (200 mg, 0.80 mmol) obtained from above was dissolved in anhydrous THF (2 mL) and hexane (12 $\mathrm{mL}$ ), and then the mixture was cooled to $-78{ }^{\circ} \mathrm{C}$. TMEDA and $\mathrm{nBu}-\mathrm{Li}(0.812 \mathrm{~mL}, 1.6$ $\mathrm{M}$ in hexane, $1.3 \mathrm{mmol}$ ) were added dropwise before the solution was stirred for 30 min at this temperature, after that the mixture was warmed to room temperature and stirred for 8 hours. Then the bis(3,5-bis(trifluoromethyl)phenyl)chlorophosphine ( 0.3 $\mathrm{mL}, 1.2 \mathrm{mmol}$ ) was added dropwise at $0{ }^{\circ} \mathrm{C}$ and stirred for additional 8 hours. The reaction was quenched with water and extracted with petroleum ether $(50 \mathrm{~mL})$. The organic phase was separated and dried over $\mathrm{MgSO}_{4}$ and concentrated in vacuo to afford the product $\mathbf{L} 10$ which could be purified by silica gel column chromatography (300-400 mesh) using petroleum ether as eluent $\left(\mathrm{R}_{\mathrm{f}}=0.7\right)$ with a yield of $67 \%(414$ $\mathrm{mg}$ ) as light yellow solid.

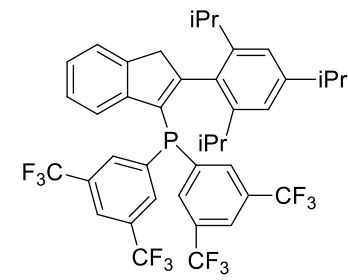

Bis(3,5-bis(trifluoromethyl)phenyl)(2-((2,4,6-triisopropylphenyl)-1 $H$-inden-3-yl)phosphine. ${ }^{1} \mathbf{H}$ NMR $\left(400 \mathrm{MHz}, \mathbf{C}_{\mathbf{6}} \mathbf{D}_{\mathbf{6}}\right) \delta 7.87(\mathrm{~d}, J=5.6 \mathrm{~Hz}, 4 \mathrm{H}), 7.61(\mathrm{~s}, 2 \mathrm{H}), 7.13(\mathrm{~s}, 2 \mathrm{H}), 7.11(\mathrm{~s}, 1 \mathrm{H})$, $6.95-6.85(\mathrm{~m}, 1 \mathrm{H}), 6.85-6.80(\mathrm{~m}, 1 \mathrm{H}), 6.67(\mathrm{~d}, J=7.6 \mathrm{~Hz}, 1 \mathrm{H}), 3.59(\mathrm{~s}, 2 \mathrm{H}), 2.87-2.73(\mathrm{~m}$, $3 \mathrm{H}), 1.18(\mathrm{~d}, J=6.9 \mathrm{~Hz}, 6 \mathrm{H}), 1.14(\mathrm{~d}, J=6.8 \mathrm{~Hz}, 6 \mathrm{H}), 1.09(\mathrm{~d}, J=6.8 \mathrm{~Hz}, 6 \mathrm{H}),{ }^{19}$ F NMR $(376$ MHz, $\left.\mathbf{C}_{6} \mathbf{D}_{\mathbf{6}}\right) \delta-63.05$ (s). ${ }^{31} \mathbf{P}$ NMR (162 MHz, $\left.\mathbf{C}_{6} \mathbf{D}_{\mathbf{6}}\right) \delta-29.09$ (s). $\left.{ }^{13} \mathbf{C ~ N M R ~ ( 1 0 1 ~ M H z , ~} \mathbf{C}_{6} \mathbf{D}_{\mathbf{6}}\right) \delta$ $168.3(\mathrm{~d}, J=42.8 \mathrm{~Hz}), 149.9,146.7,143.3(\mathrm{~d}, 2.0 \mathrm{~Hz}), 142.9$ (d, $5.0 \mathrm{~Hz}), 139.5$ (d, $J=20.6 \mathrm{~Hz})$, $132.6(\mathrm{~d}, J=12.6 \mathrm{~Hz}), 132.3(\mathrm{qd}, J=33.3 \mathrm{~Hz}, J=5.0 \mathrm{~Hz}), 132.0-131.8(\mathrm{~m}), 131.0(\mathrm{~d}, J=7.1 \mathrm{~Hz})$, 127.0, 126.1, 125.1, 123.6 (q, $J=273.7 \mathrm{~Hz}), 122.7-122.4(\mathrm{~m}), 122.2,121.5,47.4(\mathrm{~d}, J=8.3 \mathrm{~Hz})$, 34.7, 31.7, 25.3, $24.2(\mathrm{~d}, J=4.2 \mathrm{~Hz})$. HRMS (ESI) Calcd for $\left[\mathrm{C}_{40} \mathrm{H}_{36} \mathrm{~F}_{12} \mathrm{P}\right]^{+}[\mathrm{M}+\mathrm{H}]^{+}$: 775.2363; Found: 775.2351 .

\subsection{Preparation and characterization data of cross-coupling products}

\subsubsection{Preparation of aryl halides and general procedure for cross-coupling reactions}

Preparation of aryl halides: Most of aryl (alkenyl) halides were purchased from commercial source and could be used without further purification, or some aryl 
halides could be prepared according to the relevant references. Some new aryl halides were prepared as follow:<smiles>O=S(=O)(NCCCO)c1ccc(Br)cc1</smiles>

4-bromo- $\mathrm{N}$-(3-hydroxypropyl)benzenesulfonamide, To a $50 \mathrm{~mL}$ flask charged with 3-aminopropanol ( $0.382 \mathrm{~mL}, 5.0 \mathrm{mmol}, 1.0$ equiv), trimethyl chlorosilane $(0.432 \mathrm{~mL}$, 5.0 mmol, 1.0 equiv) and triethylamine $(1.7 \mathrm{~mL}, 7.5 \mathrm{mmol}, 1.50$ equiv) was added dichloromethane $(20 \mathrm{~mL})$ at $0{ }^{\circ} \mathrm{C}$. The reaction mixture was stirred for 10 hours at room temperature. Then the mixture was extracted with dichloromethane/ $\mathrm{H}_{2} \mathrm{O}$. The organic phase was separated and dried over $\mathrm{MgSO}_{4}$ and concentrated in vacuo to afford the crude product which could be used without purification. To a $50 \mathrm{~mL}$ flask charged with the product from above $(0.172$ $\mathrm{mL}, 1.0 \mathrm{mmol}, 1.0$ equiv), 4-bromo-benzenesulfonyl chloride ( $256 \mathrm{mg}, 1.0 \mathrm{mmol}, 1.0$ equiv) and triethylamine $\left(0.208 \mathrm{~mL}, 1.5 \mathrm{mmol}, 1.50\right.$ equiv) was added EtOAc $(10 \mathrm{~mL})$ at $0{ }^{\circ} \mathrm{C}$. The reaction mixture was stirred for 1 hour at room temperature. Then the mixture was extracted with EtOAc $/ \mathrm{H}_{2} \mathrm{O}$. The organic phase was separated and dried over $\mathrm{MgSO}_{4}$ and concentrated in vacuo to afford the crude product which could be used without purification. To a $50 \mathrm{~mL}$ flask charged with the product from above and $2 \mathrm{M} \mathrm{HCl}$ aq. $(5 \mathrm{~mL})$ was added THF $(5 \mathrm{~mL})$ at room temperature. The reaction mixture was stirred for 1 hour at room temperature. Then the mixture was extracted with EtOAc $/ \mathrm{H}_{2} \mathrm{O}$. The organic phase was separated and dried over $\mathrm{MgSO}_{4}$ and concentrated in vacuo to afford the crude product which could be isolated by silica gel column chromatography (300-400 mesh) as white solid (using petroleum ether/EtOAc $=1 / 1$ as eluent, $\mathrm{R}_{\mathrm{f}}=0.4,80 \%, 234 \mathrm{mg}$ ). ${ }^{1} \mathbf{H}$ NMR (400 MHz, CDCl $) \delta 7.74(\mathrm{~d}, J=8.6 \mathrm{~Hz}, 2 \mathrm{H}), 7.66(\mathrm{~d}, J=8.6 \mathrm{~Hz}, 2 \mathrm{H}), 5.35$ (brs, 1H), 3.75 $(\mathrm{t}, J=5.6 \mathrm{~Hz}, 2 \mathrm{H}), 3.12(\mathrm{t}, J=6.1 \mathrm{~Hz}, 2 \mathrm{H}), 1.92(\mathrm{brs}, 1 \mathrm{H}), 1.79-1.62(\mathrm{~m}, 2 \mathrm{H}) .{ }^{13} \mathbf{C}$ NMR $(101$ MHz, $\left.\mathbf{C D C l}_{3}\right) \delta 139.1,132.6,128.8,127.8,61.0,41.5,31.4$. HRMS (ESI) Calcd for $\left[\mathrm{C}_{9} \mathrm{H}_{12} \mathrm{BrNO}_{3} \mathrm{SNa}\right]^{+}[\mathrm{M}+\mathrm{Na}]^{+}: 315.9619$; Found: 315.9616 .<smiles>O=C(CCCCC1SCC2NC(=O)NC21)Nc1ccc(Br)cc1</smiles>

$\mathrm{N}$-(4-bromophenyl)-5-((3aS,4S,6aR)-2-oxohexahydro-1H-thieno[3,4-d]imidazol-4-yl)pentana mide. To a $250 \mathrm{~mL}$ flask charged with biotin ( $2.44 \mathrm{~g}, 10.0 \mathrm{mmol}, 1.00$ equiv), 4-bromoaniline (1.89 g, $11.0 \mathrm{mmol}, 1.10$ equiv) and HATU ( $3.80 \mathrm{~g}, 10.0 \mathrm{mmol}, 1.00$ equiv) was added DMF (50 $\mathrm{mL})$, followed by DIEA (1.92 mL, $11.0 \mathrm{mmol}, 1.10$ equiv). The reaction mixture was vigorously stirred for 16 hours at room temperature. At the end of the reaction, large quantities of white solid particles were precipitated from the solution which were filtered and washed with EtOAc $(50 \mathrm{~mL})$. The white solid was collected and dried under vacuum (2.38 g, 60\%). ${ }^{1} \mathbf{H}$ NMR (400 MHz, DMSO) $\delta 10.02(\mathrm{~s}, 1 \mathrm{H}), 7.57(\mathrm{~d}, J=8.9 \mathrm{~Hz}, 2 \mathrm{H}), 7.46(\mathrm{~d}, J=8.8 \mathrm{~Hz}, 2 \mathrm{H}), 6.45(\mathrm{~s}, 1 \mathrm{H}), 6.37(\mathrm{~s}$, $1 \mathrm{H}), 4.31(\mathrm{dd}, J=7.6,5.2 \mathrm{~Hz}, 1 \mathrm{H}), 4.18-4.11(\mathrm{~m}, 1 \mathrm{H}), 3.17-3.06(\mathrm{~m}, 1 \mathrm{H}), 2.82(\mathrm{dd}, J=12.4$, $5.1 \mathrm{~Hz}, 1 \mathrm{H}), 2.58(\mathrm{~d}, J=12.4 \mathrm{~Hz}, 1 \mathrm{H}), 2.31(\mathrm{t}, J=7.4 \mathrm{~Hz}, 2 \mathrm{H}), 1.72-1.27(\mathrm{~m}, 6 \mathrm{H}) .{ }^{13} \mathbf{C}$ NMR (101 MHz, DMSO) $\delta 171.4,162.8,138.7,131.5,120.9,114.5,61.1,59.2,55.4,36.3,28.3,28.1$, 25.0. HRMS (ESI) Calcd for $\left[\mathrm{C}_{16} \mathrm{H}_{21} \mathrm{BrN}_{3} \mathrm{O}_{2} \mathrm{~S}\right]^{+}[\mathrm{M}+\mathrm{H}]^{+}: 398.0538$; Found: 398.0541 .

General procedure of screening ligands for cross-coupling reactions: $\mathrm{Pd}(\mathrm{dba})_{2}$ (1.2 mg, $0.002 \mathrm{mmol}, 2 \mathrm{~mol} \%$ ), monodentate ligands $\mathrm{L}_{1}-\mathrm{L}_{4} \& \mathrm{~L}_{7}-\mathrm{L}_{10}$ (0.006 mmol, 6 mol\%) or bidentate ligands $\mathrm{L}_{5}-\mathrm{L}_{6}(0.003 \mathrm{mmol}, 3 \mathrm{~mol} \%)$ and the $n$ hexyl-Ge $(35.8 \mathrm{mg}$, $0.12 \mathrm{mmol}, 1.2 \mathrm{eq})$ were weighed and transferred to a screw-cap tube with stir bar. 
The tube was evacuated and backfilled three times with argon, then $\mathrm{CH}_{3} \mathrm{CN}(0.5 \mathrm{~mL})$ and bromobenzene $(0.0105 \mathrm{~mL}, 0.1 \mathrm{mmol}, 1 \mathrm{eq})$ was added and the screw-cap tube was sealed with a Teflon stopper and heated to $120{ }^{\circ} \mathrm{C}$ for 16 hours. At the end of the reaction, the mixture was cooled to room temperature, cyclohexylbenzene $(0.0168 \mathrm{~mL}$, $0.1 \mathrm{mmol}, 1 \mathrm{eq})$ was added as internal standard and then the solution was diluted by EtOAc ( $3 \mathrm{~mL})$. The yield of product was determined by GC.

General procedure for cross-coupling reactions and recovery of $\mathrm{GeBr}$ : $\operatorname{Pd}(\mathrm{dba})_{2}(2 \mathrm{~mol} \%)$, ligand $\mathrm{L}_{10}(6 \mathrm{~mol} \%)$, aryl halides (1 eq) and the corresponding alkyl carbagermatranes (1.2 eq) were weighed and transferred to a screw-cap tube with stir bar. The tube was evacuated and backfilled three times with argon, then $\mathrm{CH}_{3} \mathrm{CN}$ was added and the screw-cap tube was sealed with a Teflon stopper and heated to $120{ }^{\circ} \mathrm{C}$ or $100{ }^{\circ} \mathrm{C}$ for 12 or 16 hours. At the end of the reaction, the reaction mixture was cooled to room temperature and then the tube was settled at $-20{ }^{\circ} \mathrm{C}$ for 2 hours. Most of $\boldsymbol{G e B r}$ was precipitated from the solution which could be recovered through filtration, and filtrate was concentrated to provide the crude product. The crude product was purified by preparative TLC.<smiles>BrCCCN1C2CCC1CC(Br)C2</smiles>

5-bromo-1-aza-5-germabicyclo[3.3.3] undecane (recovered from reaction mixture). Most of $\boldsymbol{G e B r}$ was precipitated from the solution which could be recovered through filtration. The solid obtained by filtration was redissolved in dichloromethane, then filtered to remove palladium black. Filtrate was concentrated to provide the recovered $\mathrm{GeBr}$ which could be further purified by recrystallization from THF. ${ }^{1} \mathbf{H}$ NMR $\left(\mathbf{4 0 0} \mathbf{~ M H z}, \mathbf{C D C l}_{\mathbf{3}}\right) \delta 2.63(\mathrm{t}, J=6.0 \mathrm{~Hz}$, 6H), $1.87-1.77(\mathrm{~m}, 6 \mathrm{H}), 1.54(\mathrm{t}, J=6.9 \mathrm{~Hz}, 6 \mathrm{H}) .{ }^{1} \mathbf{H} \mathbf{~ N M R}\left(\mathbf{4 0 0} \mathbf{~ M H z}, \mathbf{C D}_{2} \mathbf{C l}_{2}\right) \delta 2.60(\mathrm{t}, J=6.0$ $\mathrm{Hz}, 6 \mathrm{H}), 1.86-1.73(\mathrm{~m}, 6 \mathrm{H}), 1.47(\mathrm{t}, J=6.9 \mathrm{~Hz}, 6 \mathrm{H})$. (Relative to the solvent resonance as the internal standard: $\left.\mathrm{CD}_{2} \mathrm{Cl}_{2}, \delta 5.33 \mathrm{ppm}\right)$. We compared the NMR spectrum of synthesized $\boldsymbol{G e B r}$ and recovered $\boldsymbol{G e} \mathrm{Br}$ in $\mathrm{CD}_{2} \mathrm{Cl}_{2}$ and $\mathrm{CDCl}_{3}$ and they are in accordance with each other. Besides, the X-ray structure of recovered $\mathrm{GeBr}$ was acquired. Single crystals were grown by slow evaporation from $\mathrm{CHCl}_{3}$ at room temperature.

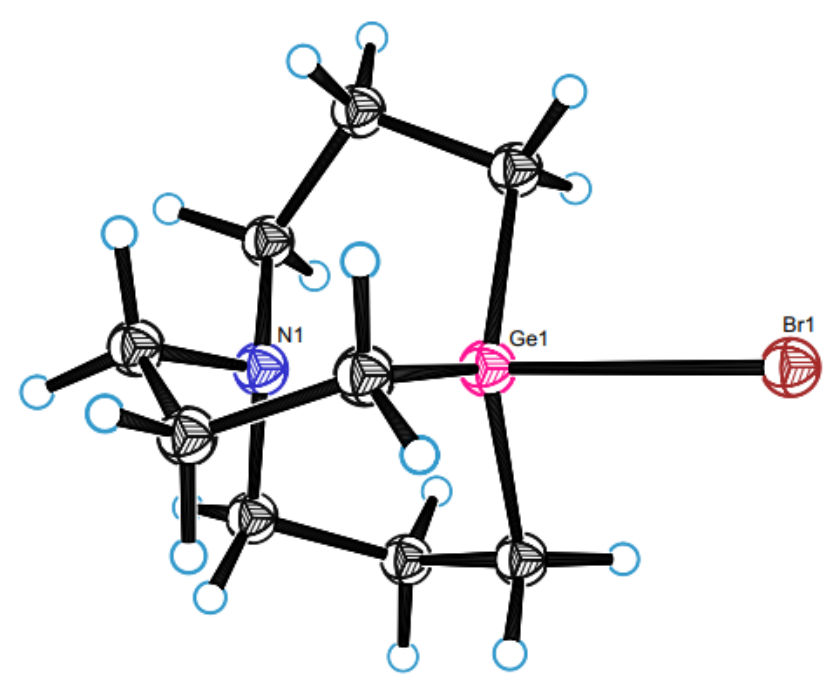




\subsubsection{Characterization data of cross-coupling products}<smiles>CCCCCCc1ccc(C#N)cc1</smiles>

4-hexylbenzonitrile (b2). Pd(dba) ${ }_{2}(1.2 \mathrm{mg}, 0.002 \mathrm{mmol}, 2 \mathrm{~mol} \%)$, ligand $\mathrm{L}_{10}$ (4.8 $\left.\mathrm{mg}, 0.006 \mathrm{mmol}, 6 \mathrm{~mol} \%\right)$, 4-bromobenzonitrile (18.2 mg, $\left.0.1 \mathrm{mmol}, 1 \mathrm{eq}\right)$ and the $n$ hexyl-Ge (a1) $(35.8 \mathrm{mg}, 0.12 \mathrm{mmol}, 1.2 \mathrm{eq})$ were weighed and transferred to a screw-cap tube with stir bar. The tube was evacuated and backfilled three times with argon, then $\mathrm{CH}_{3} \mathrm{CN}(0.5 \mathrm{~mL})$ was added and the screw-cap tube was sealed with a Teflon stopper and heated to $120{ }^{\circ} \mathrm{C}$ for 16 hours. At the end of the reaction, the reaction mixture was cooled to room temperature and the crude product was purified by preparative TLC as colorless oil (using petroleum ether/EtOAc $=$ 50/1 as eluent, $\mathrm{R}_{\mathrm{f}}=0.6,97 \% .18 .1 \mathrm{mg}$ ). $81 \%$ recovery of $\mathbf{G e B r}$ was obtained following the general procedure. ${ }^{1} \mathbf{H}$ NMR $\left(\mathbf{4 0 0} \mathbf{~ M H z}, \mathbf{C D C l}_{3}\right) \delta 7.56(\mathrm{~d}, J=7.8 \mathrm{~Hz}, 2 \mathrm{H}), 7.27(\mathrm{~d}, J=7.4 \mathrm{~Hz}$, 2H), $2.66(\mathrm{t}, J=7.7 \mathrm{~Hz}, 2 \mathrm{H}), 1.57-1.63(\mathrm{~m}, 2 \mathrm{H}), 1.22-1.37(\mathrm{~m}, 6 \mathrm{H}), 0.88(\mathrm{t}, J=6.0 \mathrm{~Hz}, 3 \mathrm{H}) .{ }^{13} \mathrm{C}$ NMR (101 MHz, $\left.\mathbf{C D C l}_{3}\right) \delta 148.7,132.2,129.3,119.3,109.6,36.2,31.7,31.1,29.0,22.7,14.2$. HRMS (ESI) Calcd for $\left[\mathrm{C}_{13} \mathrm{H}_{18} \mathrm{~N}\right]^{+}[\mathrm{M}+\mathrm{H}]^{+}:$188.1439; Found: 188.1440 .<smiles>CCCCCCc1ccc([N+](=O)[O-])cc1</smiles>

1-hexyl-4-nitrobenzene (b3). $\operatorname{Pd}(\mathrm{dba})_{2}(1.2 \mathrm{mg}, 0.002 \mathrm{mmol}, 2 \mathrm{~mol} \%)$,

ligand $\mathrm{L}_{10}$ (4.8 mg, $\left.0.006 \mathrm{mmol}, 6 \mathrm{~mol} \%\right)$, 1-bromo-4-nitrobenzene (20.2 mg, $\left.0.1 \mathrm{mmol}, 1 \mathrm{eq}\right)$ and the $n$ hexyl-Ge (a1) (35.8 mg, $0.12 \mathrm{mmol}, 1.2 \mathrm{eq}$ ) were weighed and transferred to a screw-cap tube with stir bar. The tube was evacuated and backfilled three times with argon, then $\mathrm{CH}_{3} \mathrm{CN}(0.5$ $\mathrm{mL}$ ) was added and the screw-cap tube was sealed with a Teflon stopper and heated to $120^{\circ} \mathrm{C}$ for 16 hours. At the end of the reaction, the reaction mixture was cooled to room temperature and the crude product was purified by preparative TLC as colorless oil (using petroleum ether/EtOAc = 50/1 as eluent, $\mathrm{R}_{\mathrm{f}}=0.6,95 \% .19 .6 \mathrm{mg}$ ). $85 \%$ recovery of $\boldsymbol{G e B r}$ was obtained following the general procedure. ${ }^{1} \mathbf{H}$ NMR (400 $\left.\mathbf{~ M H z}, \mathbf{C D C l}_{3}\right) \delta 8.14(\mathrm{~d}, J=8.7 \mathrm{~Hz}, 2 \mathrm{H}), 7.32(\mathrm{~d}, J=8.6 \mathrm{~Hz}$, 2H), $2.71(\mathrm{t}, J=8.0 \mathrm{~Hz}, 2 \mathrm{H}), 1.71-1.55(\mathrm{~m}, 2 \mathrm{H}), 1.40-1.23(\mathrm{~m}, 6 \mathrm{H}), 0.88(\mathrm{t}, J=6.9 \mathrm{~Hz}, 3 \mathrm{H})$. ${ }^{13} \mathbf{C}$ NMR (101 MHz, $\left.\mathbf{C D C l}_{3}\right) \delta 151.0,146.4,129.3,123.7,36.0,31.7,31.1,29.0,22.7,14.2$. HRMS (ESI) Calcd for $\mathrm{C}_{12} \mathrm{H}_{18} \mathrm{NO}_{2}[\mathrm{M}+\mathrm{H}]^{+}:$208.1338; Found: 208.1336.<smiles>CCCCCCc1ccc(OC)cc1</smiles>

1-hexyl-4-methoxybenzene (b4). $\mathrm{Pd}(\mathrm{dba})_{2}(1.2 \mathrm{mg}, 0.002 \mathrm{mmol}, 2$ mol\%), ligand $\mathrm{L}_{10}(4.8 \mathrm{mg}, 0.006 \mathrm{mmol}, 6 \mathrm{~mol} \%$ ), 4-bromoanisole (18.7 mg, $0.1 \mathrm{mmol}, 1 \mathrm{eq}$ ) and the $n$ hexyl-Ge (a1) $(35.8 \mathrm{mg}, 0.12 \mathrm{mmol}, 1.2 \mathrm{eq})$ were weighed and transferred to a screw-cap tube with stir bar. The tube was evacuated and backfilled three times with argon, then $\mathrm{CH}_{3} \mathrm{CN}(0.5$ $\mathrm{mL}$ ) was added and the screw-cap tube was sealed with a Teflon stopper and heated to $120^{\circ} \mathrm{C}$ for 16 hours. At the end of the reaction, the reaction mixture was cooled to room temperature and the crude product was purified by preparative TLC as colorless oil (using petroleum ether/EtOAc $=$ 50/1 as eluent, $\mathrm{R}_{\mathrm{f}}=0.6,96 \% .18 .4 \mathrm{mg}$ ). $78 \%$ recovery of $\mathbf{G e B r}$ was obtained following the general procedure. ${ }^{1} \mathbf{H}$ NMR $\left(\mathbf{4 0 0} \mathbf{~ M H z}, \mathbf{C D C l}_{3}\right) \delta 7.09(\mathrm{~d}, J=8.3 \mathrm{~Hz}, 2 \mathrm{H}), 6.82(\mathrm{~d}, J=8.2 \mathrm{~Hz}$, 2H), $3.79(\mathrm{~s}, 3 \mathrm{H}), 2.54(\mathrm{t}, J=7.7 \mathrm{~Hz}, 2 \mathrm{H}), 1.69-1.51(\mathrm{~m}, 2 \mathrm{H}), 1.25-1.37(\mathrm{~m}, 6 \mathrm{H}), 0.88(\mathrm{t}, J=$ $6.9 \mathrm{~Hz}, 3 \mathrm{H}) .{ }^{13} \mathbf{C}$ NMR (101 MHz, $\left.\mathbf{C D C l}_{3}\right) \delta 157.7,135.2,129.4,113.8,55.4,35.2,31.9,29.1$, 22.8, 14.3. HRMS (ESI) Calcd for $\left[\mathrm{C}_{13} \mathrm{H}_{21} \mathrm{O}\right]^{+}[\mathrm{M}+\mathrm{H}]^{+}:$193.1592; Found: 193.1595. 
<smiles>CCCCCCc1ccc(C(=O)OC)o1</smiles>

Methyl 5-hexylfuran-2-carboxylate (b5). $\mathrm{Pd}(\mathrm{dba})_{2}(1.2 \mathrm{mg}, 0.002$

mmol, $2 \mathrm{~mol} \%$ ), ligand $\mathrm{L}_{10}(4.8 \mathrm{mg}, 0.006 \mathrm{mmol}, 6 \mathrm{~mol} \%)$, methyl 5-bromo-2-furoate (20.5 mg, $0.1 \mathrm{mmol}, 1 \mathrm{eq})$ and the $n$ hexyl-Ge (a1) $(35.8 \mathrm{mg}, 0.12 \mathrm{mmol}, 1.2 \mathrm{eq})$ were weighed and transferred to a screw-cap tube with stir bar. The tube was evacuated and backfilled three times with argon, then $\mathrm{CH}_{3} \mathrm{CN}(0.5 \mathrm{~mL})$ was added and the screw-cap tube was sealed with a Teflon stopper and heated to $120{ }^{\circ} \mathrm{C}$ for 16 hours. At the end of the reaction, the reaction mixture was cooled to room temperature and the crude product was purified by preparative TLC as colorless oil (using petroleum ether/EtOAc $=50 / 1$ as eluent, $\mathrm{R}_{\mathrm{f}}=0.4,90 \% .18 .9 \mathrm{mg}$ ). $85 \%$ recovery of $\boldsymbol{G e B r}$ was obtained following the general procedure. ${ }^{1} \mathbf{H}$ NMR $\left(400 \mathbf{~ M H z}, \mathbf{C D C l}_{3}\right) \delta 7.10(\mathrm{~d}, J=3.4 \mathrm{~Hz}$, $1 \mathrm{H}), 6.12(\mathrm{~d}, J=3.4 \mathrm{~Hz}, 1 \mathrm{H}), 3.87(\mathrm{~s}, 3 \mathrm{H}), 2.68(\mathrm{t}, J=7.7 \mathrm{~Hz}, 2 \mathrm{H}), 1.71-1.63(\mathrm{~m}, 2 \mathrm{H}), 1.43-$ $1.23(\mathrm{~m}, 6 \mathrm{H}), 0.95-0.83(\mathrm{~m}, 3 \mathrm{H}) .{ }^{13} \mathbf{C}$ NMR (101 MHz, $\left.\mathbf{C D C l}_{3}\right) \delta 161.8,159.4,142.9,119.4$, 107.6, 51.8, 31.6, 28.9, 28.4, 27.8, 22.6, 14.1. HRMS (ESI) Calcd for $\left[\mathrm{C}_{12} \mathrm{H}_{19} \mathrm{O}_{3}\right]^{+}[\mathrm{M}+\mathrm{H}]^{+}$: 211.1334; Found: 211.1332.<smiles>Cc1ccc2cc(CCCCCN)ccc2n1</smiles>

5-(6-methylquinolin-6-yl)pentanenitrile (b6). $\mathrm{Pd}(\mathrm{dba})_{2} \quad(1.2 \mathrm{mg}$, $0.002 \mathrm{mmol}, 2 \mathrm{~mol} \%)$, ligand $\mathrm{L}_{10}(4.8 \mathrm{mg}, 0.006 \mathrm{mmol}, 6 \mathrm{~mol} \%)$, 6-bromo-2-methylquinoline (22.2 $\mathrm{mg}, 0.1 \mathrm{mmol}, 1 \mathrm{eq})$ and $\mathbf{a} 7(35.5 \mathrm{mg}, 0.12 \mathrm{mmol}, 1.2 \mathrm{eq})$ were weighed and transferred to a screw-cap tube with stir bar. The tube was evacuated and backfilled three times with argon, then $\mathrm{CH}_{3} \mathrm{CN}(0.5 \mathrm{~mL})$ was added and the screw-cap tube was sealed with a Teflon stopper and heated to $120{ }^{\circ} \mathrm{C}$ for 16 hours. At the end of the reaction, the reaction mixture was cooled to room temperature and the crude product was purified by preparative TLC as colorless oil (using petroleum ether/EtOAc $=5 / 1$ as eluent, $\left.\mathrm{R}_{\mathrm{f}}=0.4,99 \% .22 \mathrm{mg}\right) .{ }^{\mathbf{1}} \mathbf{H} \mathbf{~ N M R}\left(\mathbf{4 0 0} \mathbf{~ M H z}, \mathbf{C D C l}_{3}\right) \delta$ $7.97(\mathrm{dd}, J=11.2,8.9 \mathrm{~Hz}, 2 \mathrm{H}), 7.57-7.45(\mathrm{~m}, 2 \mathrm{H}), 7.28(\mathrm{~s}, 1 \mathrm{H}), 2.82(\mathrm{t}, J=7.5 \mathrm{~Hz}, 2 \mathrm{H}), 2.73$ (s, $3 \mathrm{H}), 2.37(\mathrm{t}, J=7.0 \mathrm{~Hz}, 2 \mathrm{H}), 1.95-1.81(\mathrm{~m}, 2 \mathrm{H}), 1.75-1.68(\mathrm{~m}, 2 \mathrm{H}) .{ }^{13} \mathbf{C}$ NMR (101 MHz, $\left.\mathbf{C D C l}_{3}\right) \delta 158.5,146.8,138.7,135.9,130.7,128.8,126.6,126.1,122.2,119.6,34.9,30.1,25.4$, 24.9, 17.2. HRMS (ESI) Calcd for $\left[\mathrm{C}_{15} \mathrm{H}_{17} \mathrm{~N}_{2}\right]^{+}[\mathrm{M}+\mathrm{H}]^{+}: 225.1392$; Found: 225.1393 .

We scaled up the cross-coupling reaction to $1.5 \mathrm{mmol}$ and then synthesized a1 using recovered

$\boldsymbol{G e} \mathrm{Br}$ and applied it in model reaction:

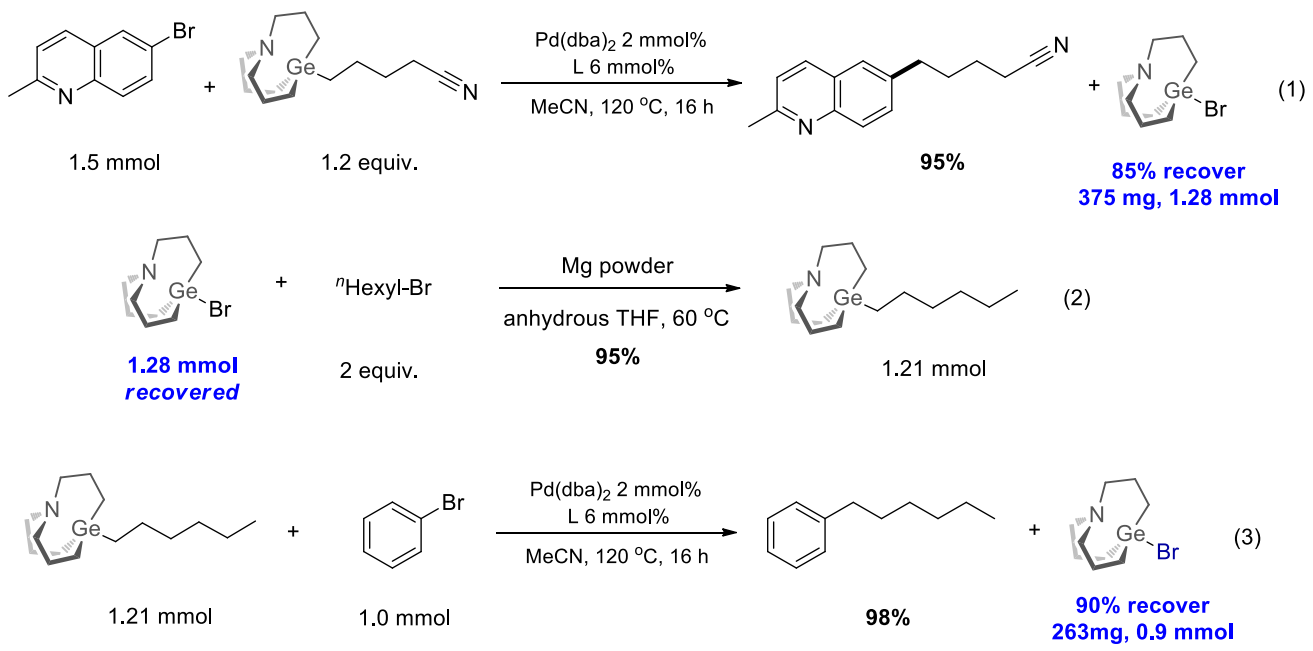

As equation (1), $\mathrm{Pd}(\mathrm{dba})_{2}(18 \mathrm{mg}, 0.03 \mathrm{mmol}, 2 \mathrm{~mol} \%)$, ligand $\mathrm{L}_{10}(72 \mathrm{mg}, 0.09 \mathrm{mmol}, 6 \mathrm{~mol} \%)$, 
6-bromo-2-methylquinoline (333 mg, $1.5 \mathrm{mmol}, 1 \mathrm{eq})$ and $\mathbf{a} 7(532 \mathrm{mg}, 1.8 \mathrm{mmol}, 1.2 \mathrm{eq})$ were weighed and transferred to a $25 \mathrm{~mL}$ screw-cap tube with stir bar. The tube was evacuated and backfilled three times with argon, then $\mathrm{CH}_{3} \mathrm{CN}(7.5 \mathrm{~mL})$ was added and the screw-cap tube was sealed with a Teflon stopper and heated to $120{ }^{\circ} \mathrm{C}$ for 16 hours. At the end of the reaction, the reaction mixture was cooled to room temperature and then the tube was settled at $-20{ }^{\circ} \mathrm{C}$ for 2 hours. Most of $\mathrm{GeBr}$ was precipitated from the solution which could be recovered through filtration, and filtrate was concentrated to provide the crude product. The crude product was purified by silica gel column chromatography (300-400 mesh) as thick oil (using petroleum ether/EtOAc $=5 / 1$ as eluent, $\mathrm{R}_{\mathrm{f}}=0.4,95 \% .319 \mathrm{mg}$ ). The solid obtained by filtration was redissolved in dichloromethane $(20 \mathrm{~mL})$, then filtered to remove palladium black. Filtrate was concentrated to provide the recovered $\mathrm{GeBr}$ which could be further purified by recrystallization from THF (375 mg, 85\%).

As equation (2), in a $25 \mathrm{~mL}$ schlenk tube equipped with a tefloncoated magnetic stir bar, the 5-bromo-1-aza-5-germabicyclo[3.3.3] undecane (375 mg, $1.28 \mathrm{mmol}, 1.0 \mathrm{eq})$ and $\mathrm{Mg}$ powder (93.4 mg, $3.84 \mathrm{mmol}, 3 \mathrm{eq}$ ) were weighed and transferred. The tube was evacuated and backfilled three times with argon, then anhydrous THF $(6.4 \mathrm{~mL})$ and 1-bromohexane $(423 \mathrm{mg}, 2.56 \mathrm{mmol}, 2$ eq) were added and heated at $60{ }^{\circ} \mathrm{C}$ for 8 hours. Then the mixture was concentrated and extracted with petroleum ether $/ \mathrm{H}_{2} \mathrm{O}$. The organic phase was separated and dried over $\mathrm{MgSO}_{4}$ and concentrated in vacuo to afford the hexyl carbagermatrane a1 which could be purified by silica gel column chromatography (361 mg, 95\%).

As equation (3), $\mathrm{Pd}(\mathrm{dba})_{2}\left(12 \mathrm{mg}, 0.02 \mathrm{mmol}, 2 \mathrm{~mol} \%\right.$ ), ligand $\mathrm{L}_{10}$ (48 mg, $0.06 \mathrm{mmol}, 6 \mathrm{~mol} \%$ ), bromobenzene (157 mg, $1.0 \mathrm{mmol}, 1 \mathrm{eq}$ ) and a1 (361 mg, $1.21 \mathrm{mmol}, 1.2 \mathrm{eq})$ were weighed and transferred to a $25 \mathrm{~mL}$ screw-cap tube with stir bar. The tube was evacuated and backfilled three times with argon, then $\mathrm{CH}_{3} \mathrm{CN}(5 \mathrm{~mL})$ was added and the screw-cap tube was sealed with a Teflon stopper and heated to $120{ }^{\circ} \mathrm{C}$ for 16 hours. At the end of the reaction, the reaction mixture was cooled to room temperature and then the tube was settled at $-20{ }^{\circ} \mathrm{C}$ for 2 hours. Most of $\boldsymbol{G e B r}$ was precipitated from the solution which could be recovered through filtration, and cyclohexylbenzene $(0.168 \mathrm{~mL}, 1 \mathrm{mmol}, 1 \mathrm{eq})$ was added to the filtrate as internal standard and then the solution was diluted by EtOAc $(20 \mathrm{~mL})$. The yield of product was determined by GC $(98 \%)$. The solid obtained by filtration was redissolved in dichloromethane $(20 \mathrm{~mL})$, then filtered to remove palladium black. Filtrate was concentrated to provide the recovered $\mathbf{G e B r}$ which could be further purified by recrystallization from THF (263 $\mathrm{mg}, 90 \%)$.<smiles>C=CCCCc1ccc(C(=O)OC)o1</smiles>

Methyl 5-(pent-4-en-1-yl)furan-2-carboxylate (b7). $\mathrm{Pd}(\mathrm{dba})_{2}(1.2 \mathrm{mg}$,

$0.002 \mathrm{mmol}, 2 \mathrm{~mol} \%$ ), ligand $\mathrm{L}_{10}(4.8 \mathrm{mg}, 0.006 \mathrm{mmol}, 6 \mathrm{~mol} \%)$, methyl 5-bromo-2-furoate (20.5 $\mathrm{mg}, 0.1 \mathrm{mmol}, 1 \mathrm{eq})$ and $\mathbf{a} 4(33.8 \mathrm{mg}, 0.12 \mathrm{mmol}, 1.2 \mathrm{eq})$ were weighed and transferred to a screw-cap tube with stir bar. The tube was evacuated and backfilled three times with argon, then $\mathrm{CH}_{3} \mathrm{CN}(0.5 \mathrm{~mL})$ was added and the screw-cap tube was sealed with a Teflon stopper and heated to $120{ }^{\circ} \mathrm{C}$ for 16 hours. At the end of the reaction, the reaction mixture was cooled to room temperature and the crude product was purified by preparative TLC as colorless oil (using petroleum ether/EtOAc $=50 / 1$ as eluent, $\left.\mathrm{R}_{\mathrm{f}}=0.4,85 \% .16 .5 \mathrm{mg}\right) .{ }^{1} \mathbf{H} \mathbf{~ N M R}\left(\mathbf{4 0 0} \mathbf{~ M H z}, \mathbf{C D C l}_{3}\right) \delta$ $7.11(\mathrm{~d}, J=3.4 \mathrm{~Hz}, 1 \mathrm{H}), 6.14(\mathrm{~d}, J=3.4 \mathrm{~Hz}, 1 \mathrm{H}), 5.85-5.75(\mathrm{~m}, 1 \mathrm{H}), 5.03(\mathrm{dd}, J=23.0,5.9 \mathrm{~Hz}$, 2H), $3.88(\mathrm{~s}, 3 \mathrm{H}), 2.71(\mathrm{t}, J=7.7 \mathrm{~Hz}, 2 \mathrm{H}), 2.11(\mathrm{q}, J=7.1 \mathrm{~Hz}, 2 \mathrm{H}), 1.86-1.71(\mathrm{~m}, 2 \mathrm{H}) .{ }^{13} \mathrm{C}$ 
NMR $\left(101 \mathrm{MHz}, \mathrm{CDCl}_{3}\right) \delta 161.3,159.4,143.0,137.9,119.4,115.5,107.9,51.9,33.2,27.7,27.0$. HRMS (ESI) Calcd for $\left[\mathrm{C}_{11} \mathrm{H}_{15} \mathrm{O}_{3}\right]^{+}[\mathrm{M}+\mathrm{H}]^{+}: 195.1021$; Found: 195.1020 .

$\mathrm{OHC}$<smiles>C/C=C\CCCCc1ccccc1</smiles>

4-(hex-5-en-1-yl)benzaldehyde (b8). Pd(dba) 2 (1.2 mg, 0.002 mmol, 2 mol\%), ligand $\mathrm{L}_{10}$ (4.8 mg, $\left.0.006 \mathrm{mmol}, 6 \mathrm{~mol} \%\right)$, 4-bromobenzaldehyde (18.5 mg, $0.1 \mathrm{mmol}, 1$ eq) and $\mathbf{a 5}$ (35.5 mg, $0.12 \mathrm{mmol}, 1.2 \mathrm{eq}$ ) were weighed and transferred to a screw-cap tube with stir bar. The tube was evacuated and backfilled three times with argon, then $\mathrm{CH}_{3} \mathrm{CN}(0.5 \mathrm{~mL})$ was added and the screw-cap tube was sealed with a Teflon stopper and heated to $120^{\circ} \mathrm{C}$ for 16 hours. At the end of the reaction, the reaction mixture was cooled to room temperature and the crude product was purified by preparative TLC as colorless oil (using petroleum ether/EtOAc $=50 / 1$ as eluent, $\left.\mathrm{R}_{\mathrm{f}}=0.5,79 \% .14 .8 \mathrm{mg}\right) .{ }^{1} \mathbf{H}$ NMR (400 $\left.\mathbf{~ M H z}, \mathbf{C D C l}_{3}\right) \delta 9.97(\mathrm{~s}, 1 \mathrm{H}), 7.80(\mathrm{~d}, J=8.1 \mathrm{~Hz}$, 2H), $7.34(\mathrm{~d}, J=8.0 \mathrm{~Hz}, 2 \mathrm{H}), 5.79(\mathrm{ddt}, J=16.9,10.1,6.7 \mathrm{~Hz}, 1 \mathrm{H}), 5.20-4.76(\mathrm{~m}, 2 \mathrm{H}), 2.70(\mathrm{t}, J$ $=8.0 \mathrm{~Hz}, 2 \mathrm{H}), 2.16-2.04(\mathrm{~m}, 2 \mathrm{H}), 1.72-1.60(\mathrm{~m}, 2 \mathrm{H}), 1.51-1.40(\mathrm{~m}, 2 \mathrm{H}) .{ }^{13} \mathbf{C}$ NMR $(101$ MHz, $\left.\mathbf{C D C l}_{3}\right) \delta 192.2,150.4,138.7,134.6,130.1,129.3,114.8,36.2,33.7,30.7,28.6$. HRMS (ESI) Calcd for $\left[\mathrm{C}_{13} \mathrm{H}_{17} \mathrm{O}\right]^{+}[\mathrm{M}+\mathrm{H}]^{+}:$: 189.1279; Found: 189.1275 .<smiles>O=Cc1coc2ccc(CCC3OCCCO3)cc2c1=O</smiles>

6-(2-(1,3-dioxan-2-yl)ethyl)-4-oxo-4H-chromene-3-carbaldehyde (b9). $\mathrm{Pd}(\mathrm{dba})_{2}(1.2 \mathrm{mg}, 0.002 \mathrm{mmol}, 2 \mathrm{~mol} \%)$, ligand $\mathrm{L}_{10}(4.8 \mathrm{mg}, 0.006 \mathrm{mmol}, 6 \mathrm{~mol} \%)$, 6-bromo-3-formylchromone ( $25.3 \mathrm{mg}, 0.1 \mathrm{mmol}, 1 \mathrm{eq}$ ) and $\mathbf{a 6}$ (39.5 mg, $0.12 \mathrm{mmol}, 1.2 \mathrm{eq}$ ) were weighed and transferred to a screw-cap tube with stir bar. The tube was evacuated and backfilled three times with argon, then $\mathrm{CH}_{3} \mathrm{CN}(0.5 \mathrm{~mL})$ was added and the screw-cap tube was sealed with a Teflon stopper and heated to $120{ }^{\circ} \mathrm{C}$ for 16 hours. At the end of the reaction, the reaction mixture was cooled to room temperature and the crude product was purified by preparative TLC as colorless oil (using petroleum ether/EtOAc $=8 / 1$ as eluent, $\mathrm{R}_{\mathrm{f}}=0.3,75 \% .21 .6 \mathrm{mg}$ ). ${ }^{1} \mathbf{H}$ NMR (400 MHz, CDCl $) \delta 10.39(\mathrm{~s}, 1 \mathrm{H}), 8.54(\mathrm{~s}, 1 \mathrm{H}), 8.11(\mathrm{~d}, J=1.8 \mathrm{~Hz}, 1 \mathrm{H}), 7.59$ (dd, $J=8.6,2.0$ $\mathrm{Hz}, 1 \mathrm{H}), 7.47(\mathrm{~d}, J=8.6 \mathrm{~Hz}, 1 \mathrm{H}), 4.53(\mathrm{t}, J=5.1 \mathrm{~Hz}, 1 \mathrm{H}), 4.12(\mathrm{dd}, J=11.4,4.8 \mathrm{~Hz}, 2 \mathrm{H}), 3.76$ $(\mathrm{dt}, J=12.0,6.1 \mathrm{~Hz}, 2 \mathrm{H}), 2.87(\mathrm{t}, J=8.0 \mathrm{~Hz}, 2 \mathrm{H}), 2.17-2.00(\mathrm{~m}, 1 \mathrm{H}), 2.01-1.92(\mathrm{~m}, 2 \mathrm{H}), 1.36$ $(\mathrm{d}, J=13.5 \mathrm{~Hz}, 1 \mathrm{H}) .{ }^{13} \mathbf{C}$ NMR (101 MHz, $\left.\mathbf{C D C l}_{3}\right) \delta 188.9,176.2,160.7,154.8,141.0,135.5$, 125.2, 125.2, 120.3, 118.7, 101.0, 67.0, 36.4, 29.6, 25.8. HRMS (ESI) Calcd for $\left[\mathrm{C}_{16} \mathrm{H}_{16} \mathrm{O} \mathrm{O}_{5} \mathrm{Na}\right]^{+}$ $[\mathrm{M}+\mathrm{Na}]^{+}:$311.0859; Found: 311.0859 .

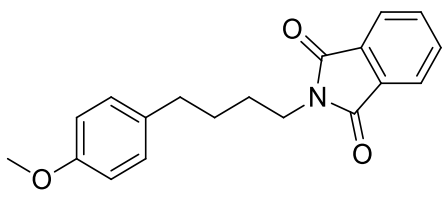

2-(4-(4-methoxyphenyl)butyl)isoindoline-1,3-dione (b10).

$\mathrm{Pd}(\mathrm{dba})_{2}(1.2 \mathrm{mg}, 0.002 \mathrm{mmol}, 2 \mathrm{~mol} \%)$, ligand $\mathrm{L}_{10}(4.8 \mathrm{mg}, 0.006 \mathrm{mmol}, 6 \mathrm{~mol} \%)$, 4-bromoanisole (18.7 mg, $0.1 \mathrm{mmol}, 1 \mathrm{eq})$ and $\mathbf{a 8}$ (49.9 mg, $0.12 \mathrm{mmol}, 1.2 \mathrm{eq})$ were weighed and transferred to a screw-cap tube with stir bar. The tube was evacuated and backfilled three times with argon, then $\mathrm{CH}_{3} \mathrm{CN}(0.5 \mathrm{~mL})$ was added and the screw-cap tube was sealed with a Teflon stopper and heated to $120{ }^{\circ} \mathrm{C}$ for 16 hours. At the end of the reaction, the reaction mixture was cooled to room temperature and the crude product was purified by preparative TLC as white solid (using petroleum ether $/$ EtOAc $=5 / 1$ as eluent, $\left.\mathrm{R}_{\mathrm{f}}=0.3,97 \% .30 \mathrm{mg}\right) .{ }^{1} \mathbf{H} \mathbf{~ N M R}(\mathbf{4 0 0} \mathbf{~ M H z}$, 
$\left.\mathbf{C D C l}_{3}\right) \delta 7.88-7.76(\mathrm{~m}, 2 \mathrm{H}), 7.74-7.62(\mathrm{~m}, 2 \mathrm{H}), 7.08(\mathrm{~d}, J=8.5 \mathrm{~Hz}, 2 \mathrm{H}), 6.80(\mathrm{~d}, J=8.6 \mathrm{~Hz}$, 2H), $3.77(\mathrm{~s}, 3 \mathrm{H}), 3.70(\mathrm{t}, J=7.0 \mathrm{~Hz}, 2 \mathrm{H}), 2.59$ (t, $J=7.4 \mathrm{~Hz}, 2 \mathrm{H}), 1.59-1.74(\mathrm{~m}, 4 \mathrm{H}) .{ }^{13} \mathbf{C}$ NMR (101 MHz, CDCl $\mathbf{3}) \delta 168.5,157.8,134.2,134.0,132.2,129.4,123.3,113.8,55.3,37.9,34.5,29.0$, 28.2. HRMS (ESI) Calcd for $\left[\mathrm{C}_{19} \mathrm{H}_{20} \mathrm{NO}_{3}\right]^{+}[\mathrm{M}+\mathrm{H}]^{+}: 310.1443$; Found: 310.1446.<smiles>COc1ccc(C[C@H](NC(C)=O)C(C)(C)C)cc1</smiles>

(S)-methyl

2-((tert-butoxycarbonyl)amino)-3-(4-methoxyphenyl)propanoate (b11). $\operatorname{Pd}(\mathrm{dba})_{2} \quad(1.2 \mathrm{mg}$, $0.002 \mathrm{mmol}, 2 \mathrm{~mol} \%$ ), ligand $\mathrm{L}_{10}(4.8 \mathrm{mg}, 0.006 \mathrm{mmol}, 6 \mathrm{~mol} \%)$, 4-bromoanisole (18.7 mg, 0.1 mmol, $1 \mathrm{eq}$ ) and $\mathbf{a 1 2}(49.8 \mathrm{mg}, 0.12 \mathrm{mmol}, 1.2 \mathrm{eq})$ were weighed and transferred to a screw-cap tube with stir bar. The tube was evacuated and backfilled three times with argon, then $\mathrm{CH}_{3} \mathrm{CN}(0.5$ $\mathrm{mL}$ ) was added and the screw-cap tube was sealed with a Teflon stopper and heated to $120^{\circ} \mathrm{C}$ for 16 hours. At the end of the reaction, the reaction mixture was cooled to room temperature and the crude product was purified by preparative TLC as colorless oil (using petroleum ether/EtOAc $=$ $15 / 1$ as eluent, $\left.\mathrm{R}_{\mathrm{f}}=0.5,68 \% .21 \mathrm{mg}\right) .{ }^{1} \mathbf{H}$ NMR $\left(\mathbf{4 0 0} \mathbf{~ M H z}, \mathbf{C D C l}_{3}\right) \delta 7.04(\mathrm{~d}, J=8.3 \mathrm{~Hz}, 2 \mathrm{H})$, $6.83(\mathrm{~d}, J=8.4 \mathrm{~Hz}, 2 \mathrm{H}), 4.97(\mathrm{~d}, J=7.8 \mathrm{~Hz}, 1 \mathrm{H}), 4.54(\mathrm{dd}, J=13.4,6.0 \mathrm{~Hz}, 1 \mathrm{H}), 3.78(\mathrm{~s}, 3 \mathrm{H})$, 3.71 (s, 3H), $3.08-2.97$ (m, 2H), 1.42 (s, 9H). $\left.{ }^{13} \mathbf{C ~ N M R ~ ( 1 0 1 ~ M H z , ~} \mathbf{C D C l}_{3}\right) \delta$ 172.6, 158.7, 155.2, 130.4, 128.0, 114.1, 80.0, 55.3, 54.6, 52.3, 37.6, 28.4. HRMS (ESI) Calcd for $\left[\mathrm{C}_{16} \mathrm{H}_{23} \mathrm{NO}_{5} \mathrm{Na}\right]^{+}[\mathrm{M}+\mathrm{Na}]^{+}: 332.1474$; Found: 332.1472;

\begin{tabular}{ll}
\hline Column & CHIRALCEL AD-H(ADH0CE-TD152) \\
\hline Column size & $0.46 \mathrm{~cm}$ I.D. $\times 25 \mathrm{~cm} \mathrm{~L}$ \\
Injection & $2.5 \mathrm{uL}$ \\
Mobile phase & Hexane/Isopropanol $=80 / 20(\mathrm{~V} / \mathrm{V})$ \\
Flow rate & $1.0 \mathrm{~mL} / \mathrm{min}$ \\
Wave length & $\mathrm{UV} 220 \mathrm{~nm}$ \\
Temperature & $25^{\circ} \mathrm{C}$ \\
\hline
\end{tabular}

$\mathrm{mV}$

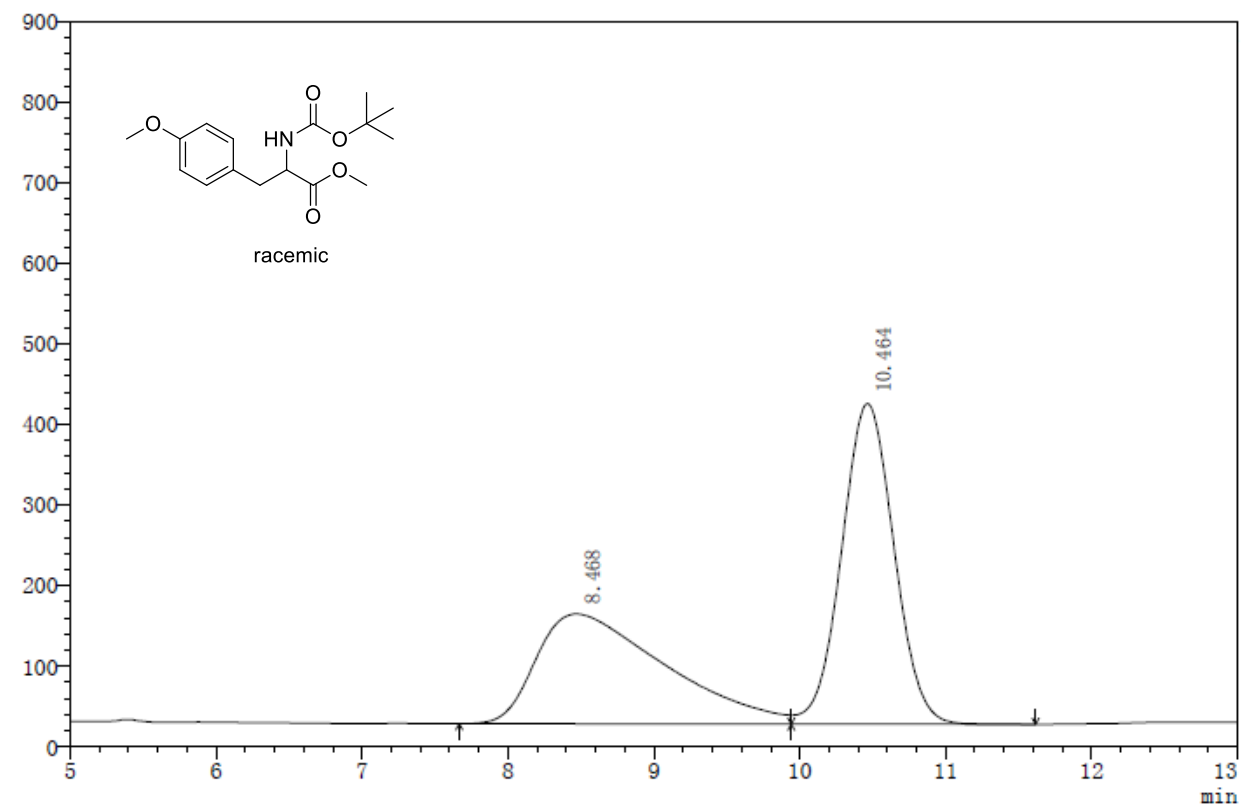

\begin{tabular}{|c|c|c|c|c|c|c|}
\hline Peak\# & Ret. Time & Area & Area\% & T.Plate\# & Tailing F. & Height \\
\hline
\end{tabular} 


\begin{tabular}{|c|c|c|c|c|c|c|}
\hline 1 & 8.468 & 8336645 & 45.652 & 414 & --- & 136249 \\
\hline 2 & 10.464 & 9924588 & 54.348 & 4025 & 1.022 & 397820 \\
\hline
\end{tabular}

$\mathrm{mV}$

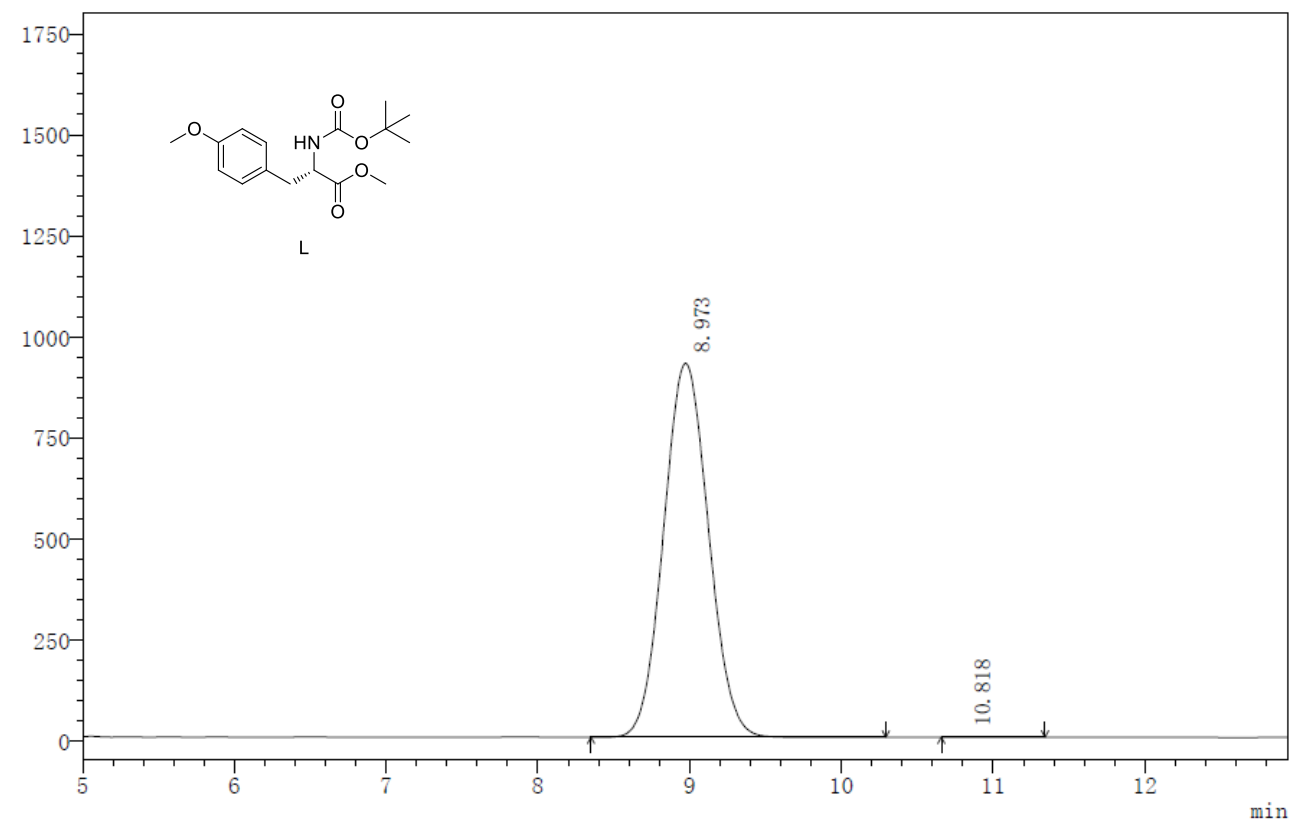

\begin{tabular}{|c|c|c|c|c|c|c|}
\hline Peak\# & Ret. Time & Area & Area\% & T.Plate\# & Tailing F. & Height \\
\hline 1 & 8.973 & 19034550 & 99.994 & 4270 & 1.061 & 925320 \\
\hline 2 & 10.818 & 1222 & 0.006 & 6587 & 2.025 & 58 \\
\hline
\end{tabular}<smiles>CC(=O)OC(=O)C(Cc1ccc(C(F)(F)F)cc1)NC(=O)c1ccc(F)cc1</smiles>

(S)-methyl

2-((tert-butoxycarbonyl)amino)-3-(4-(trifluoromethyl)phenyl)propanoate (b12). $\operatorname{Pd}(\mathrm{dba})_{2}(1.2$ $\mathrm{mg}, 0.002 \mathrm{mmol}, 2 \mathrm{~mol} \%)$, ligand $\mathrm{L}_{10}(4.8 \mathrm{mg}, 0.006 \mathrm{mmol}, 6 \mathrm{~mol} \%)$, 4-bromobenzotrifluoride $(0.014 \mathrm{~mL}, 0.1 \mathrm{mmol}, 1 \mathrm{eq})$ and $\mathbf{a 1 2}(49.8 \mathrm{mg}, 0.12 \mathrm{mmol}, 1.2 \mathrm{eq})$ were weighed and transferred to a screw-cap tube with stir bar. The tube was evacuated and backfilled three times with argon, then $\mathrm{CH}_{3} \mathrm{CN}(0.5 \mathrm{~mL})$ was added and the screw-cap tube was sealed with a Teflon stopper and heated to $120^{\circ} \mathrm{C}$ for 16 hours. At the end of the reaction, the reaction mixture was cooled to room temperature and the crude product was purified by preparative TLC as colorless oil (using petroleum ether/EtOAc $=15 / 1$ as eluent, $\left.\mathbf{R}_{\mathrm{f}}=0.5,98 \% .34 \mathrm{mg}\right) .{ }^{1} \mathbf{H} \mathbf{~ N M R}\left(\mathbf{4 0 0} \mathbf{~ M H z}, \mathbf{C D C l}_{3}\right) \delta$ $7.48(\mathrm{~d}, J=7.8 \mathrm{~Hz}, 2 \mathrm{H}), 7.18(\mathrm{~d}, J=8.5 \mathrm{~Hz}, 2 \mathrm{H}), 4.97(\mathrm{~d}, J=7.3 \mathrm{~Hz}, 1 \mathrm{H}), 4.55(\mathrm{~d}, J=6.5 \mathrm{~Hz}, 1 \mathrm{H})$, 3.65 (s, 3H), 3.07 (ddd, $J=53.3,13.6,5.7 \mathrm{~Hz}, 2 \mathrm{H}), 1.33(\mathrm{~s}, 9 \mathrm{H}) .{ }^{13} \mathbf{C}$ NMR (101 MHz, CDCl $) \delta$ 172.1, 155.1, 140.5, 129.8, 129.5 (q, $J=32.3 \mathrm{~Hz}), 125.5$ (q, $J=3.0 \mathrm{~Hz}), 124.3$ (q, $J=273.7 \mathrm{~Hz})$, 80.3, 54.4, 52.5, 38.4, 28.4. HRMS (ESI) Calcd for $\mathrm{C}_{16} \mathrm{H}_{20} \mathrm{~F}_{3} \mathrm{NO}_{4} \mathrm{Na}[\mathrm{M}+\mathrm{Na}]^{+}$: 370.1242; Found: 370.1244 ;

\begin{tabular}{ll}
\hline Column & CHIRALCEL \\
\hline Column size & $0.46 \mathrm{~cm}$ I.D. $\times 25 \mathrm{~cm} \mathrm{~L}$ \\
Injection & $2.5 \mathrm{uL}$
\end{tabular}


Mobile phase $\quad$ Hexane/Isopropanol $=90 / 10(\mathrm{~V} / \mathrm{V})$

Flow rate $\quad 0.8 \mathrm{~mL} / \mathrm{min}$

Wave length UV $220 \mathrm{~nm}$

Temperature $\quad 25^{\circ} \mathrm{C}$

$\mathrm{mV}$

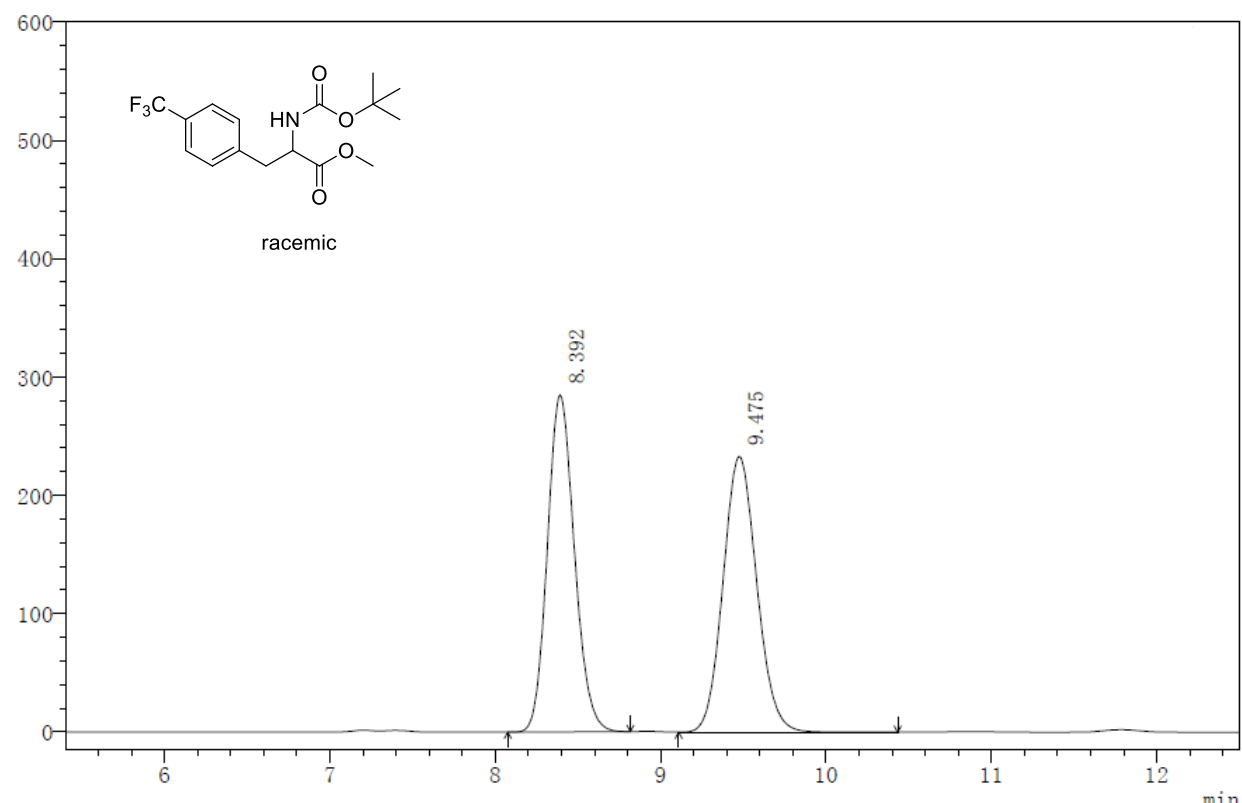

\begin{tabular}{|c|c|c|c|c|c|c|}
\hline Peak\# & Ret. Time & Area & Area\% & T.Plate\# & Tailing F. & Height \\
\hline 1 & 8.392 & 3238963 & 49.494 & 12025 & 1.140 & 284667 \\
\hline 2 & 9.475 & 3305126 & 50.506 & 10005 & 1.099 & 233038 \\
\hline
\end{tabular}

$\mathrm{mV}$

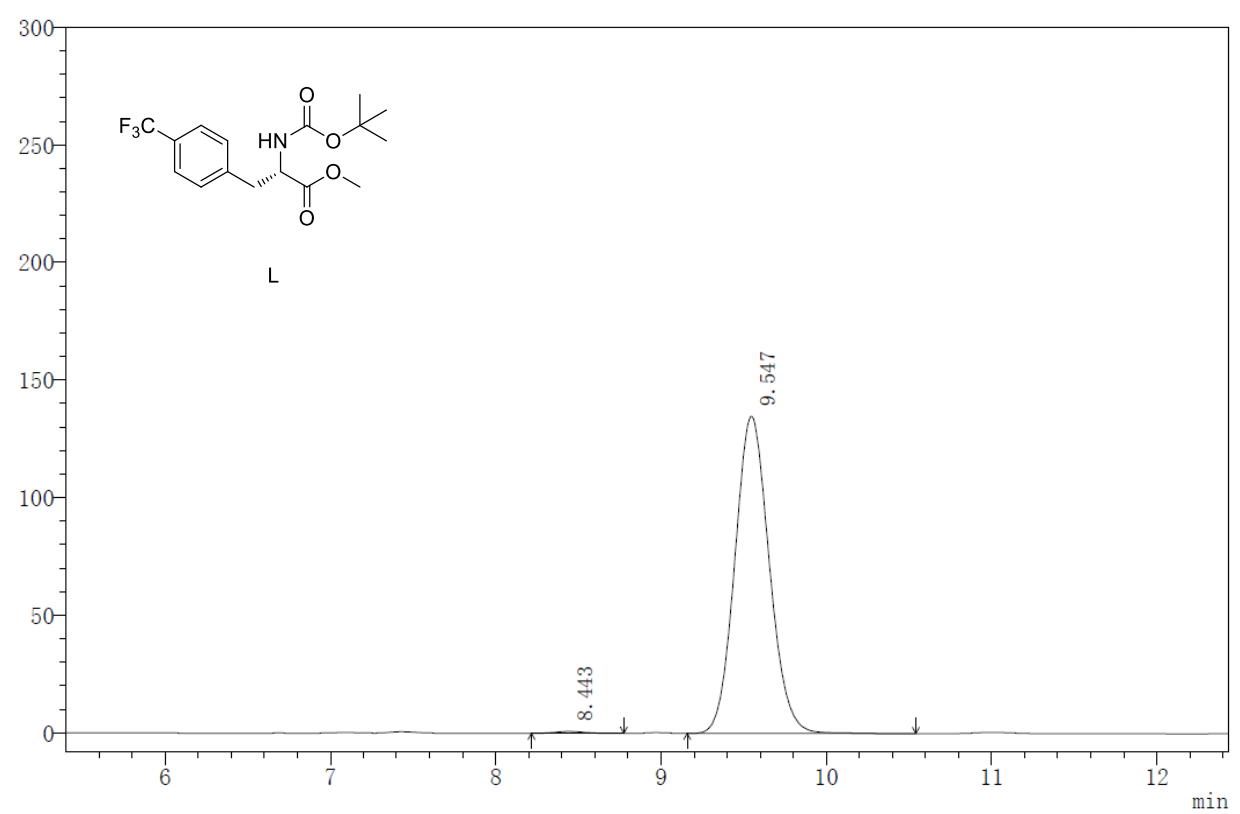

\begin{tabular}{|c|c|c|c|c|c|c|}
\hline Peak\# & Ret. Time & Area & Area\% & T.Plate\# & Tailing F. & Height \\
\hline 1 & 8.443 & 9498 & 0.484 & 11470 & 1.128 & 818 \\
\hline 2 & 9.547 & 1954514 & 99.516 & 9785 & 1.099 & 134839 \\
\hline
\end{tabular}


COAB

(S)-benzyl

2-(((benzyloxy)carbonyl)amino)-3-(3-(pentafluorosulphanyl)phenyl)propanoate

(b13).

$\mathrm{Pd}(\mathrm{dba})_{2}(1.2 \mathrm{mg}, 0.002 \mathrm{mmol}, 2 \mathrm{~mol} \%)$, ligand $\mathrm{L}_{10}(4.8 \mathrm{mg}, 0.006 \mathrm{mmol}, 6 \mathrm{~mol} \%)$, 1-bromo-3-(pentafluorosulfanyl)benzene $(0.016 \mathrm{~mL}, 0.1 \mathrm{mmol}, 1 \mathrm{eq})$ and a13 $(63.0 \mathrm{mg}, 0.12$ mmol, $1.2 \mathrm{eq})$ were weighed and transferred to a screw-cap tube with stir bar. The tube was evacuated and backfilled three times with argon, then $\mathrm{CH}_{3} \mathrm{CN}(0.5 \mathrm{~mL})$ was added and the screw-cap tube was sealed with a Teflon stopper and heated to $120{ }^{\circ} \mathrm{C}$ for 16 hours. At the end of the reaction, the reaction mixture was cooled to room temperature and the crude product was purified by preparative TLC as thick oil (using petroleum ether/EtOAc $=15 / 1$ as eluent, $R_{\mathrm{f}}=0.5$, 99\%. 51.0 mg). ${ }^{1} \mathbf{H}$ NMR (400 MHz, $\left.\mathbf{C D C l}_{3}\right) \delta 7.63-7.43(\mathrm{~m}, 3 \mathrm{H}), 7.40-7.25(\mathrm{~m}, 10 \mathrm{H}), 7.13(\mathrm{~d}$, $J=7.4 \mathrm{~Hz}, 1 \mathrm{H}), 5.35(\mathrm{~d}, J=7.5 \mathrm{~Hz}, 1 \mathrm{H}), 5.19-4.98(\mathrm{~m}, 4 \mathrm{H}), 4.69-4.73(\mathrm{~m}, 1 \mathrm{H}), 3.11-3.24(\mathrm{~m}$, 2H). ${ }^{13} \mathbf{C}$ NMR (101 MHz, $\left.\mathbf{C D C l}_{3}\right) \delta 170.9,155.6,137.1,136.2,134.8,132.6,129.0,128.8,128.7$, 128.4, 128.2, 127.0, 124.8, 67.7, 67.3, 54.7, 38.2. HRMS (ESI) Calcd for $\mathrm{C}_{24} \mathrm{H}_{22} \mathrm{~F}_{5} \mathrm{NO}_{4} \mathrm{SNa}$ $[\mathrm{M}+\mathrm{Na}]^{+}:$538.1087; Found: 538.1079;

\begin{tabular}{ll}
\hline Column & CHIRALCEL AD-H(ADHOCE-TD152) \\
\hline Column size & $0.46 \mathrm{~cm} \mathrm{I.D.} \times 25 \mathrm{~cm} \mathrm{~L}$ \\
Injection & $2.5 \mathrm{uL}$ \\
Mobile phase & Hexane/Isopropanol = 90/10 $(\mathrm{V} / \mathrm{V})$ \\
Flow rate & $0.8 \mathrm{~mL} / \mathrm{min}$ \\
Wave length & $\mathrm{UV} 220 \mathrm{~nm}$ \\
Temperature & $25^{\circ} \mathrm{C}$ \\
\hline
\end{tabular}

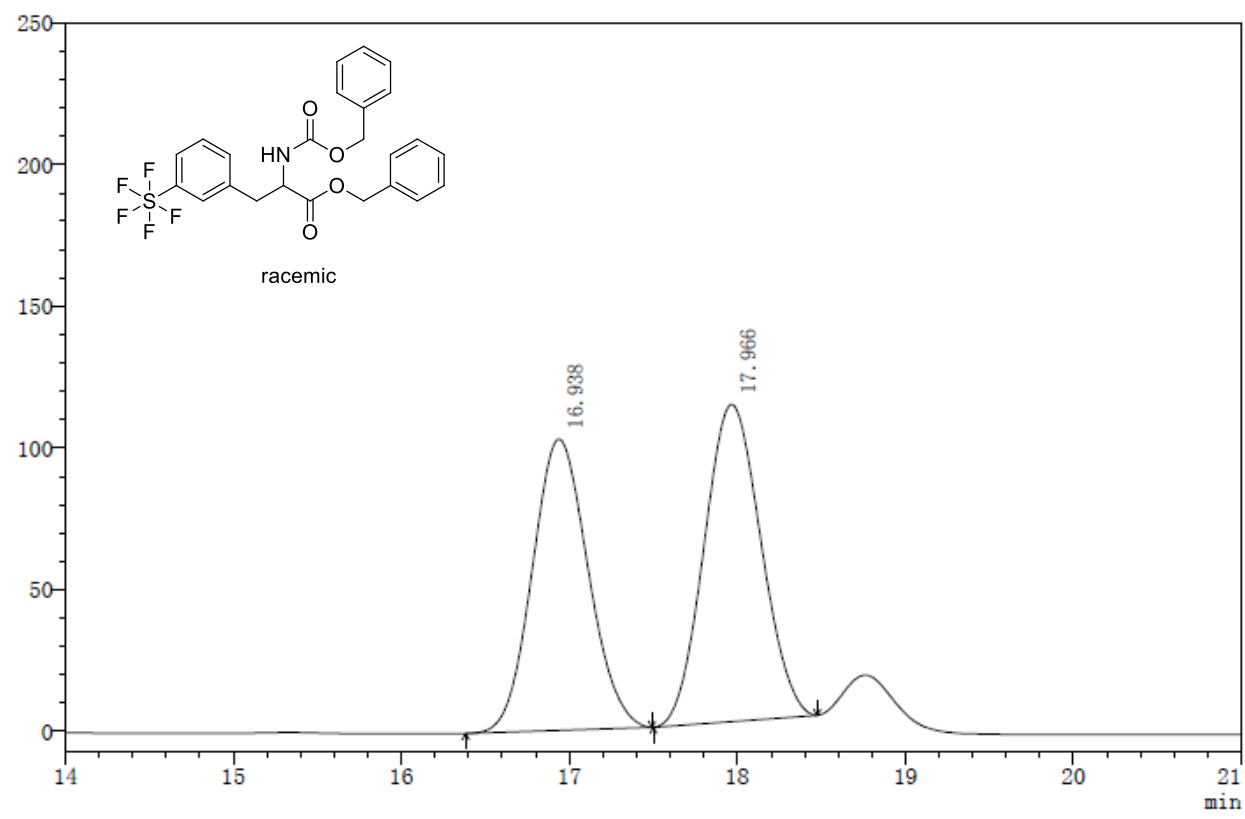

\begin{tabular}{|c|c|c|c|c|c|c|}
\hline Peak\# & Ret. Time & Area & Area\% & T.Plate\# & Tailing F. & Height \\
\hline 1 & 16.938 & 2371592 & 47.482 & 12083 & 1.091 & 102781 \\
\hline
\end{tabular}




\begin{tabular}{|l|l|l|l|l|l|l|}
\hline 2 & 17.966 & 2623074 & 52.518 & 12866 & 1.068 & 111901 \\
\hline
\end{tabular}

$\mathrm{mV}$

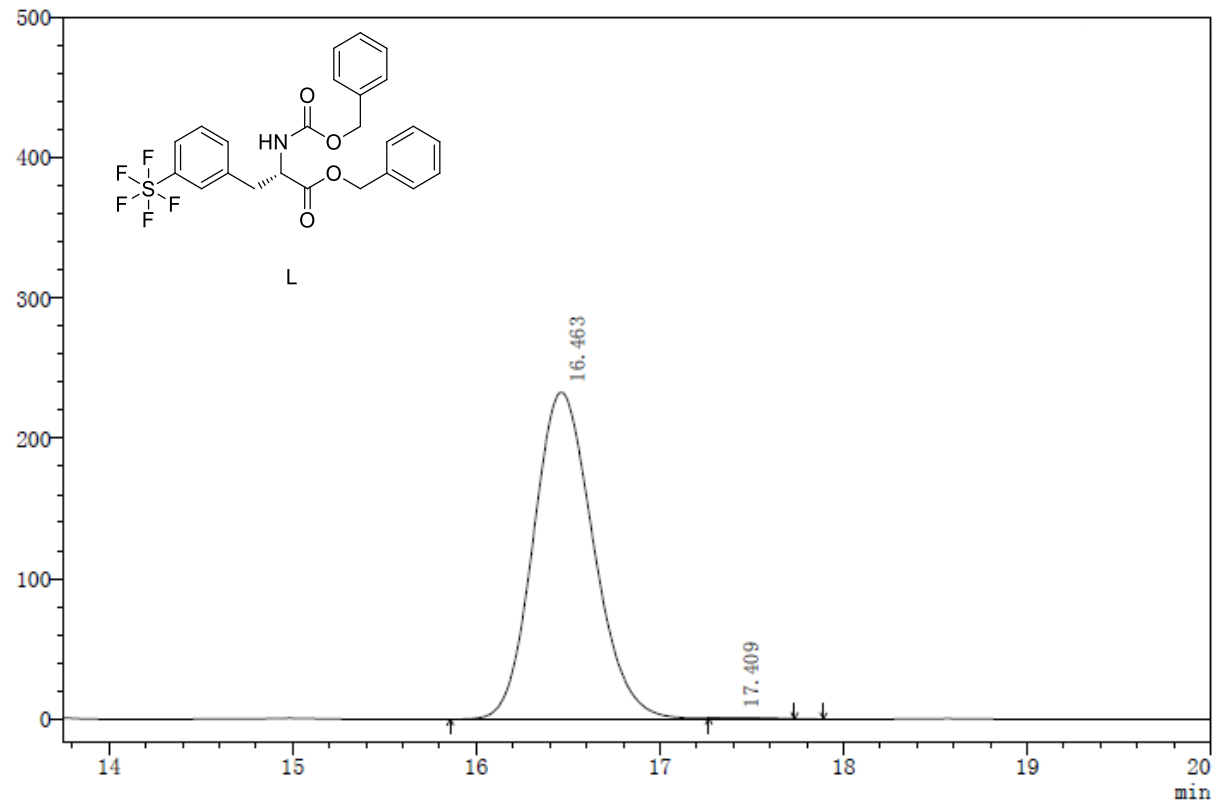

\begin{tabular}{|c|c|c|c|c|c|c|}
\hline Peak\# & Ret. Time & Area & Area\% & T.Plate\# & Tailing F. & Height \\
\hline 1 & 16.463 & 5295190 & 99.935 & 12096 & 1.149 & 232783 \\
\hline 2 & 17.409 & 3456 & 0.065 & 30771 & 1.560 & 222 \\
\hline
\end{tabular}<smiles>O=[N+]([O-])c1cccc(CCC2OCCCO2)c1</smiles>

2-(2-nitro-4-(trifluoromethyl)phenethyl)-1,3-dioxane (b14). $\mathrm{Pd}(\mathrm{dba})_{2}(1.2 \mathrm{mg}$, $0.002 \mathrm{mmol}, 2 \mathrm{~mol} \%$ ), ligand $\mathrm{L}_{10}(4.8 \mathrm{mg}, 0.006 \mathrm{mmol}, 6 \mathrm{~mol} \%)$, 4-chloro-3-nitrobenzotrifluoride ( $22.6 \mathrm{mg}, 0.1 \mathrm{mmol}, 1 \mathrm{eq}$ ) and $\mathbf{a 6}$ ( $39.5 \mathrm{mg}, 0.12 \mathrm{mmol}, 1.2 \mathrm{eq}$ ) were weighed and transferred to a screw-cap tube with stir bar. The tube was evacuated and backfilled three times with argon, then $\mathrm{CH}_{3} \mathrm{CN}(0.5 \mathrm{~mL})$ was added and the screw-cap tube was sealed with a Teflon stopper and heated to $120{ }^{\circ} \mathrm{C}$ for 16 hours. At the end of the reaction, the reaction mixture was cooled to room temperature and the crude product was purified by preparative TLC as colorless oil (using petroleum ether/EtOAc $=50 / 1$ as eluent, $\left.\mathbf{R}_{\mathrm{f}}=0.3,81 \% .26 \mathrm{mg}\right) .{ }^{1} \mathbf{H} \mathbf{~ N M R}\left(\mathbf{4 0 0} \mathbf{~ M H z}, \mathbf{C D C l}_{\mathbf{3}}\right) \delta$ $8.16(\mathrm{~s}, 1 \mathrm{H}), 7.77(\mathrm{~d}, J=8.0 \mathrm{~Hz}, 1 \mathrm{H}), 7.54(\mathrm{~d}, J=8.1 \mathrm{~Hz}, 1 \mathrm{H}), 4.57(\mathrm{t}, J=4.9 \mathrm{~Hz}, 1 \mathrm{H}), 4.10(\mathrm{dd}, J$ $=11.5,4.6 \mathrm{~Hz}, 2 \mathrm{H}), 3.75(\mathrm{t}, J=11.9 \mathrm{~Hz}, 2 \mathrm{H}), 3.08(\mathrm{t}, J=8.0 \mathrm{~Hz}, 2 \mathrm{H}), 2.16-2.01(\mathrm{~m}, 1 \mathrm{H}), 1.97$ $(\mathrm{dd}, J=13.9,6.7 \mathrm{~Hz}, 2 \mathrm{H}), 1.35(\mathrm{~d}, J=13.5 \mathrm{~Hz}, 1 \mathrm{H}) .{ }^{\mathbf{1 3}} \mathbf{C} \mathbf{~ N M R}\left(\mathbf{1 0 1} \mathbf{~ M H z}, \mathbf{C D C l}_{\mathbf{3}}\right) \delta 149.5,141.2$, 133.1, 129.9 (q, $J=34.3 \mathrm{~Hz}), 129.2(\mathrm{q}, J=3.4 \mathrm{~Hz}), 123.0(\mathrm{q}, J=273.7 \mathrm{~Hz}), 122.1(\mathrm{q}, J=3.9 \mathrm{~Hz})$, 101.0, 67.0, 35.5, 27.3, 25.8. HRMS (ESI) Calcd for $\left[\mathrm{C}_{13} \mathrm{H}_{15} \mathrm{~F}_{3} \mathrm{NO}_{4}\right]^{+}[\mathrm{M}+\mathrm{H}]^{+}: 306.0953$; Found: 306.0990 .<smiles>O=[N+]([O-])c1ccc(CCC2OCCCO2)cc1</smiles>

2-(4-nitrophenethyl)-1,3-dioxane (b15). $\mathrm{Pd}(\mathrm{dba})_{2}(1.2 \mathrm{mg}, 0.002 \mathrm{mmol}, 2$ mol\%), ligand $\mathrm{L}_{10}$ ( $\left.4.8 \mathrm{mg}, 0.006 \mathrm{mmol}, 6 \mathrm{~mol} \%\right)$, 4-chloro-nitrobenzene $(0.013 \mathrm{~mL}, 0.1 \mathrm{mmol}, 1$ eq) and $\mathbf{a 6}$ (39.5 mg, $0.12 \mathrm{mmol}, 1.2 \mathrm{eq}$ ) were weighed and transferred to a screw-cap tube with 
stir bar. The tube was evacuated and backfilled three times with argon, then $\mathrm{CH}_{3} \mathrm{CN}(0.5 \mathrm{~mL})$ was added and the screw-cap tube was sealed with a Teflon stopper and heated to $120^{\circ} \mathrm{C}$ for 16 hours. At the end of the reaction, the reaction mixture was cooled to room temperature and the crude product was purified by preparative TLC as colorless oil (using petroleum ether/EtOAc $=50 / 1$ as eluent, $\left.\mathrm{R}_{\mathrm{f}}=0.3,99 \% .23 .7 \mathrm{mg}\right) .{ }^{1} \mathbf{H}$ NMR (400 MHz, $\left.\mathbf{C D C l}_{3}\right) \delta 8.14(\mathrm{~d}, J=7.2 \mathrm{~Hz}, 2 \mathrm{H}), 7.35(\mathrm{~d}$, $J=7.5 \mathrm{~Hz}, 2 \mathrm{H}), 4.52(\mathrm{t}, J=4.9 \mathrm{~Hz}, 1 \mathrm{H}), 4.12(\mathrm{dd}, J=11.6,4.8 \mathrm{~Hz}, 2 \mathrm{H}), 3.76(\mathrm{t}, J=12.1 \mathrm{~Hz}, 2 \mathrm{H})$, $2.84(\mathrm{t}, J=8.1 \mathrm{~Hz}, 2 \mathrm{H}), 2.07-2.20(\mathrm{~m}, 1 \mathrm{H}), 1.93(\mathrm{dt}, J=9.6,6.5 \mathrm{~Hz}, 2 \mathrm{H}), 1.37(\mathrm{~d}, J=13.5 \mathrm{~Hz}$, 1H). ${ }^{13} \mathbf{C}$ NMR (101 MHz, $\left.\mathbf{C D C l}_{3}\right) \delta 149.9,146.5,129.3,123.8,100.9,67.0,36.1,30.0,25.8$. HRMS (ESI) Calcd for $\left[\mathrm{C}_{12} \mathrm{H}_{16} \mathrm{NO}_{4}\right]^{+}[\mathrm{M}+\mathrm{H}]^{+}: 238.1079$; Found: 238.1070 .

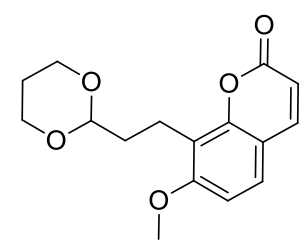

8-(2-(1,3-dioxan-2-yl)ethyl)-7-methoxy-2H-chromen-2-one

(b16).

$\mathrm{Pd}(\mathrm{dba})_{2}(1.2 \mathrm{mg}, 0.002 \mathrm{mmol}, 2 \mathrm{~mol} \%)$, ligand $\mathrm{L}_{10}(4.8 \mathrm{mg}, 0.006 \mathrm{mmol}, 6 \mathrm{~mol} \%)$, 8-bromo-7-methoxy-2H-chromen-2-one $(25.5 \mathrm{mg}, 0.1 \mathrm{mmol}, 1 \mathrm{eq})$ (prepared according to the literature $\left.{ }^{10}\right)$ and $\mathbf{a 6}(39.5 \mathrm{mg}, 0.12 \mathrm{mmol}, 1.2 \mathrm{eq})$ were weighed and transferred to a screw-cap tube with stir bar. The tube was evacuated and backfilled three times with argon, then $\mathrm{CH}_{3} \mathrm{CN}(0.5$ $\mathrm{mL}$ ) was added and the screw-cap tube was sealed with a Teflon stopper and heated to $120^{\circ} \mathrm{C}$ for 16 hours. At the end of the reaction, the reaction mixture was cooled to room temperature and the crude product. The crude product was purified by preparative TLC as thick oil (using petroleum ether/EtOAc $=5 / 1$ as eluent, $\left.\mathbf{R}_{\mathrm{f}}=0.3,80 \% .23 \mathrm{mg}\right) .{ }^{1} \mathbf{H} \mathbf{~ N M R}\left(400 \mathbf{~ M H z}, \mathbf{C D C l}_{3}\right) \delta 7.63(\mathrm{~d}, J=$ $9.4 \mathrm{~Hz}, 1 \mathrm{H}), 7.31(\mathrm{~d}, J=8.6 \mathrm{~Hz}, 1 \mathrm{H}), 6.83(\mathrm{~d}, J=8.6 \mathrm{~Hz}, 1 \mathrm{H}), 6.23(\mathrm{~d}, J=9.4 \mathrm{~Hz}, 1 \mathrm{H}), 4.60(\mathrm{t}, J$ $=5.2 \mathrm{~Hz}, 1 \mathrm{H}), 4.11(\mathrm{dd}, J=11.4,4.8 \mathrm{~Hz}, 2 \mathrm{H}), 3.91(\mathrm{~s}, 3 \mathrm{H}), 3.77(\mathrm{t}, J=11.8 \mathrm{~Hz}, 2 \mathrm{H}), 2.94(\mathrm{t}, J=$ $8.0 \mathrm{~Hz}, 2 \mathrm{H}), 2.17-2.00(\mathrm{~m}, 1 \mathrm{H}), 1.85(\mathrm{dd}, J=14.2,6.3 \mathrm{~Hz}, 2 \mathrm{H}), 1.33(\mathrm{~d}, J=13.4 \mathrm{~Hz}, 1 \mathrm{H}) .{ }^{13} \mathrm{C}$ NMR (101 MHz, $\left.\mathbf{C D C l}_{3}\right) \delta 161.6,160.6,153.1,144.0,126.6,118.0,113.0,112.9,107.3,102.4$, 67.0, 56.1, 34.1, 25.9, 17.7. HRMS (ESI) Calcd for $\left[\mathrm{C}_{16} \mathrm{H}_{18} \mathrm{O}_{5} \mathrm{Na}\right]^{+}[\mathrm{M}+\mathrm{Na}]^{+}: 313.1052$; Found: 313.1055 .<smiles>Oc1ccccc1CCCc1ccccc1</smiles>

$\mathrm{SO}_{2} \mathrm{~F}$ 2-(3-phenylpropyl)benzene-1-sulfonyl fluoride (b17). Pd(dba) $)_{2}(1.2 \mathrm{mg}, 0.002$ mmol, $2 \mathrm{~mol} \%)$, ligand $\mathrm{L}_{10}(4.8 \mathrm{mg}, 0.006 \mathrm{mmol}, 6 \mathrm{~mol} \%)$, 2-bromobenzenesulfonyl fluoride (23.9 mg, $0.1 \mathrm{mmol}, 1 \mathrm{eq}$ ) and 5-(3-phenylpropyl)-1-aza-5-germabicyclo[3.3.3] undecane (39.9 $\mathrm{mg}, 0.12 \mathrm{mmol}, 1.2 \mathrm{eq}$ ) were weighed and transferred to a screw-cap tube with stir bar. The tube was evacuated and backfilled three times with argon, then $\mathrm{CH}_{3} \mathrm{CN}(0.5 \mathrm{~mL})$ was added and the screw-cap tube was sealed with a Teflon stopper and heated to $120^{\circ} \mathrm{C}$ for 16 hours. At the end of the reaction, the reaction mixture was cooled to room temperature and the crude product was purified by preparative TLC as thick oil (using petroleum ether/EtOAc $=50 / 1$ as eluent, $R_{\mathrm{f}}=0.5$, 88\%. $24.4 \mathrm{mg}){ }^{1}{ }^{1} \mathbf{H}$ NMR (400 MHz, $\left.\mathbf{C D C l}_{3}\right) \delta 8.04(\mathrm{~d}, J=8.0 \mathrm{~Hz}, 1 \mathrm{H}), 7.66-7.62(\mathrm{~m}, 1 \mathrm{H}), 7.45$ $-7.37(\mathrm{~m}, 2 \mathrm{H}), 7.33-7.27(\mathrm{~m}, 2 \mathrm{H}), 7.23-7.16(\mathrm{~m}, 3 \mathrm{H}), 3.05(\mathrm{t}, J=8.0 \mathrm{~Hz}, 2 \mathrm{H}), 2.75(\mathrm{t}, J=7.7$ $\mathrm{Hz}, 2 \mathrm{H}), 2.10-1.92$ (m, 2H). ${ }^{13} \mathbf{C}$ NMR (101 MHz, CDCl $) \delta$ 143.6, 141.7, 135.4, 132.0, 130.4, 130.4, 128.5, 126.8, 126.1, 35.9, 33.1, 33.0. ${ }^{19} \mathbf{F}$ NMR (377 $\left.\mathbf{~ M H z , ~} \mathbf{C D C l}_{\mathbf{3}}\right) \delta 63.0$ (relative to 
$\mathrm{CFCl}_{3}$ ). HRMS (ESI) Calcd for $\left[\mathrm{C}_{15} \mathrm{H}_{15} \mathrm{FO}_{2} \mathrm{SNa}\right]^{+}[\mathrm{M}+\mathrm{Na}]^{+}: 301.0674$; Found: 301.0756

$\mathrm{NC}$<smiles>CC(C)(C)[Si](C)(C)OCCCCCCCCCc1ccc(I)cc1</smiles>

4-(8-((tert-butyldimethylsilyl)oxy)octyl)benzonitrile

(b18). $\mathrm{Pd}(\mathrm{dba})_{2}(1.2 \mathrm{mg}, 0.002 \mathrm{mmol}, 2 \mathrm{~mol} \%)$, ligand $\mathrm{L}_{10}(4.8 \mathrm{mg}, 0.006 \mathrm{mmol}, 6 \mathrm{~mol} \%)$, 4-bromobenzonitrile (18.2 $\mathrm{mg}, 0.1 \mathrm{mmol}, 1 \mathrm{eq})$ and $\mathbf{a 3}(54.8 \mathrm{mg}, 0.12 \mathrm{mmol}, 1.2 \mathrm{eq})$ were weighed and transferred to a screw-cap tube with stir bar. The tube was evacuated and backfilled three times with argon, then $\mathrm{CH}_{3} \mathrm{CN}(0.5 \mathrm{~mL})$ was added and the screw-cap tube was sealed with a Teflon stopper and heated to $120^{\circ} \mathrm{C}$ for 16 hours. At the end of the reaction, the reaction mixture was cooled to room temperature and the crude product was purified by preparative TLC as colorless oil (using petroleum ether/EtOAc $=50 / 1$ as eluent, $\mathrm{R}_{\mathrm{f}}=0.4,96 \% .33 .1 \mathrm{mg}$ ). ${ }^{1} \mathbf{H} \mathbf{~ N M R}$ $\left(400 \mathrm{MHz}, \mathbf{C D C l}_{3}\right) \delta 7.56(\mathrm{~d}, J=8.1 \mathrm{~Hz}, 2 \mathrm{H}), 7.27(\mathrm{~d}, J=8.1 \mathrm{~Hz}, 2 \mathrm{H}), 3.59(\mathrm{t}, J=6.6 \mathrm{~Hz}, 2 \mathrm{H})$, $2.65(\mathrm{t}, J=8.1 \mathrm{~Hz}, 2 \mathrm{H}), 1.68-1.57(\mathrm{~m}, 2 \mathrm{H}), 1.47-1.52(\mathrm{~m}, 2 \mathrm{H}), 1.20-1.35(\mathrm{~m}, 8 \mathrm{H}), 0.89(\mathrm{~s}$, 9H), 0.05 (s, 3H). ${ }^{13} \mathbf{C}$ NMR (101 MHz, $\left.\mathbf{C D C l}_{3}\right) \delta 148.7,132.2,129.3,119.3,109.6,63.4,36.2$, $32.9,31.1,29.5,29.4,29.2,26.1,25.9,18.5,-5.2$. HRMS (ESI) Calcd for $\left[\mathrm{C}_{21} \mathrm{H}_{36} \mathrm{NOSi}\right]^{+}[\mathrm{M}+\mathrm{H}]^{+}$: 346.2566; Found: 346.2551 .<smiles>C/C(=C\c1ccccc1)CCCCC/C(C=O)=C/c1ccccc1</smiles>

(2E,8E)-2,8-dibenzylidenenonanedial (b19). Pd(dba) 2 (2.4 mg, 0.004 mmol, $4 \mathrm{~mol} \%$ ), ligand $\mathrm{L}_{10}(9.6 \mathrm{mg}, 0.012 \mathrm{mmol}, 12 \mathrm{~mol} \%$ ), 2-bromocinnamaldehyde (42.2 $\mathrm{mg}$, $0.2 \mathrm{mmol}, 2 \mathrm{eq}$ ) and $\mathbf{a 1 7}(49.6 \mathrm{mg}, 0.1 \mathrm{mmol}, 1.0 \mathrm{eq}$ ) were weighed and transferred to a screw-cap tube with stir bar. The tube was evacuated and backfilled three times with argon, then $\mathrm{CH}_{3} \mathrm{CN}(0.5$ $\mathrm{mL}$ ) was added and the screw-cap tube was sealed with a Teflon stopper and heated to $120^{\circ} \mathrm{C}$ for 16 hours. At the end of the reaction, the reaction mixture was cooled to room temperature and the crude product was purified by preparative TLC as colorless oil (using petroleum ether/EtOAc $=$ 20/1 as eluent, $\left.\mathbf{R}_{\mathrm{f}}=0.4,75 \% .24 .9 \mathrm{mg}\right) .{ }^{1} \mathbf{H} \mathbf{N M R}\left(\mathbf{4 0 0} \mathbf{~ M H z}, \mathbf{C D C l}_{\mathbf{3}}\right) \delta 9.55(\mathrm{~s}, 2 \mathrm{H}), 7.54-7.37$ (m, 10H), 7.22 (s, 2H), $2.63-2.47$ (m, 4H), $1.60-1.42(\mathrm{~m}, 6 \mathrm{H}) .{ }^{13} \mathbf{C}$ NMR (101 MHz, CDCl $) \delta$ 195.9, 150.2, 143.2, 135.0, 129.8, 129.8, 129.0, 30.4, 28.2, 24.9. HRMS (ESI) Calcd for $\left[\mathrm{C}_{23} \mathrm{H}_{25} \mathrm{O}_{2}\right]^{+}[\mathrm{M}+\mathrm{H}]^{+}: 333.1855$; Found: 333.1858 .<smiles>C=C(CCCCN1C(=O)c2ccccc2C1=O)C(F)(F)F</smiles>

\section{2-(5-(trifluoromethyl)hex-5-en-1-yl)isoindoline-1,3-dione}

(b20).

$\operatorname{Pd}(\mathrm{dba})_{2}(1.2 \mathrm{mg}, 0.002 \mathrm{mmol}, 2 \mathrm{~mol} \%)$, ligand $\mathrm{L}_{10}(4.8 \mathrm{mg}, 0.006 \mathrm{mmol}, 6 \mathrm{~mol} \%)$, 2-bromo-3,3,3-trifluoropropene (17.5 mg, $0.1 \mathrm{mmol}, 1 \mathrm{eq})$ and $\mathbf{a 8}$ (49.9 mg, $0.12 \mathrm{mmol}, 1.2 \mathrm{eq})$ were weighed and transferred to a screw-cap tube with stir bar. The tube was evacuated and backfilled three times with argon, then $\mathrm{CH}_{3} \mathrm{CN}(0.5 \mathrm{~mL})$ was added and the screw-cap tube was sealed with a Teflon stopper and heated to $120{ }^{\circ} \mathrm{C}$ for 16 hours. At the end of the reaction, the reaction mixture was cooled to room temperature and the crude product was purified by preparative TLC as white solid (using petroleum ether/EtOAc $=5 / 1$ as eluent, $R_{\mathrm{f}}=0.4,90 \% .26 .7$ mg). ${ }^{1} \mathbf{H}$ NMR (400 MHz, $\left.\mathbf{C D C l}_{3}\right) \delta 7.88-7.82(\mathrm{~m}, 2 \mathrm{2H}), 7.75-7.69(\mathrm{~m}, 2 \mathrm{H}), 5.67$ (s, 1H), 5.32 $(\mathrm{d}, J=1.3 \mathrm{~Hz}, 1 \mathrm{H}), 3.72$ (t, $J=7.2 \mathrm{~Hz}, 2 \mathrm{H}), 2.25(\mathrm{t}, J=7.7 \mathrm{~Hz}, 2 \mathrm{H}), 1.78-1.70(\mathrm{~m}, 2 \mathrm{H}), 1.62-$ $1.54(\mathrm{~m}, 2 \mathrm{H}) .{ }^{13} \mathbf{C}$ NMR $\left(\mathbf{1 0 1} \mathbf{M H z}, \mathbf{C D C l}_{3}\right) \delta 168.5,138.1(\mathrm{q}, J=29.1 \mathrm{~Hz}), 134.1,132.2,123.8$ 
(q, $J=274.7 \mathrm{~Hz}), 123.4,118.1(\mathrm{q}, J=5.8 \mathrm{~Hz}), 37.7,29.0,28.1,24.8$. HRMS (ESI) Calcd for $\left[\mathrm{C}_{15} \mathrm{H}_{15} \mathrm{~F}_{3} \mathrm{NO}_{2}\right]^{+}[\mathrm{M}+\mathrm{H}]^{+}:$298.1055; Found: 298.1057 .

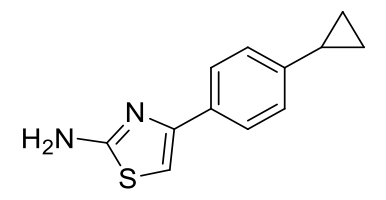

4-(4-cyclopropylphenyl)thiazol-2-amine (b21). $\mathrm{Pd}(\mathrm{dba})_{2} \quad(1.2 \mathrm{mg}$, $0.002 \mathrm{mmol}, 2 \mathrm{~mol} \%)$, ligand $\mathrm{L}_{10}(4.8 \mathrm{mg}, 0.006 \mathrm{mmol}, 6 \mathrm{~mol} \%)$, 2-amino-4-(4-bromophenyl)thiazole ( $25.5 \mathrm{mg}, 0.1 \mathrm{mmol}, 1 \mathrm{eq}$ ) and $\mathbf{a 1 6}$ (30.5 mg, $0.12 \mathrm{mmol}, 1.2$ eq) were weighed and transferred to a screw-cap tube with stir bar. The tube was evacuated and backfilled three times with argon, then $\mathrm{CH}_{3} \mathrm{CN}(0.5 \mathrm{~mL})$ was added and the screw-cap tube was sealed with a Teflon stopper and heated to $120{ }^{\circ} \mathrm{C}$ for 16 hours. At the end of the reaction, the reaction mixture was cooled to room temperature and the crude product was purified by preparative TLC as white solid (using petroleum ether/EtOAc $=6 / 1$ as eluent, $R_{f}=0.5,75 \% .16 .2$ mg). ${ }^{1} \mathbf{H}$ NMR (400 MHz, $\left.\mathbf{C D C l}_{3}\right) \delta 7.64(\mathrm{~d}, J=8.3 \mathrm{~Hz}, 2 \mathrm{H}), 7.07(\mathrm{~d}, J=8.3 \mathrm{~Hz}, 2 \mathrm{H}), 6.63$ (s, 1H), 5.29 (brs, 2H), $1.98-1.80(\mathrm{~m}, 1 \mathrm{H}), 1.03-0.91(\mathrm{~m}, 2 \mathrm{H}), 0.77-0.67(\mathrm{~m}, 2 \mathrm{H}) .{ }^{13} \mathbf{C}$ NMR (101 $\left.\mathbf{M H z}, \mathbf{C D C l}_{3}\right) \delta 167.5,151.3,143.9,132.0,131.8,127.7,126.0,125.9,102.0,15.4,9.5$. HRMS (ESI) Calcd for $\left[\mathrm{C}_{12} \mathrm{H}_{13} \mathrm{~N}_{2} \mathrm{~S}\right]^{+}[\mathrm{M}+\mathrm{H}]^{+}:$217.0799; Found: 217.0802;<smiles>Nc1nc2ccc(CCC3OCCCO3)cc2s1</smiles>

6-(2-(1,3-dioxan-2-yl)ethyl)benzo[d]thiazol-2-amine (b22). $\operatorname{Pd}(\mathrm{dba})_{2}(1.2$ $\mathrm{mg}, \quad 0.002 \mathrm{mmol}, 2 \mathrm{~mol} \%)$, ligand $\mathrm{L}_{10}(4.8 \mathrm{mg}, 0.006 \mathrm{mmol}, 6 \mathrm{~mol} \%)$, 2-amino-6-bromobenzothiazole (22.9 mg, $0.1 \mathrm{mmol}, 1 \mathrm{eq}$ ) and a6 (39.5 mg, $0.12 \mathrm{mmol}, 1.2 \mathrm{eq}$ ) were weighed and transferred to a screw-cap tube with stir bar. The tube was evacuated and backfilled three times with argon, then $\mathrm{CH}_{3} \mathrm{CN}(0.5 \mathrm{~mL})$ was added and the screw-cap tube was sealed with a Teflon stopper and heated to $120{ }^{\circ} \mathrm{C}$ for 16 hours. At the end of the reaction, the reaction mixture was cooled to room temperature and the crude product was purified by preparative TLC as colorless oil (using petroleum ether/EtOAc $=6 / 1$ as eluent, $\mathrm{R}_{\mathrm{f}}=0.3,62 \%$. $16.3 \mathrm{mg}$ ). ${ }^{1} \mathbf{H}$ NMR (400 MHz, $\left.\mathbf{C D C l}_{3}\right) \delta 7.48(\mathrm{~d}, J=8.0 \mathrm{~Hz}, 1 \mathrm{H}), 7.38(\mathrm{~s}, 1 \mathrm{H}), 6.99(\mathrm{~d}, J=8.2$ $\mathrm{Hz}, 1 \mathrm{H}), 5.49$ (brs, 2H), $4.52(\mathrm{t}, J=5.1 \mathrm{~Hz}, 1 \mathrm{H}), 4.12(\mathrm{dd}, J=11.4,4.7 \mathrm{~Hz}, 2 \mathrm{H}), 3.75(\mathrm{t}, J=12.0$ $\mathrm{Hz}, 2 \mathrm{H}), 2.78(\mathrm{t}, J=8.1 \mathrm{~Hz}, 2 \mathrm{H}), 2.18-2.02(\mathrm{~m}, 1 \mathrm{H}), 1.93(\mathrm{dd}, J=14.3,6.5 \mathrm{~Hz}, 2 \mathrm{H}), 1.34(\mathrm{~d}, J=$ $13.6 \mathrm{~Hz}, 1 \mathrm{H}) .{ }^{13} \mathbf{C}$ NMR (101 MHz, CDCl $) \delta$ 166.6, 151.9, 140.1, 128.7, 123.2, 120.8, 119.1, 101.5, 67.0, 36.9, 30.2, 26.0. HRMS (ESI) Calcd for $\left[\mathrm{C}_{13} \mathrm{H}_{17} \mathrm{~N}_{2} \mathrm{O}_{2} \mathrm{~S}\right]^{+}[\mathrm{M}+\mathrm{H}]^{+}:$265.1011; Found: 265.1013.<smiles>O=S(=O)(NCCCO)c1ccc(C2CC2)cc1</smiles>

\section{4-cyclopropyl- $N$-(3-hydroxypropyl)benzenesulfonamide (b23).}

$\operatorname{Pd}(\mathrm{dba})_{2}(1.2 \mathrm{mg}, 0.002 \mathrm{mmol}, 2 \mathrm{~mol} \%)$, ligand $\mathrm{L}_{10}(4.8 \mathrm{mg}, 0.006 \mathrm{mmol}, 6 \mathrm{~mol} \%)$, 4-bromo- $N$-(3-hydroxypropyl)benzenesulfonamide (29.4 mg, $0.1 \mathrm{mmol}, 1 \mathrm{eq}$ ) and a16 (30.5 mg, $0.12 \mathrm{mmol}, 1.2 \mathrm{eq}$ ) were weighed and transferred to a screw-cap tube with stir bar. The tube was evacuated and backfilled three times with argon, then $\mathrm{CH}_{3} \mathrm{CN}(0.5 \mathrm{~mL})$ was added and the screw-cap tube was sealed with a Teflon stopper and heated to $120^{\circ} \mathrm{C}$ for 16 hours. At the end of the reaction, the reaction mixture was cooled to room temperature and the crude product was purified by preparative TLC as white solid (using petroleum ether/EtOAc $=1 / 1$ as eluent, $R_{\mathrm{f}}=0.4$, 
77\%. $19.6 \mathrm{mg}){ }^{1}{ }^{1} \mathrm{H}$ NMR (400 MHz, $\left.\mathbf{C D C l}_{3}\right) \delta 7.73(\mathrm{~d}, J=8.2 \mathrm{~Hz}, 2 \mathrm{H}), 7.16(\mathrm{~d}, J=8.2 \mathrm{~Hz}, 2 \mathrm{H})$, 5.35 (brs, $1 \mathrm{H}), 3.71(\mathrm{t}, J=5.6 \mathrm{~Hz}, 2 \mathrm{H}), 3.06(\mathrm{t}, J=6.2 \mathrm{~Hz}, 2 \mathrm{H}), 2.34(\mathrm{~s}, 1 \mathrm{H}), 1.96-1.93(\mathrm{~m}, 1 \mathrm{H})$, $1.80-1.56(\mathrm{~m}, 2 \mathrm{H}), 1.14-0.98(\mathrm{~m}, 2 \mathrm{H}), 0.77(\mathrm{dt}, J=10.1,5.0 \mathrm{~Hz}, 2 \mathrm{H}) .{ }^{13} \mathbf{C} \mathbf{N M R}(\mathbf{1 0 1} \mathbf{~ M H z}$, $\left.\mathbf{C D C l}_{3}\right) \delta 150.0,136.4,127.2,126.1,60.5,41.0,31.6,15.7,10.6$. HRMS (ESI) Calcd for $\left[\mathrm{C}_{12} \mathrm{H}_{18} \mathrm{NO}_{3} \mathrm{~S}\right]^{+}[\mathrm{M}+\mathrm{H}]^{+}:$256.1007; Found: 256.1009 .<smiles>O=C(CCCC[C@H]1SC[C@@H]2NC(=O)N[C@@H]21)Nc1ccc(CCC2OCCCO2)cc1</smiles>

$N$-(4-(2-(1,3-dioxan-2-yl)ethyl)phenyl)-5-((3aR,4R,6aS)-2-oxohexahydro-1H-thieno[3,4-d]imi dazol-4-yl)pentanamide (b24). $\mathrm{Pd}(\mathrm{dba})_{2}(1.2 \mathrm{mg}, 0.002 \mathrm{mmol}, 2 \mathrm{~mol} \%)$, ligand $\mathrm{L}_{10}(4.8 \mathrm{mg}$, 0.006 mmol, $6 \quad \mathrm{~mol} \%)$, $\mathrm{N}$-(4-bromophenyl)-5-((3aS,4S,6aR)-2-oxohexahydro-1H-thieno[3,4-d]imidazol-4-yl)pentanamid e (39.8 mg, $0.1 \mathrm{mmol}, 1 \mathrm{eq})$ and $\mathbf{a 6}(39.5 \mathrm{mg}, 0.12 \mathrm{mmol}, 1.2 \mathrm{eq})$ were weighed and transferred to a screw-cap tube with stir bar. The tube was evacuated and backfilled three times with argon, then DMF $(0.5 \mathrm{~mL})$ was added and the screw-cap tube was sealed with a Teflon stopper and heated to $120{ }^{\circ} \mathrm{C}$ for 16 hours. At the end of the reaction, the reaction mixture was directly purified by preparative TLC as white solid (using EtOAc/MeOH $=20 / 1$ as eluent, $\mathrm{R}_{\mathrm{f}}=0.3,77 \% .33 .3 \mathrm{mg}$ ). ${ }^{1} \mathbf{H}$ NMR (400 MHz, DMSO) $\delta 9.85(\mathrm{~s}, 1 \mathrm{H}), 7.49(\mathrm{~d}, J=8.5 \mathrm{~Hz}, 2 \mathrm{H}), 7.08(\mathrm{~d}, J=8.5 \mathrm{~Hz}, 2 \mathrm{H}), 6.44$ (s, 1H), $6.37(\mathrm{~s}, 1 \mathrm{H}), 4.47(\mathrm{t}, J=5.1 \mathrm{~Hz}, 1 \mathrm{H}), 4.35-4.27(\mathrm{~m}, 1 \mathrm{H}), 4.14(\mathrm{dd}, J=8.4,3.7 \mathrm{~Hz}, 1 \mathrm{H})$, $4.00(\mathrm{dd}, J=10.6,5.0 \mathrm{~Hz}, 2 \mathrm{H}), 3.67(\mathrm{td}, J=12.2,2.4 \mathrm{~Hz}, 2 \mathrm{H}), 3.12(\mathrm{dt}, J=8.5,6.0 \mathrm{~Hz}, 1 \mathrm{H}), 2.82$ $(\mathrm{dd}, J=12.4,5.1 \mathrm{~Hz}, 1 \mathrm{H}), 2.60-2,53(\mathrm{~m}, 3 \mathrm{H}), 2.29(\mathrm{t}, J=7.4 \mathrm{~Hz}, 2 \mathrm{H}), 1.92-1.80(\mathrm{~m}, 1 \mathrm{H}), 1.77$ - 1.69 (m, 2H), $1.69-1.56(\mathrm{~m}, 3 \mathrm{H}), 1.55-1.44(\mathrm{~m}, 1 \mathrm{H}), 1.43-1.28(\mathrm{~m}, 3 \mathrm{H}) .{ }^{13} \mathbf{C}$ NMR (101 MHz, DMSO) $\delta 171.0,137.2,136.0,128.3,119.2,100.7,66.0,61.1,59.2,55.4,36.5,36.2,29.0$, 28.3, 28.1, 25.4, 25.2. HRMS (ESI) Calcd for $\left[\mathrm{C}_{22} \mathrm{H}_{32} \mathrm{~N}_{3} \mathrm{O}_{4} \mathrm{~S}\right]^{+}[\mathrm{M}+\mathrm{H}]^{+}: 434.2114$; Found: 434.2115 .

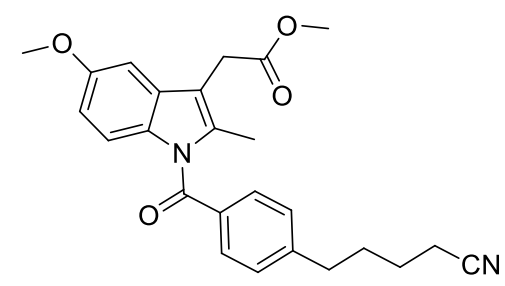

Methyl

2-(1-(4-(4-cyanobutyl)benzoyl)-5-methoxy-2-methyl-1H-indol-3-yl)acetate $\quad(b 25) . \quad \operatorname{Pd}(\mathrm{dba})_{2}$ (1.2 mg, $0.002 \mathrm{mmol}, 2 \mathrm{~mol} \%)$, ligand $\mathrm{L}_{10}(4.8 \mathrm{mg}, 0.006 \mathrm{mmol}, 6 \mathrm{~mol} \%)$, methyl 2-(1-(4-chlorbenzoyl)-5-methoxy-2-methyl-1H-indol-3-yl)acetate $(41.6 \mathrm{mg}, 0.1 \mathrm{mmol}, 1 \mathrm{eq})$ (prepared according to the literature $\left.{ }^{11}\right)$ and $\mathbf{a} 7(35.5 \mathrm{mg}, 0.12 \mathrm{mmol}, 1.2 \mathrm{eq})$ were weighed and transferred to a screw-cap tube with stir bar. The tube was evacuated and backfilled three times with argon, then $\mathrm{CH}_{3} \mathrm{CN}(0.5 \mathrm{~mL})$ was added and the screw-cap tube was sealed with a Teflon stopper and heated to $120{ }^{\circ} \mathrm{C}$ for 16 hours. At the end of the reaction, the reaction mixture was cooled to room temperature and the crude product was purified by preparative TLC as colorless oil (using petroleum ether/EtOAc $=6 / 1$ as eluent, $\left.\mathrm{R}_{\mathrm{f}}=0.2,46 \% .19 .2 \mathrm{mg}\right) . \quad{ }^{1} \mathbf{H} \mathbf{~ N M R}(\mathbf{4 0 0} \mathbf{~ M H z}$, 
$\left.\mathbf{C D C l}_{3}\right) \delta 7.69-7.62(\mathrm{~m}, 2 \mathrm{H}), 7.29(\mathrm{~d}, J=8.4 \mathrm{~Hz}, 2 \mathrm{H}), 6.96(\mathrm{~d}, J=2.5 \mathrm{~Hz}, 1 \mathrm{H}), 6.92-6.86(\mathrm{~m}$, $1 \mathrm{H}), 6.66(\mathrm{dd}, J=9.0,2.6 \mathrm{~Hz}, 1 \mathrm{H}), 3.84(\mathrm{~s}, 3 \mathrm{H}), 3.70(\mathrm{~s}, 3 \mathrm{H}), 3.67(\mathrm{~s}, 2 \mathrm{H}), 2.76(\mathrm{t}, J=7.5 \mathrm{~Hz}, 2 \mathrm{H})$, $2.50-2.28(\mathrm{~m}, 5 \mathrm{H}), 1.97-1.79(\mathrm{~m}, 2 \mathrm{H}), 1.76-1.68(\mathrm{~m}, 2 \mathrm{H}) .{ }^{13} \mathbf{C}$ NMR (101 MHz, CDCl $) \delta$ 171.5, 169.3, 155.9, 146.8, 136.1, 133.5, 131.0, 130.5, 130.1, 128.7, 119.4, 115.0, 112.0, 111.5, 101.2, 55.7, 52.1, 35.1, 30.2, 29.9, 24.9, 17.1, 13.3. HRMS (ESI) Calcd for $\left[\mathrm{C}_{25} \mathrm{H}_{26} \mathrm{~N}_{2} \mathrm{O}_{4} \mathrm{Na}\right]^{+}$ $[\mathrm{M}+\mathrm{Na}]^{+}:$441.1790; Found: 441.1789;

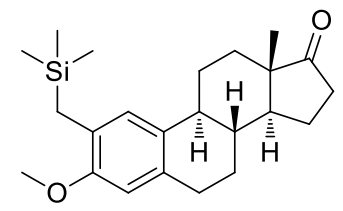

(8R,9S,13S,14S)-3-methoxy-13-methyl-2-((trimethylsilyl)methyl)-7,8,9,11,12,13,15,16-octahy dro-6H-cyclopenta[a]phenanthren-17(14H)-one (b26). $\mathrm{Pd}(\mathrm{dba})_{2}(1.2 \mathrm{mg}, 0.002 \mathrm{mmol}, 2 \mathrm{~mol} \%)$,

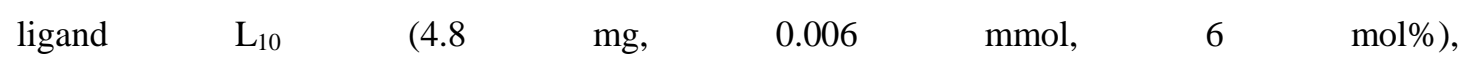
(8R,9S,13S, 14S)-2-bromo-3-methoxy-13-methyl-7,8,9,11,12,13,15,16-octahydro-6H-cyclopenta[a ]phenanthren-17(14H)-one (36.3 mg, $0.1 \mathrm{mmol}, 1 \mathrm{eq})$ (prepared according to the literature ${ }^{12}$ ) and a11 (36.0 mg, $0.12 \mathrm{mmol}, 1.2 \mathrm{eq}$ ) were weighed and transferred to a screw-cap tube with stir bar. The tube was evacuated and backfilled three times with argon, then $\mathrm{CH}_{3} \mathrm{CN}(0.5 \mathrm{~mL})$ was added and the screw-cap tube was sealed with a Teflon stopper and heated to $120^{\circ} \mathrm{C}$ for 16 hours. At the end of the reaction, the reaction mixture was cooled to room temperature and the crude product was purified by preparative TLC as white solid (using petroleum ether/EtOAc $=10 / 1$ as eluent, $R_{f}$ $=0.4,98 \% .36 .2 \mathrm{mg}) .{ }^{1} \mathbf{H}$ NMR $\left(400 \mathrm{MHz}, \mathrm{CDCl}_{3}\right) \delta 6.91(\mathrm{~s}, 1 \mathrm{H}), 6.55(\mathrm{~s}, 1 \mathrm{H}), 3.77(\mathrm{~s}, 3 \mathrm{H}), 3.02-$ $2.79(\mathrm{~m}, 2 \mathrm{H}), 2.53(\mathrm{dd}, J=18.8,8.5 \mathrm{~Hz}, 1 \mathrm{H}), 2.47-2.23(\mathrm{~m}, 2 \mathrm{H}), 2.23-1.95(\mathrm{~m}, 6 \mathrm{H}), 1.72-1.36(\mathrm{~m}$, 6H), 0.94 (s, 3H), $0.00(\mathrm{~d}, J=3.0 \mathrm{~Hz}, 9 \mathrm{H}) .{ }^{13} \mathbf{C}$ NMR $\left(101 \mathrm{MHz}, \mathrm{CDCl}_{3}\right) \delta 156.1,134.3,132.5,128.1$, 127.9, 111.7, 56.5, 51.9, 49.6, 45.5, 40.0, 37.5, 33.2, 31.1, 28.3, 27.6, 23.1, 21.7, 15.5, 0.00. HRMS (ESI) Calcd for $\left[\mathrm{C}_{23} \mathrm{H}_{35} \mathrm{O}_{2} \mathrm{Si}\right]^{+}[\mathrm{M}+\mathrm{H}]^{+}: 371.2406$; Found: 371.2392;<smiles>COc1cc2c(Nc3cccc(CCC4OCCCO4)c3)ncnc2cc1OCC1CCN(C)CC1</smiles>

$N$-(4-(2-(1,3-dioxan-2-yl)ethyl)-2-fluorophenyl)-6-methoxy-7-((1-methylpiperidin-4-yl)metho xy)quinazolin-4-amine (b27). $\mathrm{Pd}(\mathrm{dba})_{2}(1.2 \mathrm{mg}, 0.002 \mathrm{mmol}, 2 \mathrm{~mol} \%)$, ligand $\mathrm{L}_{10}(4.8 \mathrm{mg}, 0.006$ mmol, $6 \mathrm{~mol} \%$ ), Vandetanib ( $47.5 \mathrm{mg}, 0.1 \mathrm{mmol}, 1 \mathrm{eq})$ and $\mathbf{a 6}(39.5 \mathrm{mg}, 0.12 \mathrm{mmol}, 1.2 \mathrm{eq})$ were weighed and transferred to a screw-cap tube with stir bar. The tube was evacuated and backfilled three times with argon, then $\mathrm{CH}_{3} \mathrm{CN}(0.5 \mathrm{~mL})$ was added and the screw-cap tube was sealed with a Teflon stopper and heated to $120^{\circ} \mathrm{C}$ for 16 hours. At the end of the reaction, the reaction mixture was cooled to room temperature and the crude product was purified by preparative TLC as colorless oil $\left(\mathrm{CH}_{2} \mathrm{Cl}_{2} / \mathrm{MeOH}=10 / 1\right.$ as eluent, $\left.\mathrm{R}_{\mathrm{f}}=0.3,73 \% .37 .2 \mathrm{mg}\right) .{ }^{1} \mathbf{H} \mathbf{~ N M R}(400 \mathrm{MHz}$, $\left.\mathrm{CDCl}_{3}\right) \delta 8.64(\mathrm{~s}, 1 \mathrm{H}), 8.13-8.09(\mathrm{~m}, 1 \mathrm{H}), 7.28(\mathrm{~s}, 1 \mathrm{H}), 7.17(\mathrm{~s}, 1 \mathrm{H}), 7.05-7.00(\mathrm{~m}, 2 \mathrm{H}), 4.54(\mathrm{t}$, $J=5.0 \mathrm{~Hz}, 1 \mathrm{H}), 4.13(\mathrm{dd}, J=11.5,4.5 \mathrm{~Hz}, 2 \mathrm{H}), 4.01(\mathrm{~s}, 3 \mathrm{H}), 3.92(\mathrm{~s}, 2 \mathrm{H}), 3.77(\mathrm{t}, J=11.6 \mathrm{~Hz}$, $2 \mathrm{H}), 3.33(\mathrm{~d}, J=11.1 \mathrm{~Hz}, 2 \mathrm{H}), 2.81-2.67(\mathrm{~m}, 2 \mathrm{H}), 2.62(\mathrm{~s}, 3 \mathrm{H}), 2.59-2.50(\mathrm{~m}, 2 \mathrm{H}), 2.08(\mathrm{dd}, J$ $=16.8,13.1 \mathrm{~Hz}, 4 \mathrm{H}), 1.91(\mathrm{dd}, J=14.5,6.3 \mathrm{~Hz}, 2 \mathrm{H}), 1.79(\mathrm{dd}, J=16.8,10.3 \mathrm{~Hz}, 2 \mathrm{H}), 1.38(\mathrm{t}, J=$ 
$11.3 \mathrm{~Hz}, 2 \mathrm{H}) .{ }^{\mathbf{1 9}} \mathbf{F}$ NMR $\left(376 \mathrm{MHz}, \mathrm{CDCl}_{3}\right) \delta-127.56(\mathrm{~s}) .{ }^{\mathbf{1 3}} \mathbf{C} \mathbf{N M R}\left(\mathbf{1 0 1} \mathbf{~ M H z}, \mathbf{C D C l}_{\mathbf{3}}\right) \delta 156.4$, 153.9, 153.6, 149.7, 147.1, 139.3, 124.4, 124.4, 115.4, 115.2, 109.3, 108.5, 101.2, 100.0, 72.5, 66.9, 56.5, 54.7, 54.5, 44.9, 36.3, 29.5, 27.2, 25.8, 22.7, 19.6. HRMS (ESI) Calcd for $\left[\mathrm{C}_{28} \mathrm{H}_{36} \mathrm{FN}_{4} \mathrm{O}_{4}\right]^{+}[\mathrm{M}+\mathrm{H}]^{+}: 511.2721$; Found: 511.2702;<smiles></smiles>

8-(8-((tert-butyldimethylsilyl)oxy)octyl)-6-(2-fluorophenyl)-1-methyl-4H-benzo[f][1,2,4]triaz olo[4,3-a][1,4]diazepine (b28). $\mathrm{Pd}(\mathrm{dba})_{2}(1.2 \mathrm{mg}, 0.002 \mathrm{mmol}, 2 \mathrm{~mol} \%)$, ligand $\mathrm{L}_{10}(4.8 \mathrm{mg}$, $0.006 \mathrm{mmol}, 6 \mathrm{~mol} \%$ ), Flubromazolam ( $37.1 \mathrm{mg}, 0.1 \mathrm{mmol}, 1 \mathrm{eq}$ ) and $\mathbf{a 3}$ (54.8 mg, $0.12 \mathrm{mmol}$, 1.2 eq) were weighed and transferred to a screw-cap tube with stir bar. The tube was evacuated and backfilled three times with argon, then $\mathrm{CH}_{3} \mathrm{CN}(0.5 \mathrm{~mL})$ was added and the screw-cap tube was sealed with a Teflon stopper and heated to $120^{\circ} \mathrm{C}$ for 16 hours. At the end of the reaction, the reaction mixture was cooled to room temperature and the crude product was purified by preparative TLC as colorless oil (using $\mathrm{CH}_{2} \mathrm{Cl}_{2} / \mathrm{EtOAc}=5 / 1$ as eluent, $\mathrm{R}_{\mathrm{f}}=0.3,98 \% .52 .3 \mathrm{mg}$ ). ${ }^{1} \mathbf{H}$ NMR $\left(400 \mathrm{MHz}, \mathrm{CDCl}_{3}\right) \delta 7.66(\mathrm{dd}, J=7.4,6.2 \mathrm{~Hz}, 1 \mathrm{H}), 7.51-7.40(\mathrm{~m}, 2 \mathrm{H}), 7.37(\mathrm{~d}, J=8.2$ $\mathrm{Hz}, 1 \mathrm{H}), 7.30-7.20(\mathrm{~m}, 1 \mathrm{H}), 7.12(\mathrm{~s}, 1 \mathrm{H}), 7.05-6.95(\mathrm{~m}, 1 \mathrm{H}), 5.50(\mathrm{~d}, J=12.8 \mathrm{~Hz}, 1 \mathrm{H}), 4.13(\mathrm{~d}$, $J=12.8 \mathrm{~Hz}, 1 \mathrm{H}), 3.59(\mathrm{t}, J=6.6 \mathrm{~Hz}, 2 \mathrm{H}), 2.66(\mathrm{~s}, 3 \mathrm{H}), 2.61(\mathrm{t}, J=7.5 \mathrm{~Hz}, 2 \mathrm{H}), 1.65-1.43(\mathrm{~m}$, $4 \mathrm{H}), 1.27$ (s, 8H), 0.89 (s, 9H), 0.04 (s, 6H). $\left.{ }^{13} \mathrm{C} \mathrm{NMR} \mathrm{(101} \mathrm{MHz,} \mathrm{CDCl}_{3}\right) \delta$ 166.5, 161.6, 159.1, 154.9, 150.6, 142.9, $132.2(\mathrm{~d}, J=8.4 \mathrm{~Hz}), 131.6,131.2(\mathrm{~d}, J=2.2 \mathrm{~Hz}), 130.0(\mathrm{~d}, J=11.7 \mathrm{~Hz})$, $127.8(\mathrm{~d}, J=11.5 \mathrm{~Hz}), 124.4(\mathrm{~d}, J=3.5 \mathrm{~Hz}), 123.0,116.2,116.0,63.3,46.4,35.3,32.8,31.1,29.4$, 29.3, 29.0, 26.0, 25.7, 18.4, 12.3, 1.0, -5.3. HRMS (ESI) Calcd for $\left[\mathrm{C}_{31} \mathrm{H}_{44} \mathrm{FN}_{4} \mathrm{OSi}\right]^{+}[\mathrm{M}+\mathrm{H}]^{+}$: 535.3268; Found: 535.3247;<smiles>CC(c1ccc(S(N)(=O)=O)cc1)c1ccc(-c2ccccc2)c(F)c1</smiles>

(R)-4-(1-(2-fluoro-[1,1'-biphenyl]-4-yl)ethyl)benzenesulfonamide

(b29). $\mathrm{Pd}(\mathrm{dba})_{2}(1.2 \mathrm{mg}, 0.002 \mathrm{mmol}, 2 \mathrm{~mol} \%)$, ligand $\mathrm{L}_{10}(4.8 \mathrm{mg}, 0.006 \mathrm{mmol}, 6 \mathrm{~mol} \%)$, 4-bromobenzenesulfonamide (23.6 mg, $0.1 \mathrm{mmol}, 1 \mathrm{eq}$ ) and $\mathbf{a 1 8}$ (49.4 mg, $0.12 \mathrm{mmol}, 1.2 \mathrm{eq})$ were weighed and transferred to a screw-cap tube with stir bar. The tube was evacuated and backfilled three times with argon, then $\mathrm{CH}_{3} \mathrm{CN}(0.5 \mathrm{~mL})$ was added and the screw-cap tube was sealed with a Teflon stopper and heated to $120{ }^{\circ} \mathrm{C}$ for 16 hours. At the end of the reaction, the reaction mixture was cooled to room temperature and the crude product was purified by preparative TLC as thick oil (using petroleum ether/EtOAc $=4 / 1$ as eluent, $R_{f}=0.4,80 \% .28 \mathrm{mg}$ ). Racemic product was synthesized followed above procedure using a15 instead. ${ }^{1} \mathbf{H}$ NMR (400 MHz, Acetone) $\delta 7.89-7.83(\mathrm{~m}, 2 \mathrm{H}), 7.57-7.52(\mathrm{~m}, 4 \mathrm{H}), 7.50-7.42(\mathrm{~m}, 3 \mathrm{H}), 7.41-7.34(\mathrm{~m}$, 1H), $7.25-7.16(\mathrm{~m}, 2 \mathrm{H}), 6.56(\mathrm{~s}, 2 \mathrm{H}), 4.38(\mathrm{q}, J=7.2 \mathrm{~Hz}, 1 \mathrm{H}), 1.71(\mathrm{~d}, J=7.2 \mathrm{~Hz}, 3 \mathrm{H}) .{ }^{13} \mathbf{C}$ NMR (101 MHz, Acetone) $\delta 161.7,159.2,151.0,148.5(\mathrm{~d}, J=7.3 \mathrm{~Hz}), 143.1,136.4,132.7$, $131.7(\mathrm{~d}, J=3.9 \mathrm{~Hz}), 129.7,129.7(\mathrm{~d}, J=3.0 \mathrm{~Hz}), 129.3,128.8,128.5,127.6(\mathrm{~d}, J=13.5 \mathrm{~Hz})$, 127.2, 126.8, 124.7 (d, $J=3.2 \mathrm{~Hz}), 115.8(\mathrm{~d}, J=23.3 \mathrm{~Hz}), 44.8(\mathrm{~d}, J=1.2 \mathrm{~Hz}), 21.4$. HRMS (ESI) 
Calcd for $\left[\mathrm{C}_{20} \mathrm{H}_{19} \mathrm{FNO}_{2} \mathrm{~S}\right]^{+}[\mathrm{M}+\mathrm{H}]^{+}: 356.1121$; Found: 356.1110;

\begin{tabular}{ll}
\hline Column & CHIRALCEL AD-H(ADH0CE-TD152) \\
\hline Column size & $0.46 \mathrm{~cm} \mathrm{I.D.} \times 25 \mathrm{~cm} \mathrm{~L}$ \\
Injection & $2.5 \mathrm{uL}$ \\
Mobile phase & Hexane/Isopropanol = 70/30 $(\mathrm{V} / \mathrm{V})$ \\
Flow rate & $0.6 \mathrm{~mL} / \mathrm{min}$ \\
Wave length & $\mathrm{UV} 254 \mathrm{~nm}$ \\
Temperature & $25^{\circ} \mathrm{C}$ \\
\hline
\end{tabular}

$\mathrm{mV}$

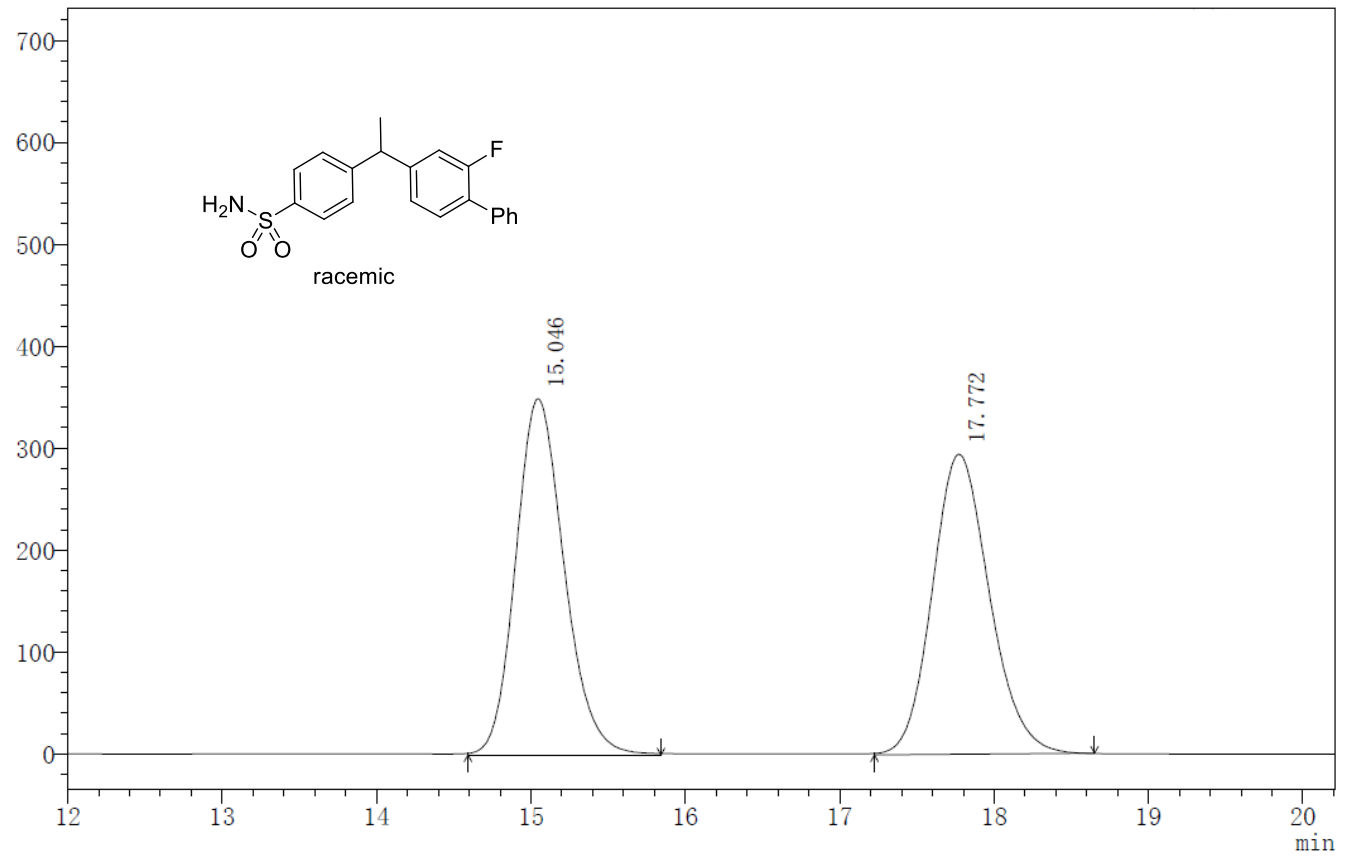

\begin{tabular}{|c|c|c|c|c|c|c|}
\hline Peak\# & Ret. Time & Area & Area\% & T.Plate\# & Tailing F. & Height \\
\hline 1 & 15.046 & 7632729 & 50.239 & 10990 & 1.174 & 349288 \\
\hline 2 & 17.772 & 7560174 & 49.761 & 11045 & 1.148 & 294299 \\
\hline
\end{tabular}




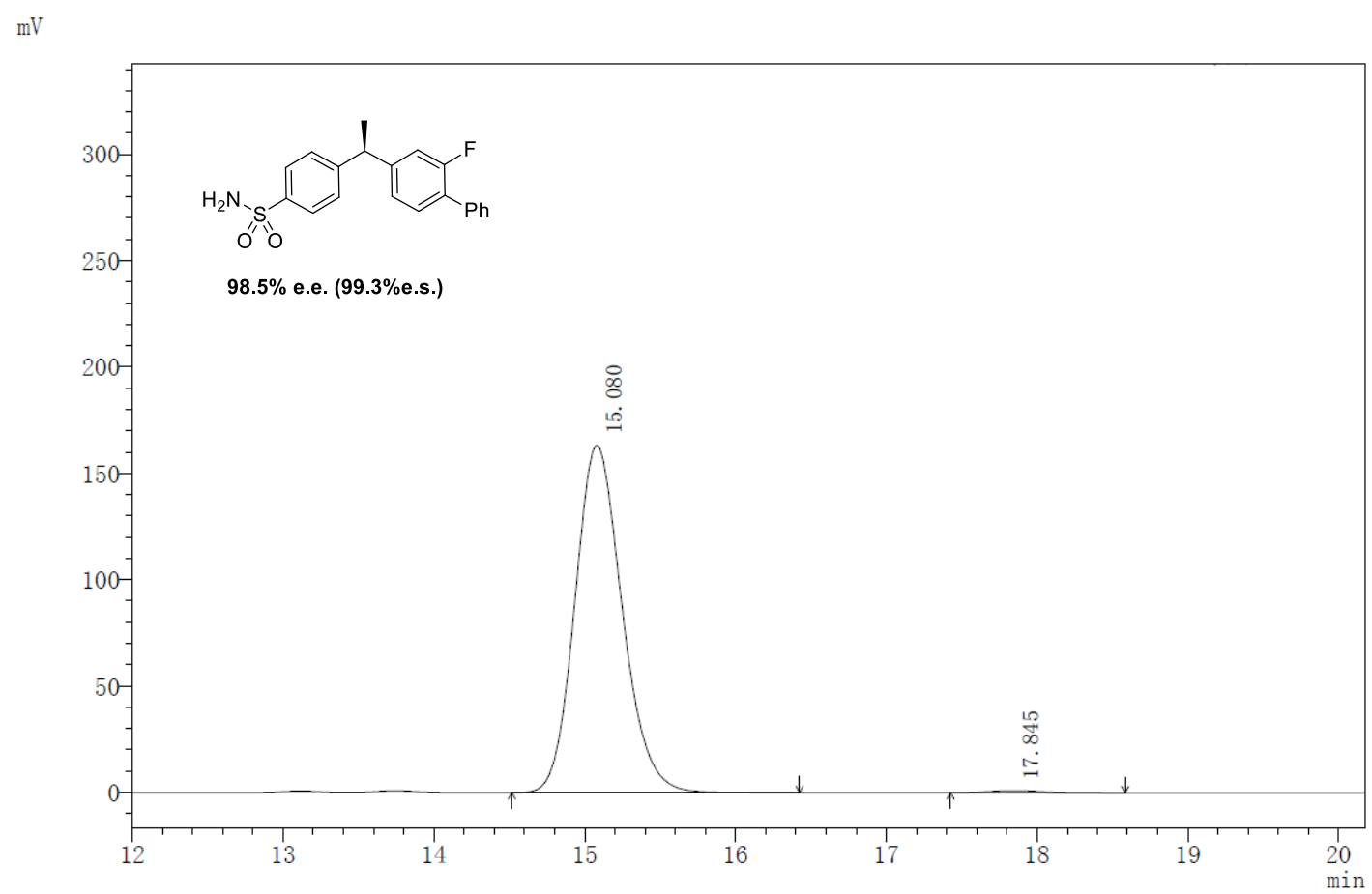

\begin{tabular}{|c|c|c|c|c|c|c|}
\hline Peak\# & Ret. Time & Area & Area\% & T.Plate\# & Tailing F. & Height \\
\hline 1 & 15.080 & 3560670 & 99.274 & 11088 & 1.160 & 163346 \\
\hline 2 & 17.845 & 26026 & 0.726 & 10814 & -- & 968 \\
\hline
\end{tabular}<smiles>c1ccc(Cc2ccc(CCC3OCCCO3)cc2)cc1</smiles>

2-(4-(2-(1,3-dioxan-2-yl)ethyl)phenyl)-4,4,5,5-tetramethyl-1,3,2-dioxaborolane

(b30).

$\mathrm{Pd}(\mathrm{dba})_{2}(1.2 \mathrm{mg}, 0.002 \mathrm{mmol}, 2 \mathrm{~mol} \%)$, ligand $\mathrm{L}_{10}(4.8 \mathrm{mg}, 0.006 \mathrm{mmol}, 6 \mathrm{~mol} \%)$, 4-bromophenylboronic acid pinacol ester ( $28.3 \mathrm{mg}, 0.1 \mathrm{mmol}, 1 \mathrm{eq}$ ) and a6 (39.5 mg, $0.12 \mathrm{mmol}$, $1.2 \mathrm{eq})$ were weighed and transferred to a screw-cap tube with stir bar. The tube was evacuated and backfilled three times with argon, then $\mathrm{CH}_{3} \mathrm{CN}(0.5 \mathrm{~mL})$ was added and the screw-cap tube was sealed with a Teflon stopper and heated to $120^{\circ} \mathrm{C}$ for 16 hours. At the end of the reaction, the reaction mixture was cooled to room temperature and the crude product was purified by preparative TLC as colorless oil (using petroleum ether/EtOAc $=20 / 1$ as eluent, $R_{\mathrm{f}}=0.3,98 \% .31$ $\mathrm{mg}) .{ }^{1} \mathbf{H}$ NMR $\left(400 \mathrm{MHz}, \mathbf{C D C l}_{3}\right) \delta 7.73(\mathrm{~d}, J=7.8 \mathrm{~Hz}, 2 \mathrm{H}), 7.21(\mathrm{~d}, J=7.7 \mathrm{~Hz}, 2 \mathrm{H}), 4.48(\mathrm{t}, J=$ $5.2 \mathrm{~Hz}, 1 \mathrm{H}), 4.11(\mathrm{dd}, J=11.1,5.3 \mathrm{~Hz}, 2 \mathrm{H}), 3.73(\mathrm{t}, J=11.6 \mathrm{~Hz}, 2 \mathrm{H}), 2.73(\mathrm{t}, J=8.1 \mathrm{~Hz}, 2 \mathrm{H})$, $2.16-2.01(\mathrm{~m}, 1 \mathrm{H}), 1.96-1.85(\mathrm{~m}, 2 \mathrm{H}), 1.33(\mathrm{~s}, 12 \mathrm{H}) .{ }^{\mathbf{1 3}} \mathbf{C} \mathbf{~ N M R}\left(\mathbf{1 0 1} \mathbf{~ M H z}, \mathbf{C D C l}_{3}\right) \delta 145.3$,

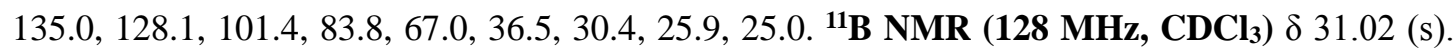
HRMS (ESI) Calcd for $\left[\mathrm{C}_{18} \mathrm{H}_{27} \mathrm{BO}_{4} \mathrm{Na}\right]^{+}[\mathrm{M}+\mathrm{Na}]^{+}: 341.1900$; Found: 341.1899.<smiles>Nc1nc(-c2ccc(CCCC(Br)c3ccccc3)cc2)cs1</smiles>

4-(4-(4,4-bis(4,4,5,5-tetramethyl-1,3,2-dioxaborolan-2-yl)butyl)phenyl)thiazol-2-amine (b31). 
$\operatorname{Pd}(\mathrm{dba})_{2}$ (1.2 mg, $\left.0.002 \mathrm{mmol}, 2 \mathrm{~mol} \%\right)$, ligand $\mathrm{L}_{10}(4.8 \mathrm{mg}, 0.006 \mathrm{mmol}, 6 \mathrm{~mol} \%)$, 2-amino-4-(4-bromophenyl)thiazole (25.5 mg, $0.1 \mathrm{mmol}, 1 \mathrm{eq}$ ) and a10 (62.8 $\mathrm{mg}, 0.12 \mathrm{mmol}, 1.2$ eq) were weighed and transferred to a screw-cap tube with stir bar. The tube was evacuated and backfilled three times with argon, then $\mathrm{CH}_{3} \mathrm{CN}(0.5 \mathrm{~mL})$ was added and the screw-cap tube was sealed with a Teflon stopper and heated to $120{ }^{\circ} \mathrm{C}$ for 16 hours. At the end of the reaction, the reaction mixture was cooled to room temperature and the crude product was purified by preparative TLC as white solid (using petroleum ether/EtOAc $=4 / 1$ as eluent, $\mathrm{R}_{\mathrm{f}}=0.3,85 \% .41$ mg). ${ }^{1} \mathbf{H}$ NMR (400 MHz, $\left.\mathbf{C D C l}_{3}\right) \delta 7.65(\mathrm{~d}, J=8.2 \mathrm{~Hz}, 2 \mathrm{H}), 7.17(\mathrm{~d}, J=8.2 \mathrm{~Hz}, 2 \mathrm{H}), 6.63(\mathrm{~s}$, $1 \mathrm{H}), 5.30(\mathrm{~s}, 2 \mathrm{H}), 2.60(\mathrm{t}, J=6.8 \mathrm{~Hz}, 2 \mathrm{H}), 1.67-1.58(\mathrm{~m}, 4 \mathrm{H}), 1.22(\mathrm{~d}, J=3.5 \mathrm{~Hz}, 24 \mathrm{H}), 0.77(\mathrm{t}$, $J=6.9 \mathrm{~Hz}, 1 \mathrm{H}) .{ }^{13} \mathbf{C}$ NMR (101 MHz, $\left.\mathbf{C D C l}_{3}\right) \delta 167.5,151.3,143.0,132.0,128.8,126.0,102.0$, 83.1, 35.9, 34.4, 25.7, 25.0, 24.7. ${ }^{11} \mathbf{B}$ NMR (128 MHz, CDCl$) ~ \delta 33.30$ (s). HRMS (ESI) Calcd for $\left[\mathrm{C}_{25} \mathrm{H}_{38} \mathrm{~B}_{2} \mathrm{~N}_{2} \mathrm{O}_{4} \mathrm{SNa}\right]^{+}[\mathrm{M}+\mathrm{Na}]^{+}:$507.2636; Found: 507.2642.<smiles>CCCCc1ccc(B(O)O)cc1</smiles>

mol\%), ligand $\mathrm{L}_{10}(14.4 \mathrm{mg}, 0.018 \mathrm{mmol}, 6 \mathrm{~mol} \%)$, 4-bromophenylboronic acid (60.0 $\mathrm{mg}, 0.3$ mmol, 1 eq) and a2 (97.2 mg, $0.36 \mathrm{mmol}, 1.2 \mathrm{eq})$ were weighed and transferred to a screw-cap tube with stir bar. The tube was evacuated and backfilled three times with argon, then $\mathrm{CH}_{3} \mathrm{CN}$ (1.5 $\mathrm{mL}$ ) was added and the screw-cap tube was sealed with a Teflon stopper and heated to $100{ }^{\circ} \mathrm{C}$ for 12 hours. At the end of the reaction, the reaction mixture was cooled to room temperature and the crude product was purified by preparative TLC as white solid (using petroleum ether/EtOAc $=5 / 1$ as eluent, $\mathrm{R}_{\mathrm{f}}=0.4,26.7 \mathrm{mg}, 50 \%$ isolated yield). ${ }^{1} \mathbf{H}$ NMR (400 MHz, $\left.\mathbf{C D C l}_{3}\right) \delta 8.14(\mathrm{~d}, J=7.8$ $\mathrm{Hz}, 2 \mathrm{H}), 7.32$ (d, $J=7.8 \mathrm{~Hz}, 2 \mathrm{H}), 2.69(\mathrm{t}, J=8.0 \mathrm{~Hz}, 2 \mathrm{H}), 1.70-1.60(\mathrm{~m}, 2 \mathrm{H}), 1.42-1.34(\mathrm{~m}$, 2H), $0.95(\mathrm{t}, J=7.3 \mathrm{~Hz}, 3 \mathrm{H}) .{ }^{13} \mathbf{C}$ NMR (101 MHz, $\left.\mathbf{C D C l}_{3}\right) \delta 148.1,135.9,128.3,36.2,33.6,22.6$, 14.1. ${ }^{11} \mathbf{B}$ NMR (128 MHz, $\left.\mathbf{C D C l}_{3}\right) \delta 29.43$ (s). HRMS (ESI) Calcd for $\left[\mathrm{C}_{10} \mathrm{H}_{15} \mathrm{BO}_{2} \mathrm{Na}^{+}\right.$ $[\mathrm{M}+\mathrm{Na}]^{+}:$201.1063; Found: 201.1063.<smiles>OB(O)c1ccc(C2CC2)cc1</smiles>

(4-cyclopropylphenyl)boronic acid (b33). $\mathrm{Pd}(\mathrm{dba})_{2}(3.6 \mathrm{mg}, 0.006 \mathrm{mmol}, 2$ mol\%), ligand $\mathrm{L}_{10}(14.4 \mathrm{mg}, 0.018 \mathrm{mmol}, 6 \mathrm{~mol} \%)$, 4-bromophenylboronic acid (60.0 $\mathrm{mg}, 0.3$ mmol, 1 eq) and a16 (91.5 mg, $0.36 \mathrm{mmol}, 1.2 \mathrm{eq})$ were weighed and transferred to a screw-cap tube with stir bar. The tube was evacuated and backfilled three times with argon, then $\mathrm{CH}_{3} \mathrm{CN}$ (1.5 $\mathrm{mL}$ ) was added and the screw-cap tube was sealed with a Teflon stopper and heated to $100{ }^{\circ} \mathrm{C}$ for 12 hours. At the end of the reaction, the reaction mixture was cooled to room temperature and then concentrated to provide the crude product. The crude product was purified by preparative TLC as white solid (using petroleum ether/EtOAc $=5 / 1$ as eluent, $\mathrm{R}_{\mathrm{f}}=0.4,31.6 \mathrm{mg}, 65 \%$ isolated yield) . ${ }^{1} \mathbf{H}$ NMR (400 MHz, CDCl$) \delta 8.10(\mathrm{~d}, J=7.8 \mathrm{~Hz}, 2 \mathrm{H}), 7.18(\mathrm{~d}, J=7.8 \mathrm{~Hz}, 2 \mathrm{H}), 2.03-1.91(\mathrm{~m}$, 1H), $1.00-1.08(\mathrm{~m}, 2 \mathrm{H}), 0.77-0.83(\mathrm{~m}, 2 \mathrm{H}) .{ }^{\mathbf{1 3}} \mathbf{C} \mathbf{N M R}\left(\mathbf{1 0 1} \mathbf{M H z}, \mathbf{C D C l}_{3}\right) \delta 149.4,135.8$, 125.2, 16.0, 10.2. ${ }^{11} \mathbf{B}$ NMR (128 MHz, $\left.\mathbf{C D C l}_{3}\right) \delta 29.48$ (s). HRMS (ESI) Calcd for $\left[\mathrm{C}_{9} \mathrm{H}_{11} \mathrm{BO}_{2} \mathrm{Na}\right]^{+}[\mathrm{M}+\mathrm{Na}]^{+}:$185.0750; Found: 185.0795 .

\section{Procedure and Characterization Data of Figure 5}


1)

8-(1-aza-5-germabicyclo[3.3.3]undecan-5-yl)octan-1-ol (a19). a3

(456.5 mg, $1.0 \mathrm{mmol}, 1.0 \mathrm{eq}$ ) was weighed and transferred to a tube with stir bar. The tube was evacuated and backfilled three times with argon, then TBAF (287 mg, $1.1 \mathrm{mmol}, 1.1 \mathrm{eq})$ dissolved in THF $(10 \mathrm{~mL})$ was added to the tube. The reaction was stirred at room temperature for 3 hours and the process could be monitored by TLC using petroleum ether/EtOAc $=5 / 1$ as eluent. At the end of the reaction, the mixture was extracted with EtOAc $(10 \mathrm{~mL}$ x 3). The combined organic layers were dried over $\mathrm{Na}_{2} \mathrm{SO}_{4}$ and concentrated in vacuo to give crude product which was purified by silica gel column chromatography as thick oil (using petroleum ether/EtOAc $=5 / 1$ as eluent, $\left.\mathrm{R}_{\mathrm{f}}=0.6,325 \mathrm{mg}, 95 \%\right) .{ }^{1} \mathrm{H}$ NMR (400 MHz, Acetone) $\delta 3.47(\mathrm{t}, J=6.6 \mathrm{~Hz}, 2 \mathrm{H}), 2.38$ $(\mathrm{t}, J=6.0 \mathrm{~Hz}, 6 \mathrm{H}), 1.56-1.38(\mathrm{~m}, 8 \mathrm{H}), 1.32-1,15(\mathrm{~m}, 10 \mathrm{H}), 0.60(\mathrm{t}, J=6.4 \mathrm{~Hz}, 6 \mathrm{H}), 0.30(\mathrm{t}, J=$ $8.0 \mathrm{~Hz}, 2 \mathrm{H}) .{ }^{13} \mathrm{C}$ NMR (101 MHz, Acetone) $\delta$ 62.5, 54.4, 35.0, 33.9, 30.4, 26.8, 26.3, 24.1, 22.3, 12.2. HRMS (ESI) Calcd for $\left[\mathrm{C}_{17} \mathrm{H}_{36}{ }^{74} \mathrm{GeNO}\right]^{+}[\mathrm{M}+\mathrm{H}]^{+}: 344.2009$; Found: 344.2009 .
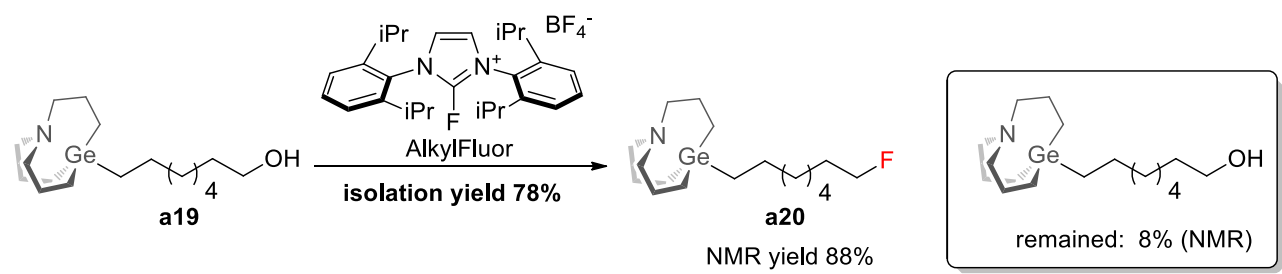

This reaction was operated according to the literature ${ }^{13}$. An oven-dried $10 \mathrm{~mL}$ tube was charged with a magnetic stir bar, potassium fluoride ( $87 \mathrm{mg}, 1.50 \mathrm{mmol}, 5.00$ equiv.) and AlkylFluor (178 $\mathrm{mg}, 0.36 \mathrm{mmol}, 1.20$ equiv.), and heated at $100{ }^{\circ} \mathrm{C}$ for 1 hour under vacuum. The mixture was cooled to room temperature, then a19 (103 mg, $0.3 \mathrm{mmol}, 1.0 \mathrm{eq})$ was weighed and added quickly. The tube was evacuated and backfilled three times with argon. Dioxane $(3 \mathrm{~mL})$ was added to the tube and the reaction was stirred at $40{ }^{\circ} \mathrm{C}$ for 17 hours. At the end of the reaction, the mixture was extracted with petroleum ether $(5 \mathrm{~mL} \times 3)$. The combined organic layers were dried over $\mathrm{Na}_{2} \mathrm{SO}_{4}$ and concentrated in vacuo to give crude product which was purified by preparative TLC as thick oil (using petroleum ether as eluent, $\mathrm{R}_{\mathrm{f}}=0.9,80 \mathrm{mg}, 78 \%$ ). Or the crude product was detected by ${ }^{1} \mathrm{H}-\mathrm{NMR}$ spectra with triphenylmethane as internal standard, we found the ${ }^{1} \mathrm{H}-\mathrm{NMR}$ yield of product $\mathbf{a 2 0}$ and reservation rate of $\mathbf{a 1 9}$ were $88 \%$ and $8 \%$ respectively. 5-(8-fluorooctyl)-1-aza-5-germabicyclo[3.3.3] undecane (a20). ${ }^{1} \mathrm{H}$ NMR (400 MHz, $\left.\mathrm{C}_{6} \mathrm{D}_{6}\right) \delta$ $4.04(\mathrm{dt}, J=47.6,6.2 \mathrm{~Hz}, 2 \mathrm{H}), 2.12(\mathrm{t}, J=6.0 \mathrm{~Hz}, 6 \mathrm{H}), 1.48-1.10(\mathrm{~m}, 18 \mathrm{H}), 0.63(\mathrm{t}, J=6.4 \mathrm{~Hz}$, $6 \mathrm{H}), 0.51(\mathrm{t}, J=8.0 \mathrm{~Hz}, 2 \mathrm{H}) .{ }^{13} \mathbf{C}$ NMR (101 MHz, $\left.\mathbf{C}_{6} \mathbf{D}_{6}\right) \delta 83.8(\mathrm{~d}, J=165.7 \mathrm{~Hz}), 53.9,34.6$, $30.8(\mathrm{~d}, J=19.5 \mathrm{~Hz}), 29.8,29.7,26.1,25.6(\mathrm{~d}, J=5.4 \mathrm{~Hz}), 23.9,22.1,12.0 .{ }^{19} \mathbf{F}$ NMR (376 MHz, C6 $\left.\mathbf{D}_{6}\right) \delta-217.6$ (relative to $\mathrm{CFCl}_{3} \delta 0.0 \mathrm{ppm}$ ).
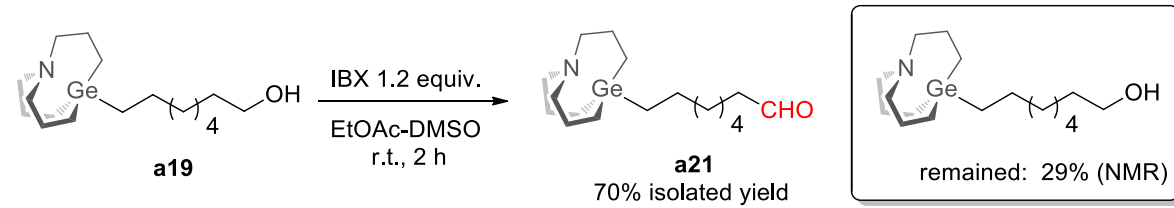

An oven-dried $10 \mathrm{~mL}$ tube was charged with a magnetic stir bar and IBX (67.2 mg, $0.24 \mathrm{mmol}$, 1.20 equiv.). The tube was evacuated and backfilled three times with argon. Then a19 (68.6 mg, $0.2 \mathrm{mmol}, 1.0 \mathrm{eq})$ was weighed and added. EtOAc $(2 \mathrm{~mL})$ and DMSO $(1 \mathrm{~mL})$ was added to the 
tube and the reaction was stirred at room temperature $\left(\sim 10^{\circ} \mathrm{C}\right)$ for 2 hours. At the end of the reaction, the mixture was extracted with EtOAc $(5 \mathrm{~mL}$ x 3$)$. The combined organic layers were dried over $\mathrm{Na}_{2} \mathrm{SO}_{4}$ and concentrated in vacuo to give crude product which was purified by preparative TLC as thick oil (using petroleum ether/EtOAc $=50 / 1$ as eluent, $\mathrm{R}_{\mathrm{f}}=0.4,48 \mathrm{mg}$, $70 \%$ ). Or the crude product was detected by ${ }^{1} \mathrm{H}-\mathrm{NMR}$ spectra with triphenylmethane as internal standard, we found the ${ }^{1} \mathrm{H}-\mathrm{NMR}$ yield of product $\mathbf{a 2 1}$ and reservation rate of $\mathbf{a 1 9}$ were $70 \%$ and 29\% respectively. 8-(1-aza-5-germabicyclo[3.3.3] undecan-5-yl)octanal (a21). ${ }^{\mathbf{1}}$ H NMR (400 MHz, C6 $\left.\mathbf{D}_{6}\right) \delta 9.32(\mathrm{t}, J=1.7 \mathrm{~Hz}, 1 \mathrm{H}), 2.25-2.12(\mathrm{~m}, 6 \mathrm{H}), 1.81(\mathrm{td}, J=7.3,1.7 \mathrm{~Hz}, 2 \mathrm{H}), 1.51-$ $1.41(\mathrm{~m}, 8 \mathrm{H}), 1.38-1.30(\mathrm{~m}, 4 \mathrm{H}), 1.27-1.20(\mathrm{~m}, 2 \mathrm{H}), 1.17-1.07(\mathrm{~m}, 2 \mathrm{H}), 0.76-0.67(\mathrm{~m}, 6 \mathrm{H})$, $0.63-0.54$ (m, 2H). ${ }^{13} \mathbf{C}$ NMR (101 MHz, C6 $\mathbf{~ D 6 ) ~} \delta 200.9,53.9,43.9,34.4,29.7,29.6,26.0,23.9$, 22.4, 22.0, 11.9. HRMS (ESI) Calcd for $\left[\mathrm{C}_{17} \mathrm{H}_{33}{ }^{74} \mathrm{GeNO}\right]^{+}[\mathrm{M}+\mathrm{H}]^{+}$: 342.1852; Found: 342.1862. NC

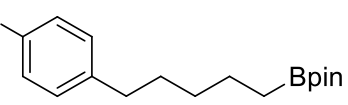

4-(5-(4,4,5,5-tetramethyl-1,3,2-dioxaborolan-2-yl)pentyl)benzonitrile (b34). $\mathrm{Pd}(\mathrm{dba})_{2}(1.2 \mathrm{mg}$, $0.002 \mathrm{mmol}, 2 \mathrm{~mol} \%$ ), ligand $\mathrm{L}_{10}(4.8 \mathrm{mg}, 0.006 \mathrm{mmol}, 6 \mathrm{~mol} \%)$, 4-bromobenzonitrile (18.2 $\mathrm{mg}$, $0.1 \mathrm{mmol}, 1 \mathrm{eq})$ and $\mathbf{a 9}(49.2 \mathrm{mg}, 0.12 \mathrm{mmol}, 1.2 \mathrm{eq})$ were weighed and transferred to a screw-cap tube with stir bar. The tube was evacuated and backfilled three times with argon, then $\mathrm{CH}_{3} \mathrm{CN}(0.5$ $\mathrm{mL}$ ) was added and the screw-cap tube was sealed with a Teflon stopper and heated to $120{ }^{\circ} \mathrm{C}$ for 16 hours. At the end of the reaction, the reaction mixture was cooled to room temperature and the crude product was purified by preparative TLC as colorless oil (using petroleum ether/EtOAc $=$ 50/1 as eluent, $\left.\mathbf{R}_{\mathrm{f}}=0.4,89 \% .26 \mathrm{mg}\right) .{ }^{1} \mathbf{H} \mathbf{N M R}\left(\mathbf{4 0 0} \mathbf{M H z}, \mathbf{C D C l}_{3}\right) \delta 7.55(\mathrm{~d}, J=7.9 \mathrm{~Hz}, 2 \mathrm{H})$, $7.27(\mathrm{~d}, J=7.9 \mathrm{~Hz}, 2 \mathrm{H}), 2.65(\mathrm{t}, J=7.6 \mathrm{~Hz}, 2 \mathrm{H}), 1.69-1.55(\mathrm{~m}, 2 \mathrm{H}), 1.48-1.38(\mathrm{~m}, 2 \mathrm{H}), 1.38-$ $1.25(\mathrm{~m}, 2 \mathrm{H}), 1.22(\mathrm{~s}, 12 \mathrm{H}), 0.77(\mathrm{t}, J=7.7 \mathrm{~Hz}, 2 \mathrm{H}) .{ }^{13} \mathbf{C}$ NMR (101 MHz, CDCl $) \delta 148.8,132.2$, 129.4, 119.4, 109.5, 83.1, 36.1, 31.9, 30.8, 24.9, 23.9. ${ }^{11} \mathbf{B}$ NMR (128 MHz, CDCl 3 ) $\delta 34.49$ (s). HRMS (ESI) Calcd for $\left[\mathrm{C}_{18} \mathrm{H}_{26} \mathrm{BNO}_{2} \mathrm{Na}\right]^{+}[\mathrm{M}+\mathrm{Na}]^{+}: 322.1954$; Found: 322.1957

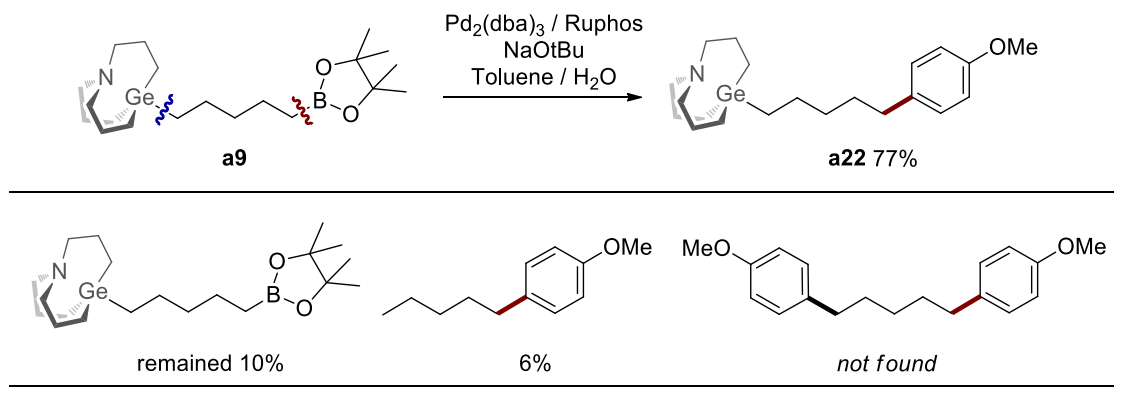

$\mathrm{Pd}_{2}(\mathrm{dba})_{3}$ (3.6 mg, $0.002 \mathrm{mmol}, 2 \mathrm{~mol} \%$ ), ligand Ruphos (3.7 mg, $0.004 \mathrm{mmol}, 4 \mathrm{~mol} \%$ ), 4-bromoanisole (18.7 mg, $0.1 \mathrm{mmol}, 1 \mathrm{eq}), \mathrm{NaOtBu}(28.8 \mathrm{mg}, 0.3 \mathrm{mmol}, 3 \mathrm{eq})$ and a9 (49.2 mg, $0.12 \mathrm{mmol}, 1.2 \mathrm{eq}$ ) were weighed and transferred to a screw-cap tube with stir bar. The tube was evacuated and backfilled three times with argon, then toluene/ $\mathrm{H}_{2} \mathrm{O}(\mathrm{v} / \mathrm{v}, 0.48 \mathrm{~mL} / 0.12 \mathrm{~mL})$ was added and the screw-cap tube was sealed with a Teflon stopper and heated to $100{ }^{\circ} \mathrm{C}$ for 24 hours. At the end of the reaction, the reaction mixture was cooled to room temperature, and extracted with EtOAc $(10 \mathrm{~mL})$. The combined organic layers were dried over $\mathrm{Na}_{2} \mathrm{SO}_{4}$ and concentrated in vacuo to give crude product. The crude product was purified by preparative TLC as colorless oil (using petroleum ether/EtOAc $=50 / 1$ as eluent, $\mathrm{R}_{\mathrm{f}}=0.6,77 \% .30 .1 \mathrm{mg}$ ). Or the crude product was detected by GC and GC-MS with triphenylmethane as internal standard, we found the GC yield of byproduct and reservation rate of $\mathbf{a 9}$ were $6 \%$ and $10 \%$ respectively. 
5-(5-(4-methoxyphenyl)pentyl)-1-aza-5-germabicyclo[3.3.3] undecane (a22). ${ }^{1} \mathrm{H}$ NMR (400 MHz, $\left.\mathbf{C}_{6} \mathbf{D}_{6}\right) \delta 7.06(\mathrm{~d}, J=8.6 \mathrm{~Hz}, 2 \mathrm{H}), 6.82(\mathrm{~d}, J=8.6 \mathrm{~Hz}, 2 \mathrm{H}), 3.35(\mathrm{~s}, 3 \mathrm{H}), 2.57(\mathrm{t}, J=8.1$ $\mathrm{Hz}, 2 \mathrm{H}), 2.20(\mathrm{t}, J=6.0 \mathrm{~Hz}, 6 \mathrm{H}), 1.68(\mathrm{dt}, J=14.9,7.6 \mathrm{~Hz}, 2 \mathrm{H}), 1.50-1.40(\mathrm{~m}, 10 \mathrm{H}), 0.69(\mathrm{t}, J=$ $6.4 \mathrm{~Hz}, 6 \mathrm{H}), 0.57(\mathrm{t}, J=8.0 \mathrm{~Hz}, 2 \mathrm{H}) .{ }^{13} \mathbf{C} \mathbf{N M R}\left(\mathbf{1 0 1} \mathbf{~ M H z}, \mathbf{C}_{6} \mathbf{D}_{6}\right) \delta 158.5,135.3,129.7,114.2$, 54.8, 53.9, 35.6, 34.2, 32.2, 26.0, 23.9, 22.0, 11.9. HRMS (ESI) Calcd for $\left[\mathrm{C}_{21} \mathrm{H}_{36}{ }^{74} \mathrm{GeNO}\right]^{+}$ $[\mathrm{M}+\mathrm{H}]^{+}:$392.2009; Found: 392.1981 .

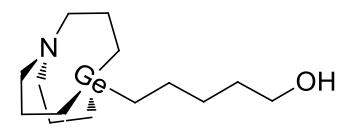

5-(1-aza-5-germabicyclo[3.3.3] undecan-5-yl)pentan-1-ol (a23). a9 (4

$\mathrm{mg}, 0.1 \mathrm{mmol}, 1 \mathrm{eq}$ ) was weighed and transferred to a tube with stir bar, then $30 \% \mathrm{H}_{2} \mathrm{O}_{2}$ aq/2M $\mathrm{NaOH}$ aq $(\mathrm{v} / \mathrm{v}, 1 / 2,0.3 \mathrm{~mL} / 0.6 \mathrm{~mL})$ was added to the tube. The reaction was stirred at room temperature for 2 minutes and the process could be monitored by TLC using petroleum ether/EtOAc $=5 / 1$ as eluent. At the end of the reaction, the mixture was extracted with EtOAc (10 $\mathrm{mL}$ ). The combined organic layers were dried over $\mathrm{Na}_{2} \mathrm{SO}_{4}$ and concentrated in vacuo to give crude product which could be purified by preparative TLC as thick oil (using petroleum ether/EtOAc $=5 / 1$ as eluent, $\left.\mathrm{R}_{\mathrm{f}}=0.6,30 \mathrm{mg}, 99 \%\right) .{ }^{1} \mathbf{H}$ NMR (400 MHz, Acetone) $\delta 3.51(\mathrm{dd}, J$ $=12.1,6.5 \mathrm{~Hz}, 2 \mathrm{H}), 2.43(\mathrm{t}, J=6.0 \mathrm{~Hz}, 6 \mathrm{H}), 1.61-1.42(\mathrm{~m}, 8 \mathrm{H}), 1.36-1.25(\mathrm{~m}, 4 \mathrm{H}), 0.65(\mathrm{t}, J=$ $6.4 \mathrm{~Hz}, 6 \mathrm{H}), 0.36(\mathrm{t}, J=8.0 \mathrm{~Hz}, 2 \mathrm{H}) .{ }^{13} \mathrm{C}$ NMR (101 MHz, Acetone) $\delta 62.7,54.4,33.8,31.2,26.2$, 24.1, 22.3, 12.2. HRMS (ESI) Calcd for $\left[\mathrm{C}_{14} \mathrm{H}_{30}{ }^{74} \mathrm{GeNO}\right]^{+}[\mathrm{M}+\mathrm{H}]^{+}: 302.1539$; Found: 302.1541 .

\section{Crystal Structure Determination of a18 and b29}

\subsection{Experimental procedure and crystal data of a18}

Single crystals of $\mathrm{C}_{23} \mathrm{H}_{30} \mathrm{FGeN}$ (a18) were grown by slow evaporation from $\mathrm{MeOH} /$ petroleum ether $(v: v, 1: 1)$ at room temperature. A suitable crystal was selected and intensity data was collected on a SuperNova, Dual, $\mathrm{Cu}$ at zero, AtlasS2 diffractometer. The crystal was kept at 290(2) K during data collection. Using Olex $2^{14}$, the structure was solved with the ShelXS-1997 ${ }^{15}$ structure solution program using Direct Methods and refined with the ShelXL ${ }^{16}$ refinement package using Least Squares minimisation. Crystal Data for $\mathrm{C}_{23} \mathrm{H}_{30} \mathrm{FGeN} \quad(M=412.07 \mathrm{~g} / \mathrm{mol})$ : orthorhombic, space group P2 $22_{1} 2_{1}$ (no. 19), $a=7.38440$ (10) $\AA, b=11.7670$ (3) $\AA, c=$ 24.0742(5) $\AA, V=\quad 2091.86(7) \AA^{3}, Z=4, T=290(2) \mathrm{K}, \quad \mu(\mathrm{CuK \alpha})=2.094$ $\mathrm{mm}^{-1}$, Dcalc $=1.308 \mathrm{~g} / \mathrm{cm}^{3}, 7186$ reflections measured $\left(7.344^{\circ} \leq 2 \Theta \leq 142.85^{\circ}\right), 3923$ unique $\left(R_{\text {int }}=0.0306, \mathrm{R}_{\text {sigma }}=0.0390\right)$ which were used in all calculations. The final $R_{1}$ was $0.0398(\mathrm{I}>2 \sigma(\mathrm{I}))$ and $w R_{2}$ was 0.1015 (all data). 


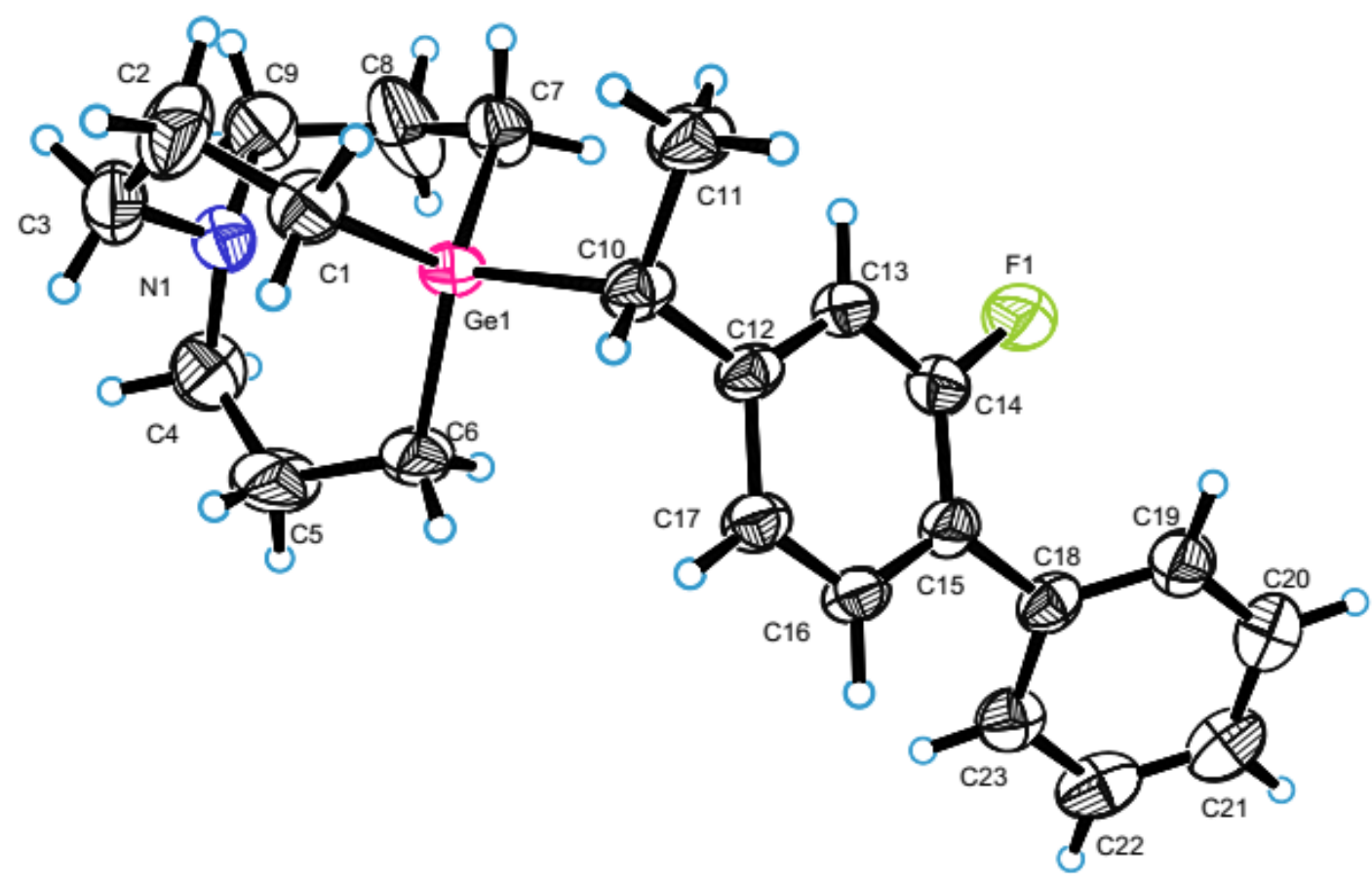

Figure S1. X-ray structure of compound a18.

Table S1. Crystal data and structure refinement for $\mathrm{C}_{23} \mathrm{H}_{30} \mathrm{FGeN}$ (a18).

$\begin{array}{cc}\text { Identification code } & \mathrm{C}_{23} \mathrm{H}_{30} \mathrm{FGeN} \\ \text { Empirical formula } & \mathrm{C}_{23} \mathrm{H}_{30} \mathrm{FGeN} \\ \text { Formula weight } & 412.07 \\ \text { Temperature/K } & 290(2) \\ \text { Crystal system } & \text { orthorhombic } \\ \text { Space group } & \mathrm{P} 2{ }_{1} 2{ }_{1}{ }_{1} \\ \mathrm{a} / \AA & 7.38440(10) \\ \mathrm{b} / \AA & 11.7670(3) \\ \mathrm{c} / \AA & 24.0742(5) \\ \alpha /{ }^{\circ} & 90 \\ \beta /{ }^{\circ} & 90 \\ \gamma^{\circ} & 90 \\ { }^{\circ} & 2091.86(7) \\ \mathrm{Z} & 4 \\ \rho_{\text {calcg }} / \mathrm{cm}^{3} & 1.308 \\ \mu / \mathrm{mm}^{-1} & 2.094 \\ \mathrm{~F}(000) & 864.0 \\ \text { Crystal size/mm } & \\ \text { Radiation } & 0.220 \times 0.210 \times 0.170 \\ 2 \Theta \text { range for data collection } /{ }^{\circ} & \mathrm{CuK} \alpha(\lambda=1.54184) \\ & 7.344 \text { to } 142.85\end{array}$




$\begin{array}{cc}\text { Index ranges } & -5 \leq \mathrm{h} \leq 8,-13 \leq \mathrm{k} \leq 14,-26 \leq 1 \leq 29 \\ \text { Reflections collected } & 7186 \\ \text { Independent reflections } & 3923\left[\mathrm{R}_{\text {int }}=0.0306, \mathrm{R}_{\text {sigma }}=0.0390\right] \\ \text { Data/restraints/parameters } & 3923 / 0 / 236 \\ \text { Goodness-of-fit on } \mathrm{F}^{2} & 1.053 \\ \text { Final R indexes [I }>=2 \sigma(\mathrm{I})] & \mathrm{R}_{1}=0.0398, \mathrm{wR}_{2}=0.0976 \\ \text { Final R indexes [all data] } & \mathrm{R}_{1}=0.0444, \mathrm{wR}_{2}=0.1015 \\ \text { Largest diff. peak/hole / e } \AA^{-3} & 0.49 /-0.39 \\ \text { Flack parameter } & -0.023(19)\end{array}$

Table S2. Fractional Atomic Coordinates $\left(\times 10^{4}\right)$ and Equivalent Isotropic Displacement Parameters $\left(\AA^{2} \times \mathbf{1 0}^{3}\right)$ for $\mathbf{C}_{23} \mathbf{H}_{30}$ FGeN (a18). $U_{\text {eq }}$ is defined as $1 / 3$ of of the trace of the orthogonalised $\mathrm{U}_{\mathrm{IJ}}$ tensor.

$\begin{array}{ccccc}\text { Atom } & x & y & z & \mathrm{U}(\mathrm{eq}) \\ \mathrm{Ge} 1 & 7568.1(7) & 476.6(4) & 1566.0(2) & 48.14(16) \\ \text { F1 } & 7443(6) & -4498(3) & 1296.8(16) & 93.1(10) \\ \text { C6 } & 10225(6) & 427(6) & 1544(3) & 74.6(16) \\ \text { C12 } & 7734(7) & -1570(5) & 852.0(18) & 55.6(12) \\ \text { C10 } & 6743(7) & -472(5) & 906(2) & 60.0(12) \\ \text { C17 } & 9362(7) & -1631(5) & 552(2) & 60.0(13) \\ \text { C13 } & 7150(7) & -2571(5) & 1100(2) & 64.6(15) \\ \text { C23 } & 12585(10) & -4756(5) & 693(2) & 71.2(14) \\ \text { C14 } & 8099(7) & -3556(5) & 1032(2) & 63.6(14) \\ \text { C7 } & 6477(9) & -280(5) & 2216(2) & 71.5(16) \\ \text { C16 } & 10288(7) & -2640(5) & 491(2) & 61.6(14) \\ \text { C15 } & 9699(7) & -3651(5) & 732(2) & 58.5(13) \\ \text { C21 } & 12642(13) & -6754(6) & 511(3) & 88(2) \\ \text { C1 } & 6550(8) & 1973(5) & 1376(3) & 70.8(16) \\ \text { C18 } & 10693(7) & -4739(5) & 662(2) & 60.1(14) \\ \text { C9 } & 7575(15) & 1249(6) & 2857(2) & 94(2) \\ \text { C8 } & 7262(18) & 46(7) & 2762(3) & 125(4) \\ \text { C11 } & 4674(7) & -599(7) & 910(3) & 81.8(19) \\ \text { C19 } & 9840(9) & -5754(6) & 550(3) & 73.1(16) \\ \text { C20 } & 10775(12) & -6752(6) & 479(3) & 86(2) \\ \text { C22 } & 13521(10) & -5755(8) & 621(3) & 87(2) \\ \text { N1 } & 8522(6) & 1769(4) & 2389(2) & 64.4(12) \\ \text { C3 } & 7849(10) & 2876(5) & 2224(3) & 89(2) \\ \text { C4 } & 10472(9) & 1660(7) & 2396(3) & 92(2) \\ \text { C2 } & 6282(12) & 2785(6) & 1843(4) & 105(3)\end{array}$



C5 $11170(8)$
$1335(8)$
$1850(4)$
$112(3)$

Table S3. Anisotropic Displacement Parameters $\left(\AA^{2} \times 1^{3}\right)$ for $\mathbf{C}_{23} \mathrm{H}_{30} \mathrm{FGeN}$ (a18).

The Anisotropic displacement factor exponent takes the form: $-2 \pi^{2}\left[h^{2} a * 2 U_{11}+2 h k a * b * U_{12}+\ldots\right]$.

$\begin{array}{ccccccc}\text { Atom } & \mathrm{U}_{11} & \mathrm{U}_{22} & \mathrm{U}_{33} & \mathrm{U}_{23} & \mathrm{U}_{13} & \mathrm{U}_{12} \\ \mathrm{G} 1 & 39.9(2) & 54.9(3) & 49.6(3) & 2.1(2) & 1.1(3) & 4.7(3) \\ \mathrm{F} 1 & 94(2) & 76(2) & 109(3) & -1.1(19) & 36(2) & -12(3) \\ \mathrm{C} 6 & 39(2) & 93(4) & 91(4) & -15(4) & -1(3) & 6(3) \\ \mathrm{C} 12 & 45(3) & 77(3) & 45(2) & -14(2) & -2(2) & 7(3) \\ \mathrm{C} 10 & 52(2) & 80(4) & 48(3) & -7(3) & -1.0(19) & 6(3) \\ \mathrm{C} 17 & 55(3) & 72(4) & 53(3) & -6(3) & 7(2) & 1(3) \\ \mathrm{C} 13 & 52(3) & 77(4) & 65(3) & -17(3) & 11(2) & -5(3) \\ \mathrm{C} 23 & 66(3) & 92(4) & 56(3) & -5(2) & -5(3) & 4(4) \\ \mathrm{C} 14 & 61(3) & 68(4) & 62(3) & -6(3) & 9(2) & -10(3) \\ \mathrm{C} 7 & 87(4) & 71(4) & 56(3) & 7(3) & 6(3) & -17(3) \\ \mathrm{C} 16 & 54(3) & 75(4) & 56(3) & -12(3) & 12(2) & 2(3) \\ \mathrm{C} 15 & 55(3) & 68(3) & 53(3) & -13(3) & 0(2) & -1(3) \\ \mathrm{C} 21 & 103(5) & 90(5) & 72(4) & 6(3) & -1(4) & 37(6) \\ \mathrm{C} 1 & 61(3) & 67(4) & 84(4) & 12(3) & -9(3) & 15(3) \\ \mathrm{C} 18 & 62(3) & 72(4) & 47(3) & -7(2) & -2(2) & 10(3) \\ \mathrm{C} 9 & 114(5) & 111(5) & 57(3) & -17(3) & 11(5) & -25(6) \\ \mathrm{C} 8 & 191(10) & 127(6) & 57(3) & 13(4) & 2(6) & -87(7) \\ \mathrm{C} 11 & 50(3) & 114(5) & 82(4) & -24(4) & -11(3) & 15(3) \\ \mathrm{C} 19 & 71(4) & 76(4) & 72(4) & -8(3) & -1(3) & 1(3) \\ \mathrm{C} 20 & 108(6) & 74(4) & 77(4) & -7(3) & -5(4) & 8(4) \\ \mathrm{C} 22 & 74(4) & 120(7) & 67(4) & 5(4) & -6(3) & 36(4) \\ \mathrm{N} 1 & 65(3) & 62(3) & 67(3) & -4(2) & 0(2) & -6(2) \\ \mathrm{C} 3 & 85(5) & 63(4) & 119(5) & -20(3) & -9(4) & -4(3) \\ \mathrm{C} 4 & 73(4) & 108(6) & 94(5) & -22(4) & -26(4) & -3(4) \\ \mathrm{C} 2 & 109(6) & 69(5) & 138(7) & -19(5) & -28(5) & 34(4) \\ \mathrm{C} 5 & 43(3) & 162(8) & 132(7) & -46(6) & -2(4) & -13(4) \\ & & & & & & \end{array}$

Table S4. Bond Lengths for $\mathrm{C}_{23} \mathrm{H}_{30} \mathrm{FGeN}$ (a18).

Atom Atom Length $/ \AA$ Atom Atom Length $/ \AA$

Ge1 C6 $1.964(5) \quad$ C7 $\quad$ C8 $\quad 1.487(9)$

Ge1 C1 $1.969(5) \quad \mathrm{C} 16 \quad \mathrm{C} 15 \quad 1.394(8)$ 


$\begin{array}{cccccc}\text { Ge1 } & \mathrm{C} 7 & 1.972(5) & \mathrm{C} 15 & \mathrm{C} 18 & 1.486(8) \\ \mathrm{Ge} 1 & \mathrm{C} 10 & 2.035(5) & \mathrm{C} 21 & \mathrm{C} 22 & 1.368(11) \\ \mathrm{F} 1 & \mathrm{C} 14 & 1.368(6) & \mathrm{C} 21 & \mathrm{C} 20 & 1.381(12) \\ \mathrm{C} 6 & \mathrm{C} 5 & 1.473(10) & \mathrm{C} 1 & \mathrm{C} 2 & 1.489(10) \\ \mathrm{C} 12 & \mathrm{C} 13 & 1.389(8) & \mathrm{C} 18 & \mathrm{C} 19 & 1.376(8) \\ \mathrm{C} 12 & \mathrm{C} 17 & 1.404(7) & \mathrm{C} 9 & \mathrm{C} 8 & 1.453(10) \\ \mathrm{C} 12 & \mathrm{C} 10 & 1.491(8) & \mathrm{C} 9 & \mathrm{~N} 1 & 1.460(8) \\ \mathrm{C} 10 & \mathrm{C} 11 & 1.535(7) & \mathrm{C} 19 & \mathrm{C} 20 & 1.373(9) \\ \mathrm{C} 17 & \mathrm{C} 16 & 1.379(8) & \mathrm{N} 1 & \mathrm{C} 4 & 1.445(8) \\ \mathrm{C} 13 & \mathrm{C} 14 & 1.365(8) & \mathrm{N} 1 & \mathrm{C} 3 & 1.449(8) \\ \mathrm{C} 23 & \mathrm{C} 22 & 1.376(9) & \mathrm{C} 3 & \mathrm{C} 2 & 1.480(10) \\ \mathrm{C} 23 & \mathrm{C} 18 & 1.399(9) & \mathrm{C} 4 & \mathrm{C} 5 & 1.463(10) \\ \mathrm{C} 14 & \mathrm{C} 15 & 1.389(7) & & & \end{array}$

Table S5. Bond Angles for $\mathrm{C}_{23} \mathrm{H}_{30} \mathrm{FGeN}$ (a18).

\begin{tabular}{|c|c|c|c|c|c|c|c|}
\hline \multicolumn{3}{|c|}{ Atom Atom Atom } & \multirow{2}{*}{$\begin{array}{l}\text { Angle/ }{ }^{\circ} \\
113.7(3)\end{array}$} & \multicolumn{3}{|c|}{ Atom Atom Atom } & \multirow{2}{*}{$\begin{array}{l}\text { Angle }^{\circ} \\
114.4(5)\end{array}$} \\
\hline C6 & Ge1 & $\mathrm{C} 1$ & & $\mathrm{C} 14$ & $\mathrm{C} 15$ & C16 & \\
\hline C6 & Ge1 & $\mathrm{C} 7$ & $114.6(3)$ & $\mathrm{C} 14$ & $\mathrm{C} 15$ & C18 & $123.3(6)$ \\
\hline $\mathrm{C} 1$ & Ge1 & $\mathrm{C} 7$ & $115.6(3)$ & $\mathrm{C} 16$ & $\mathrm{C} 15$ & C18 & $122.3(5)$ \\
\hline C6 & Ge1 & $\mathrm{C} 10$ & $105.2(2)$ & $\mathrm{C} 22$ & $\mathrm{C} 21$ & $\mathrm{C} 20$ & $119.0(7)$ \\
\hline $\mathrm{C} 1$ & Ge1 & $\mathrm{C} 10$ & $101.2(2)$ & $\mathrm{C} 2$ & $\mathrm{C} 1$ & Ge1 & $116.7(5)$ \\
\hline $\mathrm{C} 7$ & Ge1 & $\mathrm{C} 10$ & $104.5(2)$ & $\mathrm{C} 19$ & $\mathrm{C} 18$ & $\mathrm{C} 23$ & $117.1(6)$ \\
\hline $\mathrm{C} 5$ & C6 & $\mathrm{Ge} 1$ & $116.0(4)$ & C19 & $\mathrm{C} 18$ & $\mathrm{C} 15$ & $122.9(5)$ \\
\hline $\mathrm{C} 13$ & $\mathrm{C} 12$ & $\mathrm{C} 17$ & $116.4(5)$ & $\mathrm{C} 23$ & $\mathrm{C} 18$ & $\mathrm{C} 15$ & $119.9(5)$ \\
\hline $\mathrm{C} 13$ & $\mathrm{C} 12$ & $\mathrm{C} 10$ & $123.0(5)$ & $\mathrm{C} 8$ & C9 & N1 & $111.4(6)$ \\
\hline $\mathrm{C} 17$ & $\mathrm{C} 12$ & $\mathrm{C} 10$ & $120.6(5)$ & C9 & $\mathrm{C} 8$ & $\mathrm{C} 7$ & $116.8(7)$ \\
\hline $\mathrm{C} 12$ & $\mathrm{C} 10$ & $\mathrm{C} 11$ & $113.9(6)$ & $\mathrm{C} 20$ & C19 & C18 & $122.4(6)$ \\
\hline $\mathrm{C} 12$ & $\mathrm{C} 10$ & $\mathrm{Ge} 1$ & $113.3(3)$ & C19 & $\mathrm{C} 20$ & $\mathrm{C} 21$ & $119.7(8)$ \\
\hline $\mathrm{C} 11$ & $\mathrm{C} 10$ & Ge1 & $110.3(4)$ & $\mathrm{C} 21$ & $\mathrm{C} 22$ & $\mathrm{C} 23$ & $121.3(6)$ \\
\hline $\mathrm{C} 16$ & $\mathrm{C} 17$ & $\mathrm{C} 12$ & $121.6(5)$ & $\mathrm{C} 4$ & $\mathrm{~N} 1$ & $\mathrm{C} 3$ & $115.1(6)$ \\
\hline $\mathrm{C} 14$ & $\mathrm{C} 13$ & $\mathrm{C} 12$ & $120.6(5)$ & $\mathrm{C} 4$ & $\mathrm{~N} 1$ & $\mathrm{C} 9$ & $115.6(7)$ \\
\hline $\mathrm{C} 22$ & $\mathrm{C} 23$ & C18 & $120.5(6)$ & $\mathrm{C} 3$ & N1 & $\mathrm{C} 9$ & $115.1(6)$ \\
\hline C13 & C14 & $\mathrm{F} 1$ & $116.8(5)$ & N1 & $\mathrm{C} 3$ & $\mathrm{C} 2$ & $111.9(5)$ \\
\hline $\mathrm{C} 13$ & C14 & $\mathrm{C} 15$ & $124.6(6)$ & N1 & $\mathrm{C} 4$ & $\mathrm{C} 5$ & $111.4(6)$ \\
\hline $\mathrm{F} 1$ & C14 & C15 & $118.6(5)$ & $\mathrm{C} 3$ & $\mathrm{C} 2$ & $\mathrm{C} 1$ & $114.2(6)$ \\
\hline $\mathrm{C} 8$ & $\mathrm{C} 7$ & Ge1 & $115.2(5)$ & $\mathrm{C} 4$ & $\mathrm{C} 5$ & C6 & $118.2(7)$ \\
\hline $\mathrm{C} 17$ & $\mathrm{C} 16$ & C15 & $122.4(5)$ & & & & \\
\hline
\end{tabular}


Table S6. Torsion Angles for $\mathrm{C}_{23} \mathrm{H}_{30} \mathrm{FGeN}$ (a18).

\begin{tabular}{|c|c|c|c|}
\hline A $\quad$ B $\quad$ C & ${ }^{\circ}$ & A B & \\
\hline $\mathrm{C} 13 \mathrm{C} 12 \mathrm{C} 10 \mathrm{C} 11$ & $-36.6(7)$ & C14C15C18 & $-139.2(6)$ \\
\hline $17 \mathrm{C} 12 \mathrm{C} 10 \mathrm{C} 11$ & $145.0(5)$ & C16C15C18C23 & $42.1(7)$ \\
\hline $13 \mathrm{C} 12 \mathrm{C} 10 \mathrm{Ge} 1$ & $90.5(5)$ & $\begin{array}{llll}\text { N1 } & \text { C9 } & \text { C8 } & \text { C7 }\end{array}$ & $-48.4(15)$ \\
\hline $0 \mathrm{Ge} 1$ & -87 & Ge1C7 C8 C9 & 14) \\
\hline 6 & 2.4 & C23 C18 C19C20 & 9) \\
\hline 6 & -17 & $\mathrm{C} 15 \mathrm{C} 1$ & 17 \\
\hline $\mathrm{C} 14$ & $-2.2(8)$ & $\mathrm{C} 18 \mathrm{C} 19 \mathrm{C}$ & \\
\hline $10 \mathrm{C} 12$ & 179.3 & $\mathrm{C} 22 \mathrm{C} 21 \mathrm{C} 20 \mathrm{C}$ & 1) \\
\hline $4 \mathrm{~F} 1$ & 179.1 & C20C21 C22 C23 & $-0.6(10)$ \\
\hline $12 \mathrm{C} 13 \mathrm{C} 14 \mathrm{C} 15$ & $1.5(9)$ & C18C23 C22 C21 & $0.6(9)$ \\
\hline $12 \mathrm{C} 17 \mathrm{C} 16 \mathrm{C} 15$ & $-1.7(8)$ & $\begin{array}{llll}\mathrm{C} 8 & \mathrm{C} 9 & \mathrm{~N} 1 & \mathrm{C} 4\end{array}$ & $-84.3(11)$ \\
\hline C13C14C15C16 & $-0.6(8)$ & $\begin{array}{llll}\mathrm{C} 8 & \mathrm{C} 9 & \mathrm{~N} 1 & \mathrm{C} 3\end{array}$ & $137.7(9)$ \\
\hline F1 C14C15C16 & $-178.2(5)$ & $\mathrm{C} 4 \mathrm{~N} 1 \mathrm{C} 3 \mathrm{C} 2$ & $137.7(7)$ \\
\hline C13C14C15C18 & $-179.5(5)$ & C9 N1 C3 C2 & $-84.1(8)$ \\
\hline F1 C14C15C18 & $2.9(8)$ & C3 N1 C4 C5 & $-86.9(8)$ \\
\hline C17C16C15 C14 & $0.7(8)$ & C9 N1 C4 C5 & $135.1(7)$ \\
\hline C17C16C15C18 & $179.6(5)$ & $\mathrm{N} 1 \mathrm{C} 3 \mathrm{C} 2 \mathrm{C} 1$ & $-47.9(10)$ \\
\hline C22C23 C18C19 & $-0.8(8)$ & $\mathrm{Ge} 1 \mathrm{C} 1 \mathrm{C} 2 \mathrm{C} 3$ & $46.4(9)$ \\
\hline C22C23C18C15 & $-179.0(5)$ & $\mathrm{N} 1 \mathrm{C} 4 \mathrm{C} 5 \mathrm{C} 6$ & $-44.6(11)$ \\
\hline $\mathrm{C} 14 \mathrm{C} 15$ & $42.7(8)$ & Ge1C6 C5 C4 & $41.8(11)$ \\
\hline C16C15C18C19 & -136.1( & & \\
\hline
\end{tabular}

Table S7. Hydrogen Atom Coordinates $\left(\AA \times 10^{4}\right)$ and Isotropic Displacement Parameters $\left(\AA^{2} \times \mathbf{1 0}^{3}\right)$ for $\mathrm{C}_{23} \mathrm{H}_{30} \mathrm{FGeN}(\mathbf{a 1 8})$.

$\begin{array}{ccccc}\text { Atom } & x & y & z & \mathrm{U}(\mathrm{eq}) \\ \text { H6A } & 10617 & -299 & 1692 & 89 \\ \text { H6B } & 10605 & 459 & 1158 & 89 \\ \text { H10 } & 7039 & -29 & 573 & 72 \\ \text { H17 } & 9826 & -974 & 391 & 72 \\ \text { H13 } & 6102 & -2569 & 1314 & 78 \\ \text { H23 } & 13213 & -4086 & 764 & 85 \\ \text { H7A } & 5192 & -110 & 2221 & 86 \\ \text { H7B } & 6606 & -1095 & 2171 & 86 \\ \text { H16 } & 11345 & -2647 & 280 & 74 \\ \text { H21 } & 13291 & -7423 & 460 & 106 \\ \text { H1A } & 7342 & 2329 & 1106 & 85 \\ \text { H1B } & 5388 & 1854 & 1197 & 85\end{array}$




$\begin{array}{ccccc}\text { H9A } & 8289 & 1347 & 3192 & 113 \\ \text { H9B } & 6424 & 1630 & 2912 & 113 \\ \text { H8A } & 6458 & -229 & 3052 & 150 \\ \text { H8B } & 8407 & -348 & 2805 & 150 \\ \text { H11A } & 4309 & -1006 & 1237 & 123 \\ \text { H11B } & 4296 & -1011 & 586 & 123 \\ \text { H11C } & 4122 & 140 & 910 & 123 \\ \text { H19 } & 8584 & -5764 & 521 & 88 \\ \text { H20 } & 10153 & -7425 & 409 & 104 \\ \text { H22 } & 14778 & -5752 & 646 & 104 \\ \text { H3A } & 8812 & 3294 & 2041 & 106 \\ \text { H3B } & 7493 & 3298 & 2552 & 106 \\ \text { H4A } & 10818 & 1091 & 2667 & 110 \\ \text { H4B } & 11007 & 2378 & 2507 & 110 \\ \text { H2A } & 6028 & 3532 & 1691 & 126 \\ \text { H2B } & 5230 & 2550 & 2055 & 126 \\ \text { H5A } & 12421 & 1104 & 1897 & 135 \\ \text { H5B } & 11172 & 2009 & 1618 & 135\end{array}$

\subsection{Experimental procedure and crystal data of b29}

Single crystals of $\mathrm{C}_{20} \mathrm{H}_{18} \mathrm{FNO}_{2} \mathrm{~S}$ (b29) were grown by slow evaporation from benzotrifluoride at room temperature.. A suitable crystal was selected and intensity data was collected on a SuperNova, Dual, $\mathrm{Cu}$ at zero, AtlasS2 diffractometer. The crystal was kept at 290(2) K during data collection. Using Olex $2^{14}$, the structure was solved with the ShelXS-1997 ${ }^{15}$ structure solution program using Direct Methods and refined with the ShelXL ${ }^{16}$ refinement package using Least Squares minimisation. Crystal Data for $\mathrm{C}_{20} \mathrm{H}_{18} \mathrm{FNO}_{2} \mathrm{~S}(M=355.41 \mathrm{~g} / \mathrm{mol})$ : monoclinic, space group $\mathrm{P} 2{ }_{1}$ (no. 4), $a=6.20290(10) \AA, b=8.50400(10) \AA, c=16.5123(2) \AA, \beta=97.2830(10)^{\circ}, V=$ 863.99(2) $\AA^{3}, Z=2, T=290(2) \mathrm{K}, \mu(\mathrm{CuK \alpha})=1.865 \mathrm{~mm}^{-1}$, Dcalc $=1.366 \mathrm{~g} / \mathrm{cm}^{3}, 6966$ reflections measured $\left(10.804^{\circ} \leq 2 \Theta \leq 142.656^{\circ}\right), 3056$ unique $\left(R_{\text {int }}=0.0279, \mathrm{R}_{\text {sigma }}=\right.$ $0.0294)$ which were used in all calculations. The final $R_{1}$ was 0.0550 (I $>2 \sigma(\mathrm{I})$ ) and $w R_{2}$ was 0.1580 (all data). 


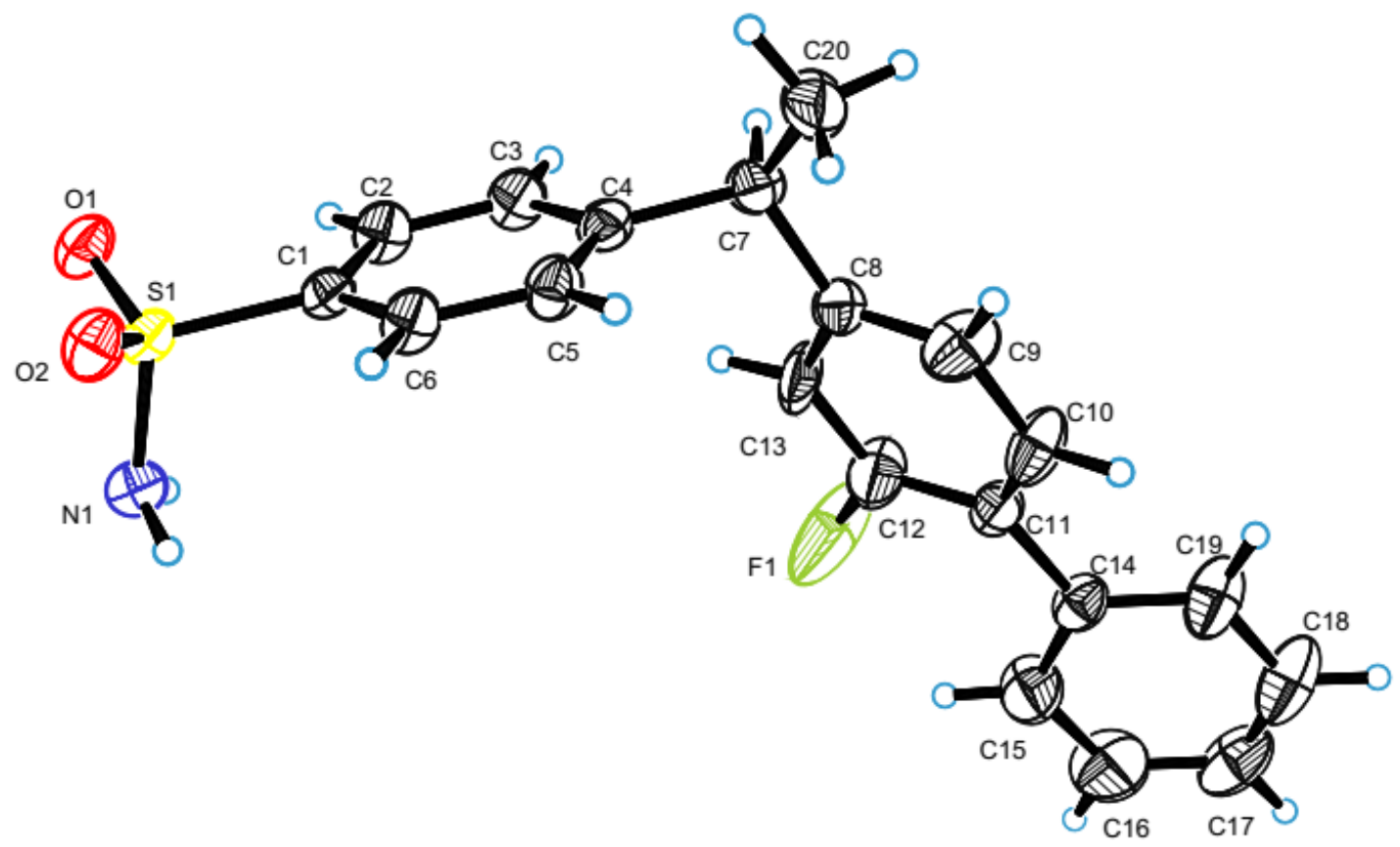

Figure S2. X-ray structure of compound b29.

Table S8. Crystal data and structure refinement for $\mathrm{C}_{20} \mathrm{H}_{18} \mathrm{FNO}_{2} \mathrm{~S}$ (b29).

Identification code

Empirical formula

Formula weight

Temperature/K

Crystal system

Space group

$\mathrm{a} / \AA$

$\mathrm{b} / \AA$

$\mathrm{c} / \AA$

$\alpha /^{\circ}$

$\beta /{ }^{\circ}$

$\gamma /{ }^{\circ}$

Volume $/ \AA^{3}$

$\mathrm{Z}$

$\rho_{\text {calc }} / \mathrm{cm}^{3}$

$\mu / \mathrm{mm}^{-1}$

$\mathrm{F}(000)$

Crystal size $/ \mathrm{mm}^{3}$

Radiation

$2 \Theta$ range for data collection/ ${ }^{\circ}$

Index ranges

Reflections collected
$\mathrm{C}_{20} \mathrm{H}_{18} \mathrm{FNO}_{2} \mathrm{~S}$

$\mathrm{C}_{20} \mathrm{H}_{18} \mathrm{FNO}_{2} \mathrm{~S}$

355.41

290(2)

monoclinic

$\mathrm{P} 21$

6.20290(10)

$8.50400(10)$

$16.5123(2)$

90

97.2830(10)

90

$863.99(2)$

2

1.366

1.865

372.0

$0.220 \times 0.220 \times 0.150$

$\mathrm{CuK} \alpha(\lambda=1.54184)$

10.804 to 142.656

$-7 \leq \mathrm{h} \leq 7,-10 \leq \mathrm{k} \leq 9,-20 \leq 1 \leq 19$

6966 
Independent reflections

Data/restraints/parameters

Goodness-of-fit on $\mathrm{F}^{2}$

Final $\mathrm{R}$ indexes $[\mathrm{I}>=2 \sigma(\mathrm{I})]$

Final $\mathrm{R}$ indexes [all data]

Largest diff. peak/hole / e $\AA^{-3}$

Flack parameter

$$
\begin{gathered}
3056\left[\mathrm{R}_{\text {int }}=0.0279, \mathrm{R}_{\text {sigma }}=0.0294\right] \\
3056 / 1 / 240 \\
1.062 \\
\mathrm{R}_{1}=0.0550, \mathrm{wR}_{2}=0.1561 \\
\mathrm{R}_{1}=0.0561, \mathrm{wR}_{2}=0.1580 \\
0.39 /-0.43 \\
0.00(4)
\end{gathered}
$$

\begin{tabular}{|c|c|c|c|c|}
\hline Atom & $x$ & $y$ & $z$ & $\mathrm{U}(\mathrm{eq})$ \\
\hline $\mathrm{S} 1$ & 1318.1(12) & $4426.1(14)$ & $5184.2(4)$ & $41.9(3)$ \\
\hline $\mathrm{O} 1$ & $1765(7)$ & $5862(4)$ & $5622(2)$ & 56.1(9) \\
\hline $\mathrm{O} 2$ & $1758(7)$ & $2958(4)$ & $5601(2)$ & $54.7(9)$ \\
\hline N1 & $-1239(5)$ & $4431(8)$ & $4851(2)$ & $50.4(7)$ \\
\hline $\mathrm{C} 1$ & $2787(5)$ & $4461(7)$ & 4331.9(19) & $40.7(7)$ \\
\hline C6 & $3398(9)$ & $3064(7)$ & $3997(3)$ & $51.1(12)$ \\
\hline $\mathrm{C} 4$ & $5081(6)$ & $4527(8)$ & 2992(2) & $46.9(9)$ \\
\hline $\mathrm{C} 5$ & $4516(9)$ & $3102(6)$ & $3322(3)$ & $51.6(12)$ \\
\hline C3 & $4485(10)$ & $5903(7)$ & $3351(3)$ & $56.5(13)$ \\
\hline C14 & $1025(7)$ & $4307(8)$ & $-924(2)$ & $54.6(10)$ \\
\hline $\mathrm{C} 7$ & $6371(6)$ & $4576(9)$ & $2263(2)$ & $55.7(11)$ \\
\hline $\mathrm{C} 2$ & $3325(9)$ & $5886(6)$ & $4014(3)$ & $52.6(12)$ \\
\hline $\mathrm{C} 20$ & $8327(9)$ & $3492(11)$ & $2371(4)$ & $84(2)$ \\
\hline C15 & $-1065(10)$ & 4861(9) & $-1073(4)$ & $85(2)$ \\
\hline C19 & 1980(13) & $3850(8)$ & $-1599(3)$ & 84.1(19) \\
\hline $\mathrm{C} 17$ & $-1177(13)$ & $4447(12)$ & $-2511(3)$ & $90.8(19)$ \\
\hline C18 & $837(17)$ & 3902(9) & $-2376(4)$ & $98(2)$ \\
\hline C16 & $-2145(13)$ & 4933(13) & $-1864(5)$ & $109(3)$ \\
\hline $\mathrm{C} 8$ & $4883(6)$ & $4389(8)$ & $1460(2)$ & $50.1(9)$ \\
\hline $\mathrm{C} 11$ & $2281(7)$ & $4293(7)$ & $-91(2)$ & $51.0(10)$ \\
\hline C9 & $5291(10)$ & $3322(8)$ & $870(3)$ & $73(4)$ \\
\hline $\mathrm{C} 10$ & $4004(10)$ & $3288(8)$ & $119(3)$ & $68(4)$ \\
\hline C13 & $3096(10)$ & $5312(9)$ & $1279(3)$ & $80(5)$ \\
\hline C12 & 1843(9) & $5259(10)$ & $527(4)$ & $96(6)$ \\
\hline $\mathrm{F} 1$ & $134(16)$ & $6124(13)$ & $421(5)$ & $167(5)$ \\
\hline $\mathrm{C} 8^{\prime}$ & $4883(6)$ & 4389(8) & $1460(2)$ & $50.1(9)$ \\
\hline C11' & $2281(7)$ & $4293(7)$ & $-91(2)$ & $51.0(10)$ \\
\hline
\end{tabular}

Table S9. Fractional Atomic Coordinates $\left(\times 10^{4}\right)$ and Equivalent Isotropic Displacement Parameters $\left(\AA^{2} \times \mathbf{1 0}^{3}\right)$ for $\mathbf{C}_{20} \mathrm{H}_{18} \mathbf{F N O} 2 \mathrm{~S}(\mathbf{b 2 9})$. $U_{\text {eq }}$ is defined as $1 / 3$ of of the trace of the orthogonalised $\mathrm{U}_{\mathrm{IJ}}$ tensor. 


$\begin{array}{ccccc}\text { C13' } & 5291(10) & 3322(8) & 870(3) & 80(5) \\ \text { C12' } & 4004(10) & 3288(8) & 119(3) & 96(6) \\ \text { C9' } & 3096(10) & 5312(9) & 1279(3) & 73(4) \\ \text { C10' }^{\prime} & 1843(9) & 5259(10) & 527(4) & 68(4) \\ \text { F1 }^{\prime} & 4220(30) & 2150(20) & -349(8) & 167(5)\end{array}$

Table S10. Anisotropic Displacement Parameters $\left(\AA^{2} \times 10^{3}\right)$ for $\mathrm{C}_{20} \mathrm{H}_{18} \mathrm{FNO}_{2} \mathrm{~S}$ (b29). The Anisotropic displacement factor exponent takes the form: $-2 \pi^{2}\left[h^{2} a * 2 U_{11}+2 h k a * b * U_{12}+\ldots\right]$.

$\begin{array}{ccccccc}\text { Atom } & \mathrm{U}_{11} & \mathrm{U}_{22} & \mathrm{U}_{33} & \mathrm{U}_{23} & \mathrm{U}_{13} & \mathrm{U}_{12} \\ \mathrm{~S} 1 & 49.6(5) & 40.3(5) & 34.3(4) & -0.8(5) & -1.2(3) & -0.3(5) \\ \mathrm{O} 1 & 72(2) & 52(2) & 42.8(18) & -10.0(16) & 1.8(16) & -4.4(16) \\ \mathrm{O} 2 & 70(2) & 49(2) & 43.2(18) & 8.0(15) & 1.4(16) & 5.8(16) \\ \mathrm{N} 1 & 51.5(16) & 47(2) & 50.9(17) & 0(3) & 0.5(13) & -1(2) \\ \mathrm{C} 1 & 42.3(15) & 43.0(18) & 35.0(14) & -1(2) & -1.9(11) & -2(2) \\ \mathrm{C} 6 & 67(3) & 40(3) & 46(3) & 0(2) & 8(2) & -1(2) \\ \mathrm{C} 4 & 44.2(15) & 57(2) & 37.6(16) & 3(2) & -2.8(12) & -4(2) \\ \mathrm{C} 5 & 66(3) & 43(3) & 47(3) & -4(2) & 9(2) & -2(2) \\ \mathrm{C} 3 & 74(3) & 45(3) & 50(3) & 3(2) & 8(2) & -13(2) \\ \mathrm{C} 14 & 69(2) & 49(3) & 43.7(19) & 4(2) & 2.0(16) & -4(3) \\ \mathrm{C} 7 & 52.4(19) & 69(3) & 45.7(19) & 4(3) & 4.8(15) & -13(3) \\ \mathrm{C} 2 & 67(3) & 36(3) & 55(3) & -1(2) & 9(2) & 0(2) \\ \mathrm{C} 20 & 52(3) & 139(6) & 60(3) & 0(3) & 5(2) & 17(3) \\ \mathrm{C} 15 & 75(3) & 118(7) & 59(3) & 9(3) & 0(2) & 10(3) \\ \mathrm{C} 19 & 115(5) & 84(5) & 51(3) & -7(3) & 3(3) & 26(4) \\ \mathrm{C} 17 & 133(5) & 79(4) & 52(3) & 10(4) & -22(3) & -11(6) \\ \mathrm{C} 18 & 157(7) & 83(5) & 50(3) & -7(3) & -2(4) & 27(4) \\ \mathrm{C} 16 & 89(4) & 149(10) & 79(4) & 21(5) & -22(3) & 8(5) \\ \mathrm{C} 8 & 52.5(18) & 57(2) & 41.5(17) & 2(3) & 7.1(14) & -5(3) \\ \mathrm{C} 11 & 58.0(19) & 51(3) & 43.6(18) & -3(2) & 5.0(15) & -5(2) \\ \mathrm{C} 9 & 76(8) & 66(8) & 69(7) & 5(6) & -21(6) & 21(6) \\ \mathrm{C} 10 & 101(10) & 53(6) & 47(6) & -8(5) & -5(6) & 28(6) \\ \mathrm{C} 13 & 72(8) & 123(12) & 46(6) & -38(6) & 11(5) & 26(7) \\ \mathrm{C} 12 & 54(6) & 169(16) & 62(8) & -31(8) & -10(5) & 41(7) \\ \mathrm{F} 1 & 166(6) & 208(9) & 107(4) & -89(5) & -66(4) & 137(7) \\ \mathrm{C} 8{ }^{\prime} & 52.5(18) & 57(2) & 41.5(17) & 2(3) & 7.1(14) & -5(3) \\ \mathrm{C} 11^{\prime} & 58.0(19) & 51(3) & 43.6(18) & -3(2) & 5.0(15) & -5(2) \\ \mathrm{C} 13{ }^{\prime} & 72(8) & 123(12) & 46(6) & -38(6) & 11(5) & 26(7) \\ \mathrm{C} 12 & 54(6) & 169(16) & 62(8) & -31(8) & -10(5) & 41(7)\end{array}$




$\begin{array}{ccccccc}\text { C9' }^{\prime} & 76(8) & 66(8) & 69(7) & 5(6) & -21(6) & 21(6) \\ \text { C10' }^{\prime} & 101(10) & 53(6) & 47(6) & -8(5) & -5(6) & 28(6) \\ \text { F1' } & 166(6) & 208(9) & 107(4) & -89(5) & -66(4) & 137(7)\end{array}$

Table S11. Bond Lengths for $\mathrm{C}_{20} \mathrm{H}_{18} \mathrm{FNO}_{2} \mathrm{~S}$ (b29).

\begin{tabular}{|c|c|c|c|c|c|}
\hline \multicolumn{2}{|c|}{ Atom Atom } & \multirow{2}{*}{$\begin{array}{c}\text { Length/§ } \\
1.428(4)\end{array}$} & \multicolumn{2}{|c|}{ Atom Atom } & \multirow{2}{*}{$\begin{array}{c}\text { Length/ } \\
1.516(9)\end{array}$} \\
\hline $\mathrm{S} 1$ & $\mathrm{O} 1$ & & $\mathrm{C} 7$ & $\mathrm{C} 20$ & \\
\hline S1 & $\mathrm{O} 2$ & $1.435(4)$ & $\mathrm{C} 7$ & $\mathrm{C} 8$ & $1.526(5)$ \\
\hline $\mathrm{S} 1$ & $\mathrm{~N} 1$ & $1.611(3)$ & $\mathrm{C} 15$ & $\mathrm{C} 16$ & $1.392(9)$ \\
\hline $\mathrm{S} 1$ & $\mathrm{C} 1$ & $1.771(3)$ & C19 & $\mathrm{C} 18$ & $1.386(9)$ \\
\hline $\mathrm{C} 1$ & $\mathrm{C} 2$ & $1.378(8)$ & $\mathrm{C} 17$ & $\mathrm{C} 18$ & $1.324(12)$ \\
\hline $\mathrm{C} 1$ & C6 & $1.384(8)$ & $\mathrm{C} 17$ & $\mathrm{C} 16$ & $1.354(12)$ \\
\hline C6 & $\mathrm{C} 5$ & $1.386(8)$ & $\mathrm{C} 8$ & $\mathrm{C} 13$ & $1.360(8)$ \\
\hline $\mathrm{C} 4$ & $\mathrm{C} 3$ & $1.383(9)$ & $\mathrm{C} 8$ & $\mathrm{C} 9$ & $1.378(8)$ \\
\hline $\mathrm{C} 4$ & $\mathrm{C} 5$ & $1.392(8)$ & $\mathrm{C} 11$ & $\mathrm{C} 12$ & $1.364(7)$ \\
\hline $\mathrm{C} 4$ & $\mathrm{C} 7$ & $1.527(5)$ & $\mathrm{C} 11$ & $\mathrm{C} 10$ & $1.378(8)$ \\
\hline $\mathrm{C} 3$ & $\mathrm{C} 2$ & $1.383(8)$ & C9 & $\mathrm{C} 10$ & $1.387(8)$ \\
\hline $\mathrm{C} 14$ & $\mathrm{C} 15$ & $1.372(8)$ & $\mathrm{C} 13$ & $\mathrm{C} 12$ & $1.379(7)$ \\
\hline $\mathrm{C} 14$ & C19 & $1.382(8)$ & $\mathrm{C} 12$ & $\mathrm{~F} 1$ & $1.284(8)$ \\
\hline C14 & $\mathrm{C} 11$ & $1.492(6)$ & & & \\
\hline
\end{tabular}

Table S12. Bond Angles for $\mathrm{C}_{20} \mathrm{H}_{18} \mathrm{FNO}_{2} \mathrm{~S}$ (b29).

\begin{tabular}{|c|c|c|c|c|c|c|c|}
\hline \multicolumn{3}{|c|}{ Atom Atom Atom } & \multirow{2}{*}{$\begin{array}{c}\text { Angle/ }{ }^{\circ} \\
119.22(16)\end{array}$} & \multicolumn{3}{|c|}{ Atom Atom Atom } & \multirow{2}{*}{$\begin{array}{l}\text { Angle }^{\circ} \\
111.2(3)\end{array}$} \\
\hline $\mathrm{O} 1$ & $\mathrm{~S} 1$ & $\mathrm{O} 2$ & & $\mathrm{C} 8$ & $\mathrm{C} 7$ & $\mathrm{C} 4$ & \\
\hline $\mathrm{O} 1$ & $\mathrm{~S} 1$ & $\mathrm{~N} 1$ & $106.9(3)$ & $\mathrm{C} 1$ & $\mathrm{C} 2$ & $\mathrm{C} 3$ & $119.1(5)$ \\
\hline $\mathrm{O} 2$ & $\mathrm{~S} 1$ & N1 & $106.6(3)$ & $\mathrm{C} 14$ & $\mathrm{C} 15$ & $\mathrm{C} 16$ & $121.0(7)$ \\
\hline $\mathrm{O} 1$ & $\mathrm{~S} 1$ & $\mathrm{C} 1$ & $107.6(2)$ & $\mathrm{C} 14$ & C19 & $\mathrm{C} 18$ & $121.1(7)$ \\
\hline $\mathrm{O} 2$ & $\mathrm{~S} 1$ & $\mathrm{C} 1$ & $108.0(2)$ & $\mathrm{C} 18$ & $\mathrm{C} 17$ & $\mathrm{C} 16$ & $118.5(5)$ \\
\hline N1 & $\mathrm{S} 1$ & $\mathrm{C} 1$ & $108.16(16)$ & $\mathrm{C} 17$ & $\mathrm{C} 18$ & C19 & $121.8(7)$ \\
\hline $\mathrm{C} 2$ & $\mathrm{C} 1$ & C6 & $120.7(3)$ & $\mathrm{C} 17$ & $\mathrm{C} 16$ & $\mathrm{C} 15$ & $121.2(7)$ \\
\hline $\mathrm{C} 2$ & $\mathrm{C} 1$ & $\mathrm{~S} 1$ & $119.4(4)$ & $\mathrm{C} 13$ & $\mathrm{C} 8$ & $\mathrm{C} 9$ & $116.2(4)$ \\
\hline C6 & $\mathrm{C} 1$ & $\mathrm{~S} 1$ & $119.9(4)$ & C13 & $\mathrm{C} 8$ & $\mathrm{C} 7$ & $121.2(5)$ \\
\hline $\mathrm{C} 1$ & C6 & $\mathrm{C} 5$ & $119.4(5)$ & $\mathrm{C} 9$ & $\mathrm{C} 8$ & $\mathrm{C} 7$ & $122.5(5)$ \\
\hline $\mathrm{C} 3$ & $\mathrm{C} 4$ & $\mathrm{C} 5$ & 118.3(3) & $\mathrm{C} 12$ & $\mathrm{C} 11$ & $\mathrm{C} 10$ & $114.0(4)$ \\
\hline $\mathrm{C} 3$ & $\mathrm{C} 4$ & $\mathrm{C} 7$ & $120.7(5)$ & $\mathrm{C} 12$ & $\mathrm{C} 11$ & $\mathrm{C} 14$ & $123.7(5)$ \\
\hline $\mathrm{C} 5$ & $\mathrm{C} 4$ & $\mathrm{C} 7$ & $121.0(5)$ & $\mathrm{C} 10$ & C11 & $\mathrm{C} 14$ & $122.3(5)$ \\
\hline C6 & $\mathrm{C} 5$ & $\mathrm{C} 4$ & $120.8(5)$ & $\mathrm{C} 8$ & C9 & $\mathrm{C} 10$ & $120.6(5)$ \\
\hline
\end{tabular}




\begin{tabular}{|c|c|c|c|c|c|c|c|}
\hline $\mathrm{C} 2$ & $\mathrm{C} 3$ & $\mathrm{C} 4$ & $121.7(5)$ & $\mathrm{C} 11$ & $\mathrm{C} 10$ & $\mathrm{C} 9$ & $123.6(5)$ \\
\hline C15 & $\mathrm{C} 14$ & C19 & $116.3(5)$ & $\mathrm{C} 8$ & C13 & C12 & $122.0(5)$ \\
\hline $\mathrm{C} 15$ & C14 & $\mathrm{C} 11$ & $122.6(5)$ & $\mathrm{F} 1$ & $\mathrm{C} 12$ & C11 & $118.8(5)$ \\
\hline C19 & $\mathrm{C} 14$ & $\mathrm{C} 11$ & $120.9(5)$ & F1 & $\mathrm{C} 12$ & C13 & $117.7(6)$ \\
\hline $\mathrm{C} 20$ & $\mathrm{C} 7$ & $\mathrm{C} 8$ & $115.2(5)$ & $\mathrm{C} 11$ & $\mathrm{C} 12$ & C13 & $123.4(5)$ \\
\hline $\mathrm{C} 20$ & $\mathrm{C} 7$ & $\mathrm{C} 4$ & $112.5(4)$ & & & & \\
\hline
\end{tabular}

Table S13. Hydrogen Bonds for $\mathrm{C}_{20} \mathrm{H}_{18} \mathrm{FNO}_{2} \mathrm{~S}$ (b29).

$\begin{array}{lllllll}\mathrm{D} & \mathrm{H} & \mathrm{A} & \mathrm{d}(\mathrm{D}-\mathrm{H}) / \AA & \mathrm{d}(\mathrm{H}-\mathrm{A}) / \AA & \mathrm{d}(\mathrm{D}-\mathrm{A}) / \AA & \mathrm{D}-\mathrm{H}-\mathrm{A} /{ }^{\circ}\end{array}$

$\begin{array}{llll}\mathrm{N} 1 \mathrm{H} 1 \mathrm{~A} \mathrm{O} 1^{1} & 0.90(7) & 2.26(7) & 3.140(8)\end{array}$

$\mathrm{N} 1 \mathrm{H}_{1 \mathrm{~B} \mathrm{O}} 2^{2} \quad 0.84(8) \quad 2.32(8) \quad 3.098(8) \quad 153(7)$

${ }^{1}-\mathrm{X},-1 / 2+\mathrm{Y}, 1-\mathrm{Z} ;{ }^{2}-\mathrm{X}, 1 / 2+\mathrm{Y}, 1-\mathrm{Z}$

Table S14. Hydrogen Atom Coordinates $\left(\AA \times 10^{4}\right)$ and Isotropic Displacement Parameters $\left(\AA^{2} \times 1^{3}\right)$ for $\mathrm{C}_{20} \mathrm{H}_{18} \mathrm{FNO}_{2} \mathrm{~S}(\mathrm{~b} 29)$.

\begin{tabular}{|c|c|c|c|c|}
\hline Atom & $x$ & $y$ & $z$ & $\mathrm{U}(\mathrm{eq})$ \\
\hline H6 & 3061 & 2107 & 4223 & 61 \\
\hline H5 & 4895 & 2164 & 3087 & 62 \\
\hline H3 & 4874 & 6863 & 3143 & 68 \\
\hline $\mathrm{H} 7$ & 6961 & 5644 & 2255 & 67 \\
\hline $\mathrm{H} 2$ & 2913 & 6823 & 4241 & 63 \\
\hline $\mathrm{H} 20 \mathrm{~A}$ & 7849 & 2420 & 2312 & 126 \\
\hline H20B & 9116 & 3643 & 2904 & 126 \\
\hline $\mathrm{H} 20 \mathrm{C}$ & 9255 & 3728 & 1963 & 126 \\
\hline H15 & -1770 & 5194 & -639 & 102 \\
\hline H19 & 3413 & 3502 & -1530 & 101 \\
\hline H17 & -1909 & 4495 & -3037 & 109 \\
\hline H18 & 1502 & 3544 & -2815 & 118 \\
\hline H16 & -3557 & 5321 & -1950 & 131 \\
\hline H9 & 6440 & 2618 & 976 & 88 \\
\hline H10 & 4320 & 2547 & -263 & 82 \\
\hline H13 & 2708 & 6001 & 1673 & 96 \\
\hline H13' & 6440 & 2618 & 976 & 96 \\
\hline H9' & 2708 & 6001 & 1673 & 88 \\
\hline H10' & 637 & 5915 & 437 & 82 \\
\hline $\mathrm{H} 1 \mathrm{~A}$ & $-1570(90)$ & $3480(80)$ & $4630(40)$ & $46(15)$ \\
\hline H1B & $-1630(110)$ & $5250(90)$ & $4590(50)$ & $62(19)$ \\
\hline
\end{tabular}


Table S15. Atomic Occupancy for $\mathrm{C}_{20} \mathrm{H}_{18} \mathrm{FNO}_{2} \mathrm{~S}$ (b29).

$\begin{array}{cccccc}\text { Atom } & \text { Occupancy } & \text { Atom } & \text { Occupancy } & \text { Atom } & \text { Occupancy } \\ \text { C8 } & 0.618(8) & \text { C11 } & 0.618(8) & \text { C9 } & 0.618(8) \\ \text { H9 } & 0.618(8) & \text { C10 } & 0.618(8) & \text { H10 } & 0.618(8) \\ \text { C13 } & 0.618(8) & \text { H13 } & 0.618(8) & \text { C12 } & 0.618(8) \\ \text { F1 } & 0.618(8) & \text { C8' }^{\prime} & 0.382(8) & \text { C11' }^{\prime} & 0.382(8) \\ \text { C13' } & 0.382(8) & \text { H13' } & 0.382(8) & \text { C12' }^{\prime} & 0.382(8) \\ \text { C9' }^{\prime} & 0.382(8) & \text { H9' }^{\prime} & 0.382(8) & \text { C10' } & 0.382(8) \\ \text { H10' }^{\prime} & 0.382(8) & \text { F1' } & 0.382(8) & & \end{array}$

\section{General Information for $b 35$}

\subsection{Materials and analytical information}

Rink amide AM resin was purchased from Hecheng Technology (Tianjing, China). Fmoc-amino acids were purchased from C S Bio, GL Biochem (Shanghai, China). $O$-(6-Chlorobenzotriazol-1-yl)- $N, N, N^{\prime}, N^{\prime}$-tetramethyluronium hexafluorophosphate (HCTU) was purchased from GL Biochem (Shanghai, China). N, N-Diisopropylethylamine (DIEA) was purchased from Ouhe Technology (Beijing, China). Acetonitrile (HPLC grade) was purchased from J. T. Baker (Phillipsburg, NJ, USA). N, N-Dimethylformamide (DMF), dichloromethane (DCM) were purchased from Sinopharm Chemical Reagent. Thioanisole and trifluoroacetic acid (TFA) (HPLC grade) were purchased from J\&K Scientific (Beijing, China).

Reversed phase HPLC was performed on Shimadzu Prominence HPLC systems. For peptide analysis, Vydac C18 $(4.6 \times 250 \mathrm{~mm})$ columns were used at a flow rate of $1.0 \mathrm{~mL} / \mathrm{min}$. For peptide purification, Vydac $\mathrm{C} 18(10 \times 250 \mathrm{~mm})$ columns were used. Water (with $0.1 \%$ TFA) and acetonitrile (with $0.1 \%$ TFA) were used as the mobile phase. ESI-MS spectra were recorded on an Agilent 1200 Series HPLC system with LC-MS. 


\subsection{Procedures and characterization data of $b 35$}

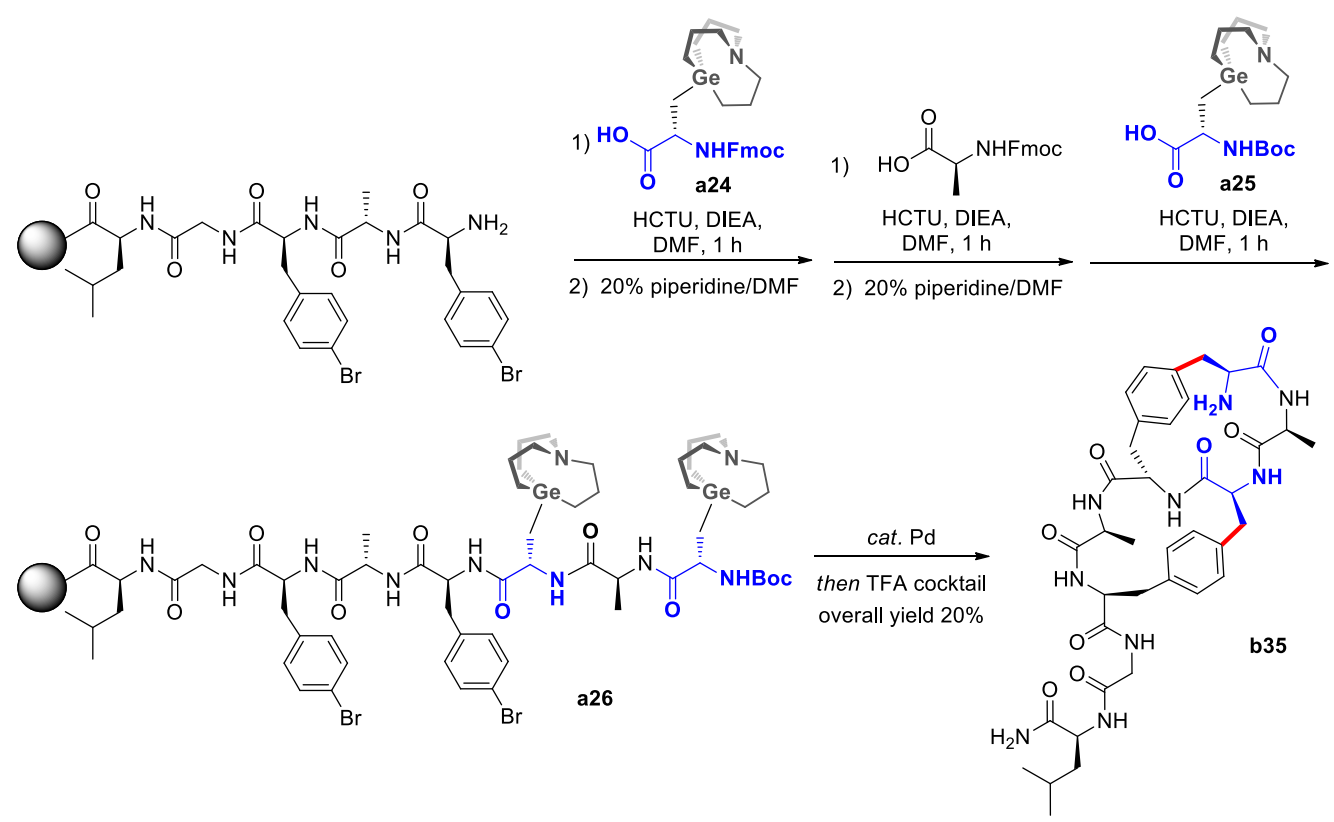

Figure S3. The procedure for the preparation of bicyclic peptide $b 35$.

The peptide was manually assembled by Fmoc-SPPS. Rink amide AM resin with loading $0.33 \mathrm{mmol} / \mathrm{g}(152 \mathrm{mg})$ was swelled in a mixture of DCM/DMF $(3 \mathrm{~mL} / 3 \mathrm{~mL})$ for $0.5 \mathrm{~h}$, then $20 \%$ piperidine/DMF solution was added to remove $\mathrm{N}$-terminal Fmoc group for reacting $5 \mathrm{~min}$. After $10 \mathrm{~min}, 20 \%$ piperidine/DMF solution was added again. Subsequently, the resin was washed with DMF (5 times), $\mathrm{CH}_{2} \mathrm{Cl}_{2}$ (5 times) and DMF (5 times). After that, a pre-activated solution of the Fmoc-Leu-OH (4 equiv.), HCTU (3.8 equiv.) and DIEA ( 8 equiv.) in DMF ( $3 \mathrm{~mL}$ ) was added to the resin for reacting 1 hour, then $20 \%$ piperidine/DMF solution was added to remove N-terminal Fmoc group for reacting $5 \mathrm{~min}$. After $10 \mathrm{~min}, 20 \%$ piperidine/DMF solution was added again. After that, the resin was washed with DMF (5 times), $\mathrm{CH}_{2} \mathrm{Cl}_{2}$ (5 times) and DMF (5 times). Other Fmoc amino acids were coupled as the procedure of Fmoc-Leu-OH. The assembled peptide was not cleaved from resin before Pd-catalyzed cross-coupling reaction.

Pd-catalyzed cross-coupling reaction was performed in an oven-dried screw-cap tube. The assembled peptide ( $0.05 \mathrm{mmol}, 1$ equiv.), $\mathrm{Pd}(\mathrm{dba})_{2}(5 \mathrm{~mol} \%)$ and Ligand $\mathrm{L}_{10}(15 \mathrm{~mol} \%)$ were weighed and transferred to the screw-cap tube with stir bar. The tube was evacuated and backfilled three times with argon, then DMF (1 mL) was added and the screw-cap tube was sealed with a Teflon stopper and heated to $120{ }^{\circ} \mathrm{C}$ for $16 \mathrm{~h}$. The reaction solution was filtered and the crude product was washed with EtOAc for 3 times. After that, the crude peptide was cleaved from resin by using cleavage cocktail (TFA/phenol/water/thioanisole/EDT, 82.5:5:5:5:2.5) for $3 \mathrm{~h}$. Then the cleavage solution was collected and concentrated by blowing with $\mathrm{N}_{2}$. The crude bicyclic peptide was obtained after cold $\mathrm{Et}_{2} \mathrm{O}$ treatment. Analysis and purification was carried out using HPLC (a linear gradient from 10\% to $40 \%$ acetonitrile in $0.1 \%$ trifluoroacetic acid, $30 \mathrm{~min}$ C18) and MS. The purified bicyclic peptide b35 was obtained with an overall yield $20 \%(7.6 \mathrm{mg})$ as white solid. 


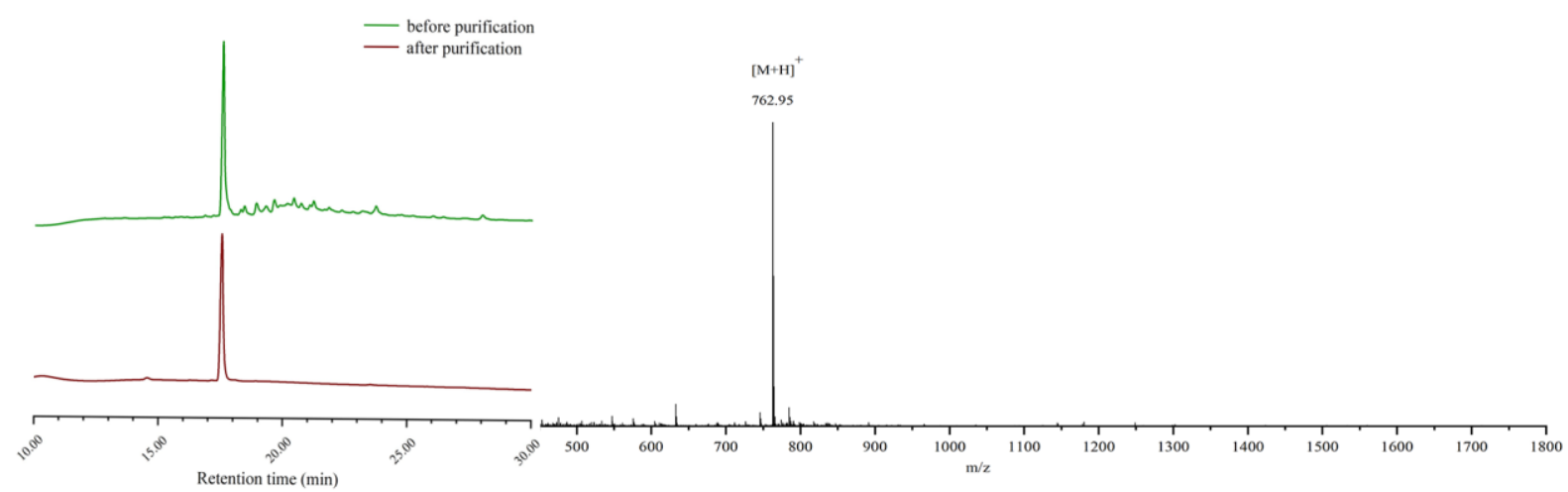

Figure S4. HPLC and mass spectrum of bicyclic p/eptide b35.

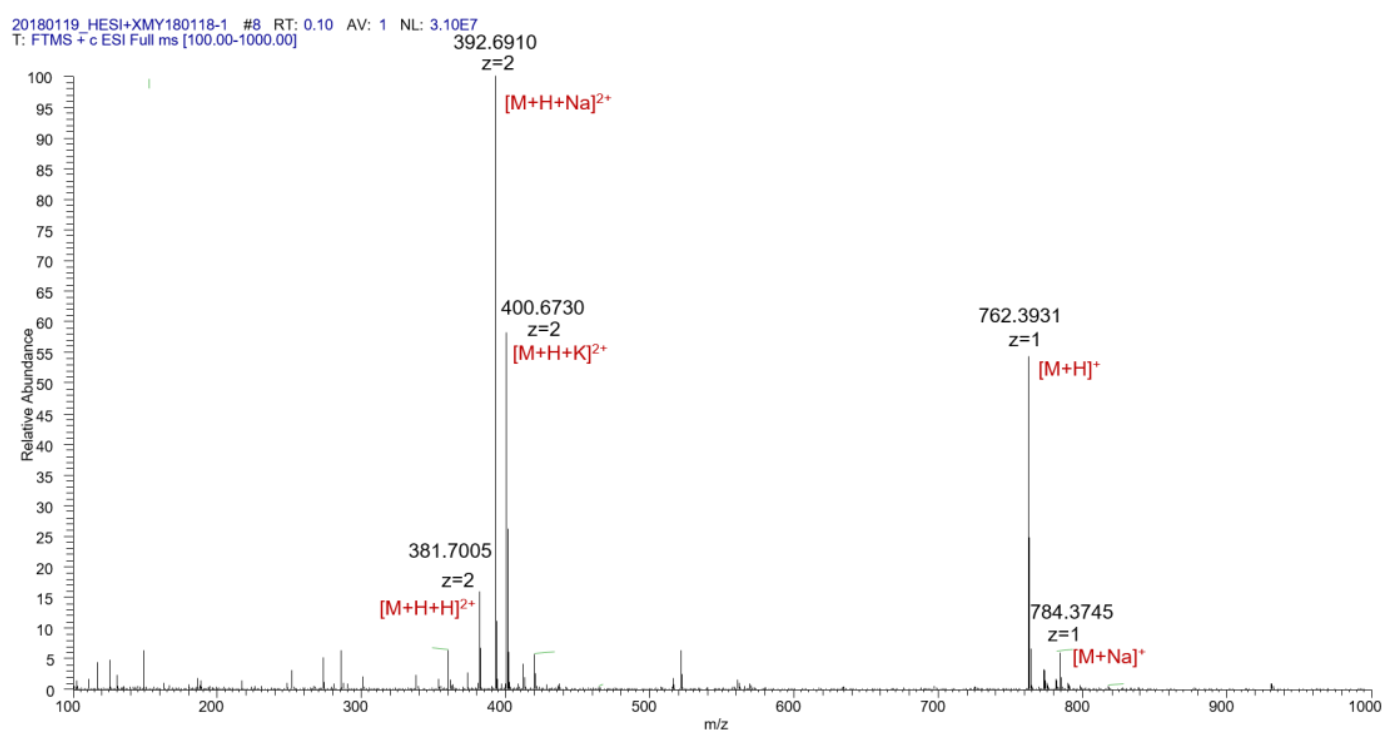

Figure S5. HRMS (ESI) of bicyclic peptide b35. Calcd for $\left[\mathrm{C}_{38} \mathrm{H}_{53} \mathrm{~N}_{9} \mathrm{O}_{8}\right]^{2+}[\mathrm{M}+\mathrm{H}+\mathrm{H}]^{2+}: \mathrm{m} / \mathrm{z}$ 381.7009; Found: m/z 381.7005; Calcd for $\left[\mathrm{C}_{38} \mathrm{H}_{52} \mathrm{~N}_{9} \mathrm{NaO}_{8}\right]^{2+}[\mathrm{M}+\mathrm{H}+\mathrm{Na}]^{2+}: \mathrm{m} / \mathrm{z}$ 392.6919; Found: $\mathrm{m} / \mathrm{z}$ 392.6910; Calcd for $\left[\mathrm{C}_{38} \mathrm{H}_{52} \mathrm{~N}_{9} \mathrm{KO}_{8}\right]^{2+}[\mathrm{M}+\mathrm{H}+\mathrm{K}]^{2+}: \mathrm{m} / \mathrm{z}$ 400.6788; Found: $\mathrm{m} / \mathrm{z}$ 400.6730; Calcd for $\left[\mathrm{C}_{38} \mathrm{H}_{52} \mathrm{~N}_{9} \mathrm{O}_{8}\right]^{+}[\mathrm{M}+\mathrm{H}]^{+}:$762.3939; Found: 762.3931; Calcd for $\left[\mathrm{C}_{38} \mathrm{H}_{51} \mathrm{~N}_{9} \mathrm{NaO}_{8}\right]^{2+}[\mathrm{M}+\mathrm{Na}]^{2+}:$ 784.3758; Found: 784.3745 . 


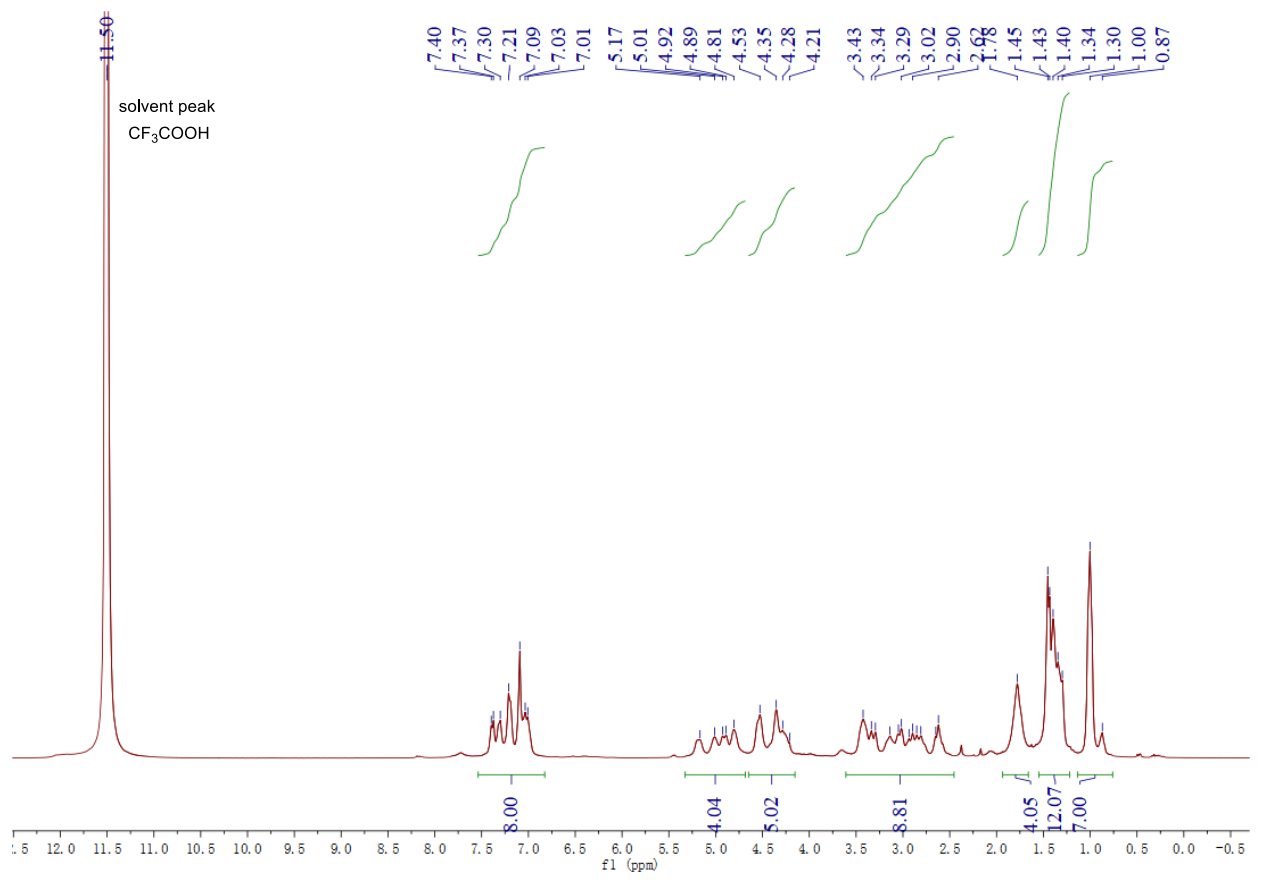

Figure S6. ${ }^{1} \mathrm{H}$ NMR (300 MHz, CF $\mathbf{3}$ COOD) of bicyclic peptide b35. $\delta 7.58-6.87(\mathrm{~m}, 8 \mathrm{H}), 5.30$ $-4.71(\mathrm{~m}, 4 \mathrm{H}), 4.53-4.20(\mathrm{~m}, 5 \mathrm{H}), 3.59-2.53(\mathrm{~m}, 9 \mathrm{H}), 1.80-1.50(\mathrm{~m}, 4 \mathrm{H}), 1.65-1.13(\mathrm{~m}, 12 \mathrm{H})$, $1.10-0.80(\mathrm{~m}, 7 \mathrm{H})$.

\section{References}

1. Burch, P., Binaghi, M., Scherer, M., Wentzel, C., Bossert, D., Eberhardt, L., Neuburger, M., Scheiffele, P., Gademann, K. Total Synthesis of Gelsemiol. Chem. Eur. J. 2013, 19, 2589-2591.

2. Wang, X-L., Ji, X-M., Shao, C-D., Zhang, Y., Zhang, Y-H. Palladium-catalyzed C-H alkylation of 2-phenylpyridines with alkyl iodides. Org. Biomol. Chem. 2017, 15, 5616-5624.

3. Shang, R., Huang, Z., Xiao, X., Lu, X., Fu, Y., Liu, L. $\beta$ - Aryl Nitrile Construction via Palladium-Catalyzed Decarboxylative Benzylation of $\alpha$ - Cyano Aliphatic Carboxylate Salts. Adv. Synth. Catal. 2012, 13, 2465-2472.

4. Zhang, Z-Q., Yang, C-T., Liang, L-J., Xiao, B., Lu, X., Liu, J-H., Sun, Y-Y., Marder, T. B., Yao, F. Copper-Catalyzed/Promoted Cross-coupling of gem-Diborylalkanes with Nonactivated Primary Alkyl Halides: An Alternative Route to Alkylboronic Esters. Org. Lett. 2014, 16, 6342-6345.

5. Fenster, E., Fehl, C., Aube, J. Use of a Tandem Prins/Friedel-Crafts Reaction in the Construction of the Indeno-Tetrahydropyridine Core of the Haouamine Alkaloids: Formal Synthesis of (-)-Haouamine A. Org. Lett. 2011, 13, 2614-2617.

6._Lu, X., Yi, J., Zhang, Z-Q., Dai, J-J., Liu, J-H., Xiao, B., Fu, Y., Liu, L. Expedient Synthesis of Chiral $\alpha$-Amino Acids through Nickel-Catalyzed Reductive Cross-Coupling. Chem. Eur. J. 2014, 20, 15339-15343.

7. Aiguabella, N., Pesquer, A., Verdaguer, X., Riera, A. Pauson-Khand Adducts of N-Boc-propargylamine: A New Approach to 4, 5-Disubstituted Cyclopentenones. Org. Lett. 2013, 15, 2696-2699.

8. Hao, X-W., Yuan, J., Yu, G-A., Qiu, M-Q., She, N-F., Sun, Y., Zhao, C., Mao, S-L., Yin, J., 
Liu, S-H. Air-stable and highly efficient indenyl-derived phosphine ligand: Application to Buchwald-Hartwig amination reactions. Journal of Organometallic Chemistry 2012, 706-707, 99-105.

9. Liu, Y., Peng, H., Yuan, J., Yan, M-Q., Luo, X., Wu, Q-G., Liu, S-H., Chen, J., Yu, G-A. An efficient indenyl-derived phosphine ligand for the Suzuki-Miyaura coupling of sterically hindered aryl halides. Org. Biomol. Chem. 2016, 14, 4664-4668.

10. Schmidt, B., Krehl, S., Kelling, A., Schilde, U. Synthesis of 8-aryl-substituted coumarins based on ring-closing metathesis and Suzuki-Miyaura coupling: synthesis of a furyl coumarin natural product from Galipea panamensis. J. Org. Chem. 2012, 77, 2360-2367.

11. Scholz, M., Blobaum, A. L., Marnett, L. J., Hey-Hawkins, E. ortho-Carbaborane derivatives of indomethacin as cyclooxygenase (COX)-2 selective inhibitors. Bioorganic \& medicinal chemistry 2012, 20, 4830-4837.

12. Bacsa, I., Jojart, R., Schneider, G., Wolfling, J., Maroti, P., Herman, B. E., Szecsi, M.,

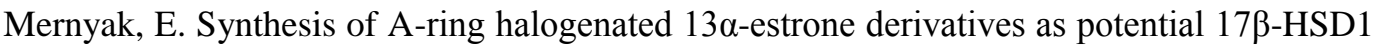
inhibitors. Steroids 2015, 104, 230-236.

13. Goldberg, N. W., Shen, X., Li, J., Ritter, T. AlkylFluor: Deoxyfluorination of Alcohols. Org. Lett. 2016, $18,6102$.

14. Dolomanov, O. V., Bourhis, L. J., Gildea, R. J., Howard, J. A., Puschmann, H. OLEX2: a complete structure solution, refinement and analysis program, computer programs. J. Appl. Cryst. 2009, 42, 339-341.

15. Sheldrick, G. M. SHELXT: Integrating space group determination and structure solution. Acta Cryst. 2014, A70, C1437.

16. Sheldrick, G. M. SHELXT-Integrated space-group and crystal-structure determination. Acta Cryst. 2015, A71, 3-8.

\section{Spectral Data}




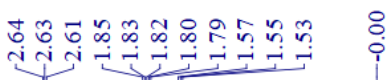
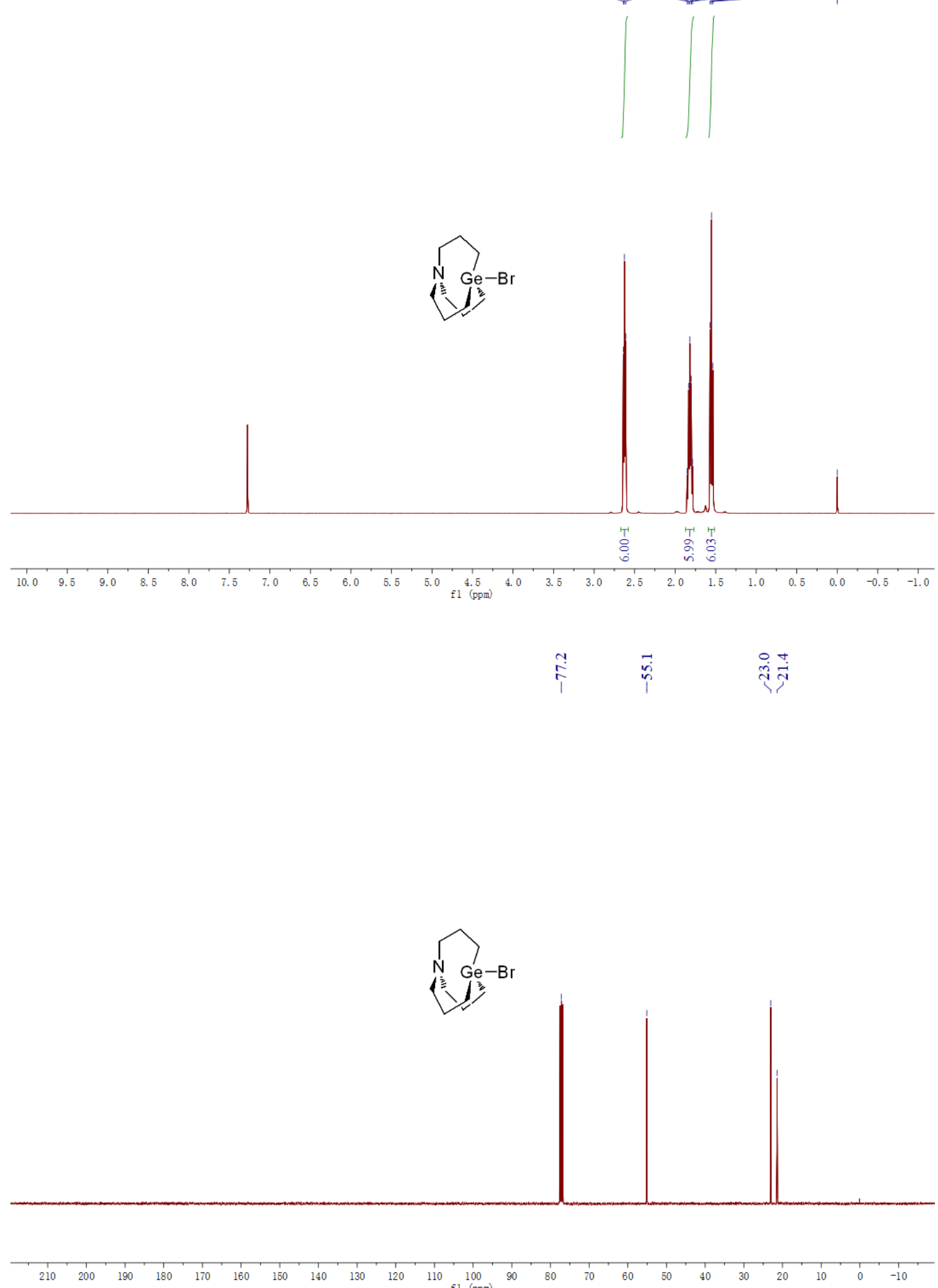
m.

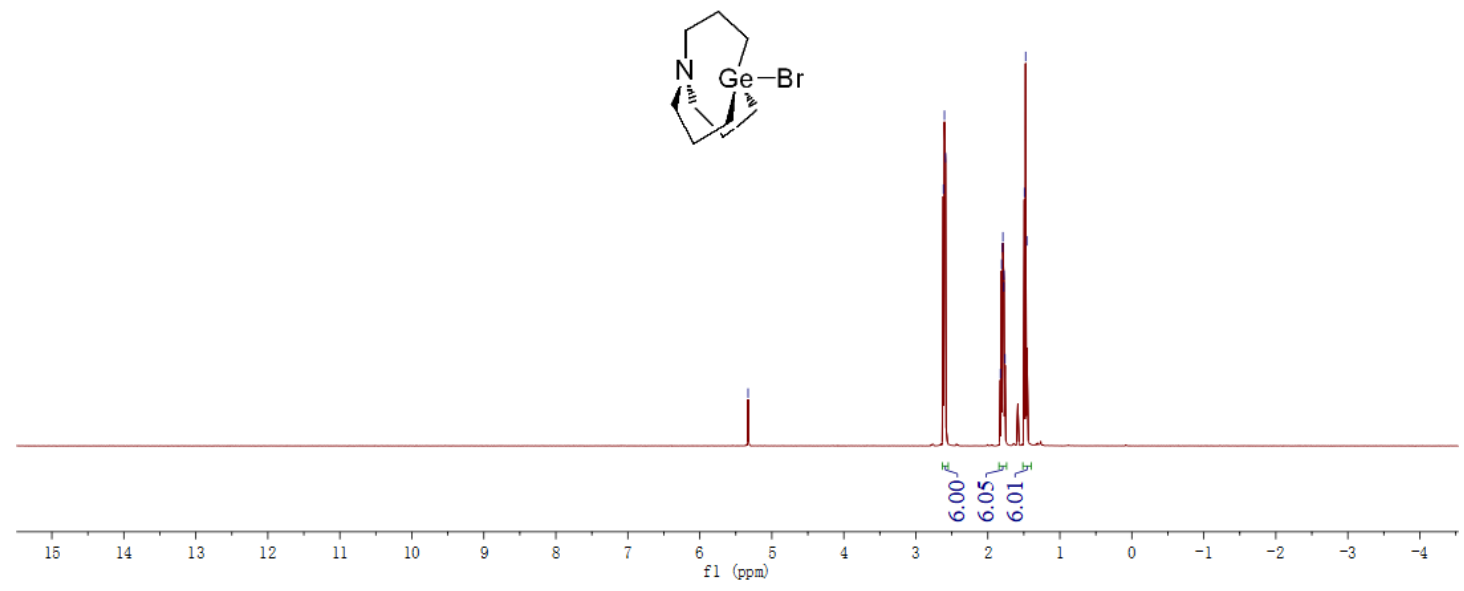

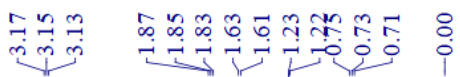
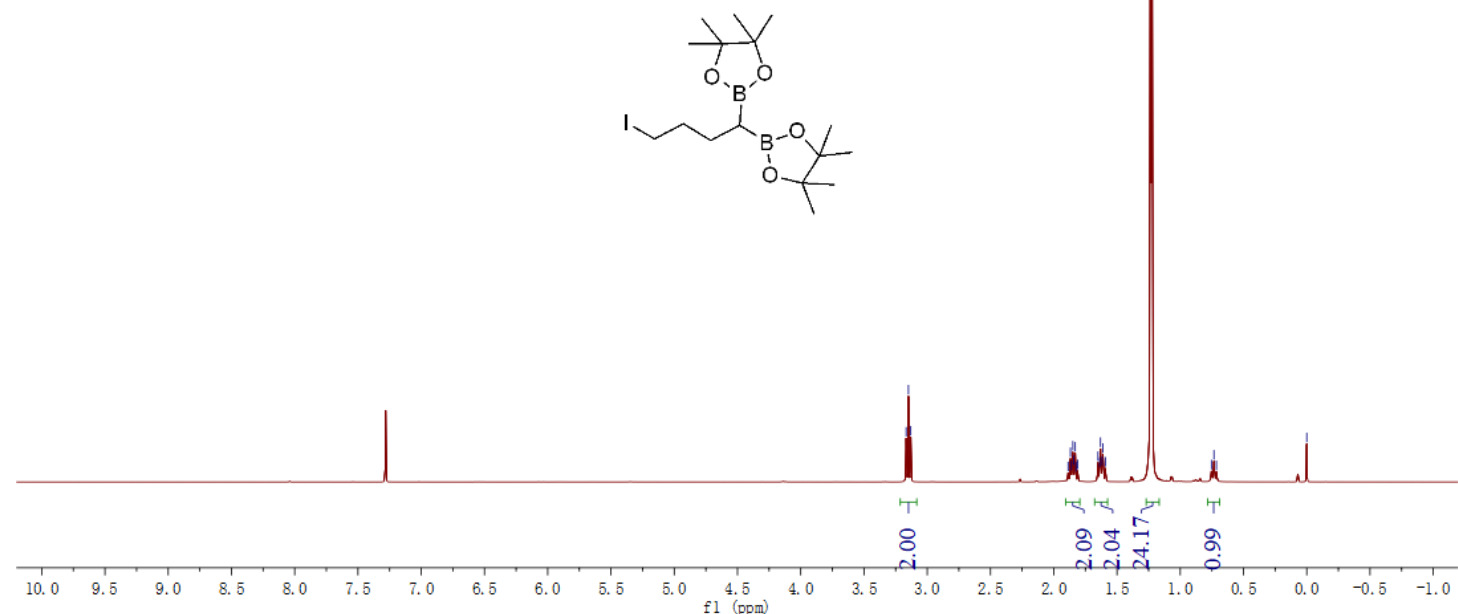


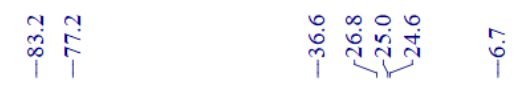

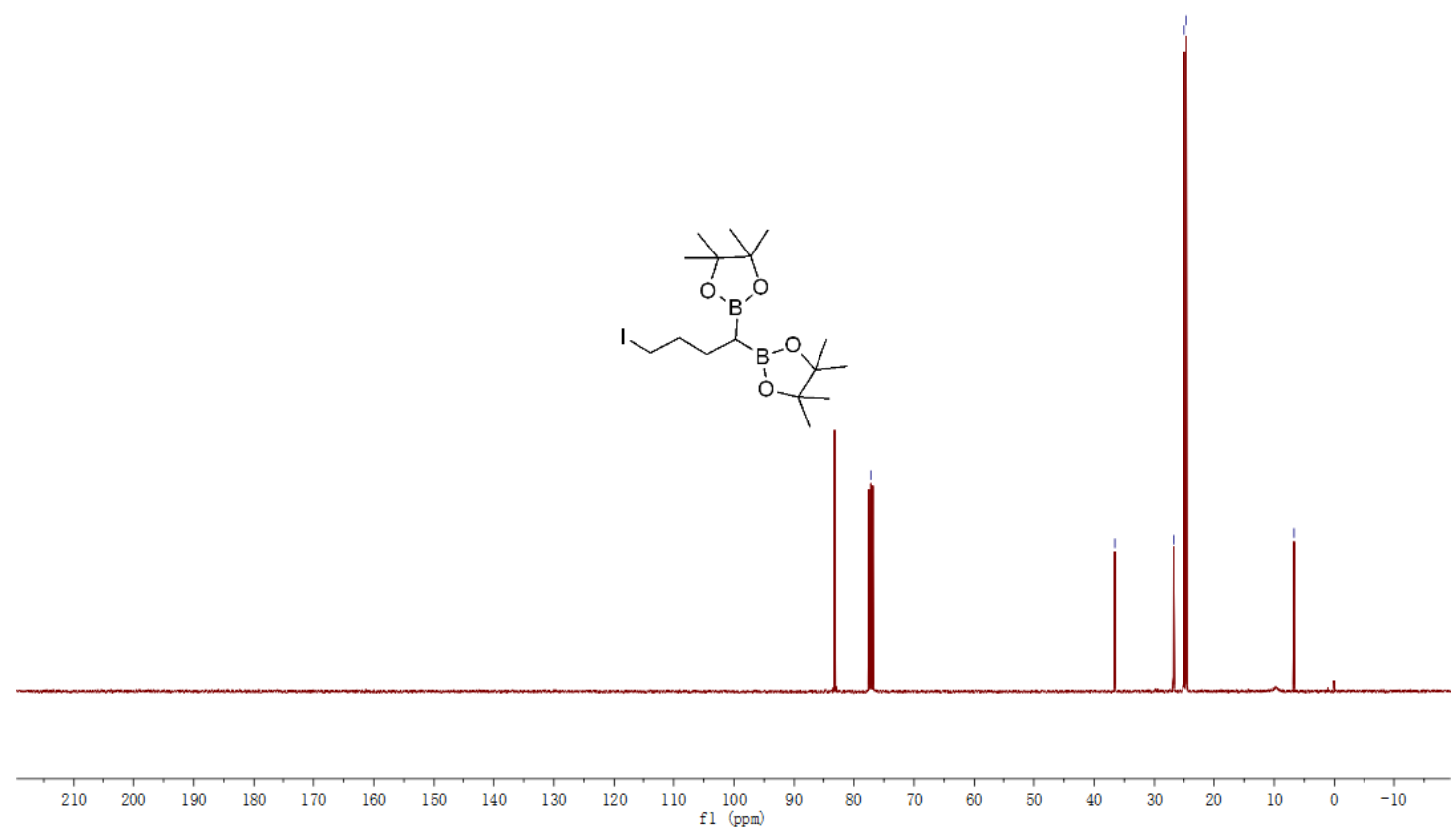

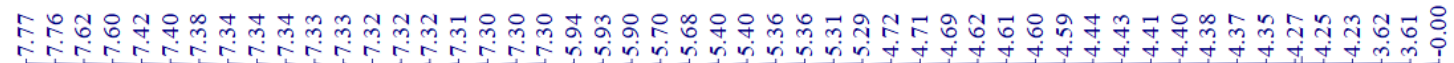
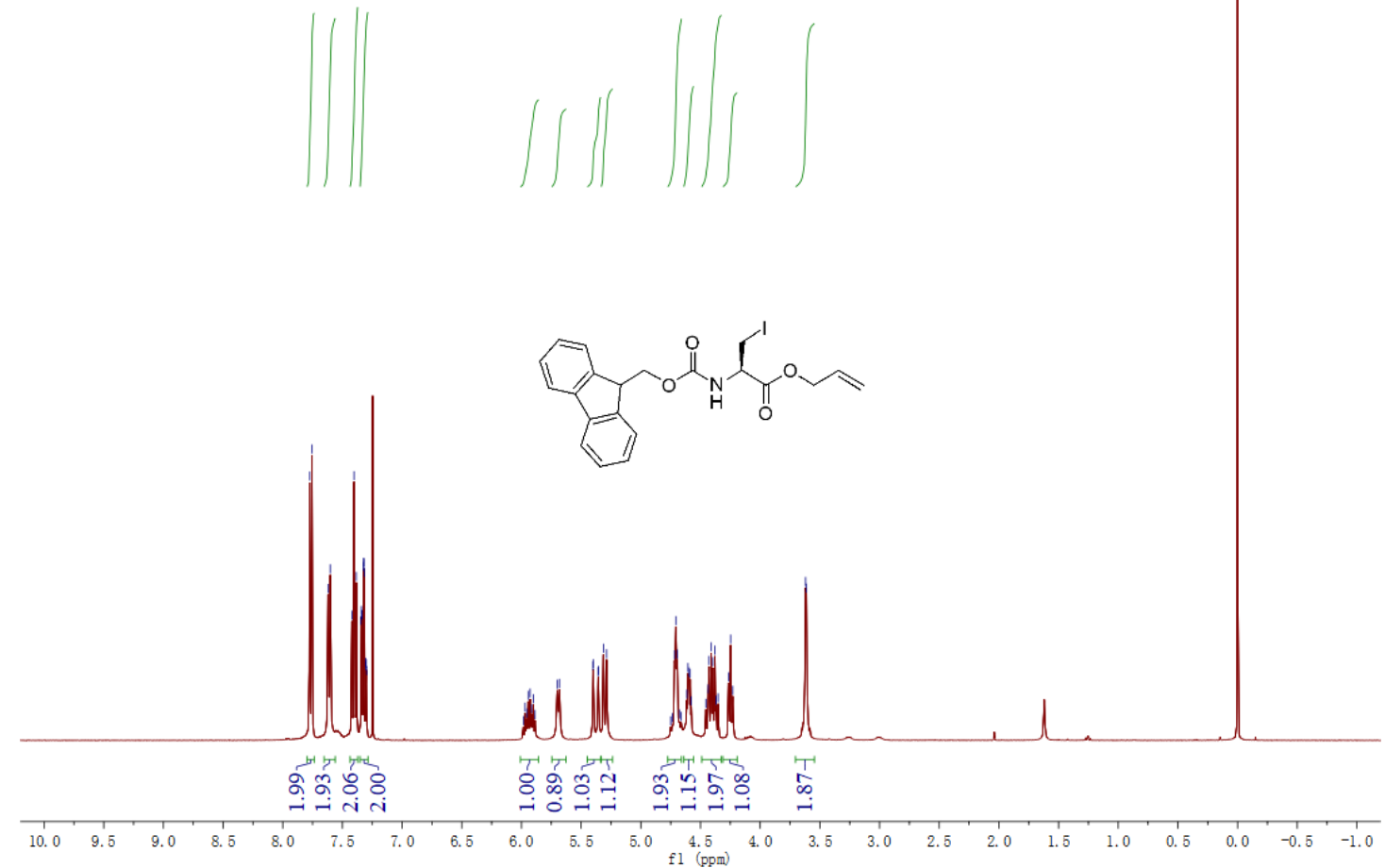


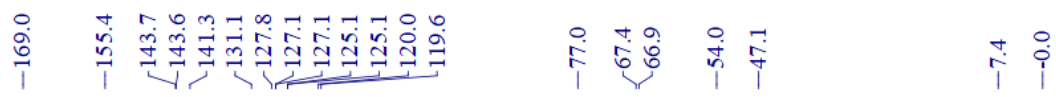
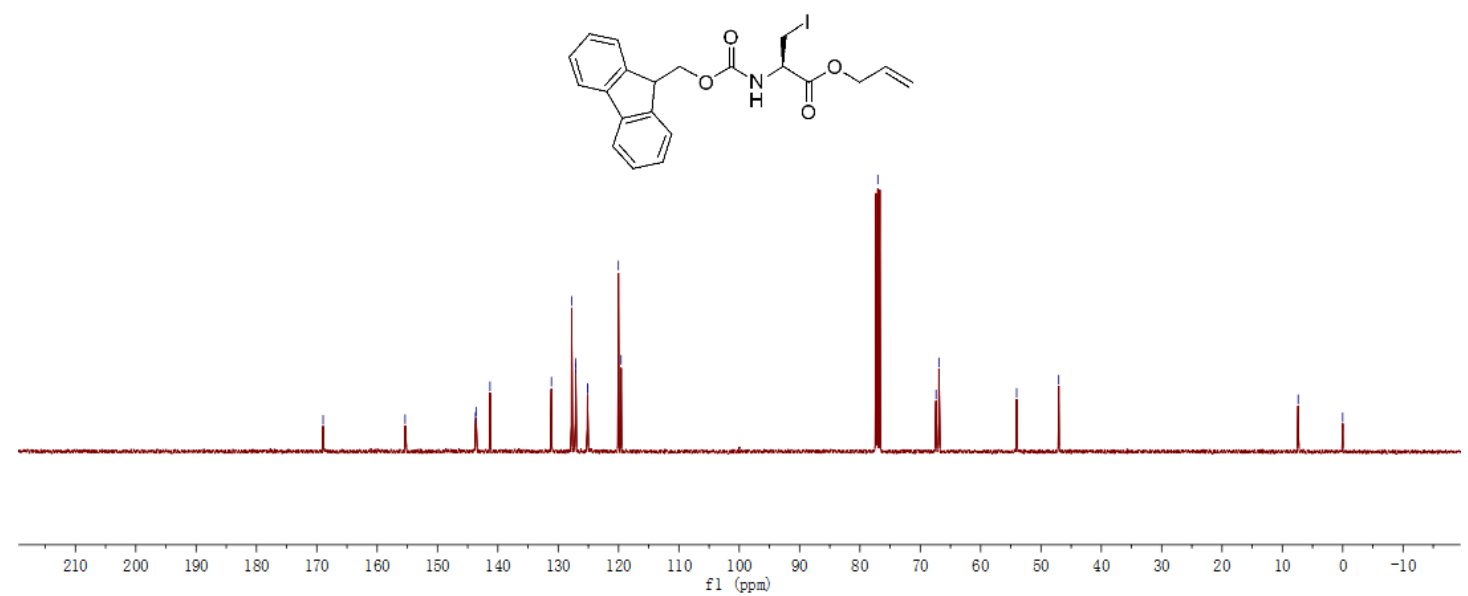

구워
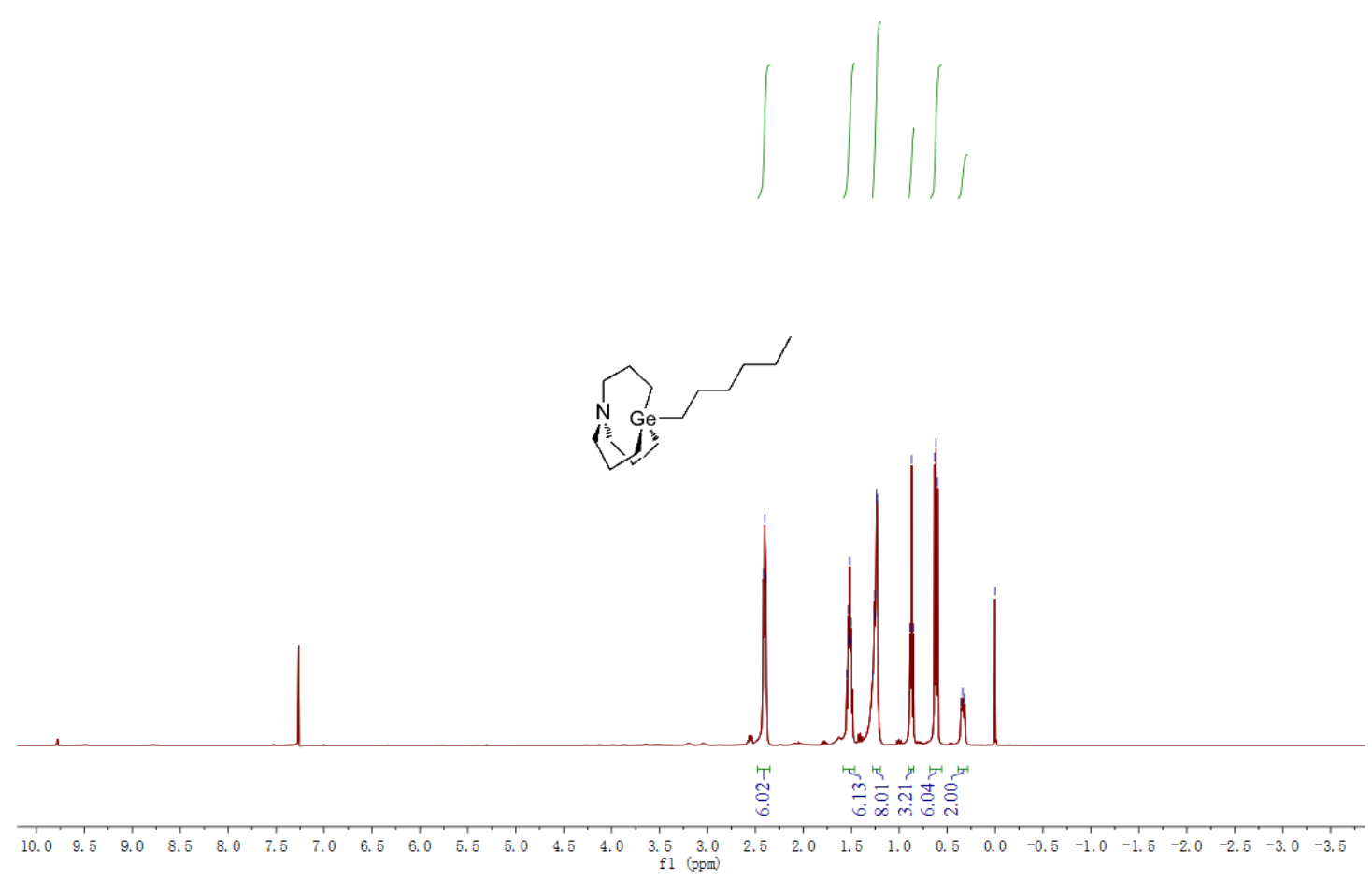

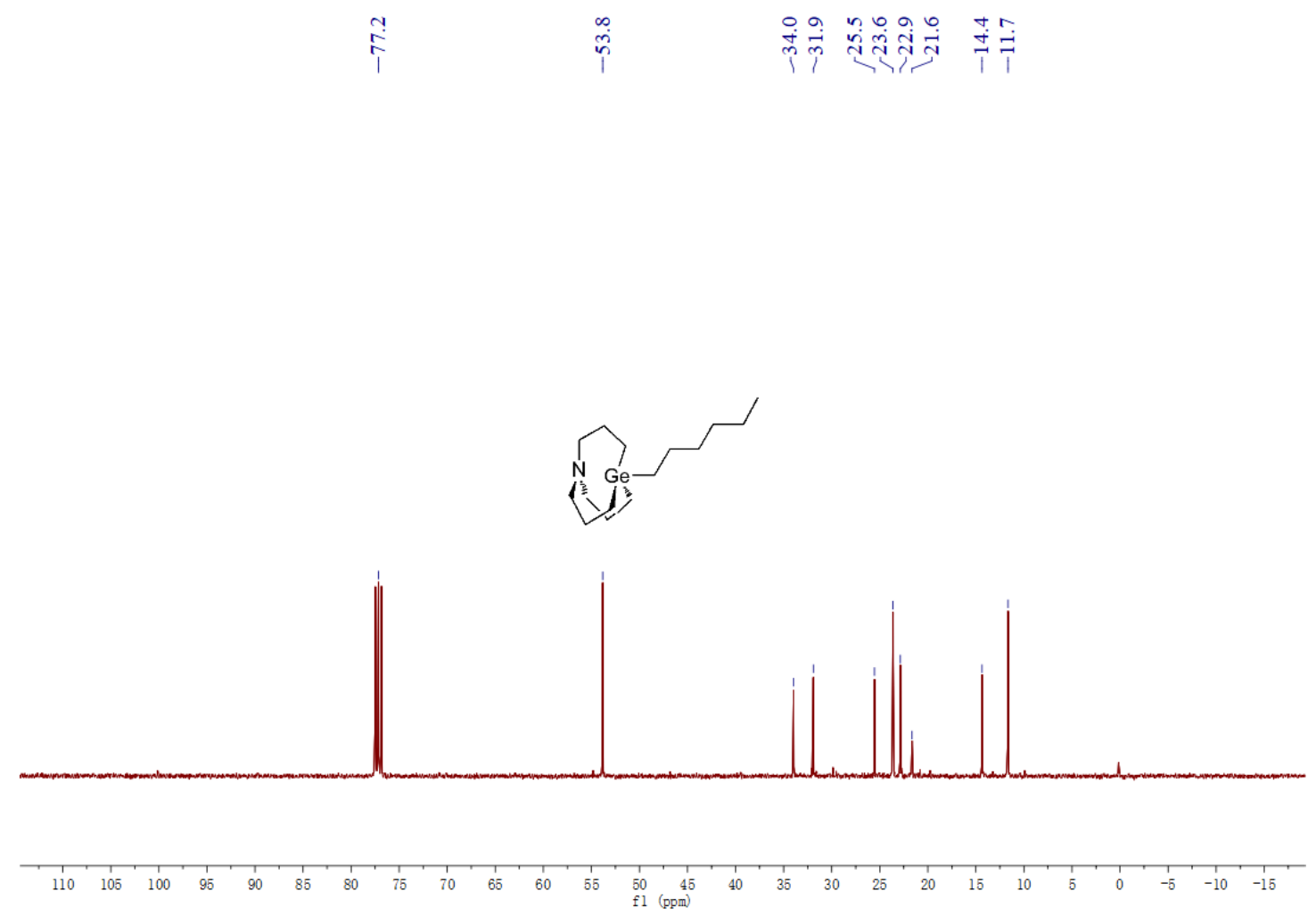

$\stackrel{0}{i}$

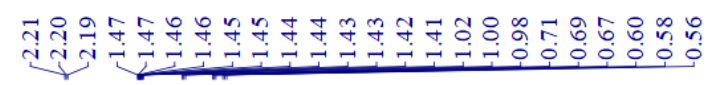
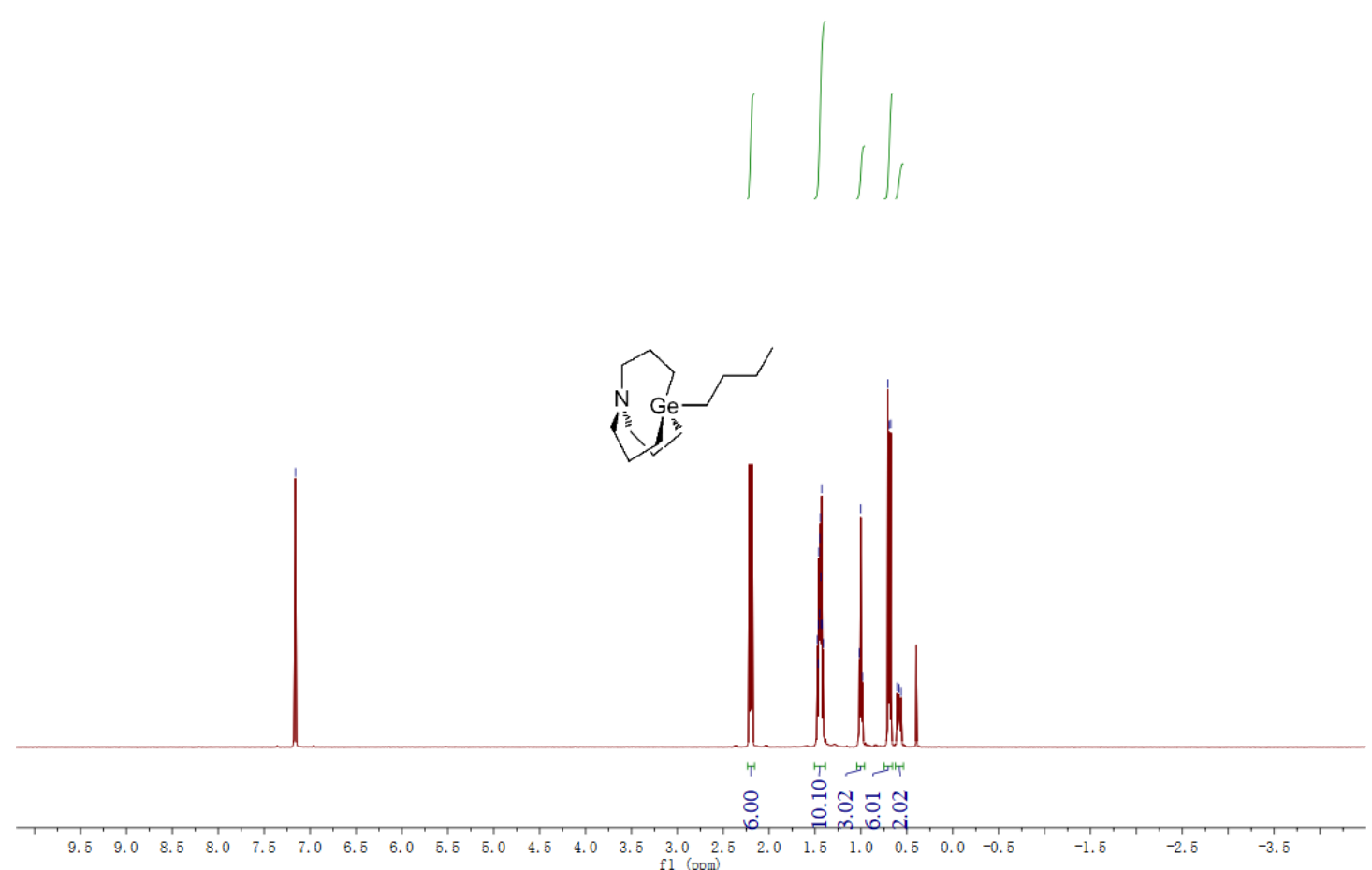

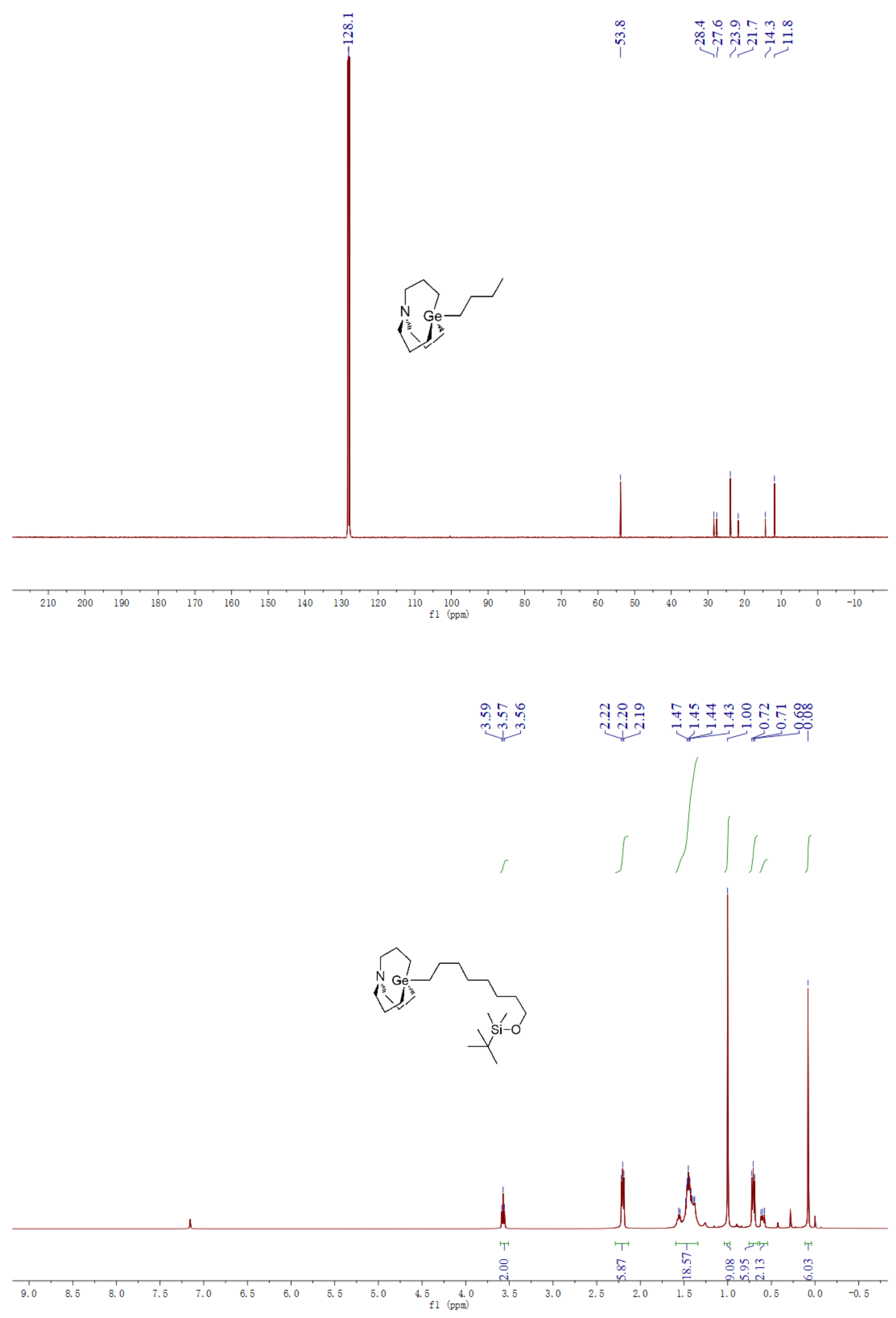

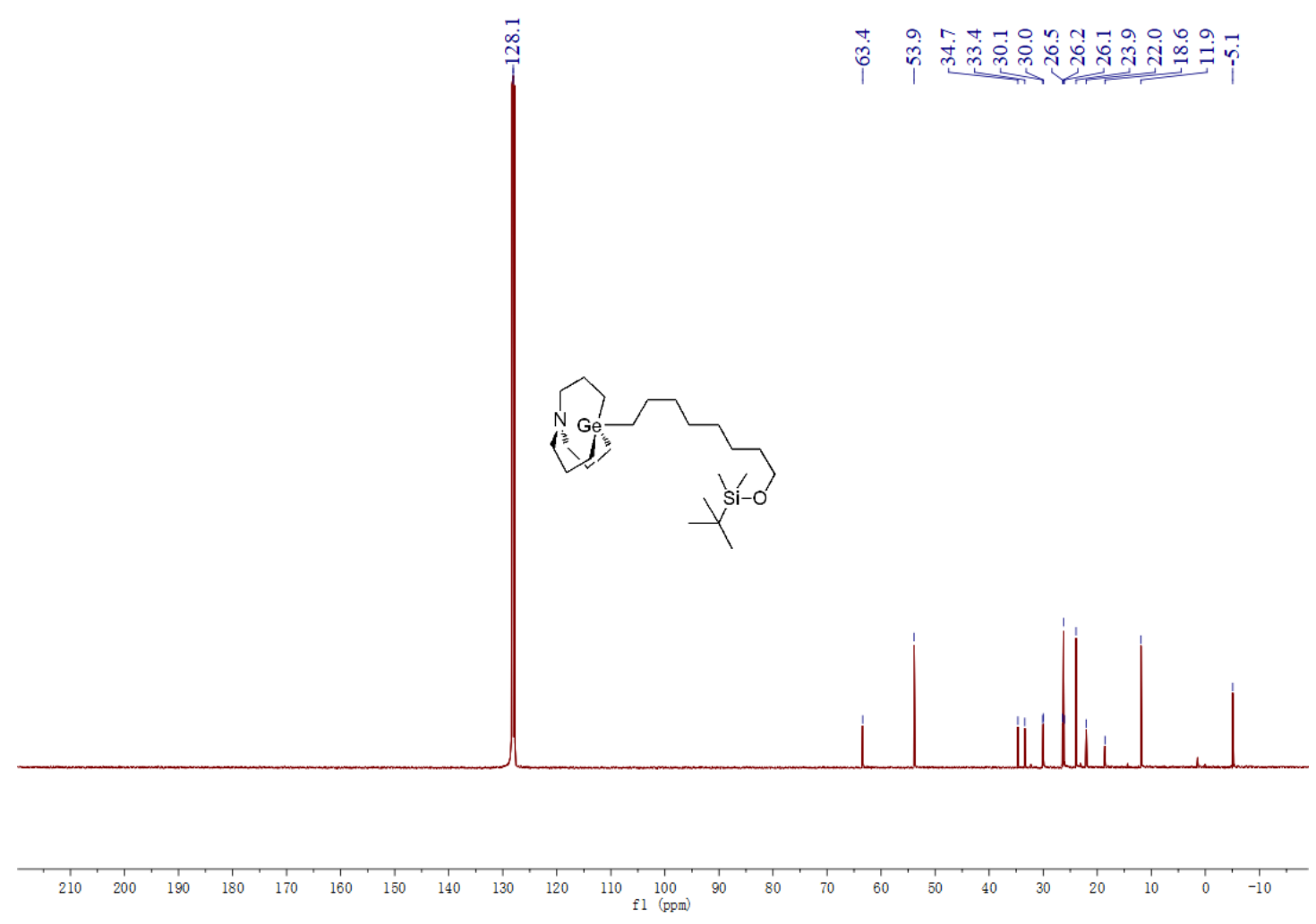

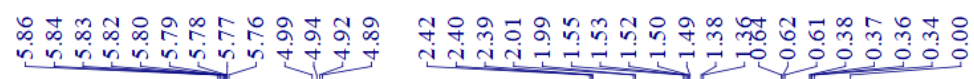

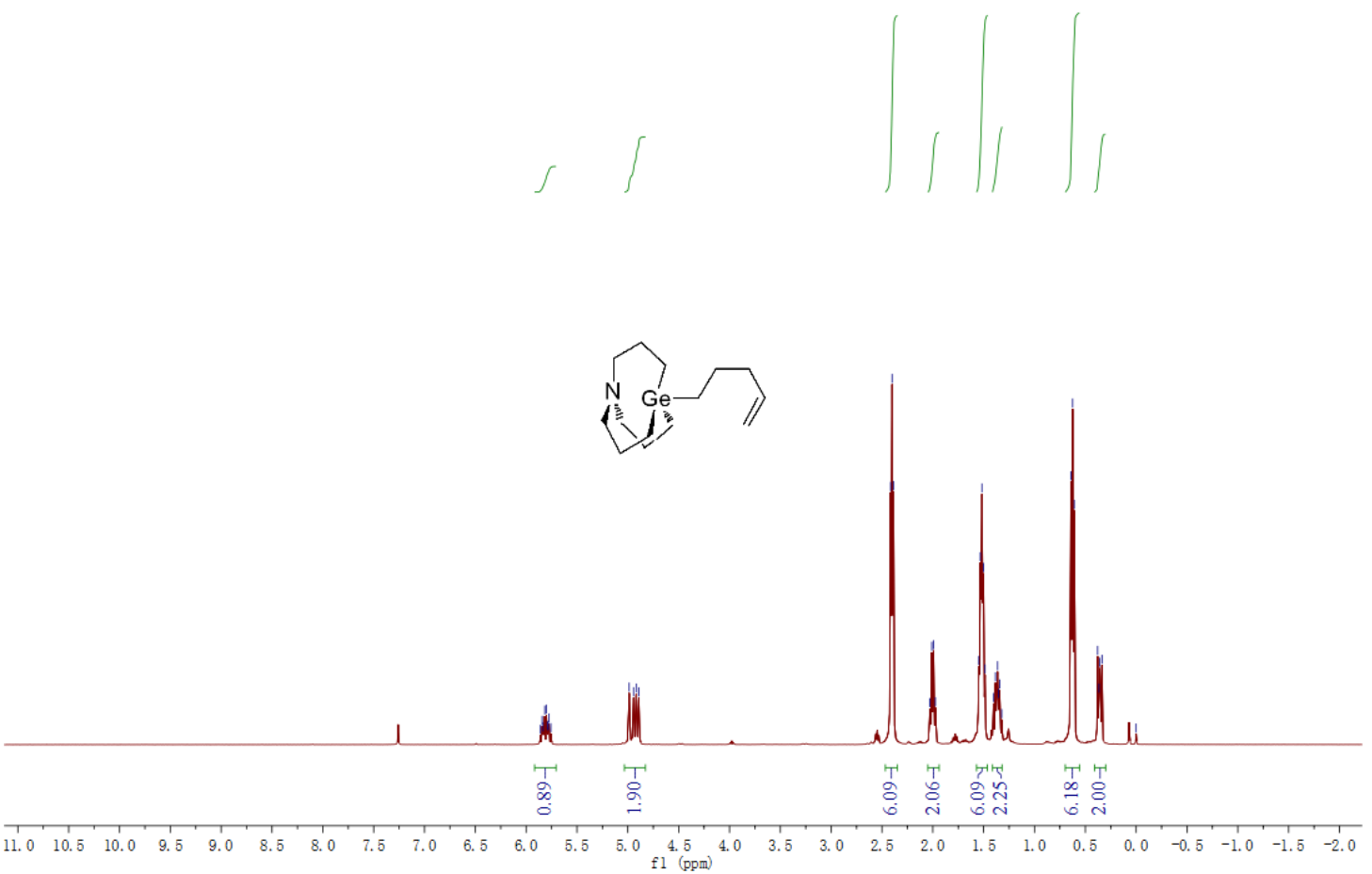




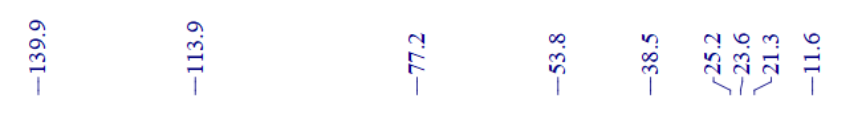

$\overbrace{\substack{N \\ \text { Ge }}}>$
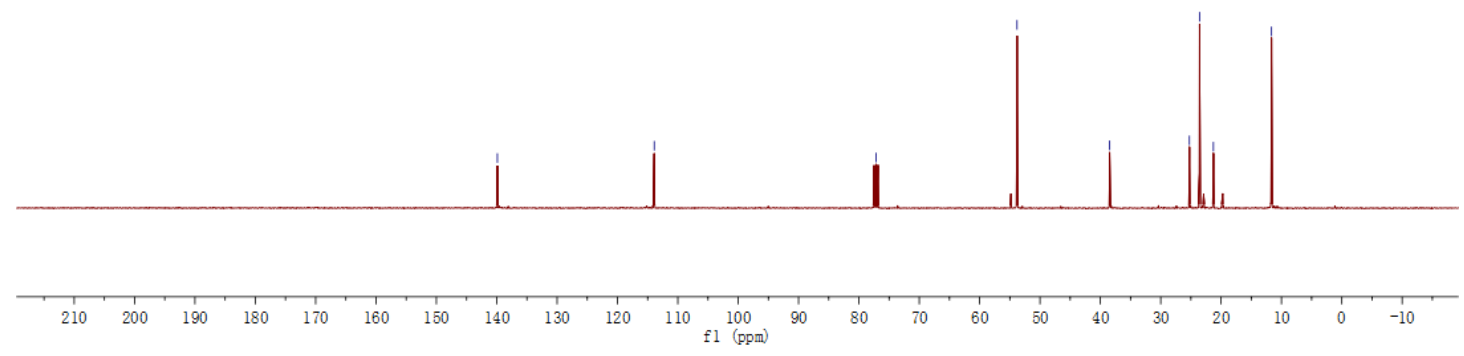

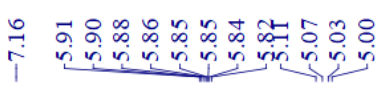

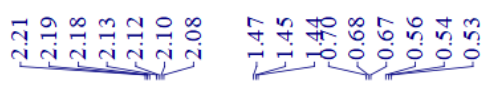

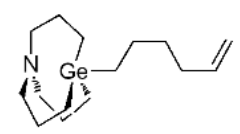

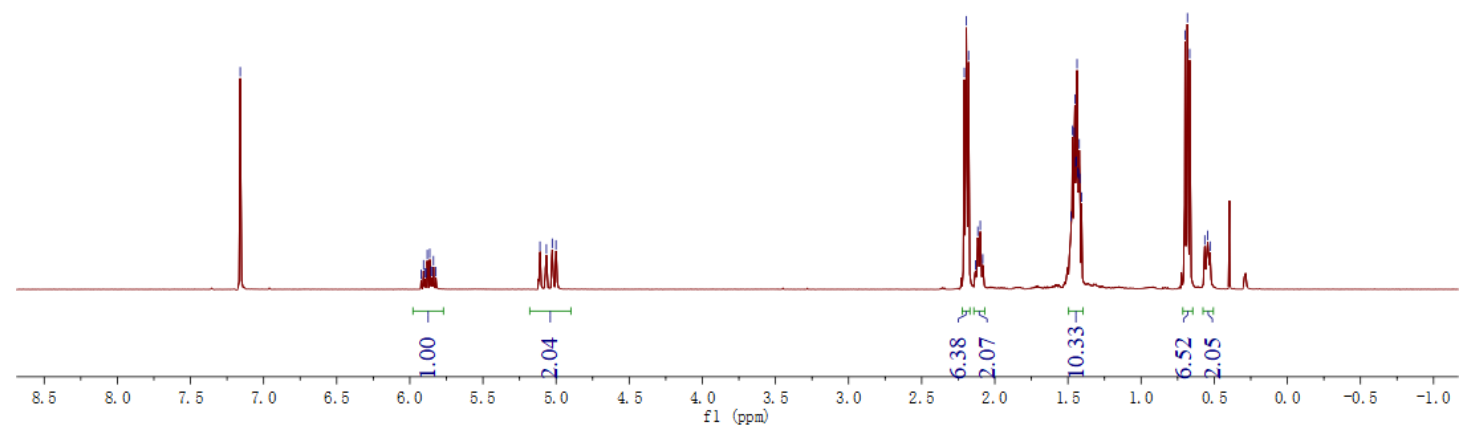



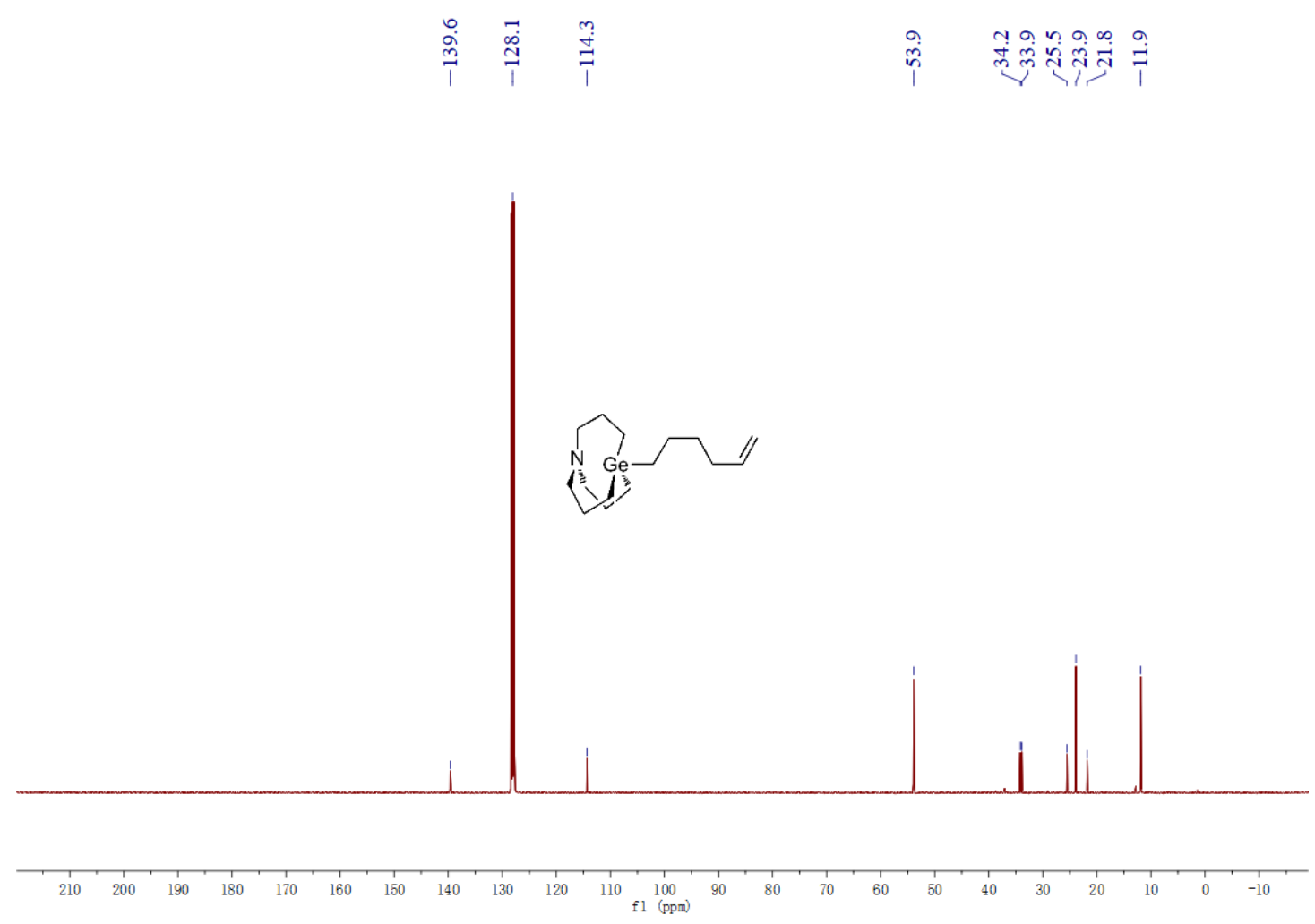

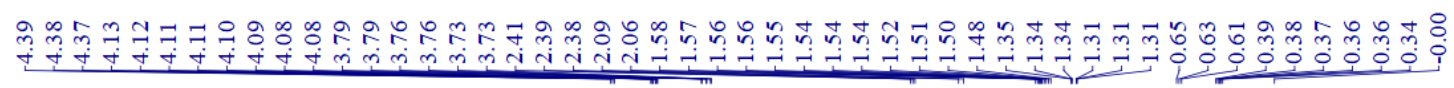
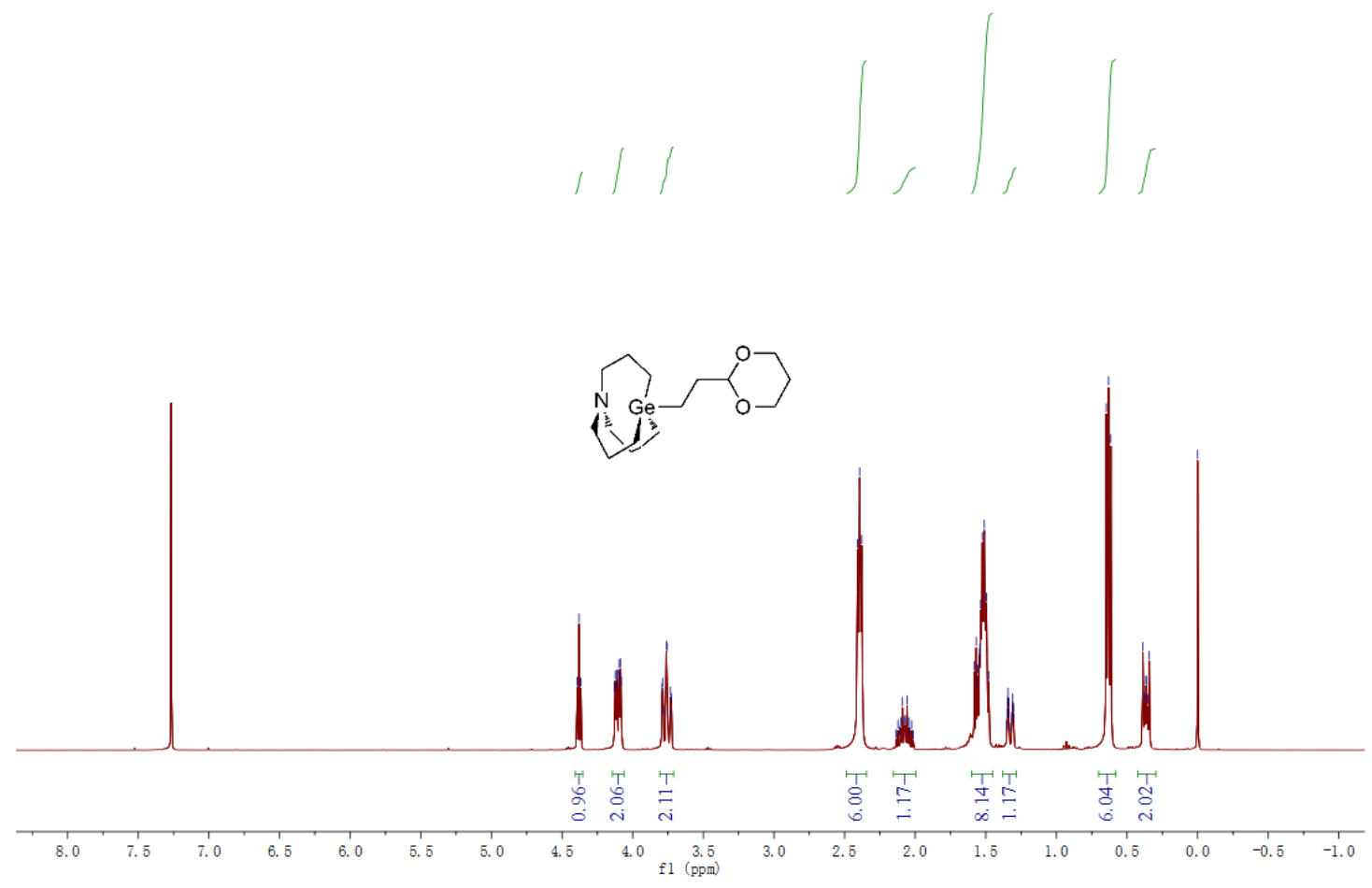


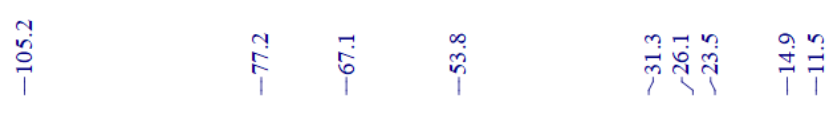

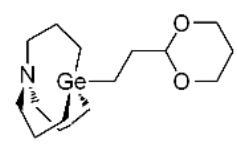
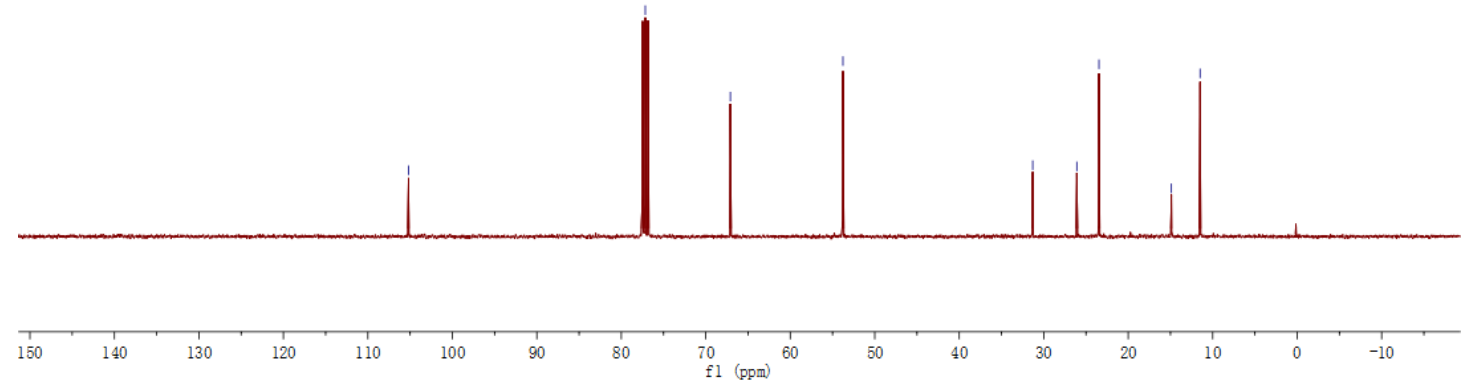

节

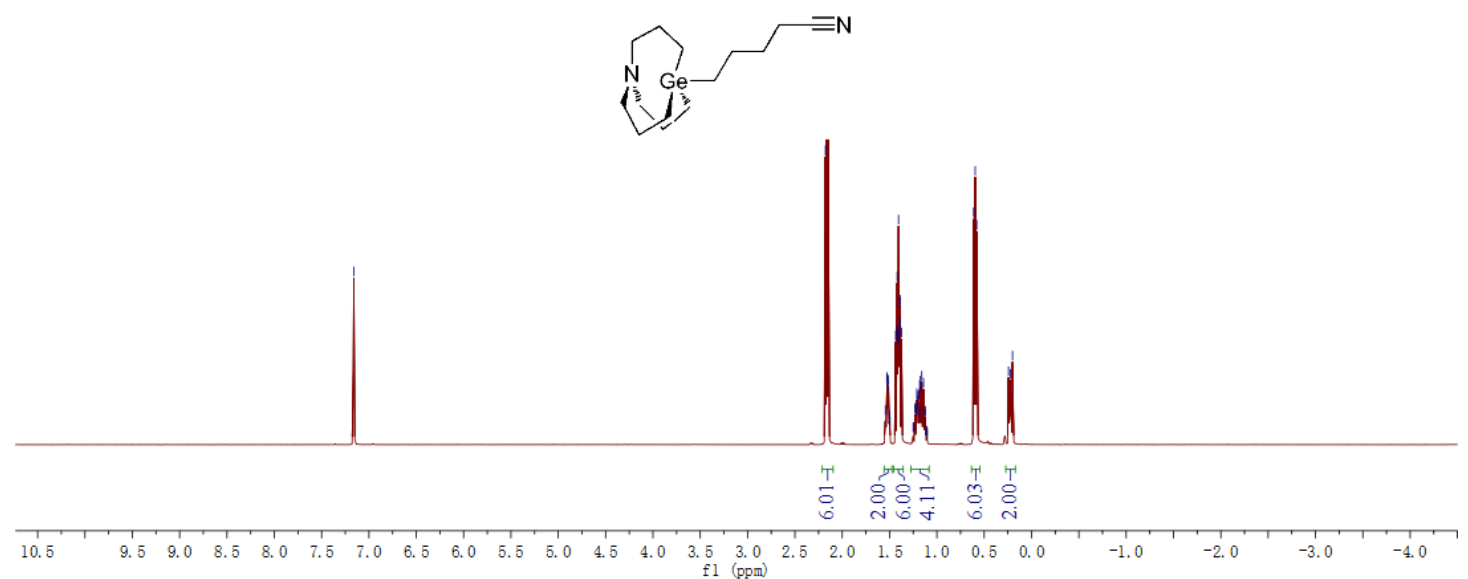



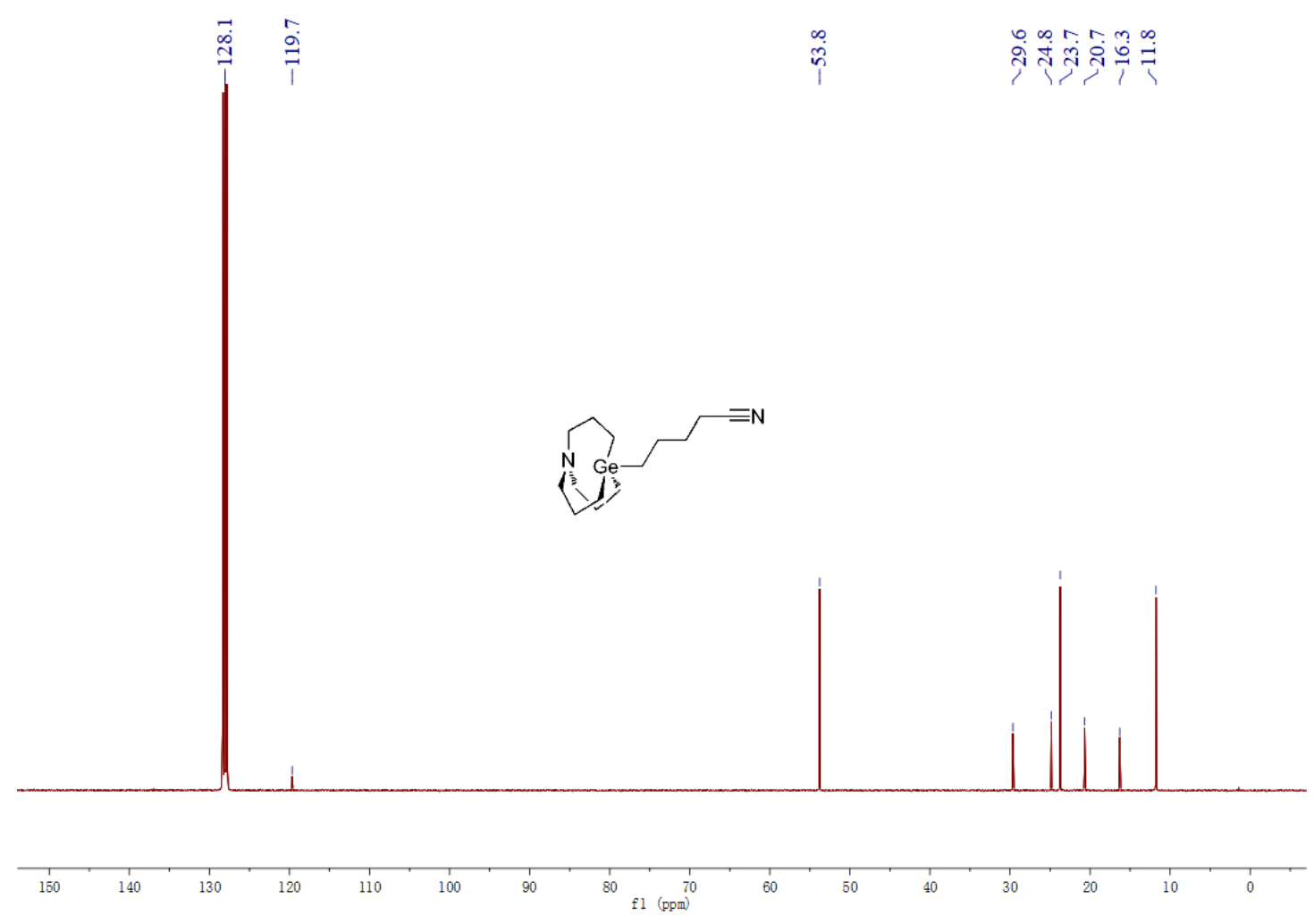

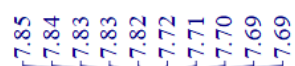

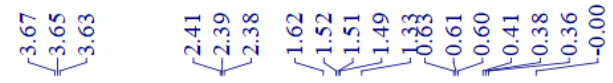

11
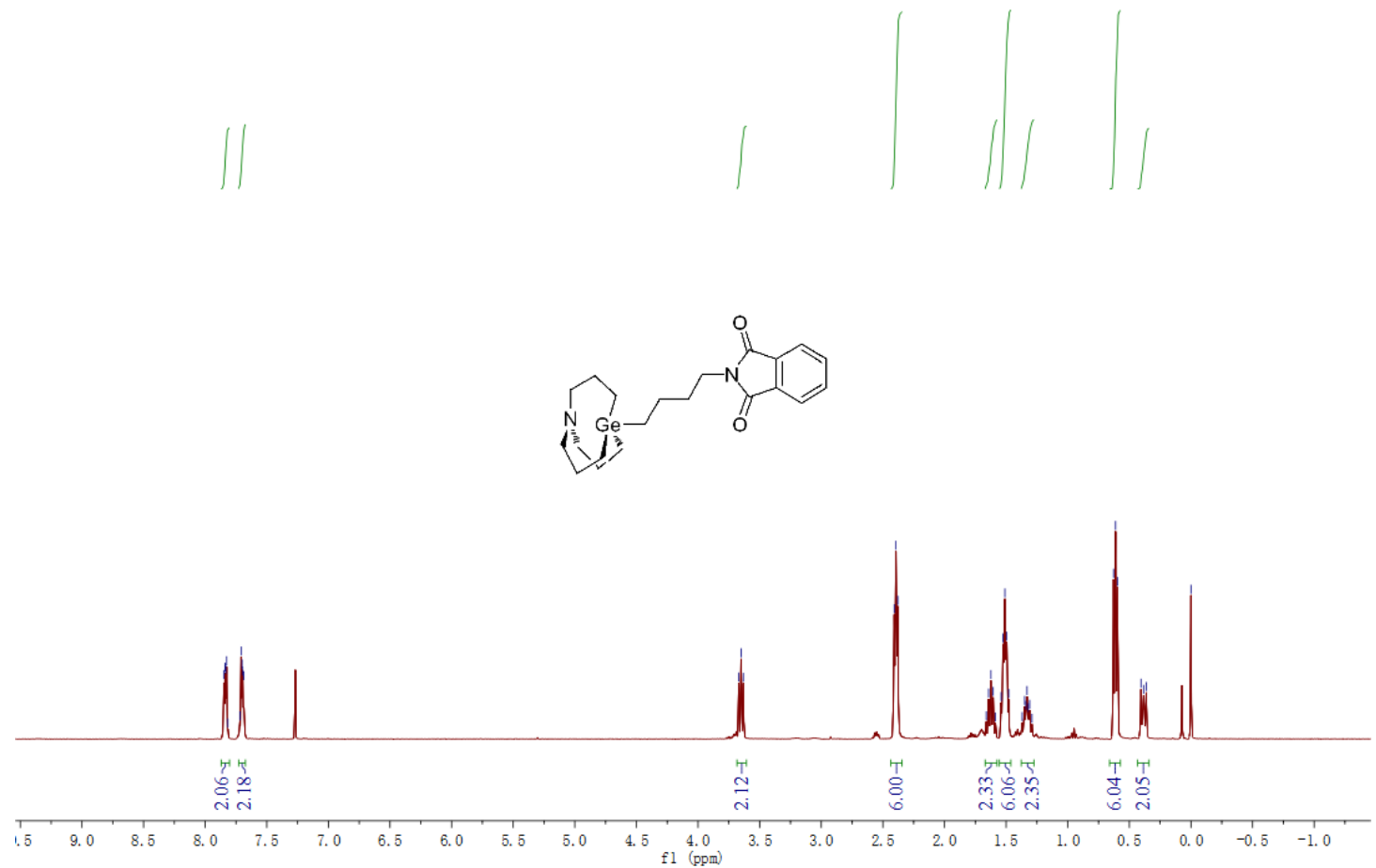


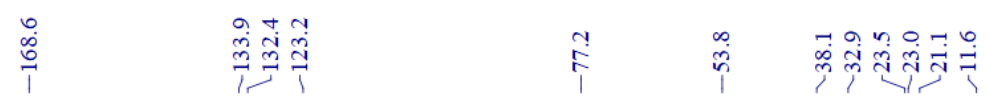
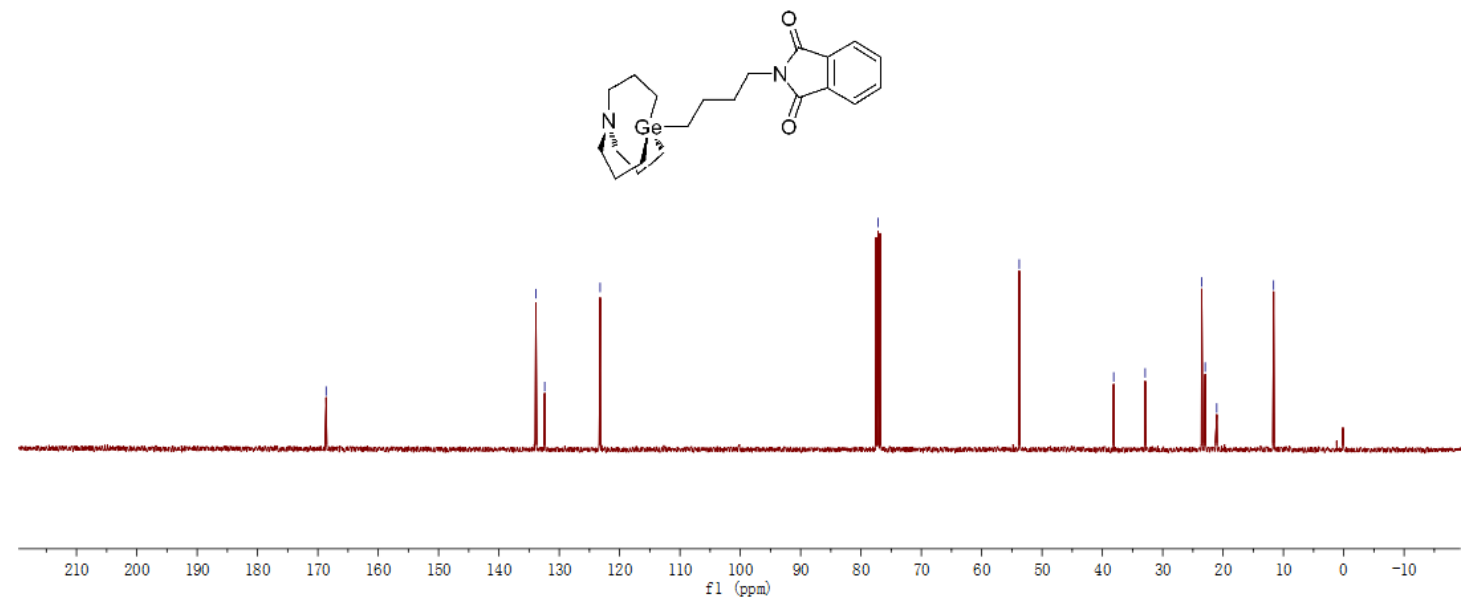

党

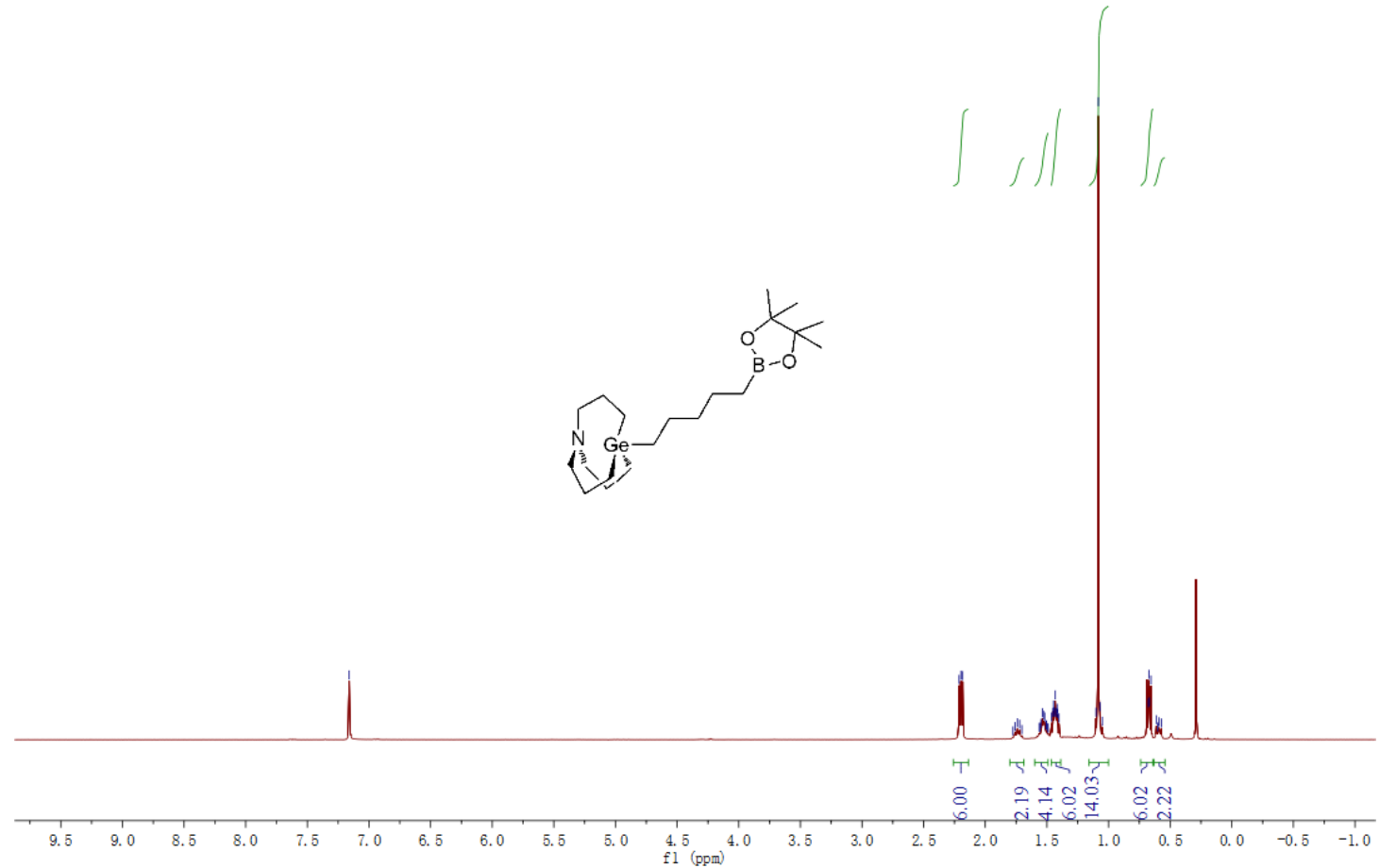



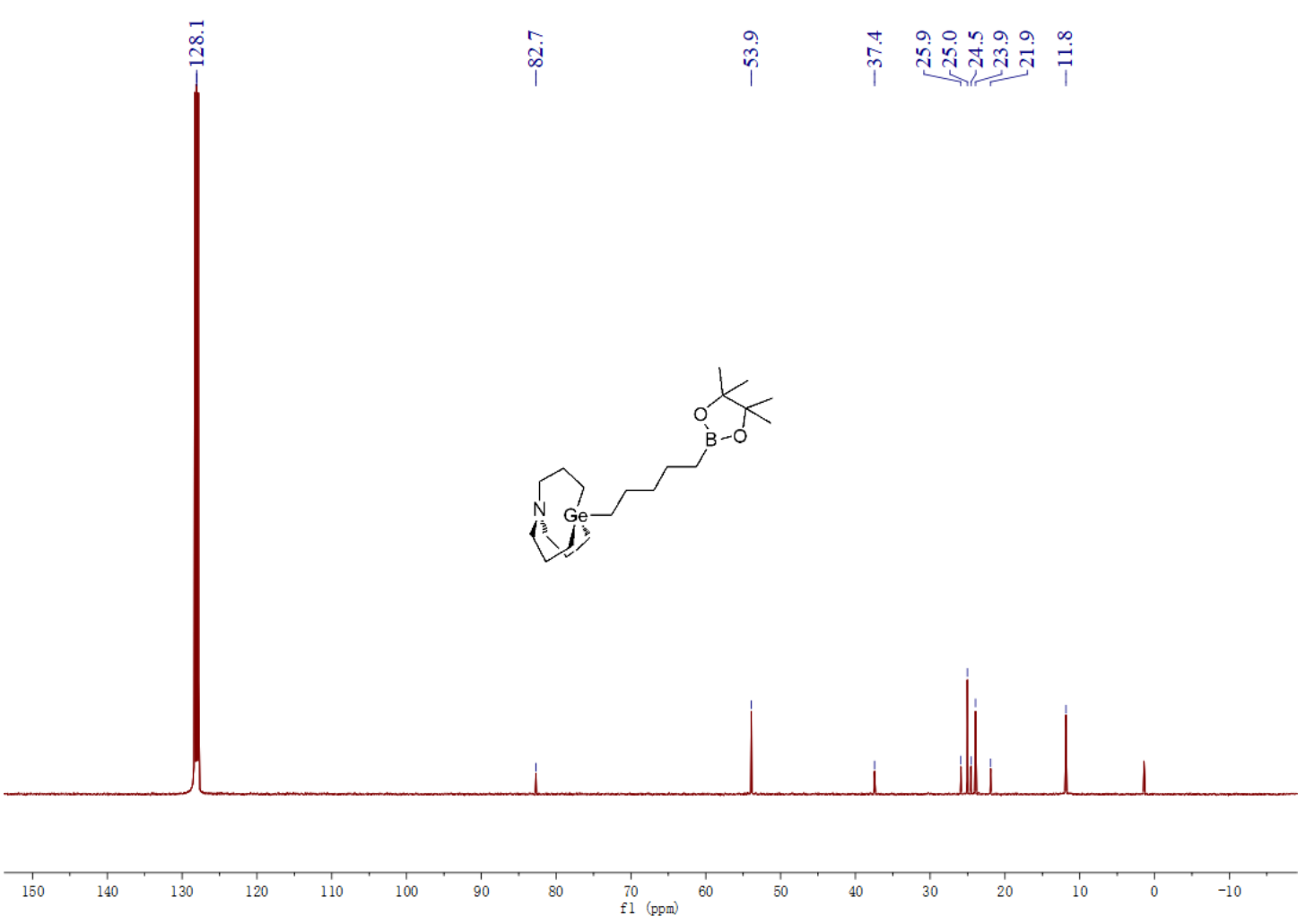

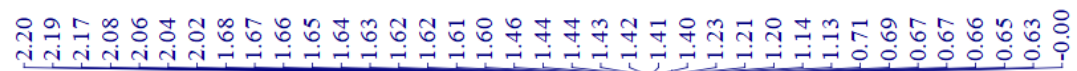

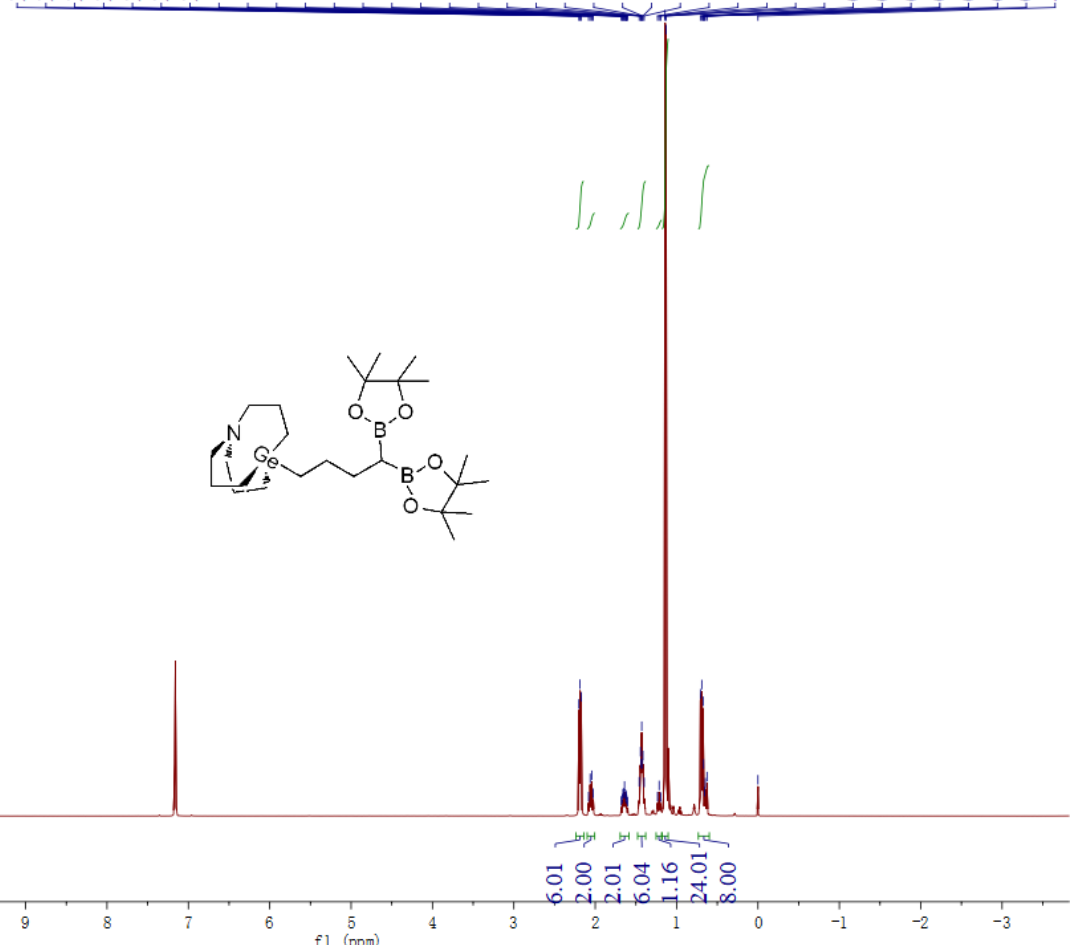



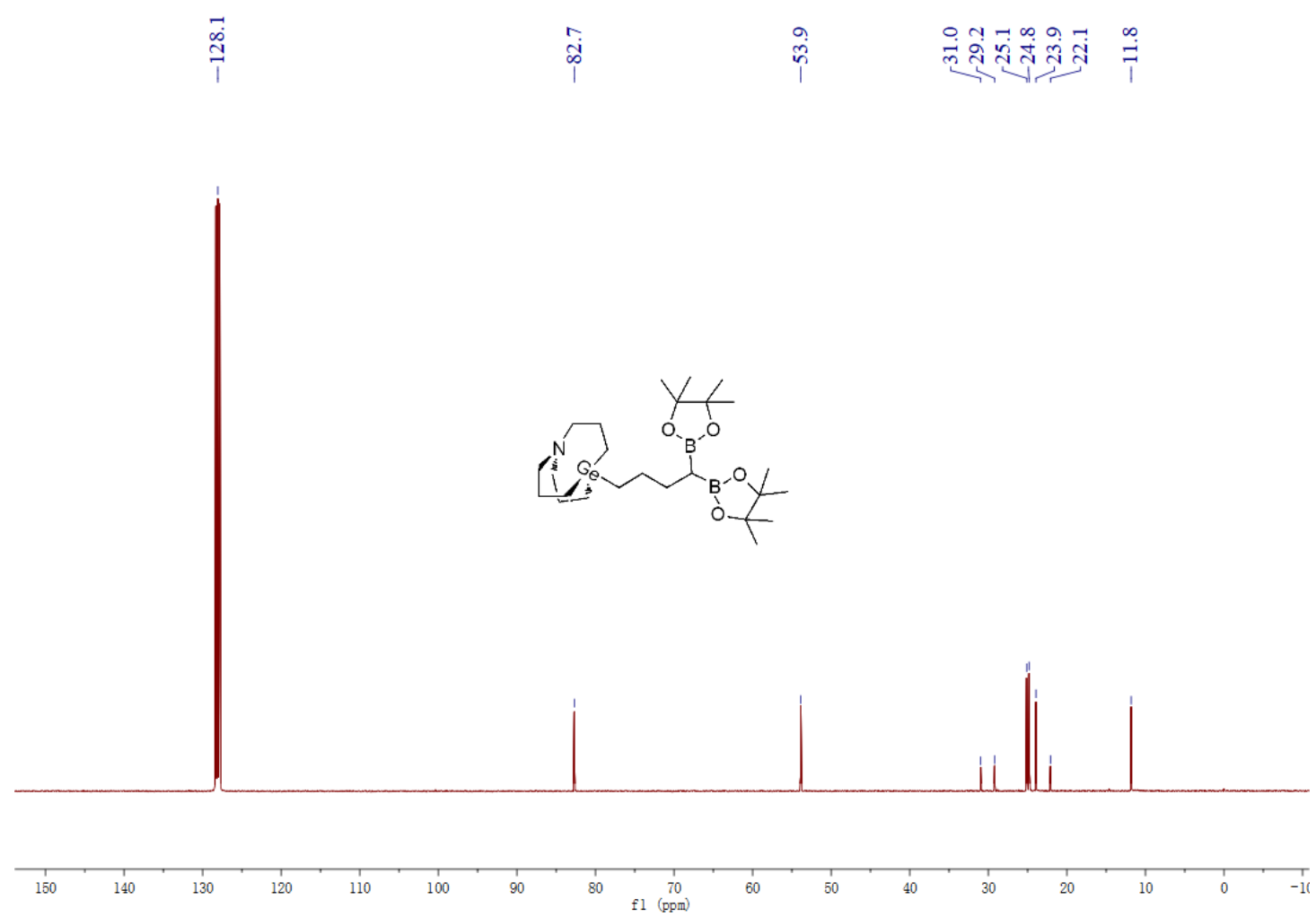

$\stackrel{\infty}{n}$

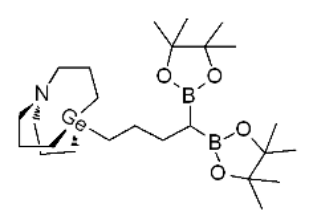

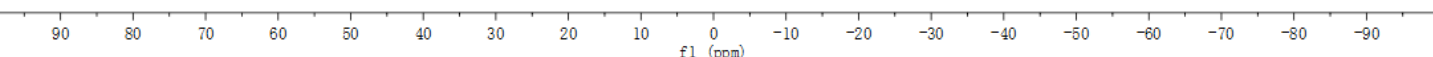




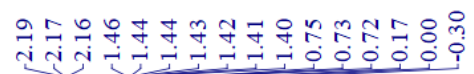
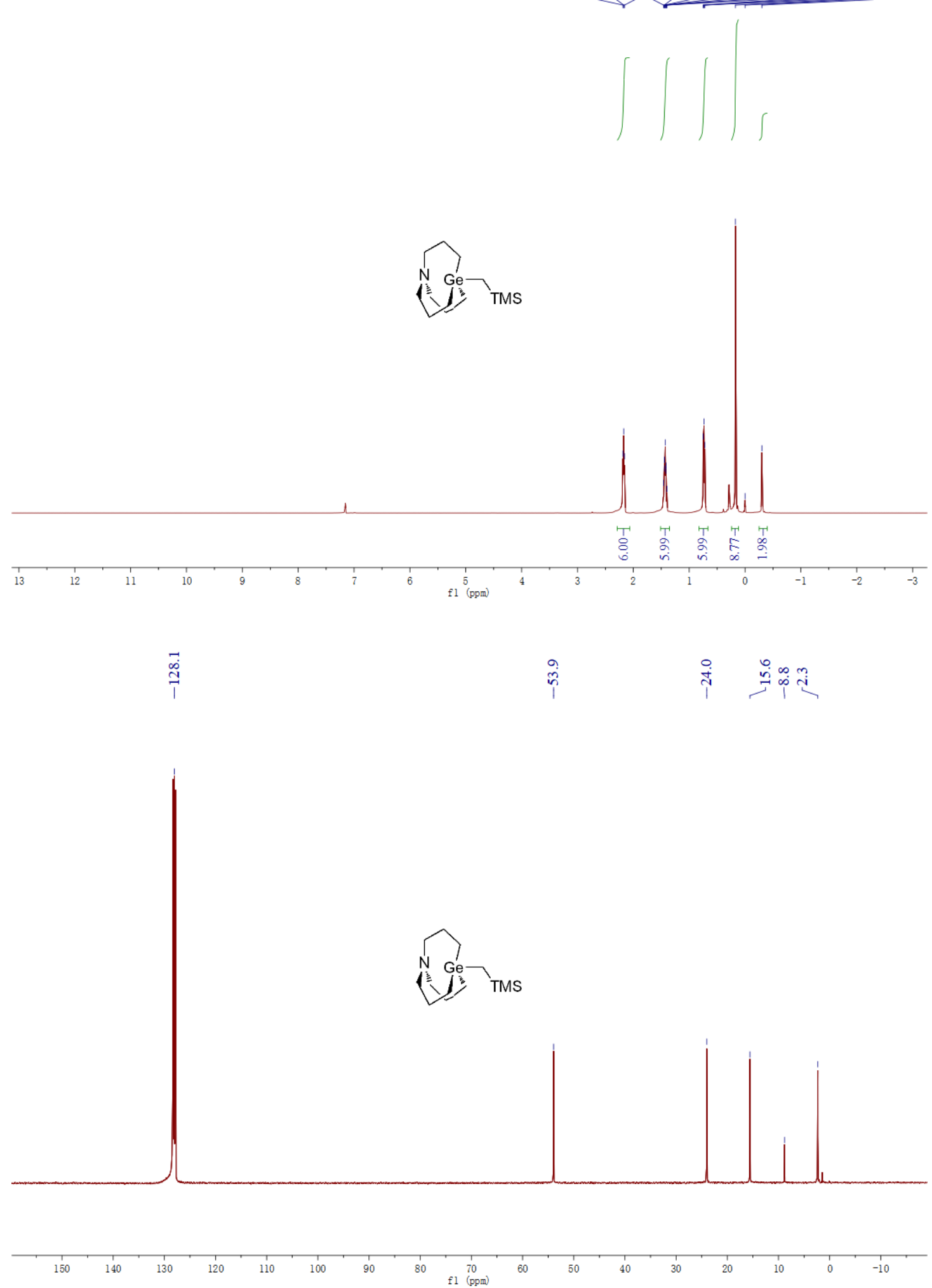


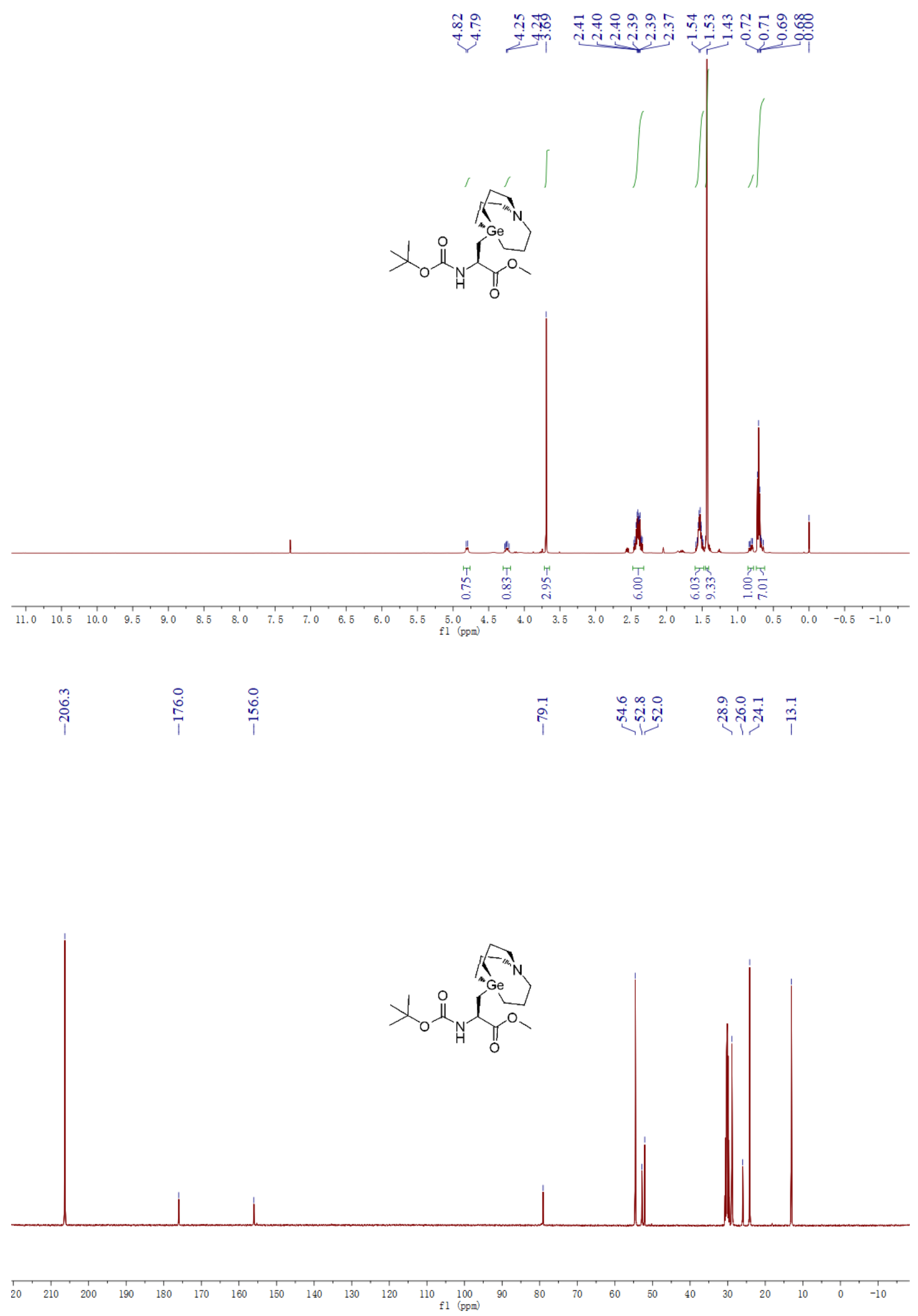




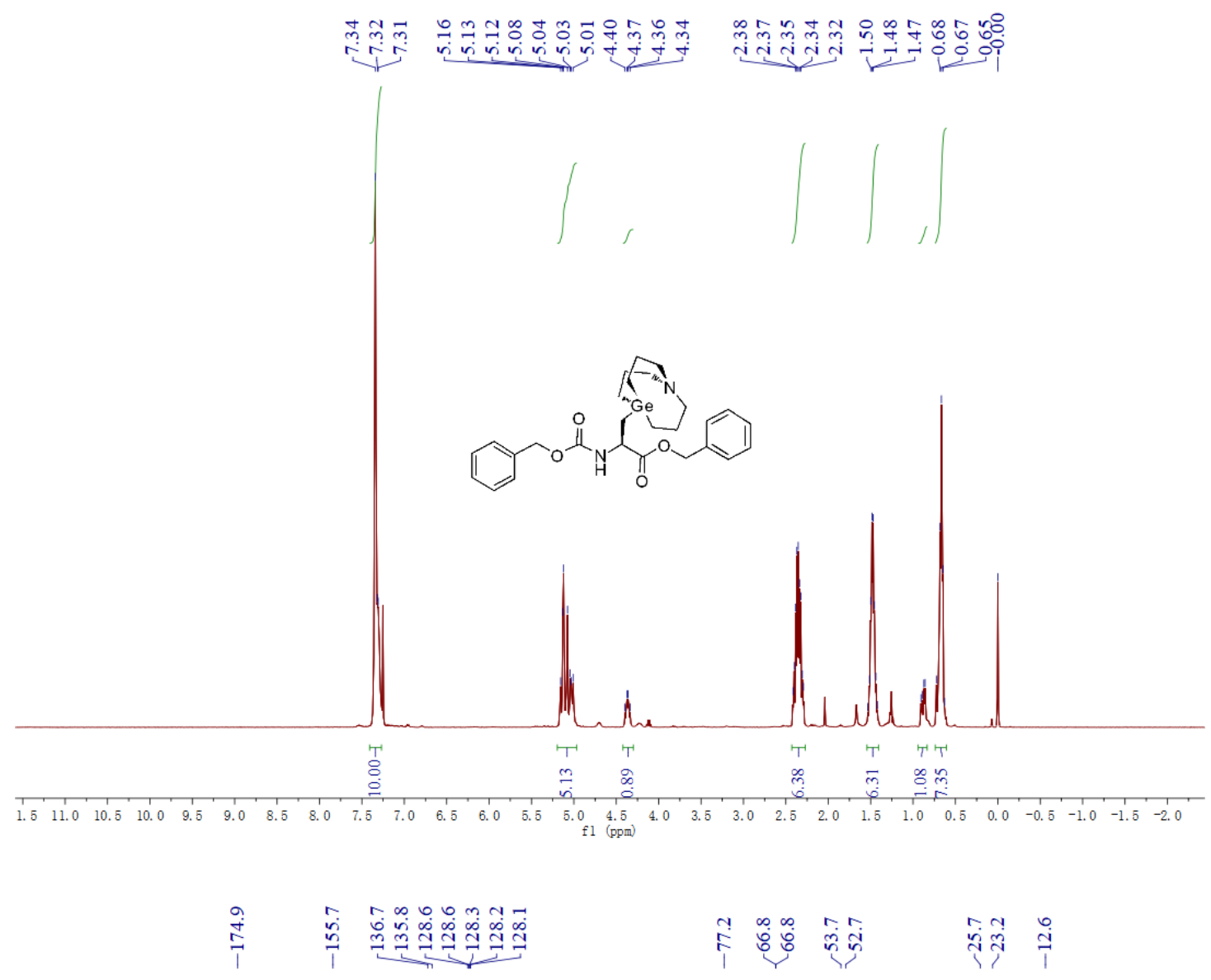

iction

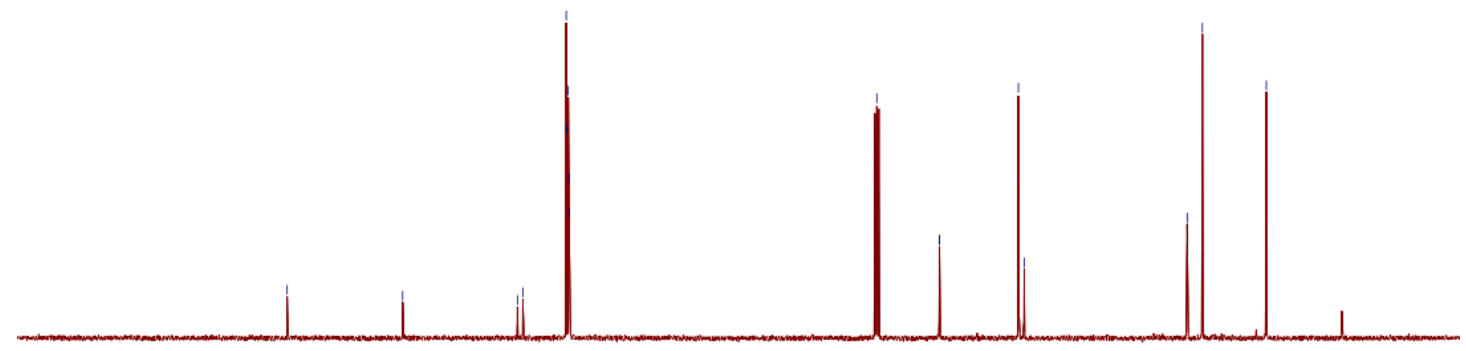

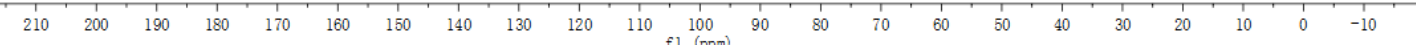




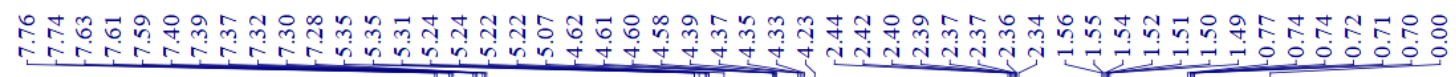
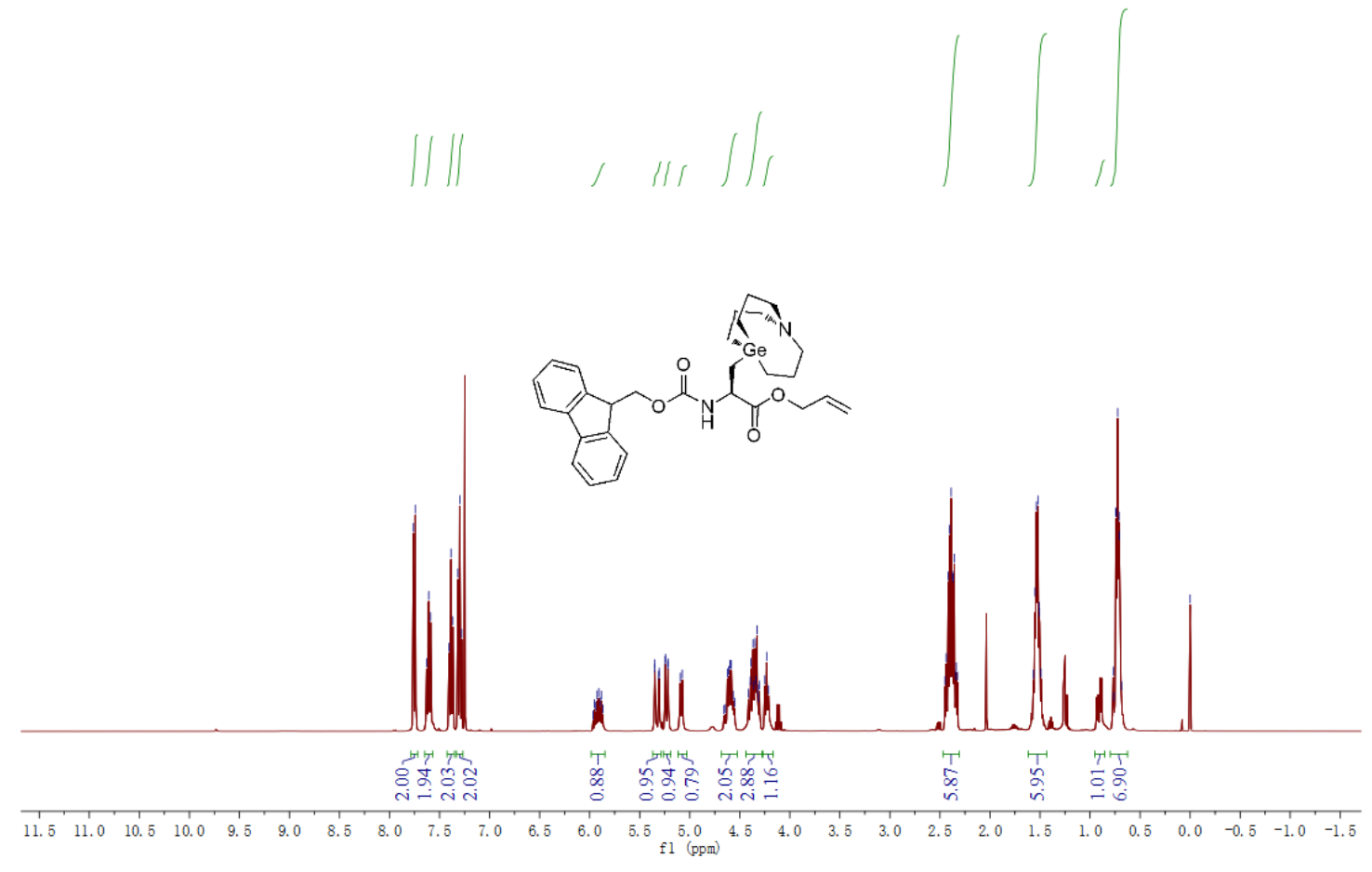

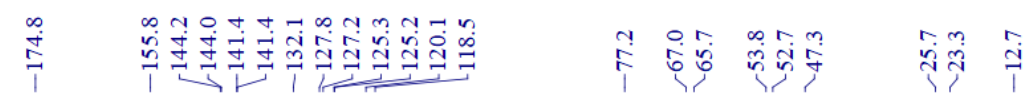

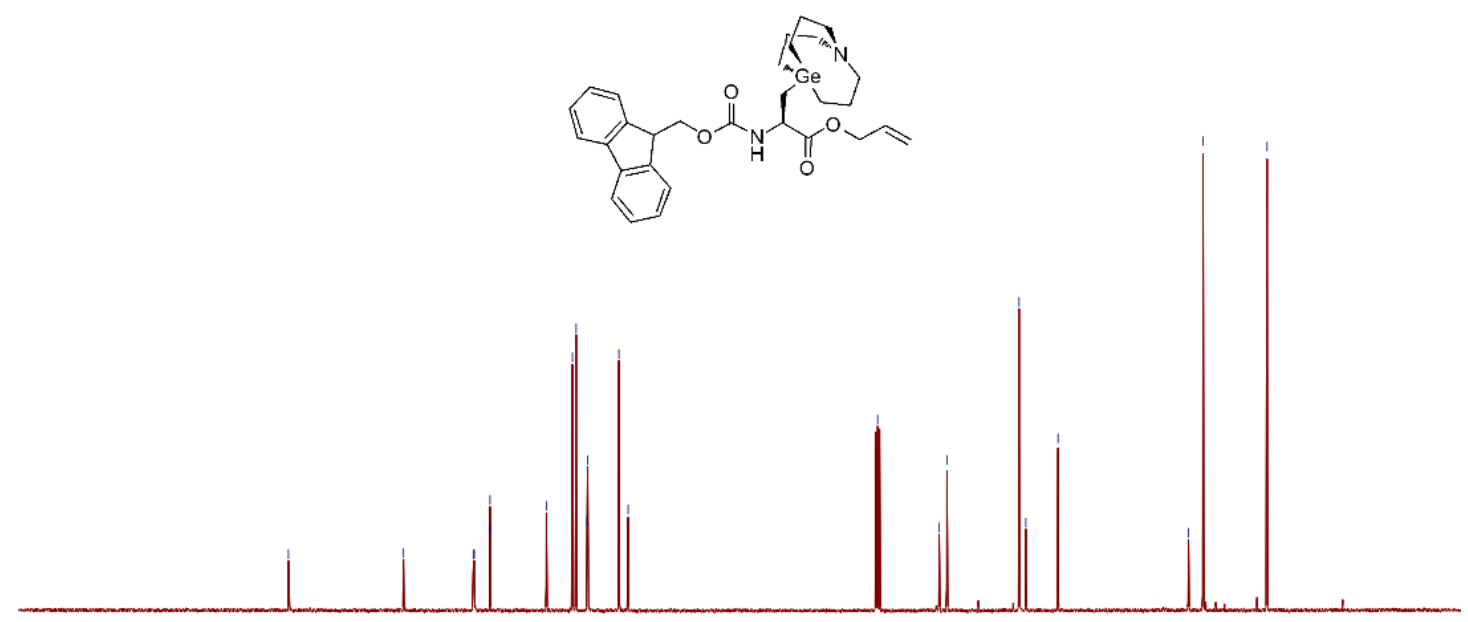

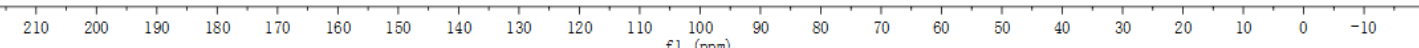




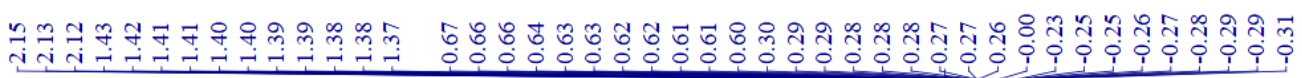
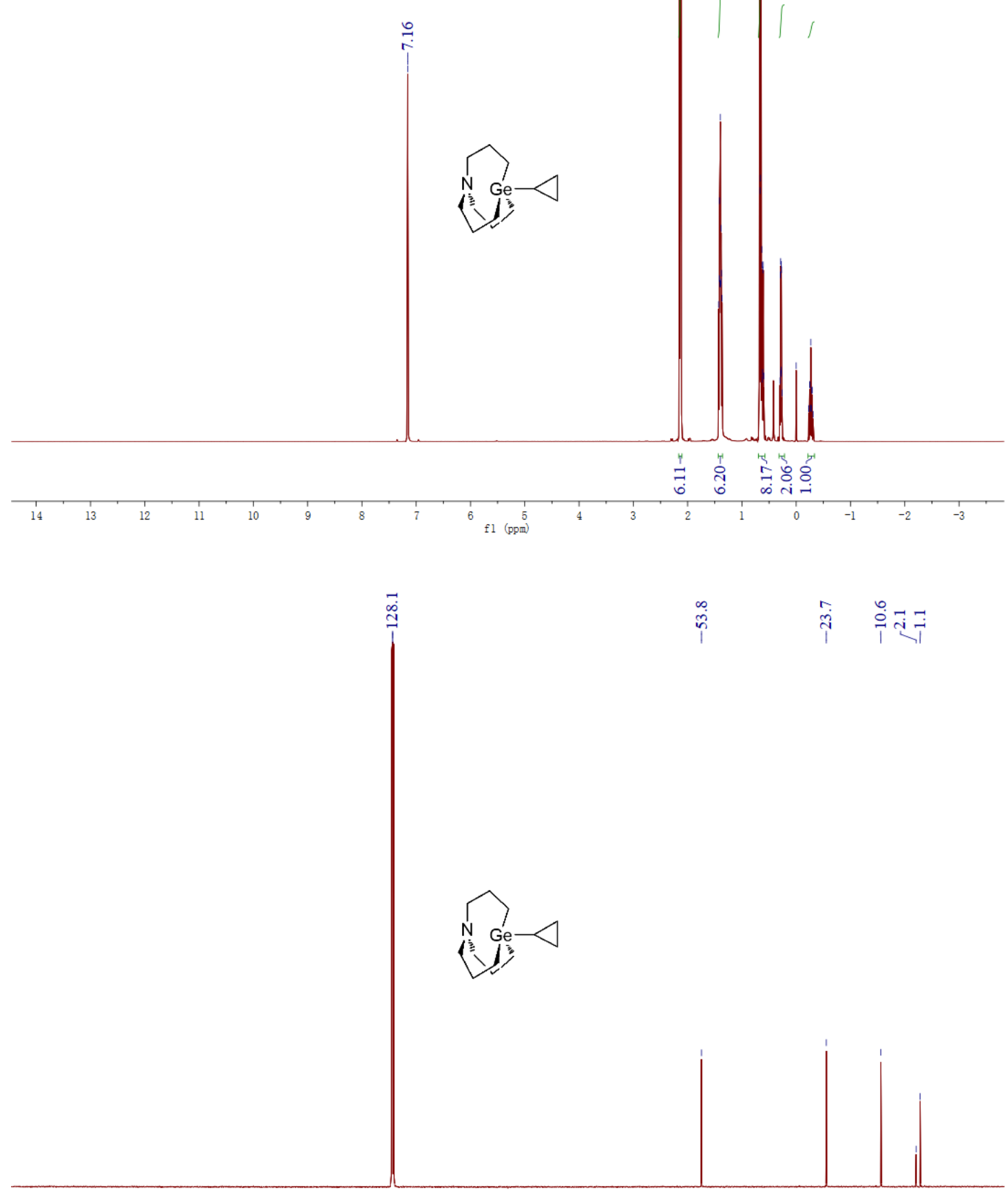

$\begin{array}{llllllllllllllllllllllllllllllllll}1 & 1 \\ 210 & 200 & 190 & 180 & 170 & 160 & 150 & 140 & 130 & 120 & 110 & 100 & 90 & 80 & 70 & 60 & 50 & 40 & 30 & 20 & 10 & 0 & -10\end{array}$ 


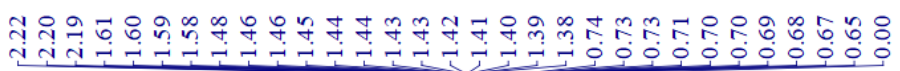
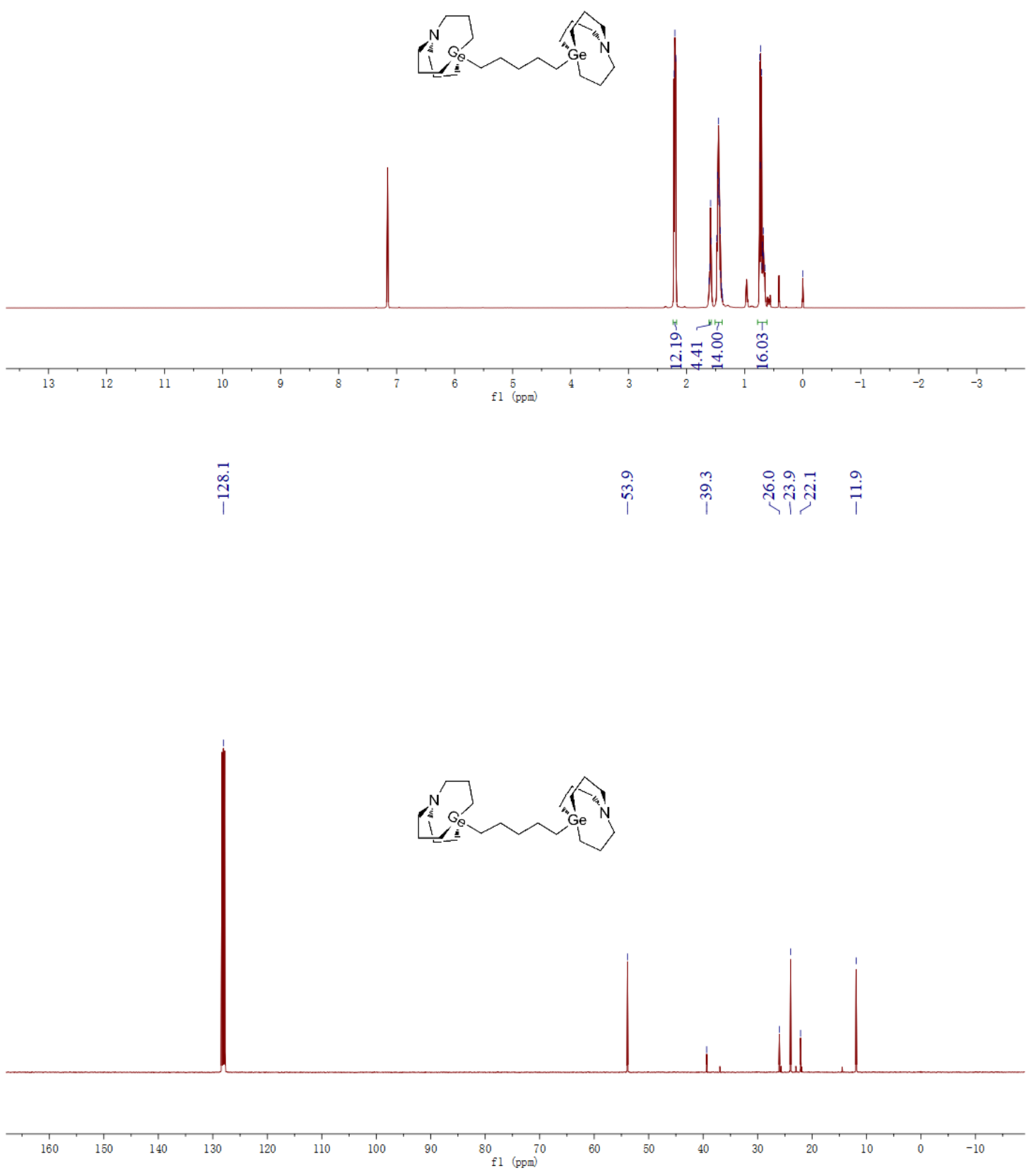

S80 


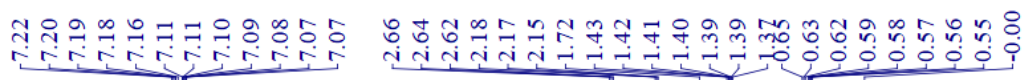

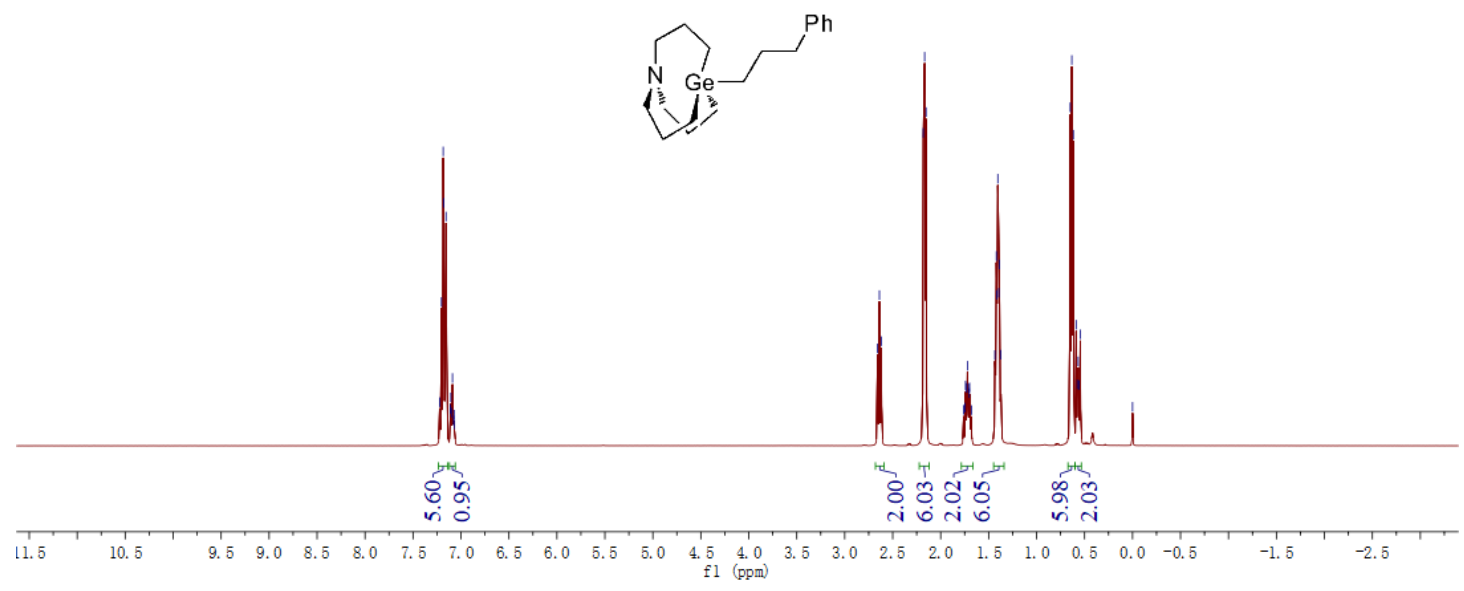

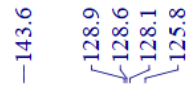

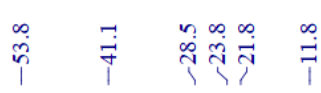

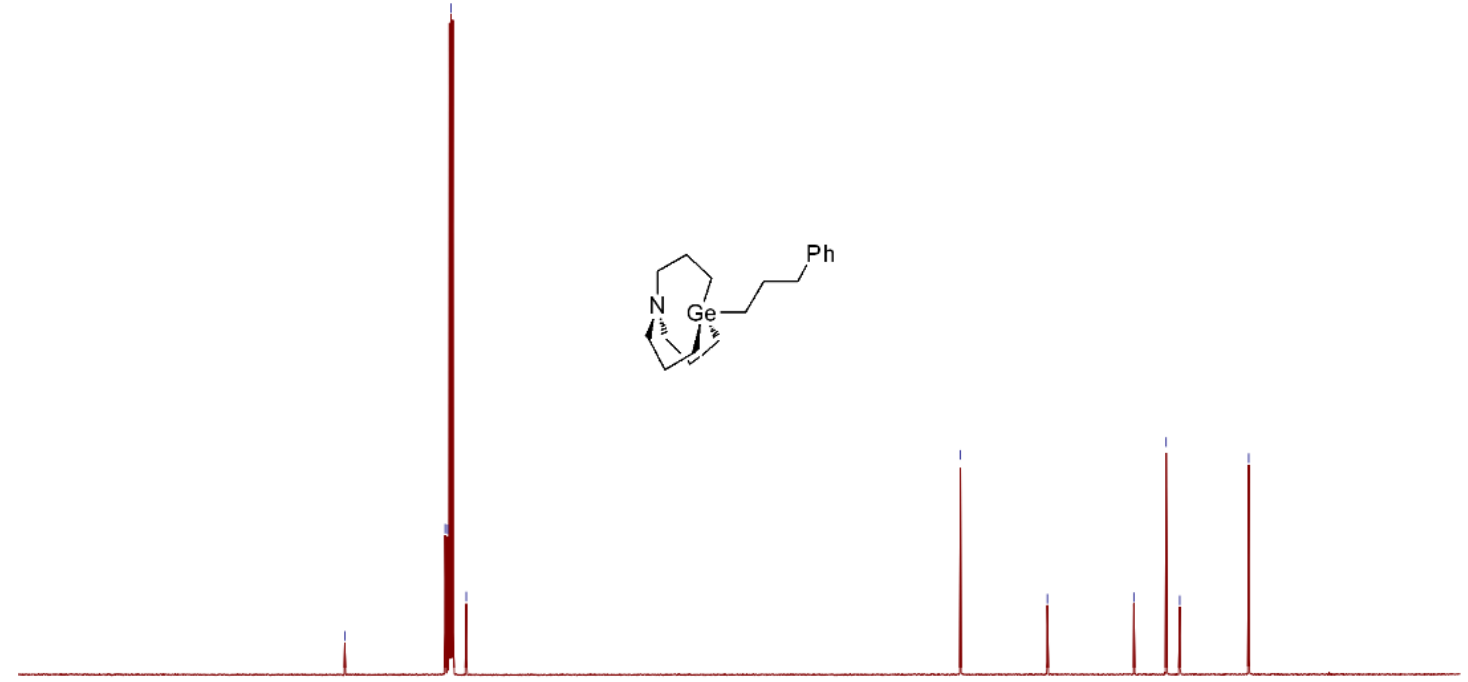

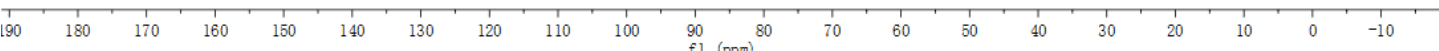




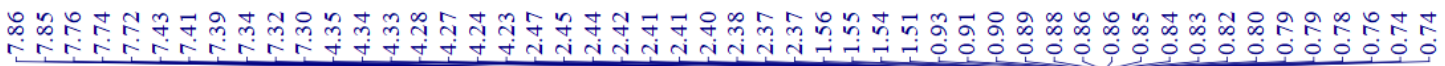
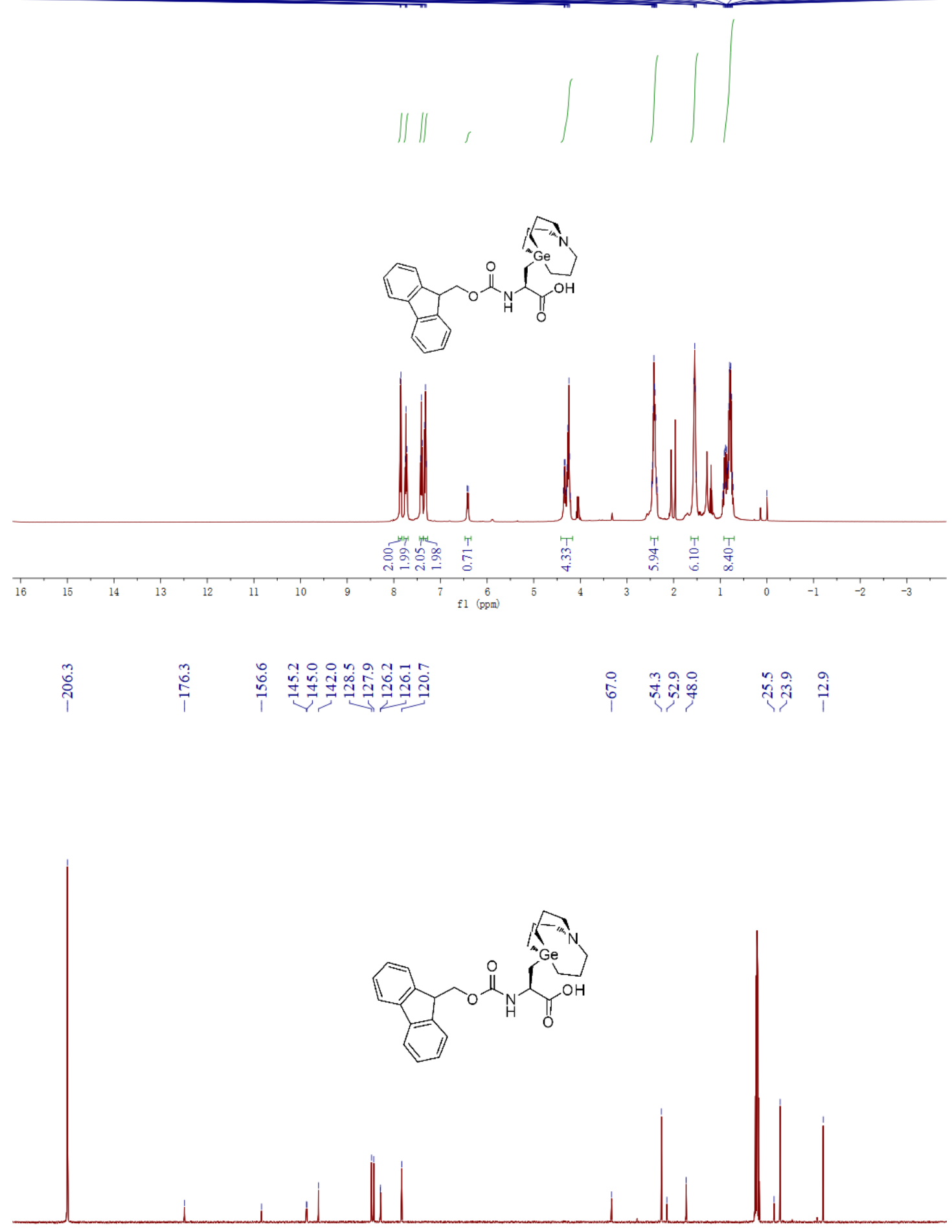

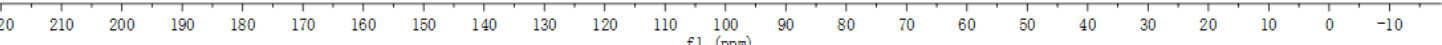



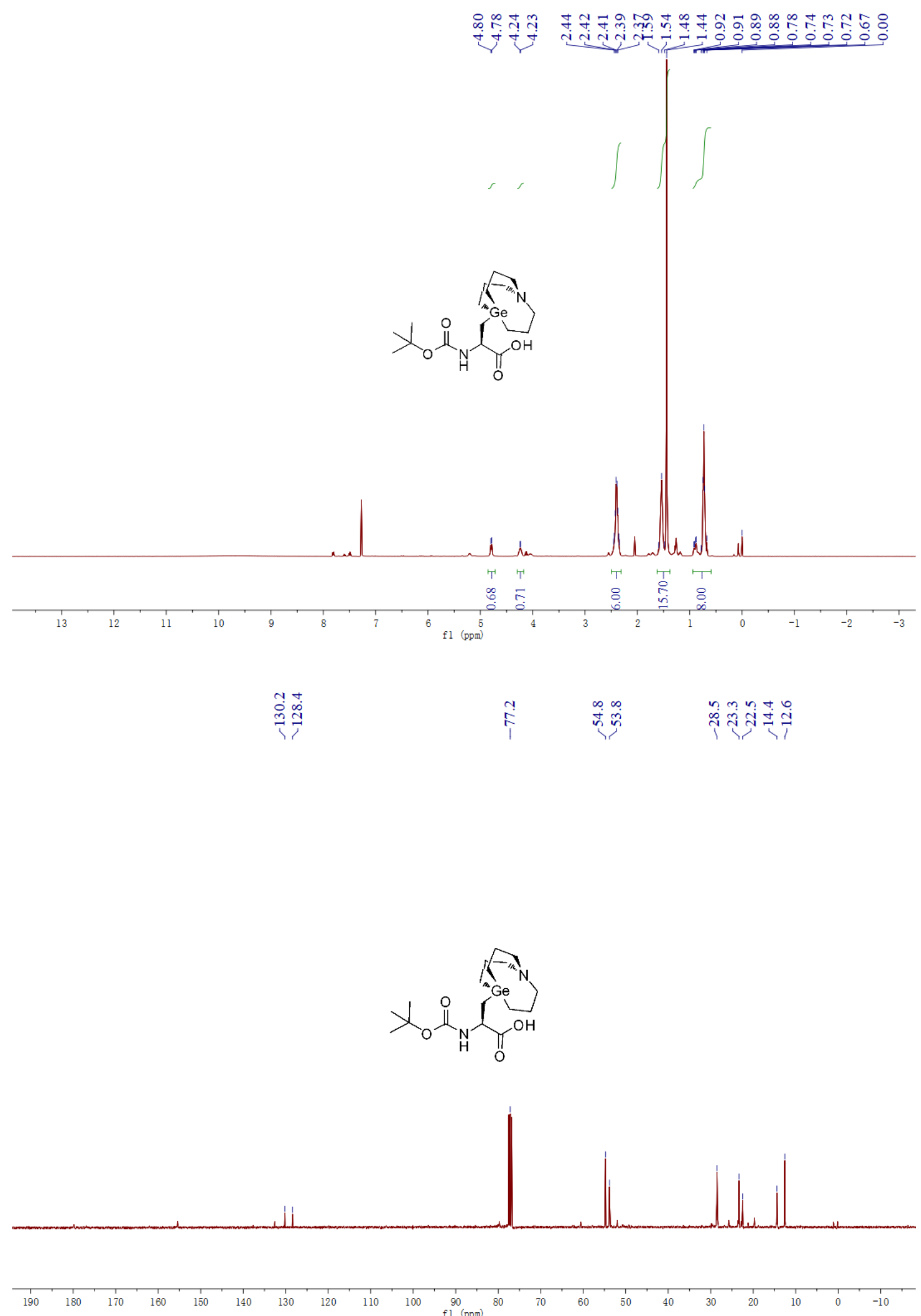


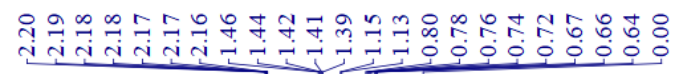
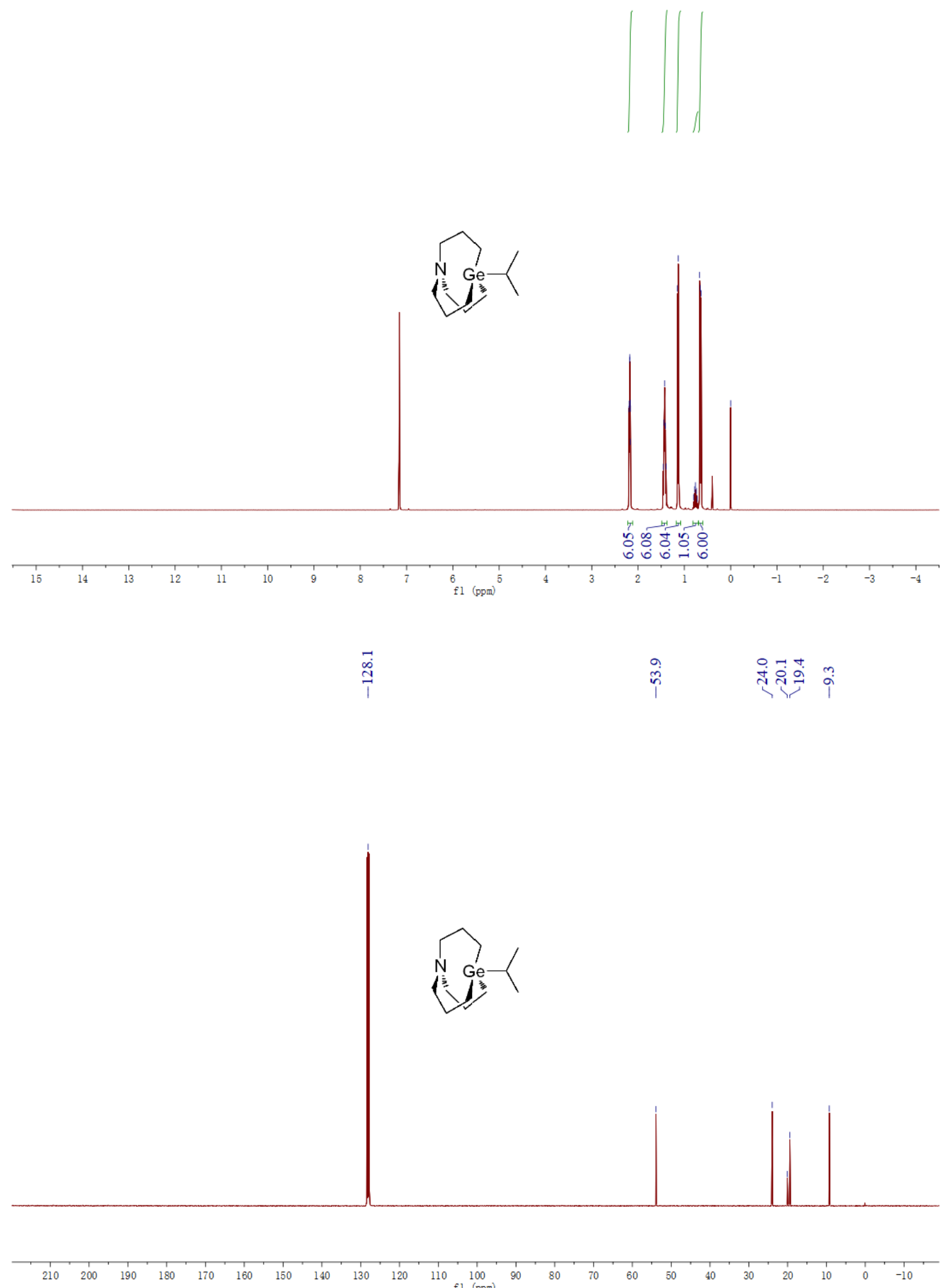


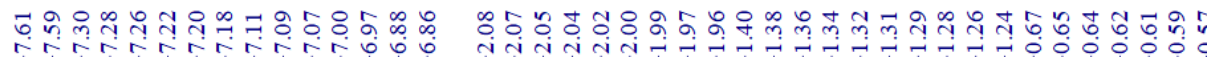
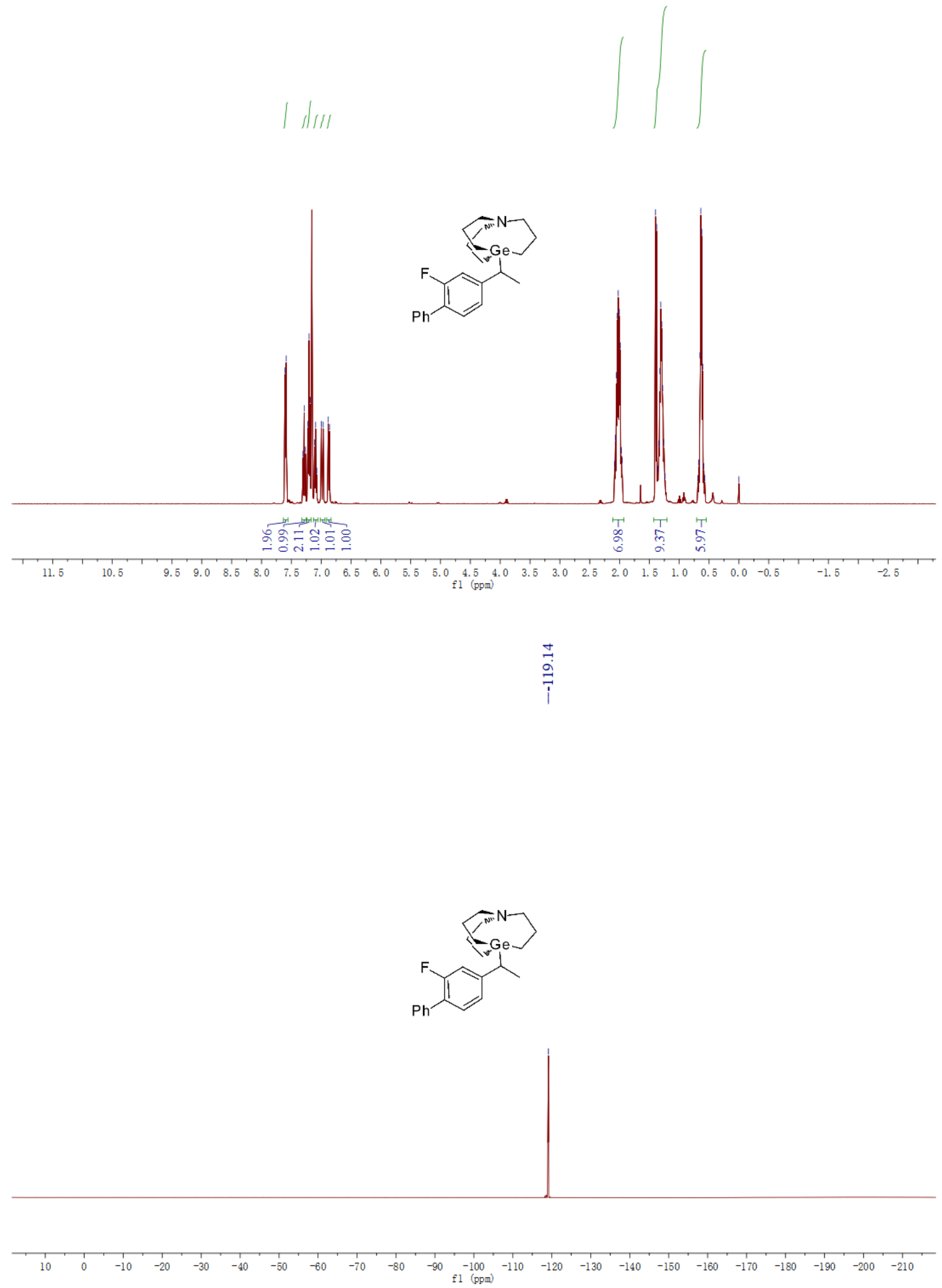


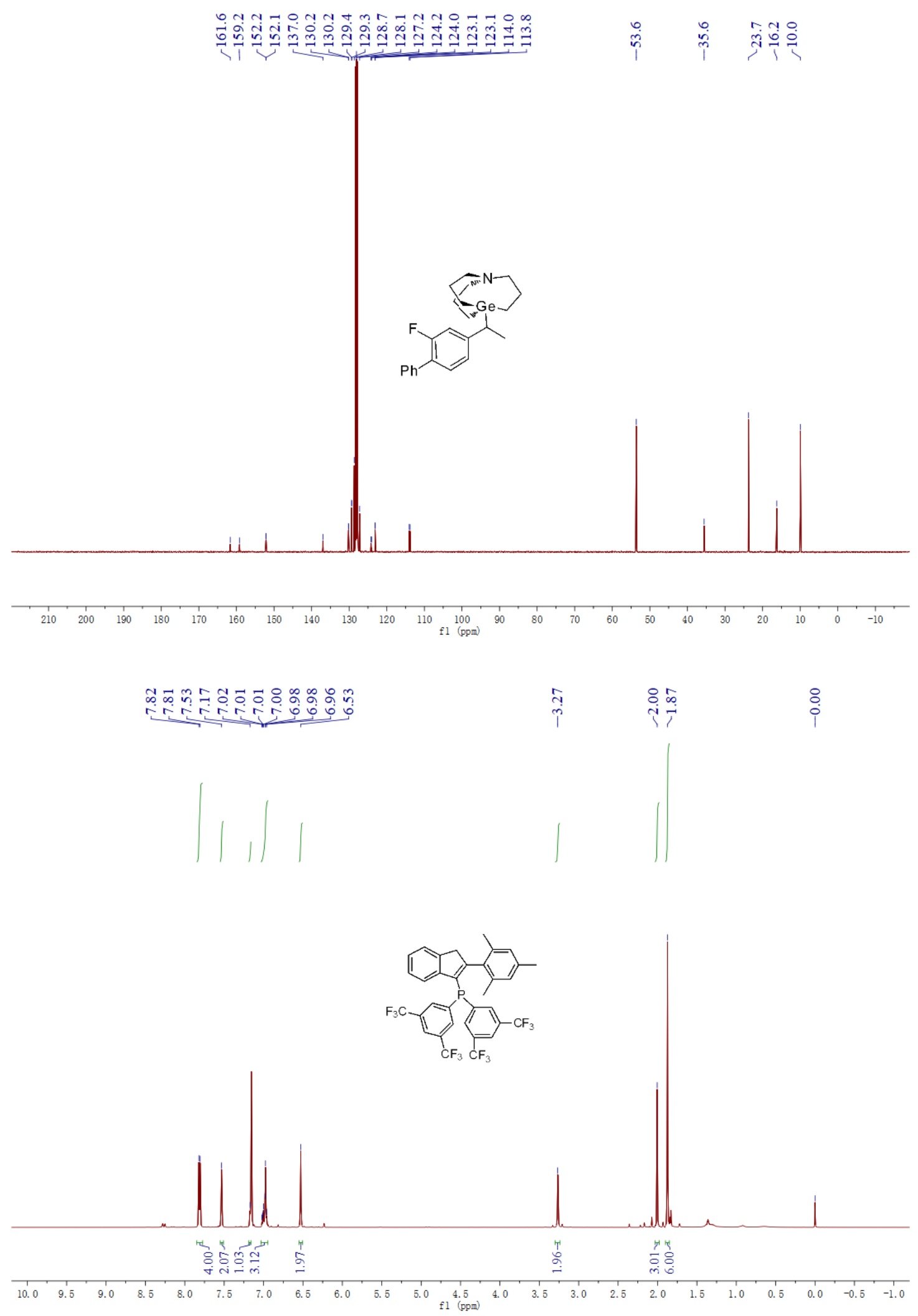


8
ஸे
1

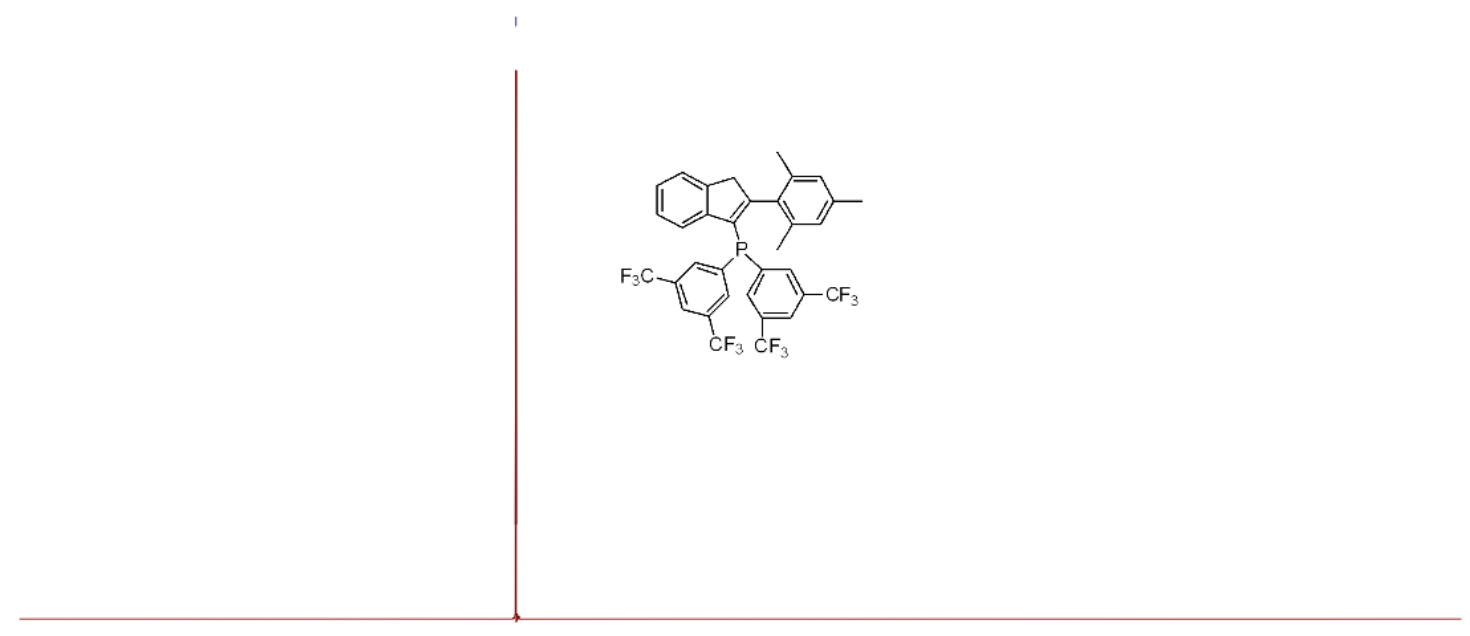

\begin{tabular}{rlllllllllllllllllllllllllll}
\hline 10 & 1 & -10 & -20 & -30 & -40 & -50 & -60 & -70 & -80 & -90 & -100 & -110 & -120 & -130 & -140 & -150 & -160 & -170 & -180 & -190 & -100 & -210 & 1
\end{tabular}

$\frac{a}{i}$

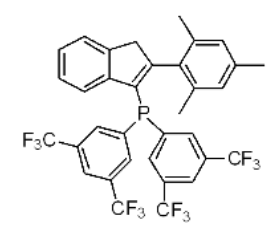

$\begin{array}{rllllllllllllllllllllllllllll}130 & 110 & 90 & 80 & 70 & 60 & 50 & 40 & 30 & 20 & 10 & 0 & -10 & -30 & -50 & -70 & -90 & -110 & -130 & -150 & -170 & -190 & -210 & -230 & 1 & 1\end{array}$

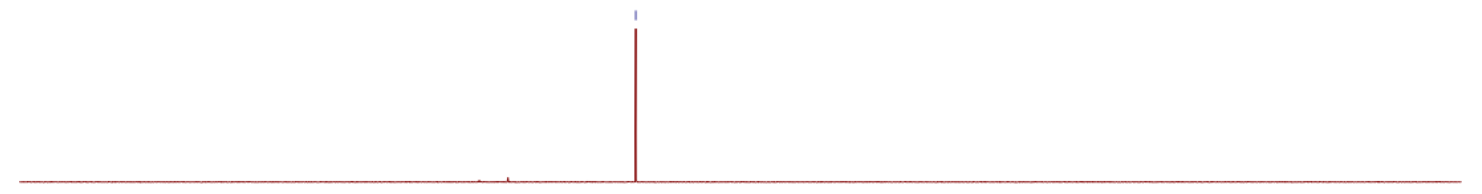



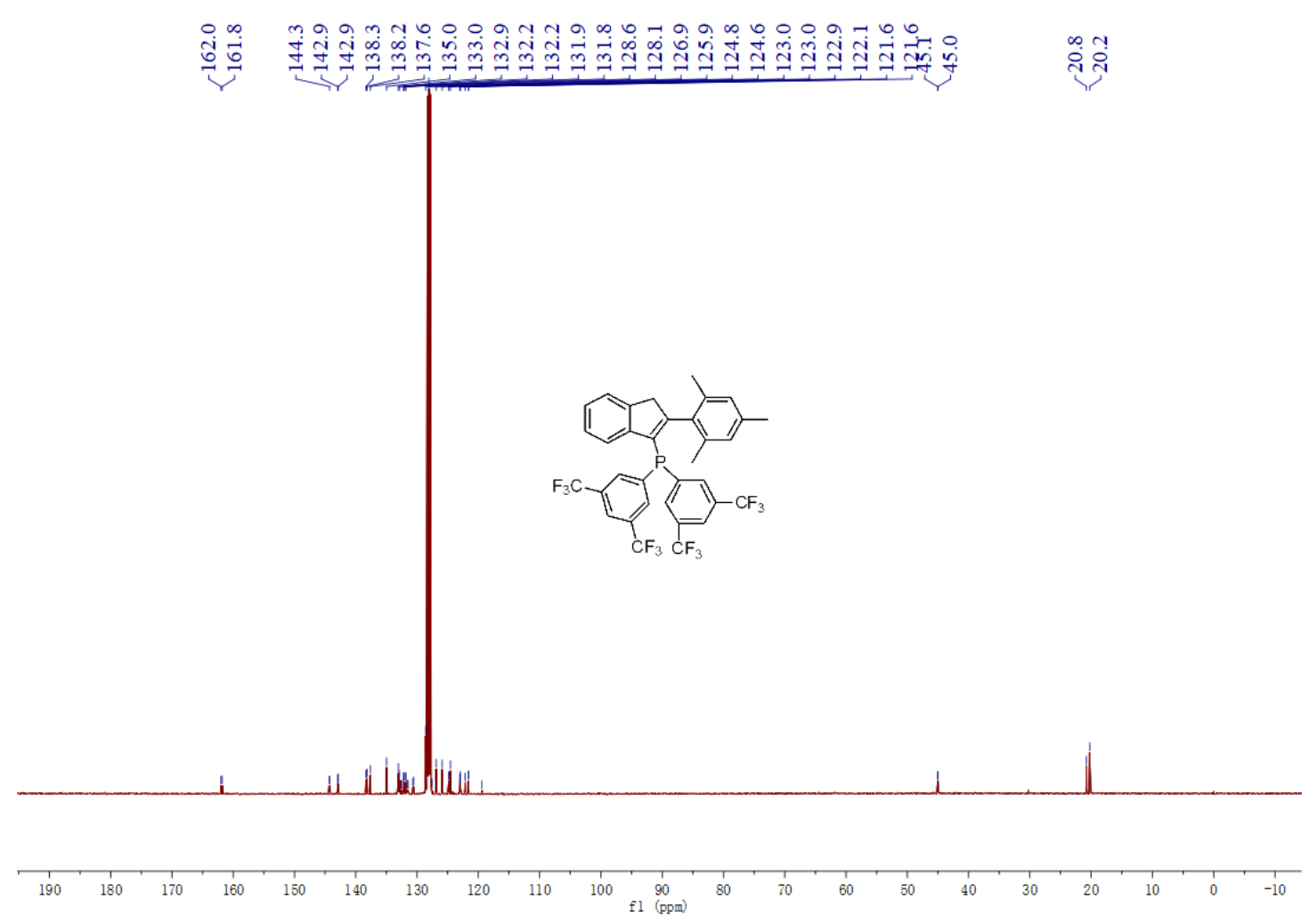

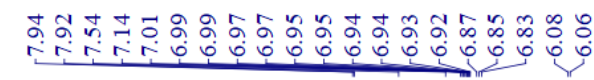

$\stackrel{\substack{2 \\ i}}{i}$

$\stackrel{\circ}{i}$
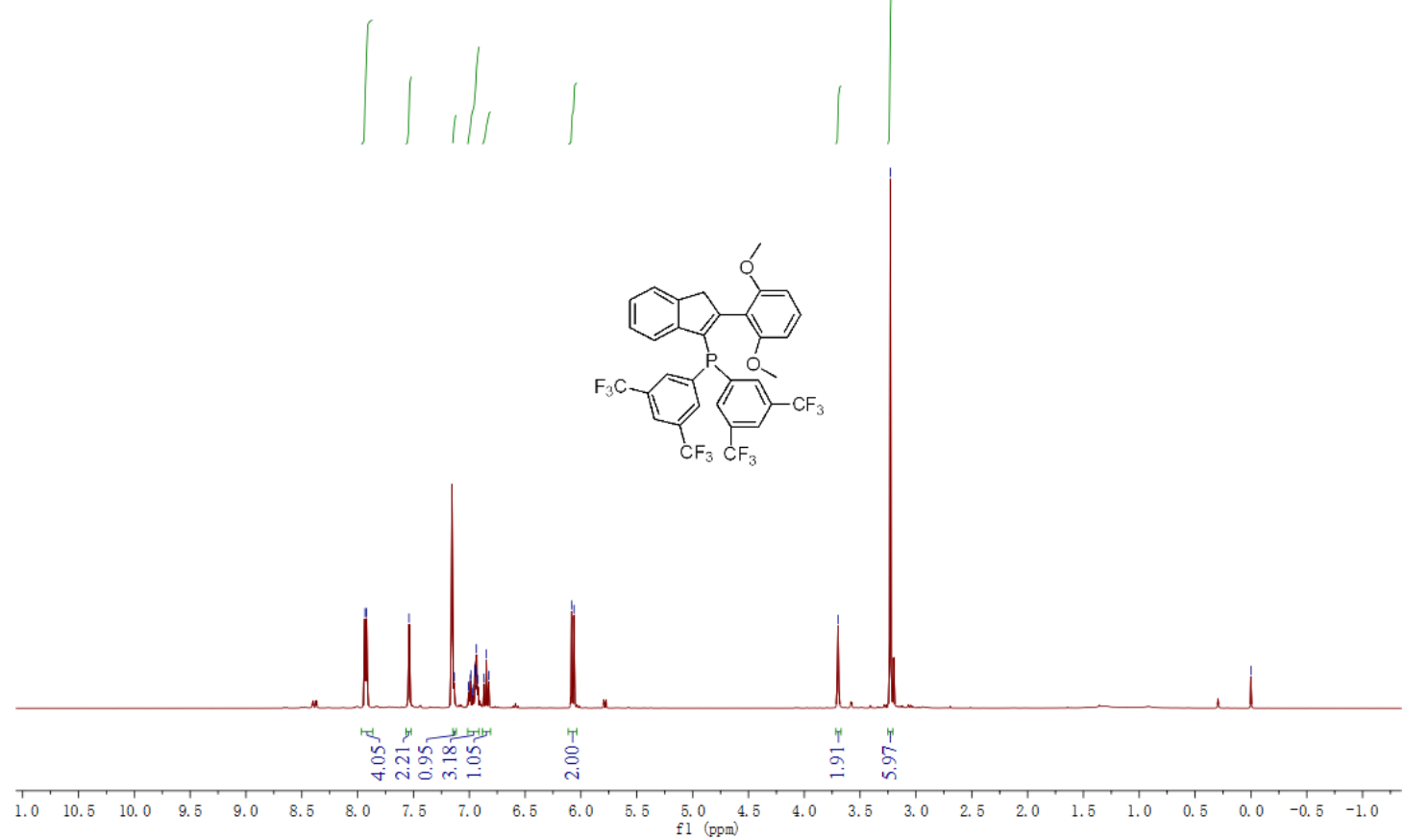


\section{\%}
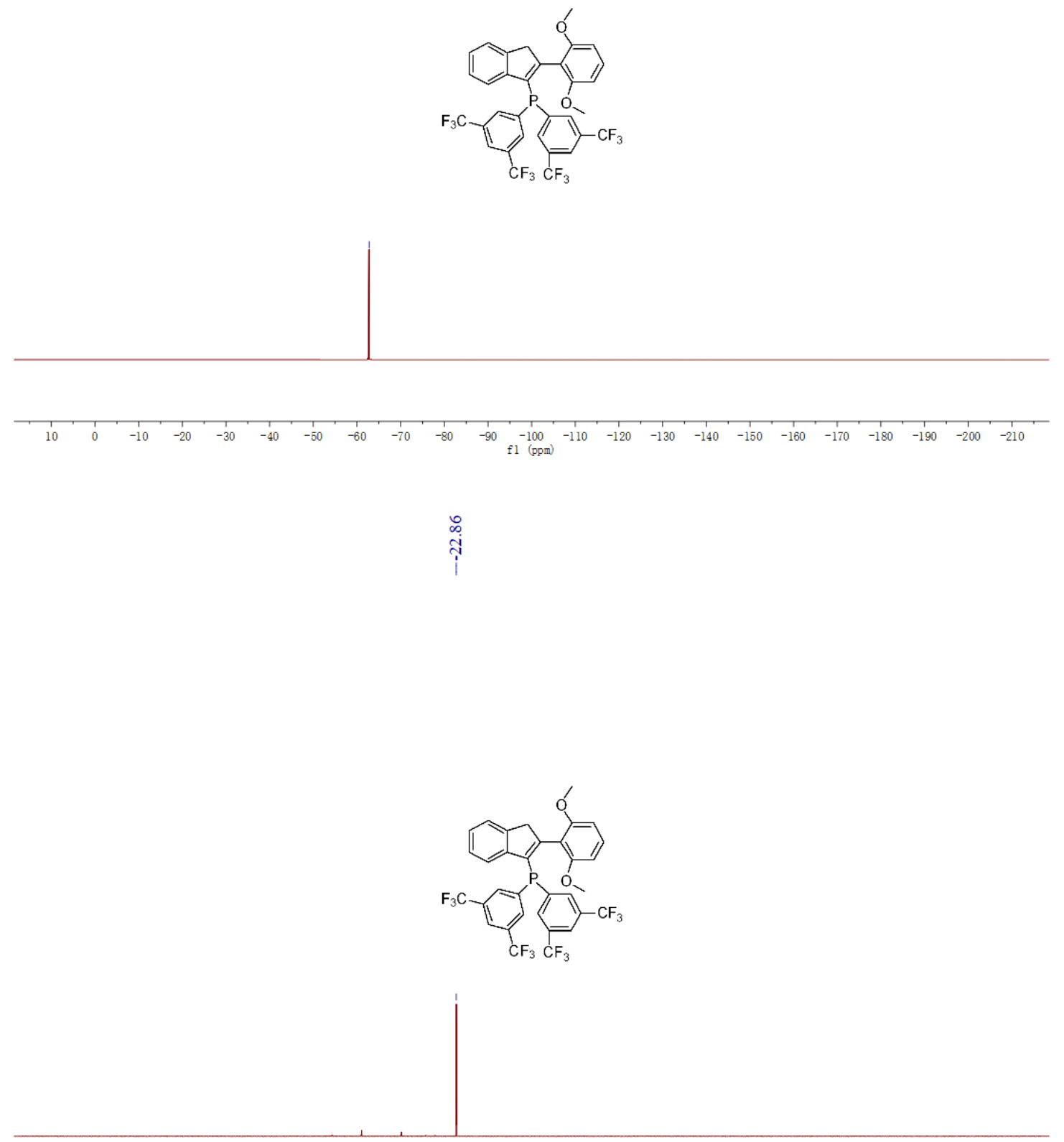

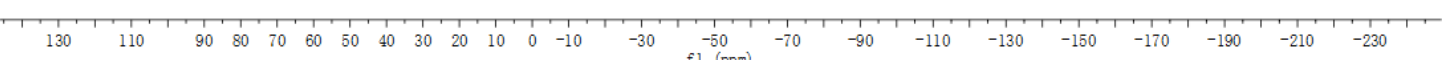



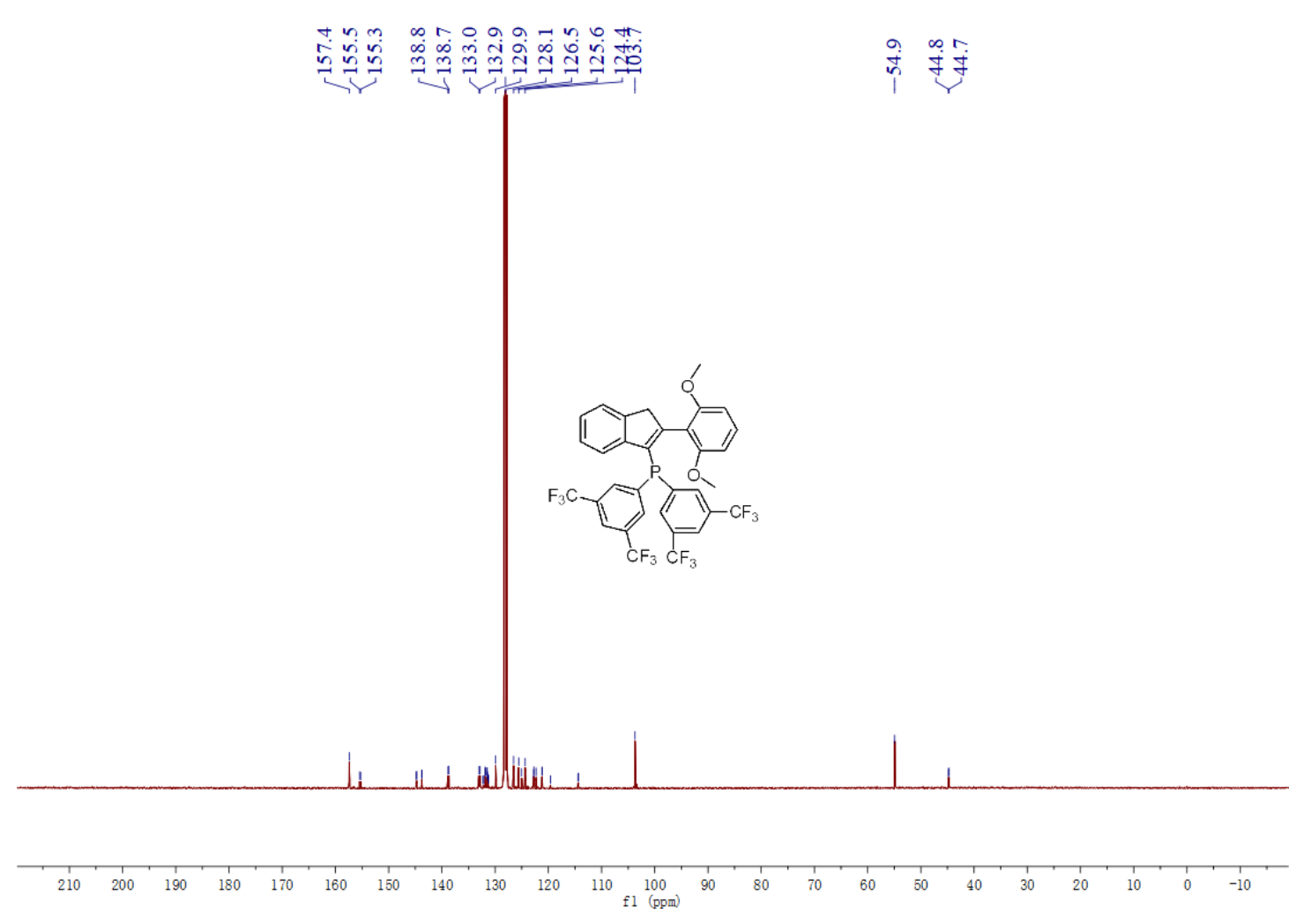

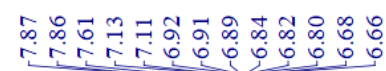

के
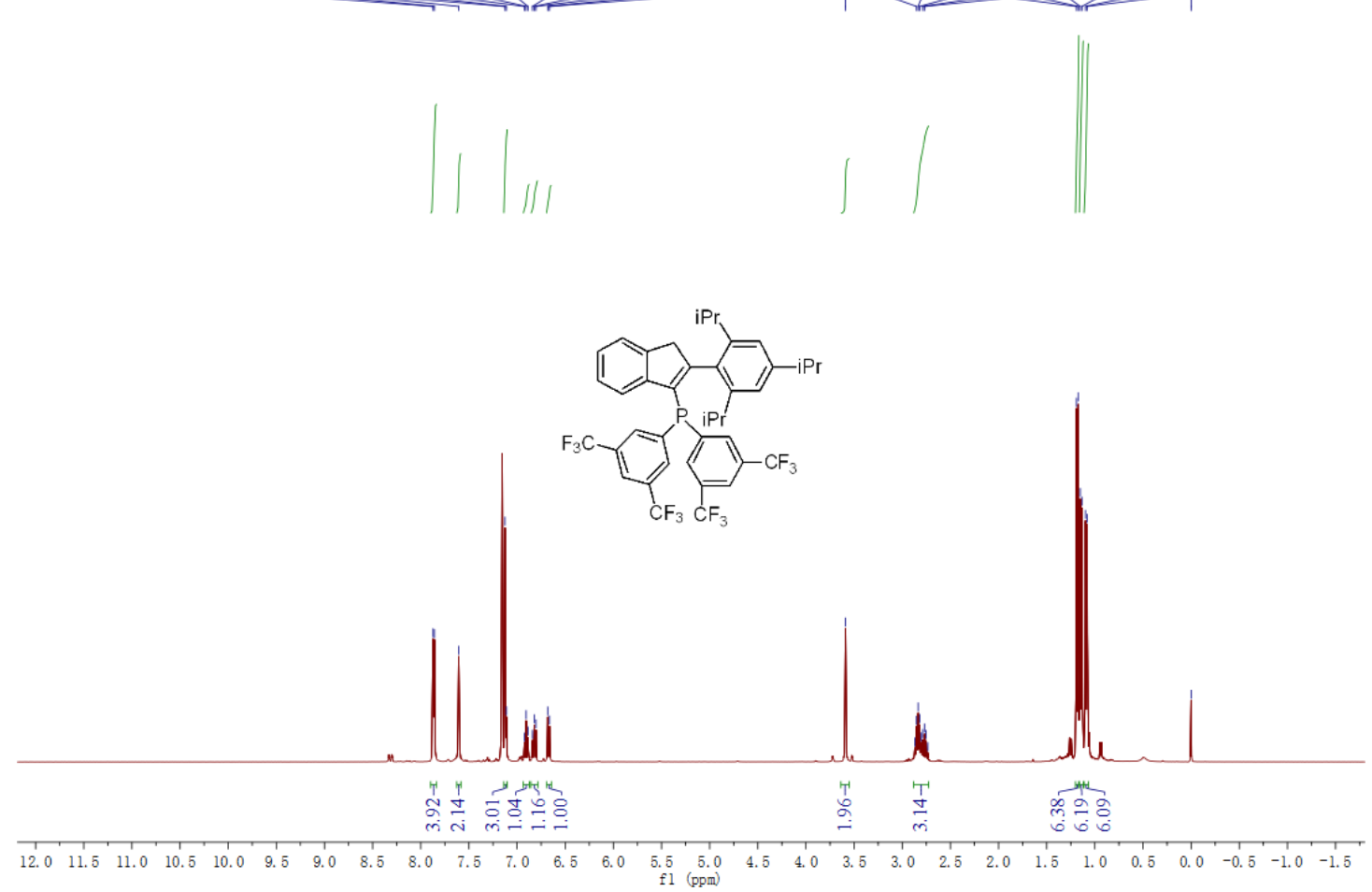
\%
ஸे
1
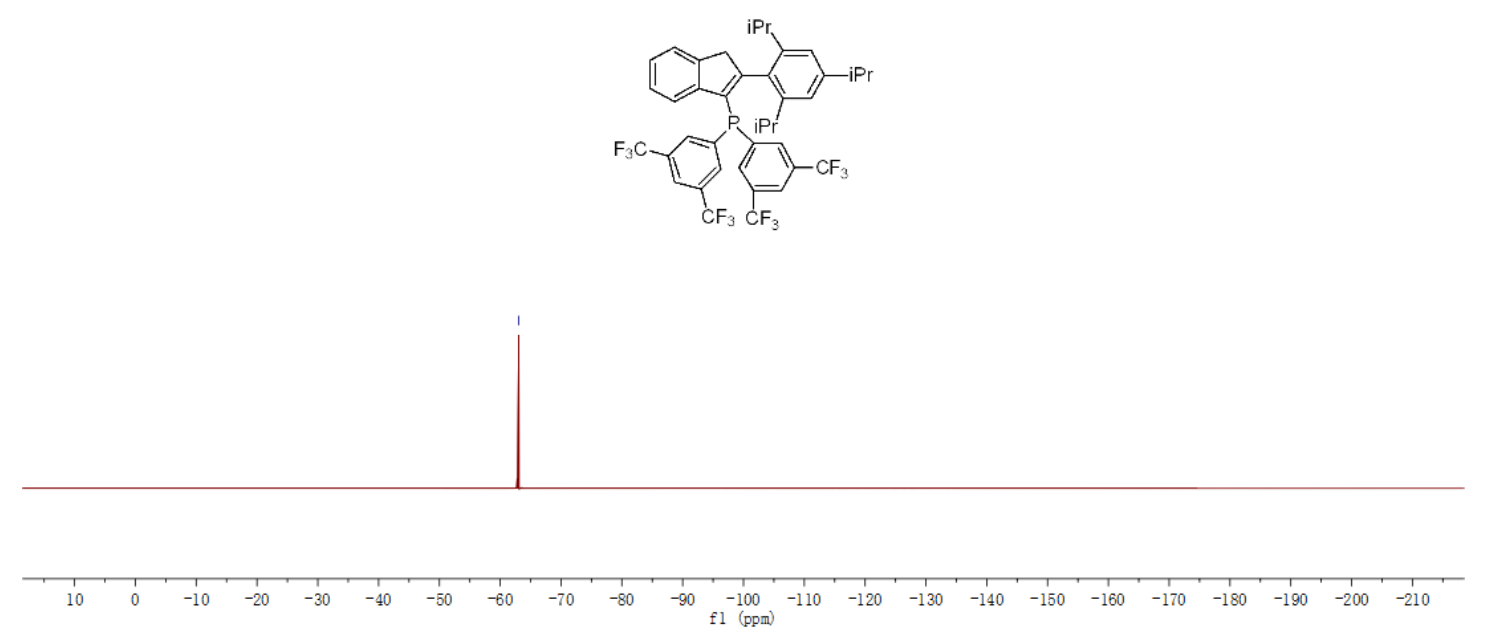

ํํํ

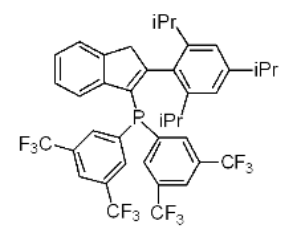

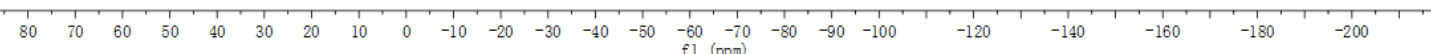



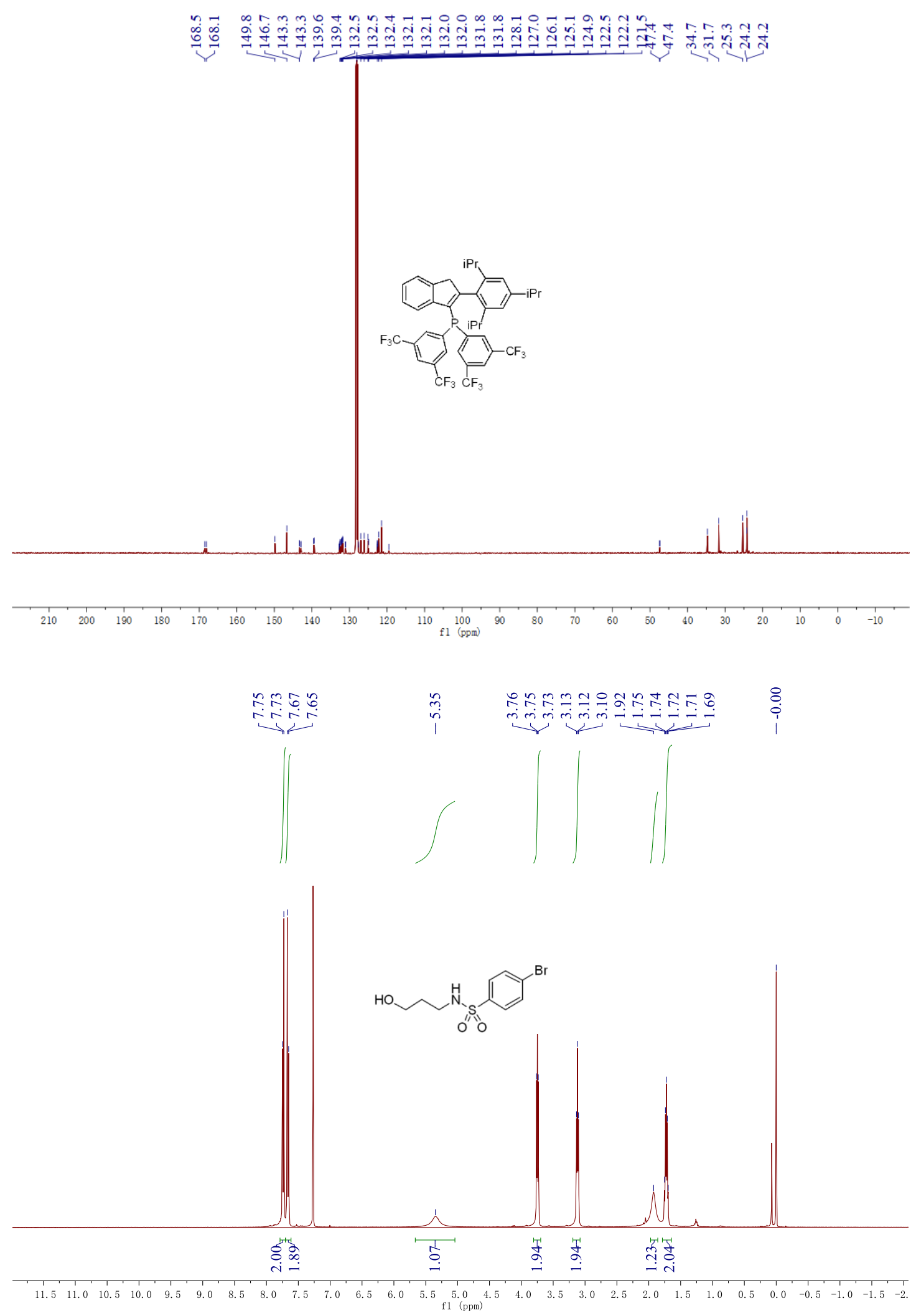


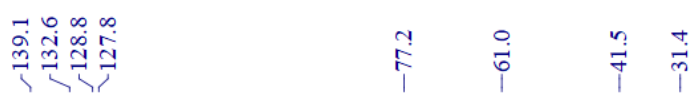
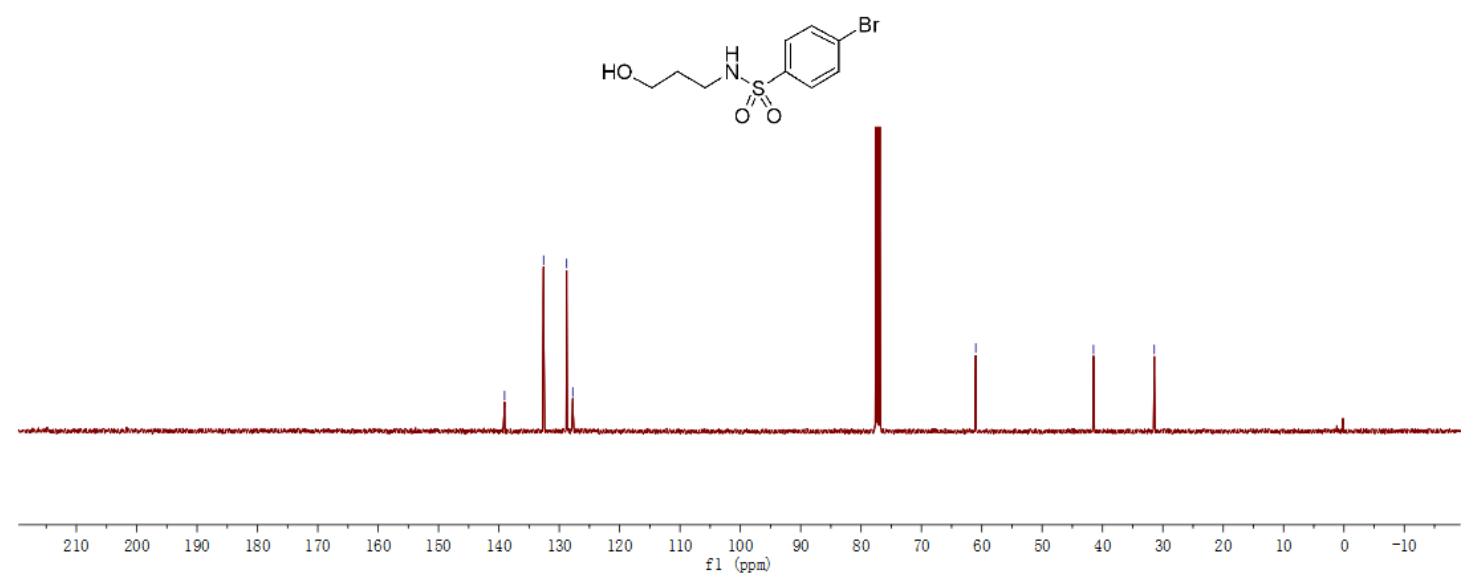

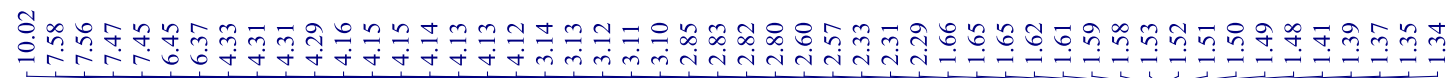
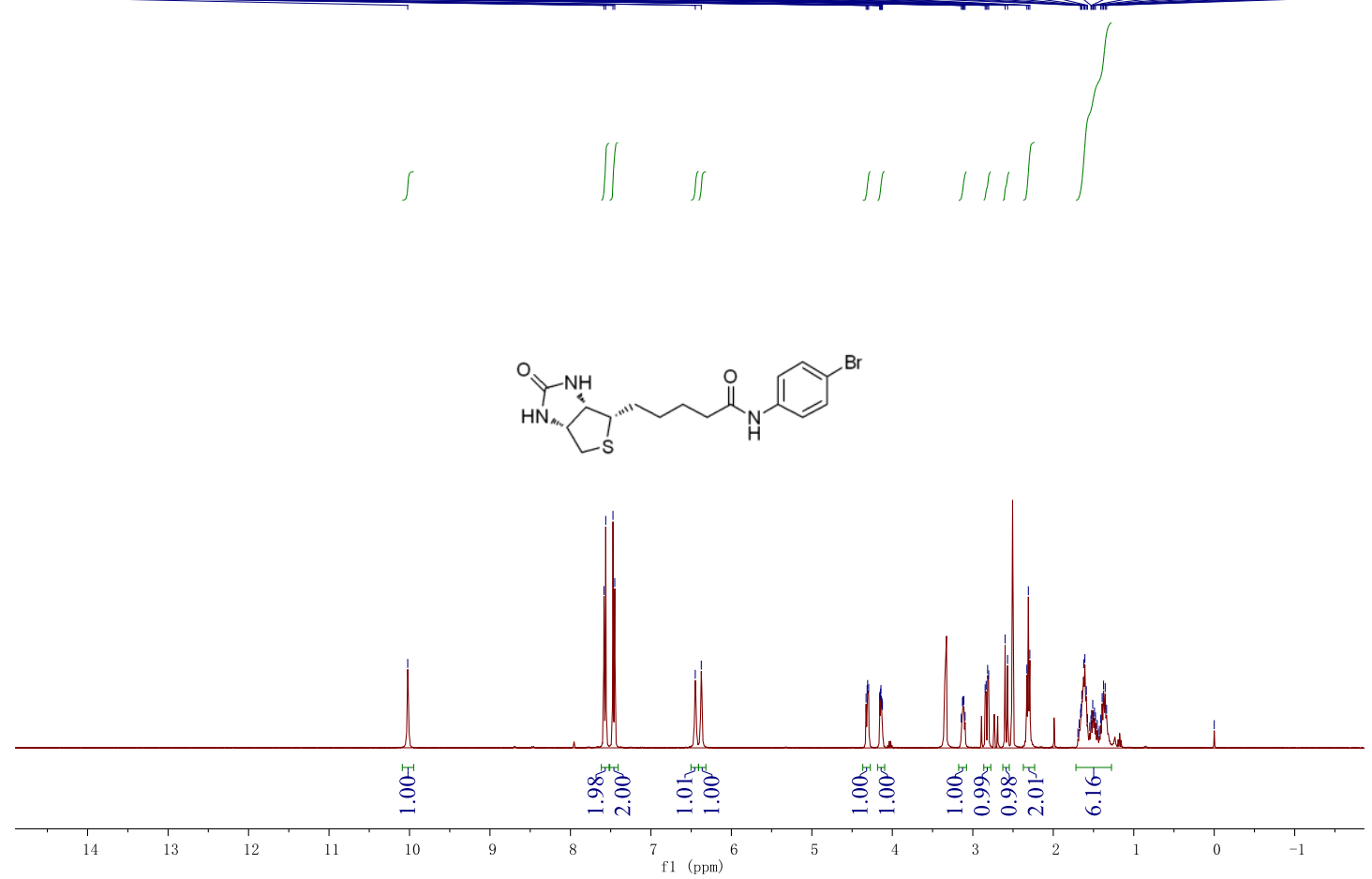

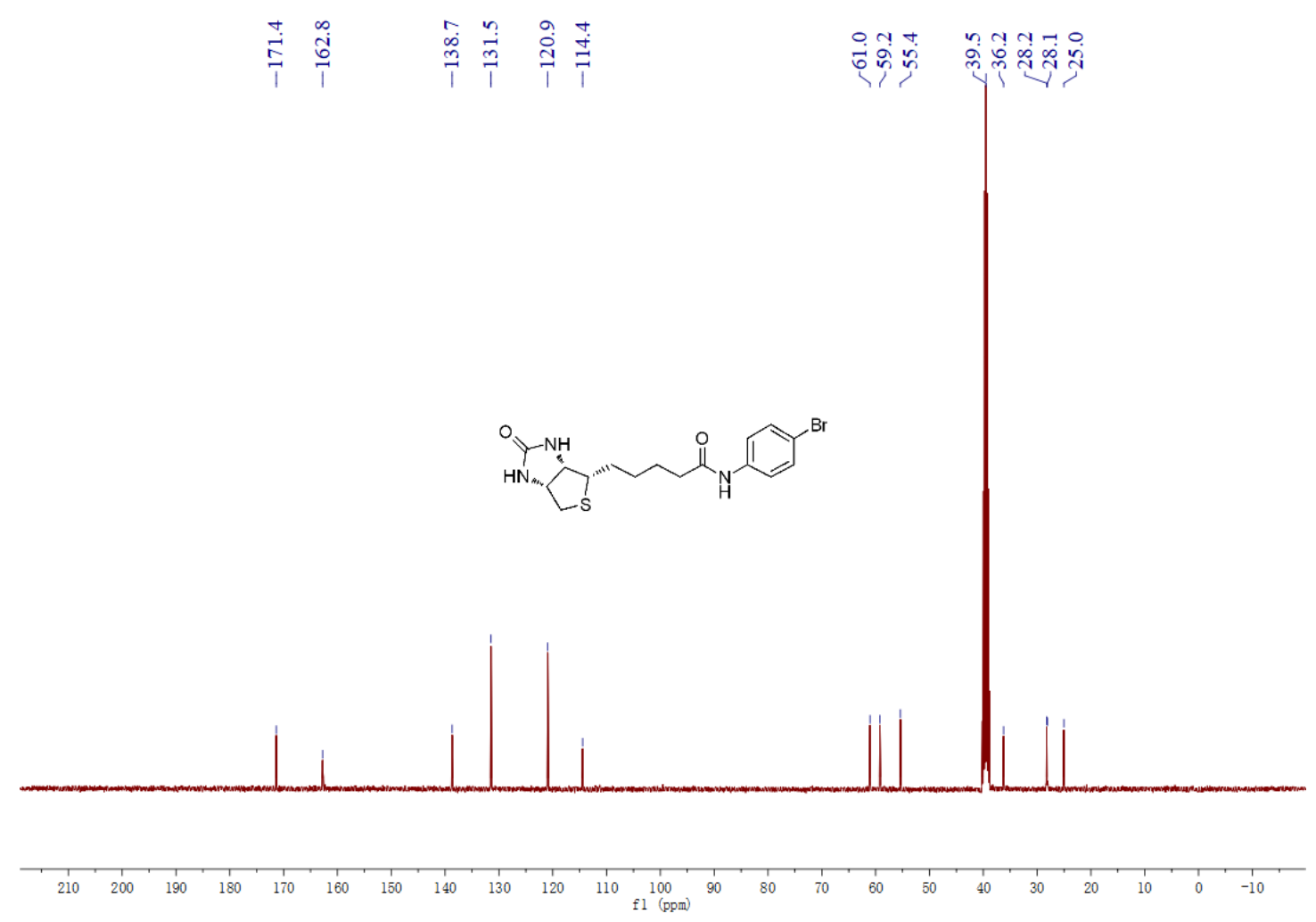

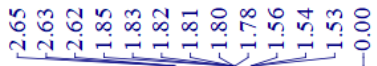

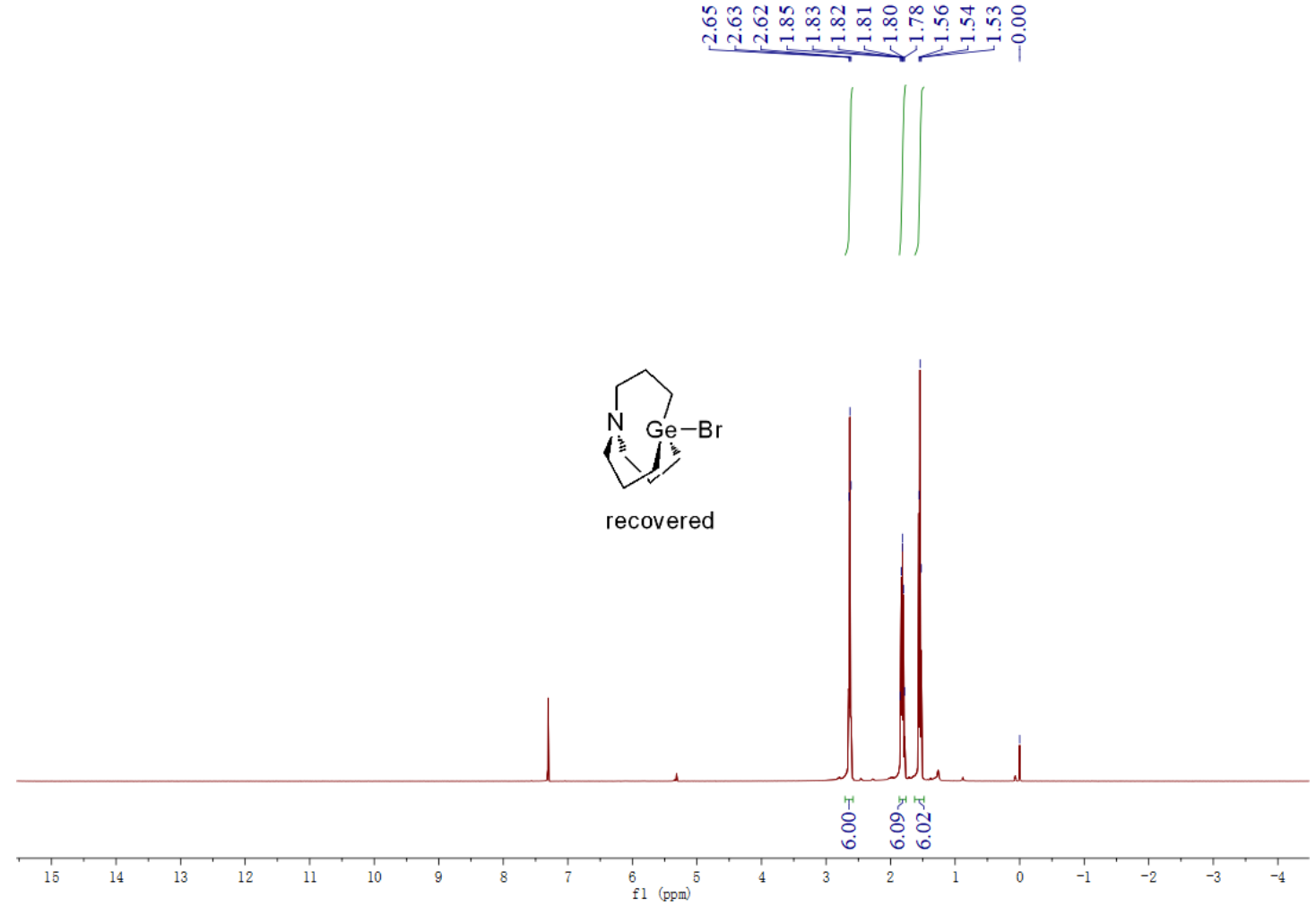


m.
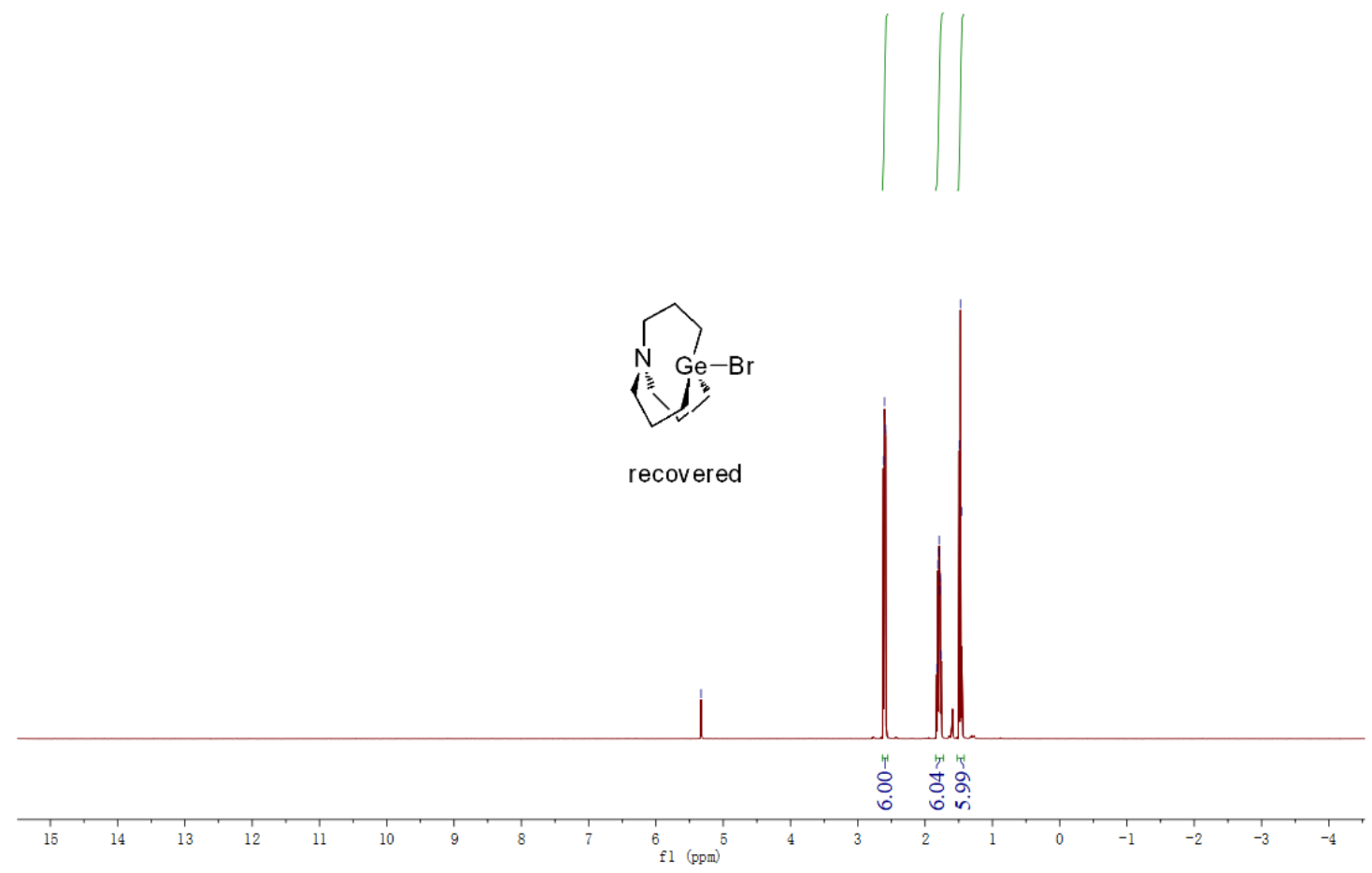

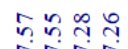

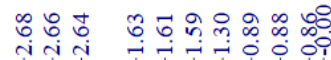

牙嵒

1

1
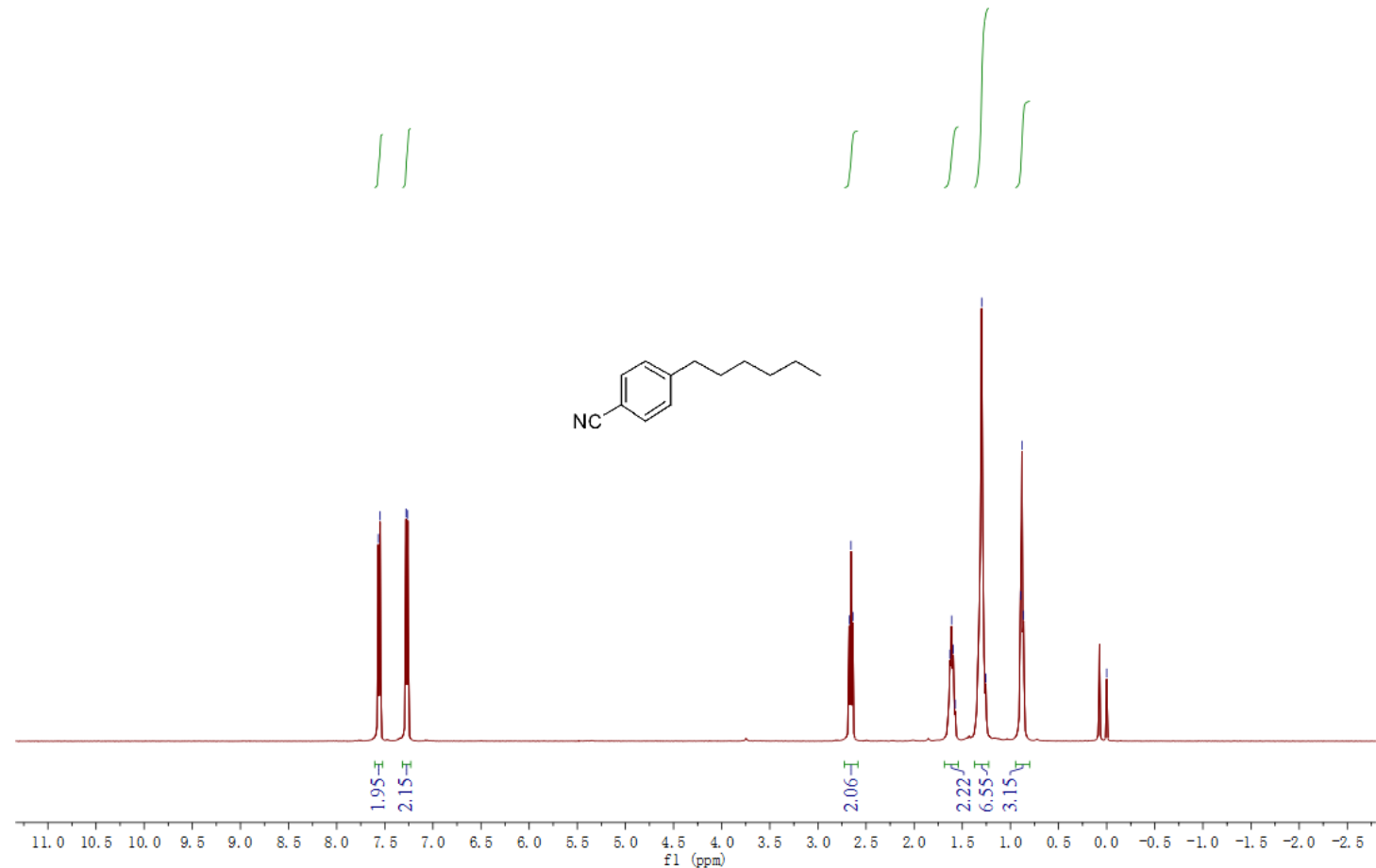

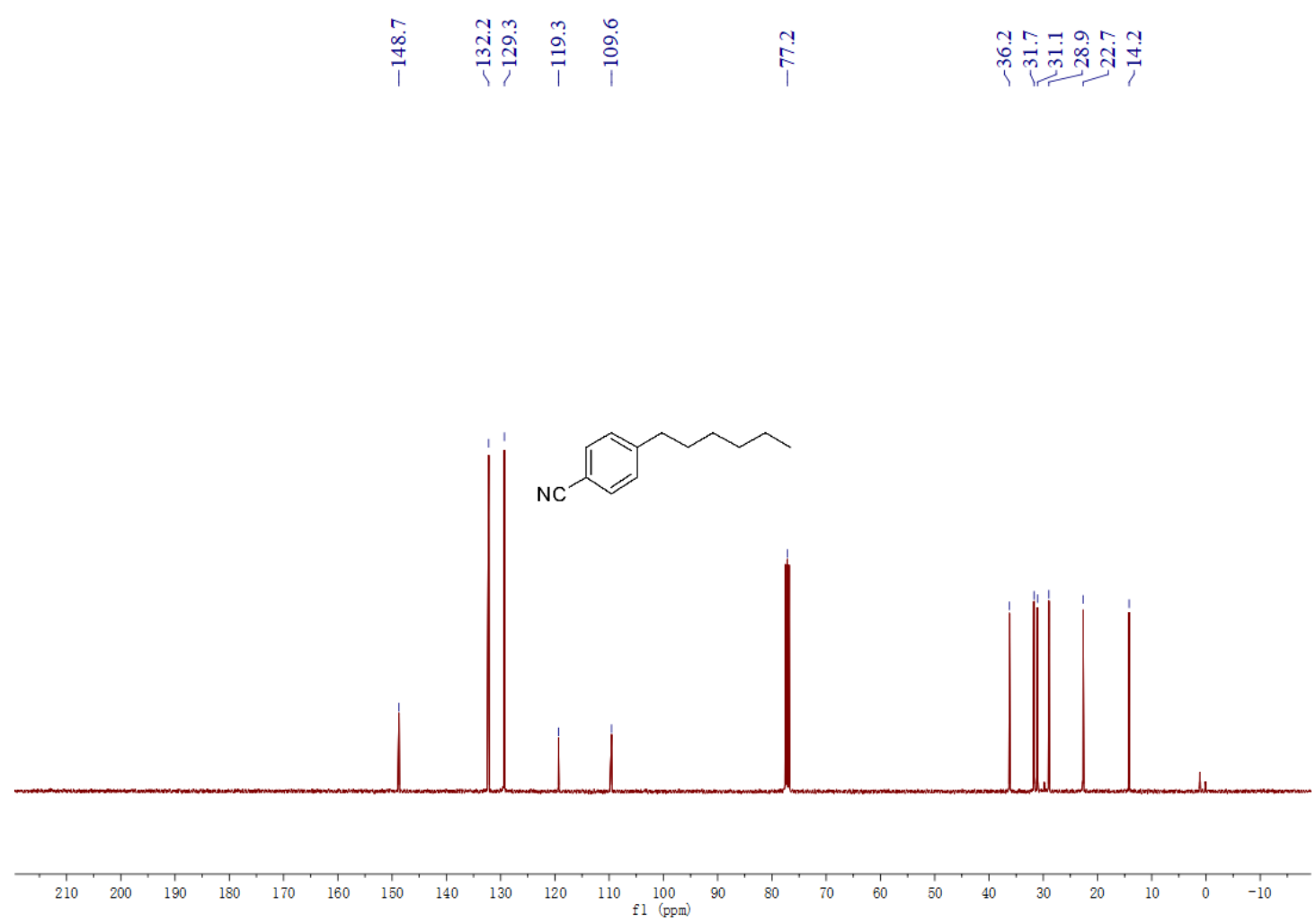

$\underbrace{n}_{\substack{n \\ \infty}}$

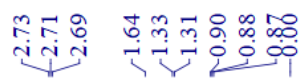

O

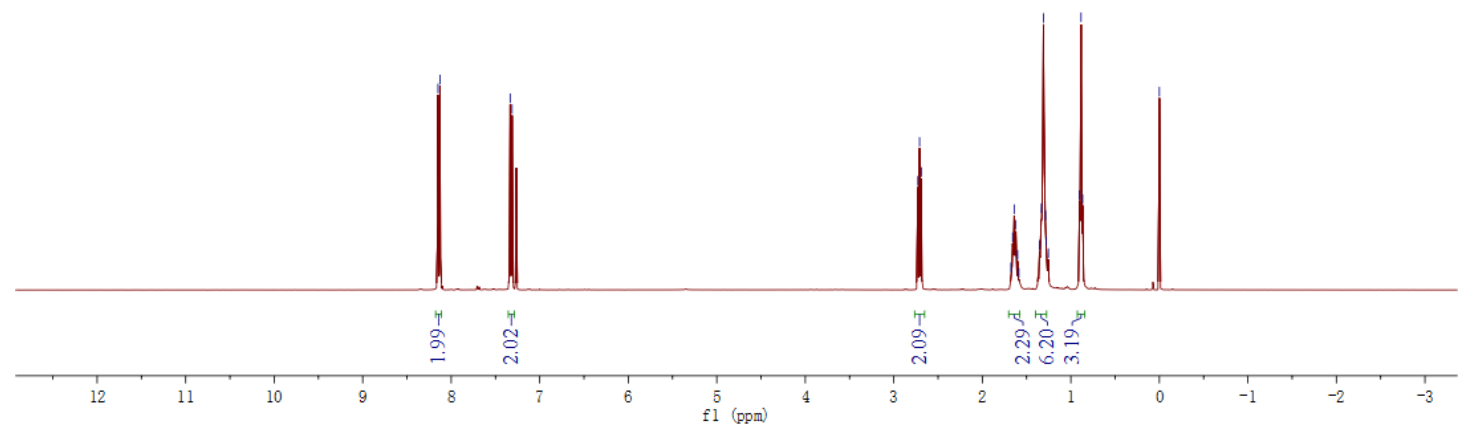


化
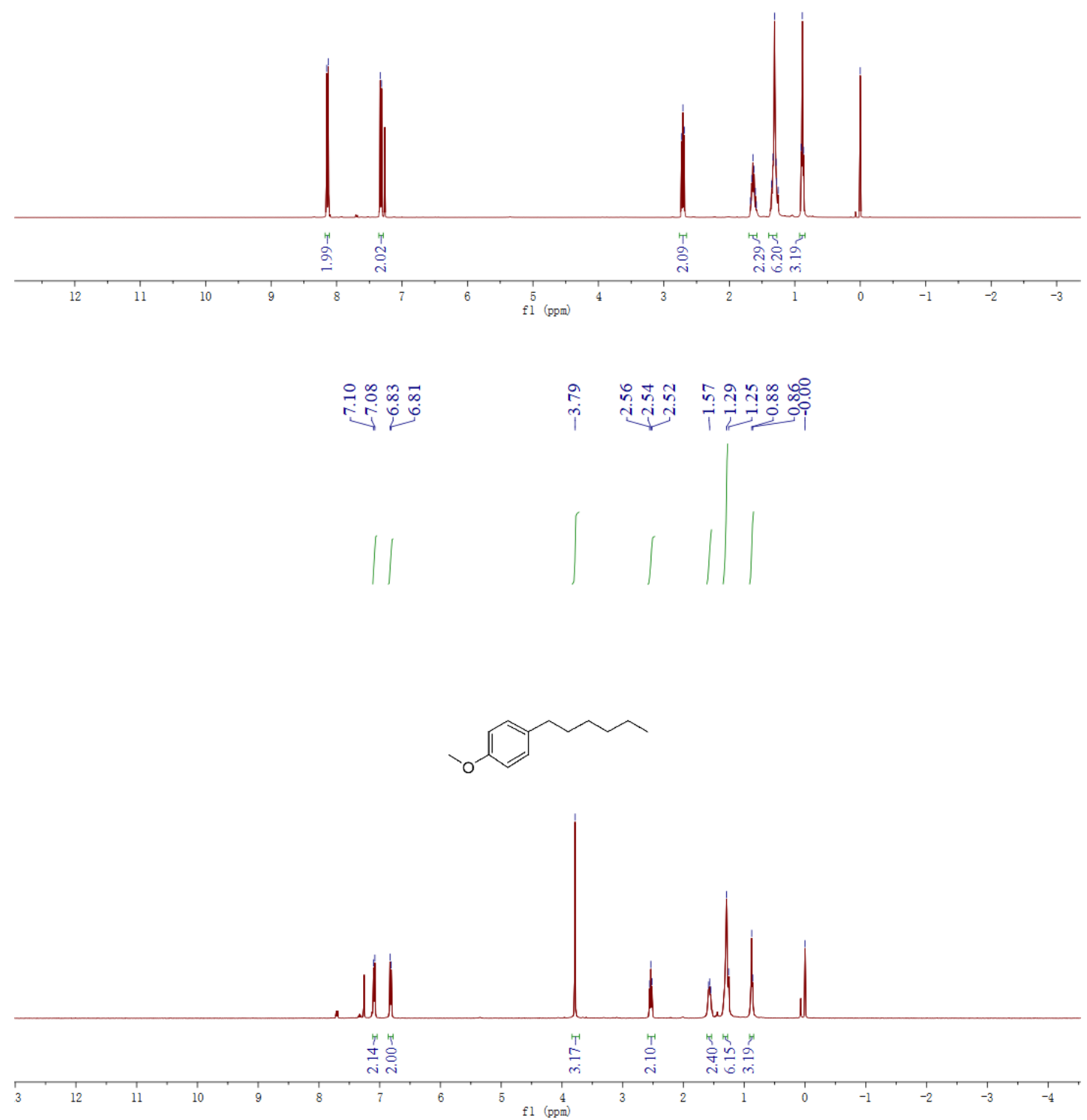


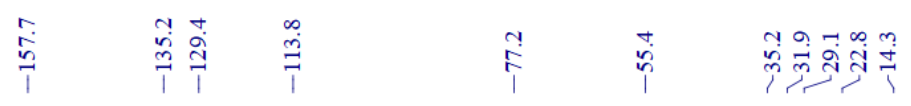
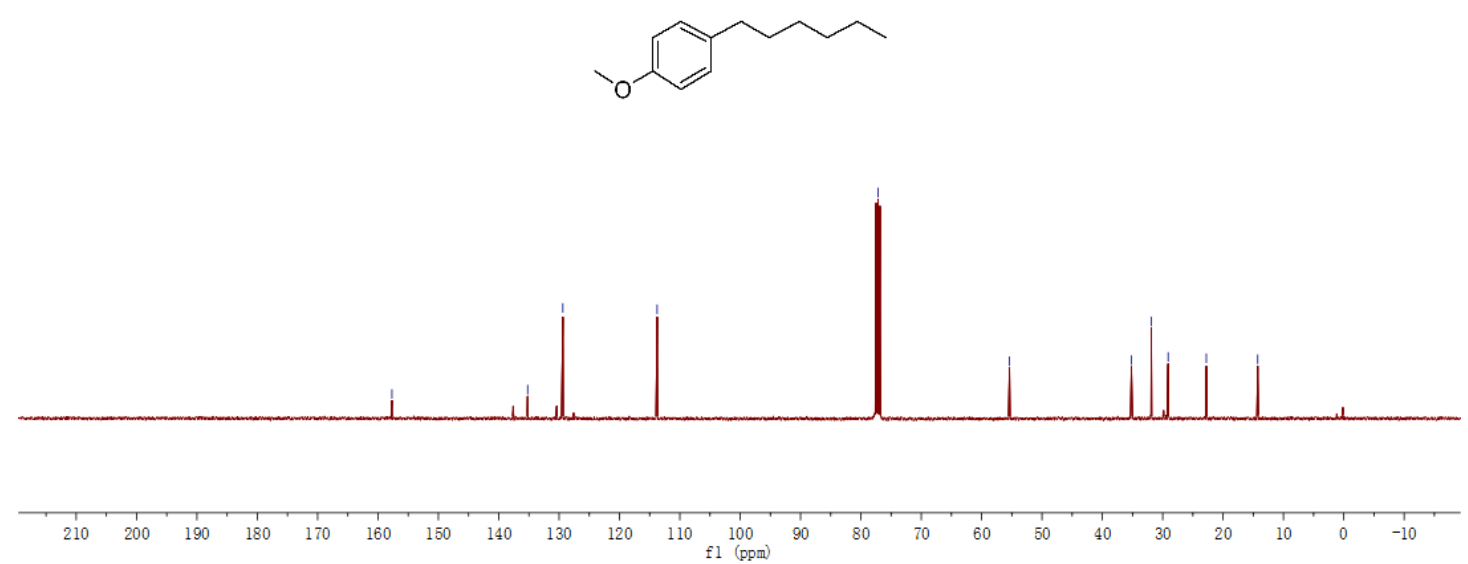

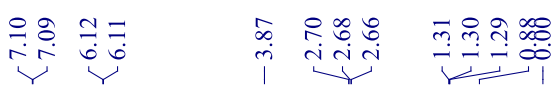

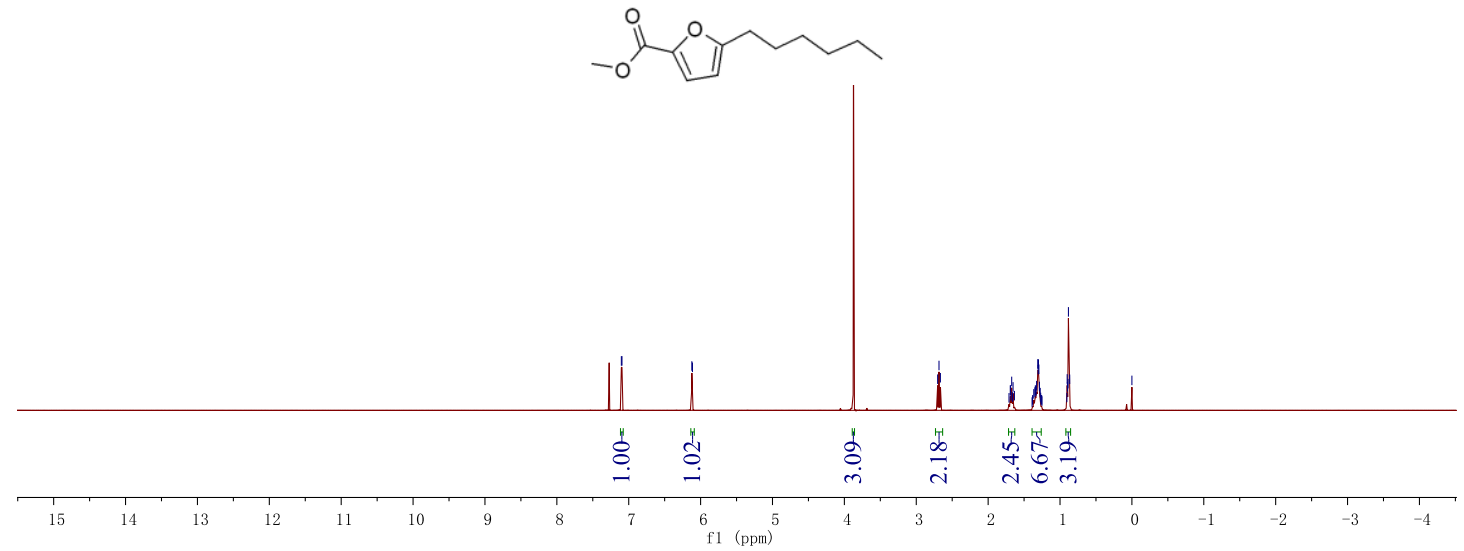




盯方
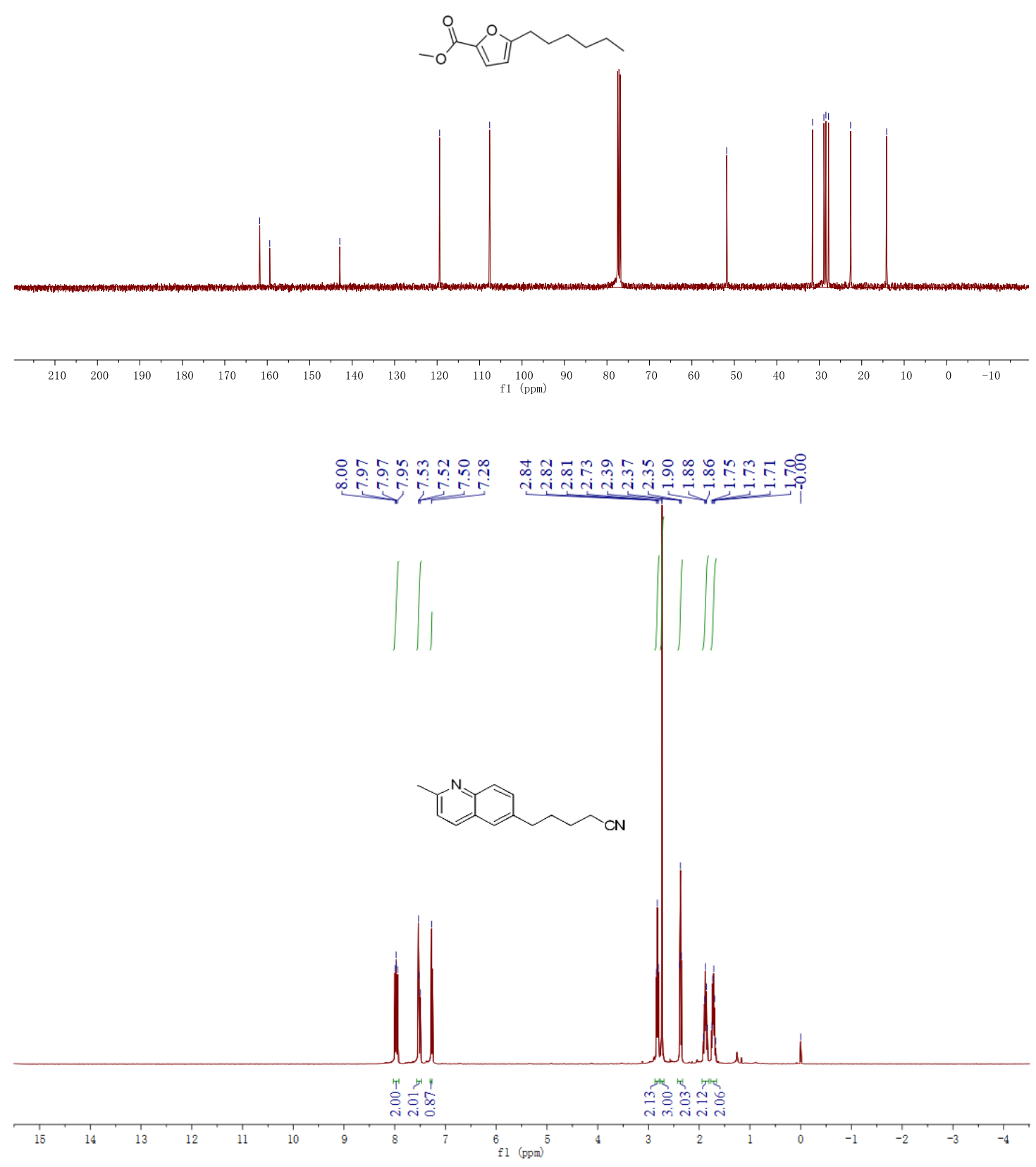


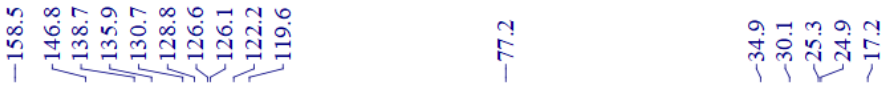
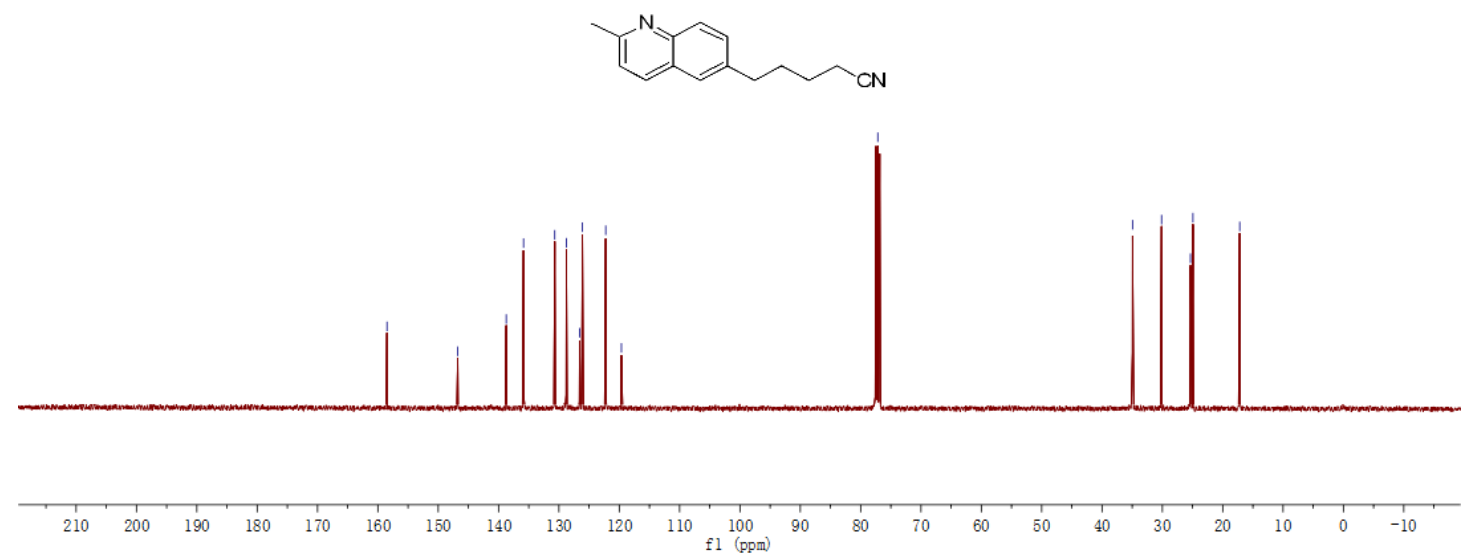

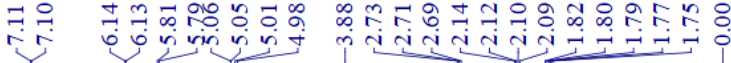

是近华=

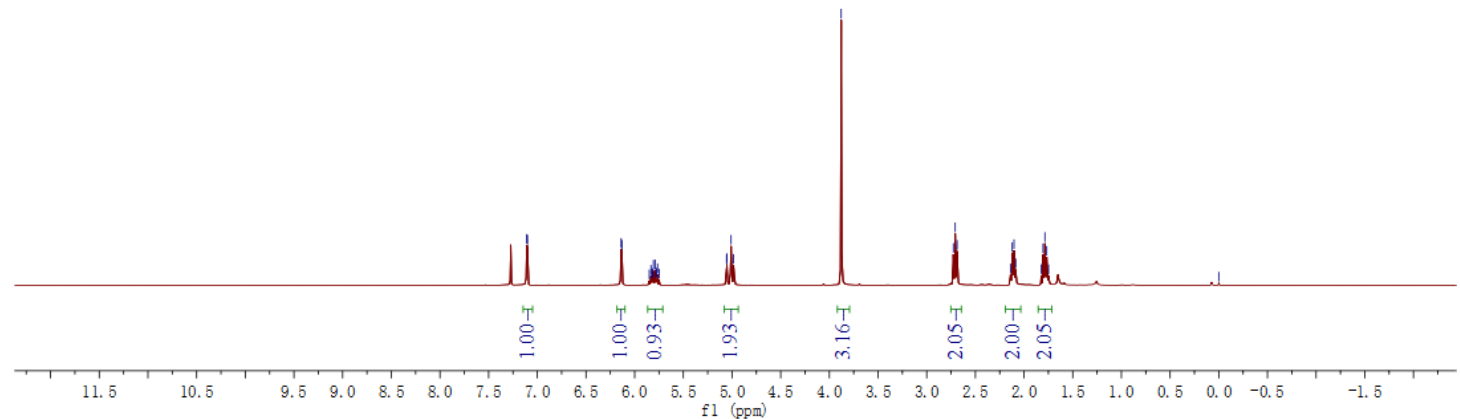




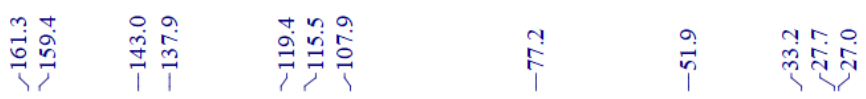
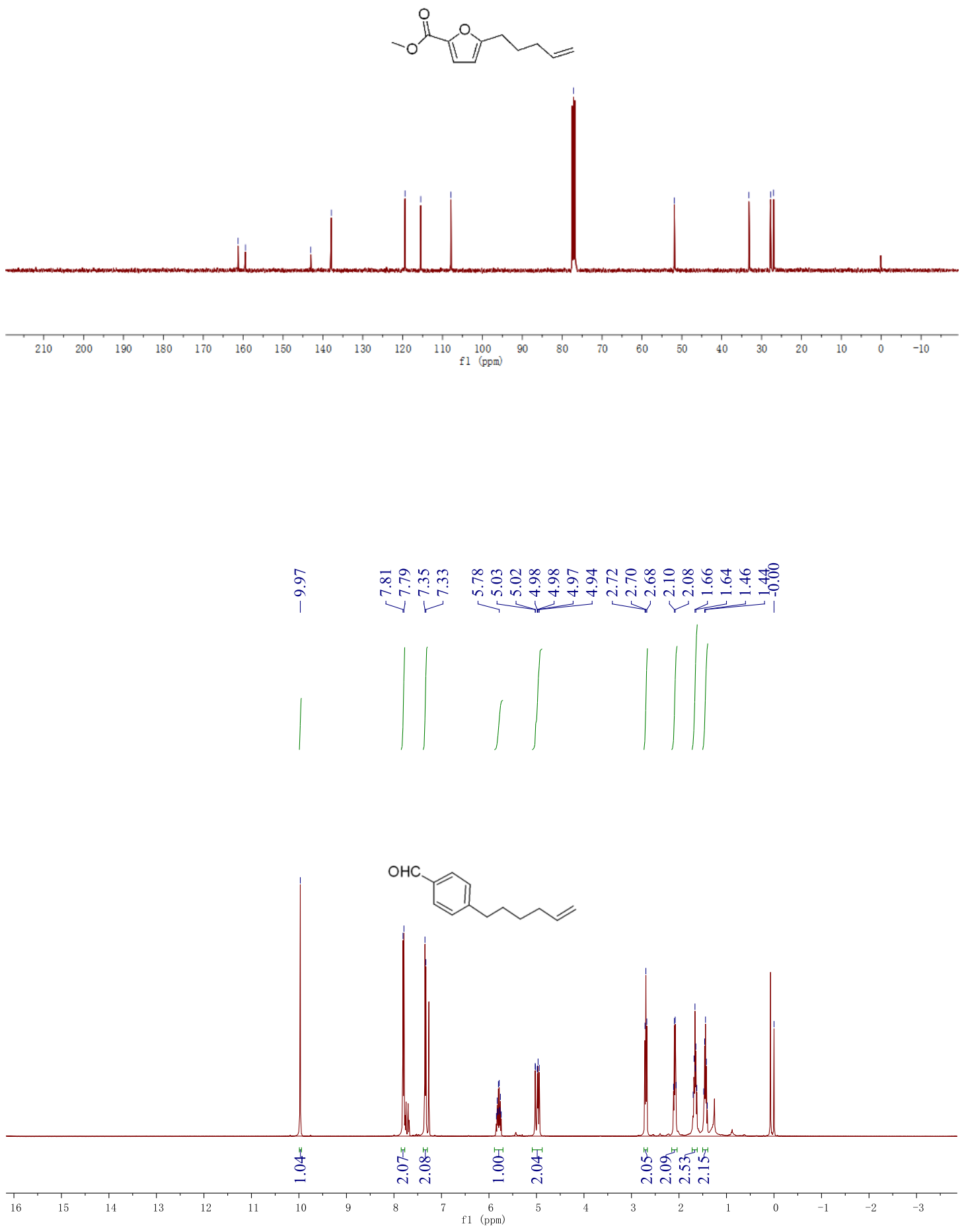

S101 


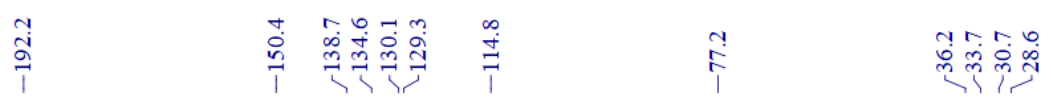

OHC

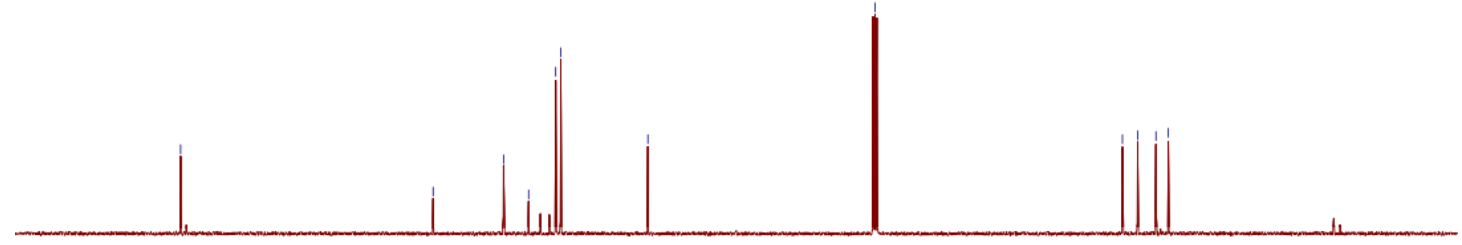

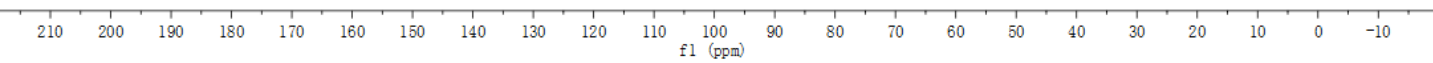

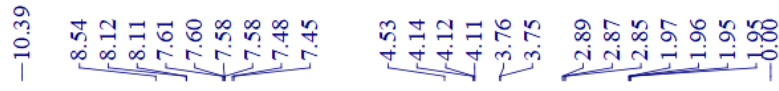

$\overbrace{}^{2}$

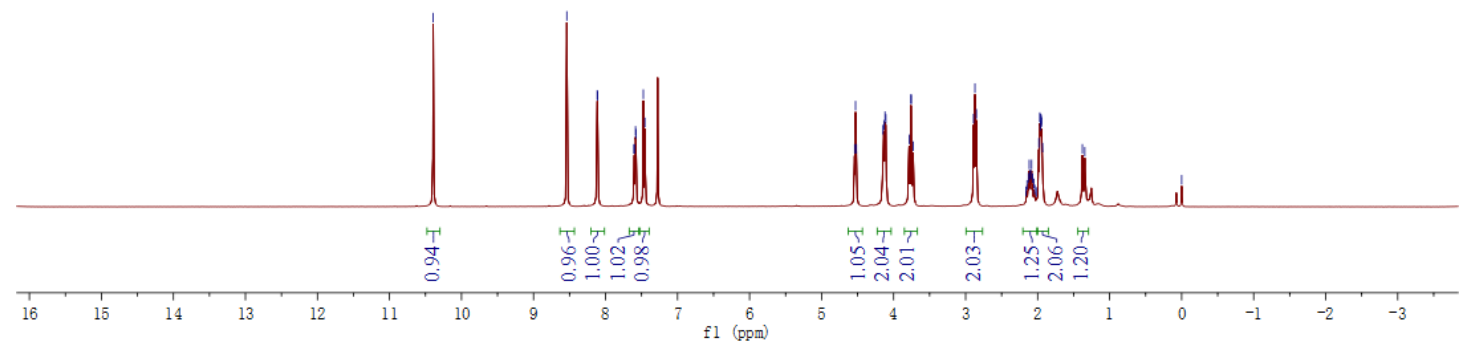



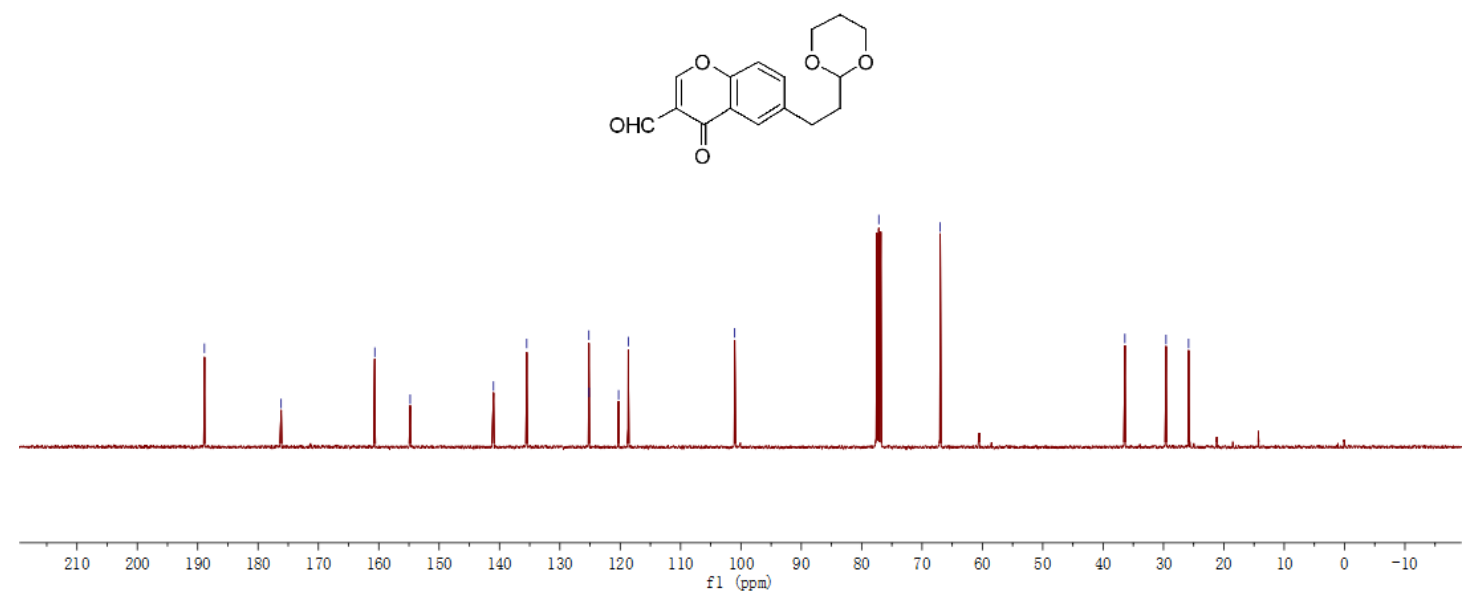

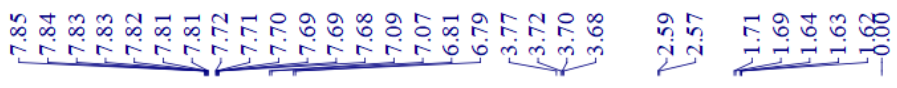

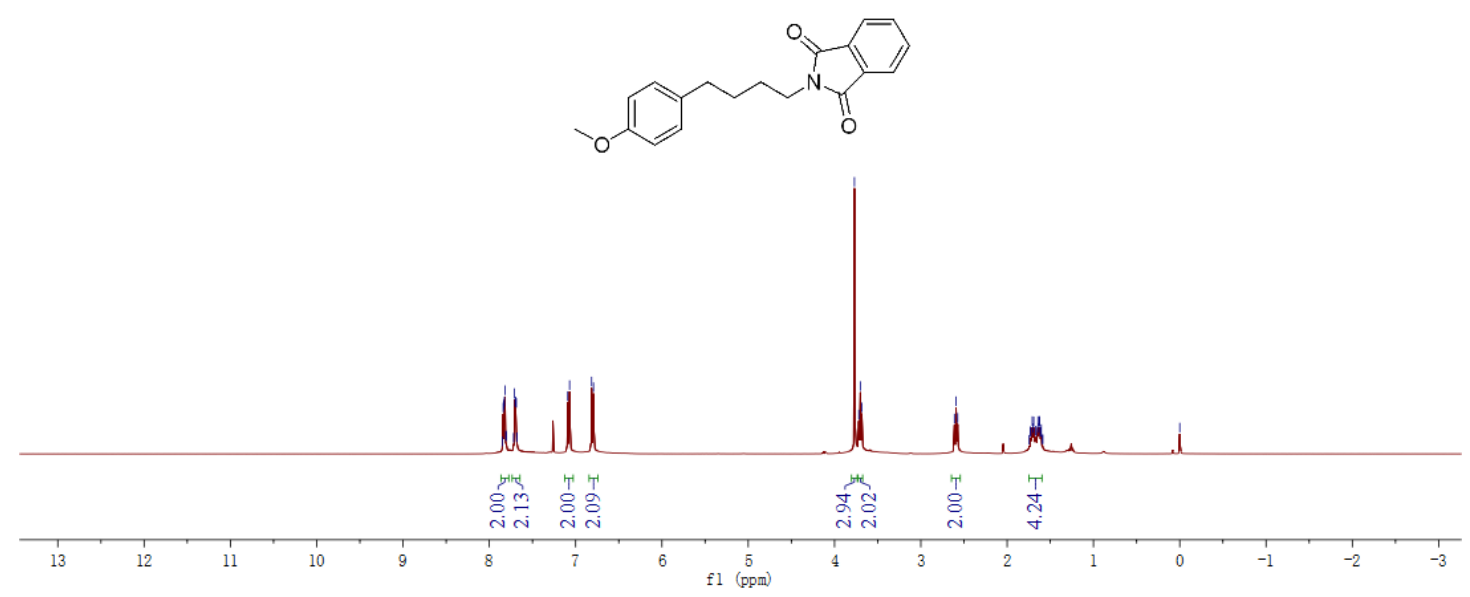




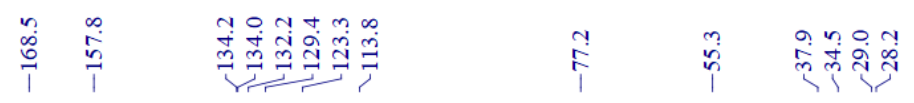
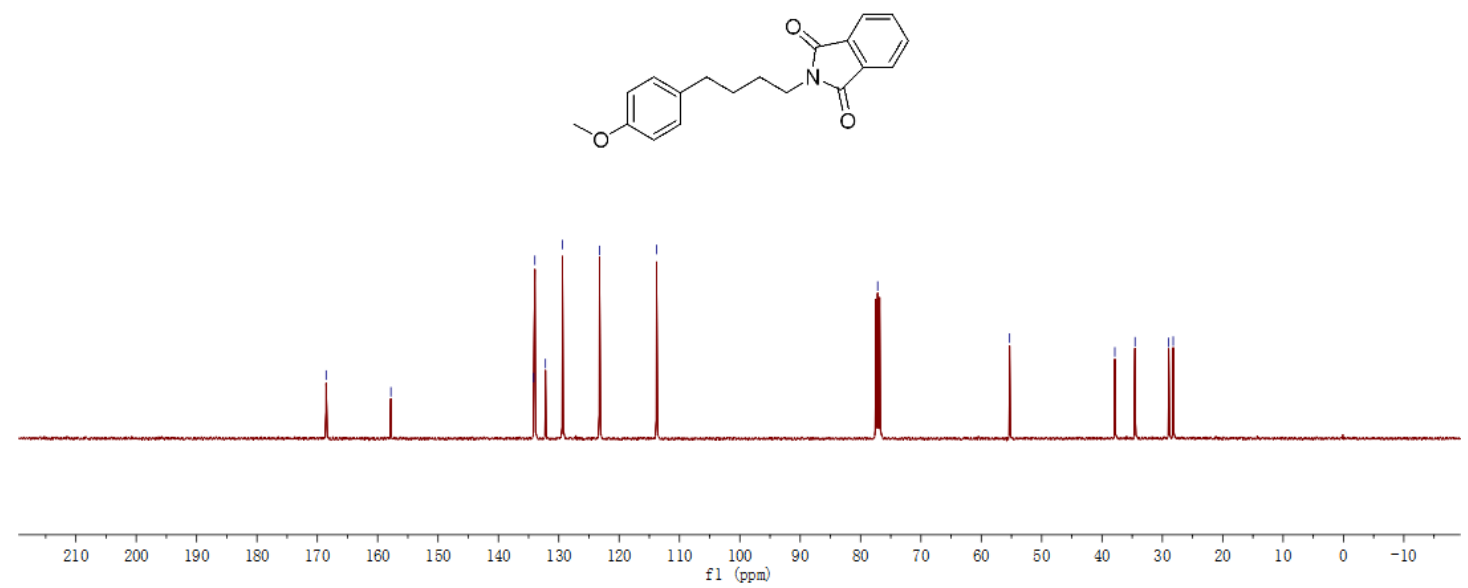

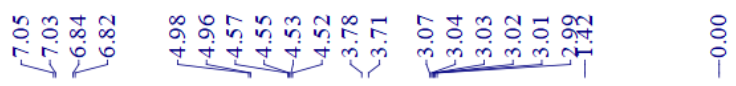

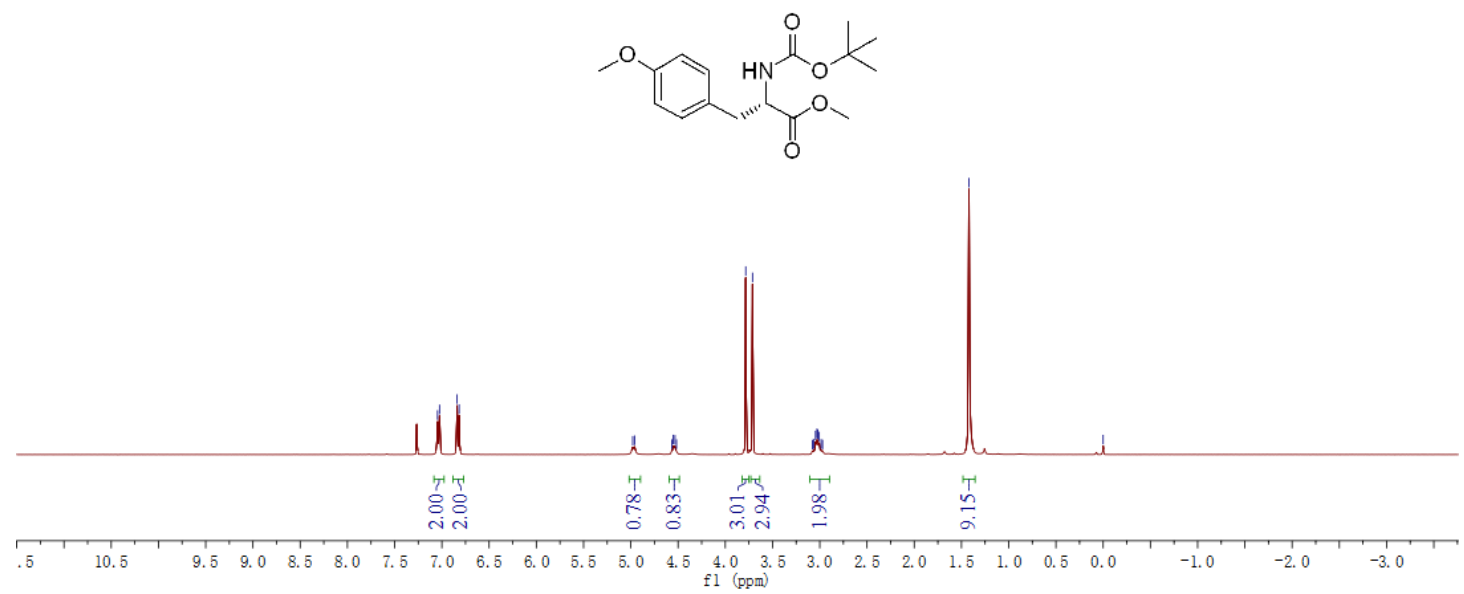




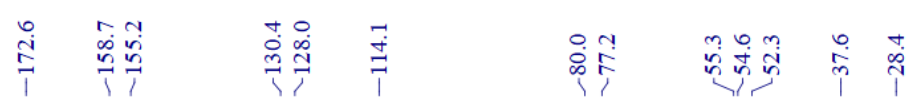
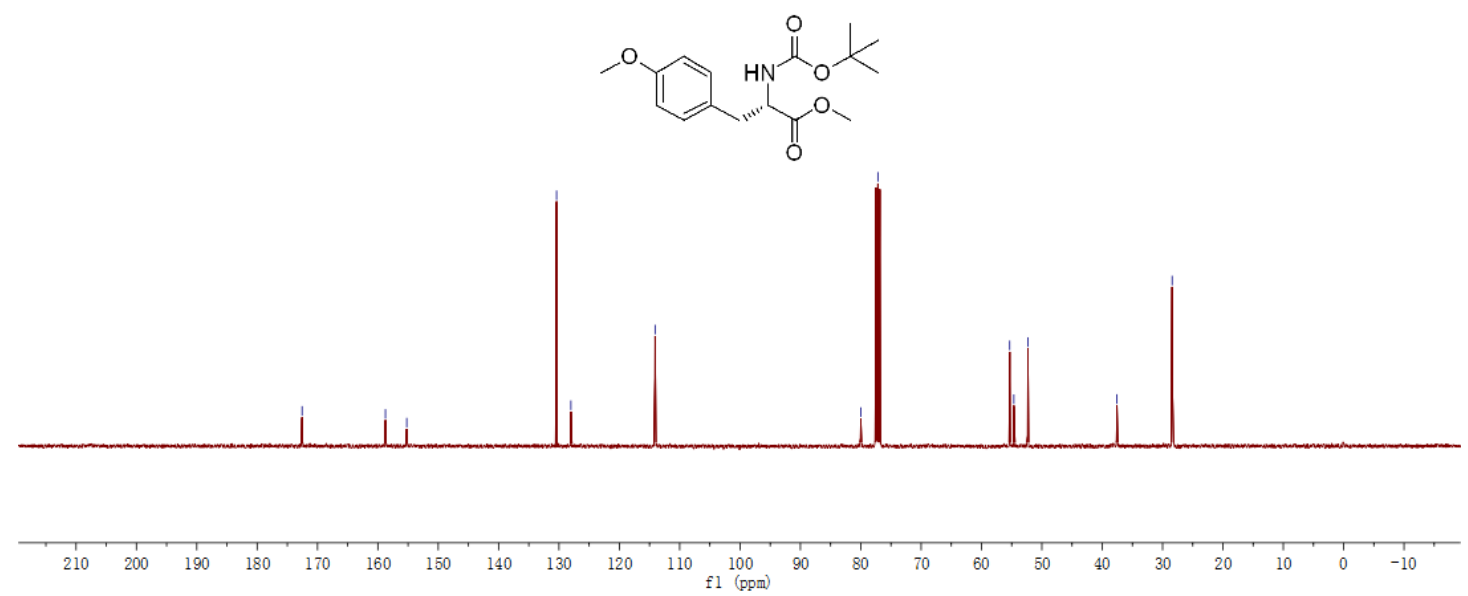

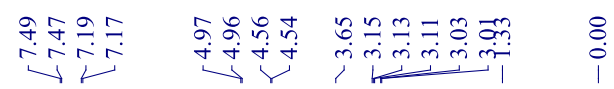

$\iint S \iint j$

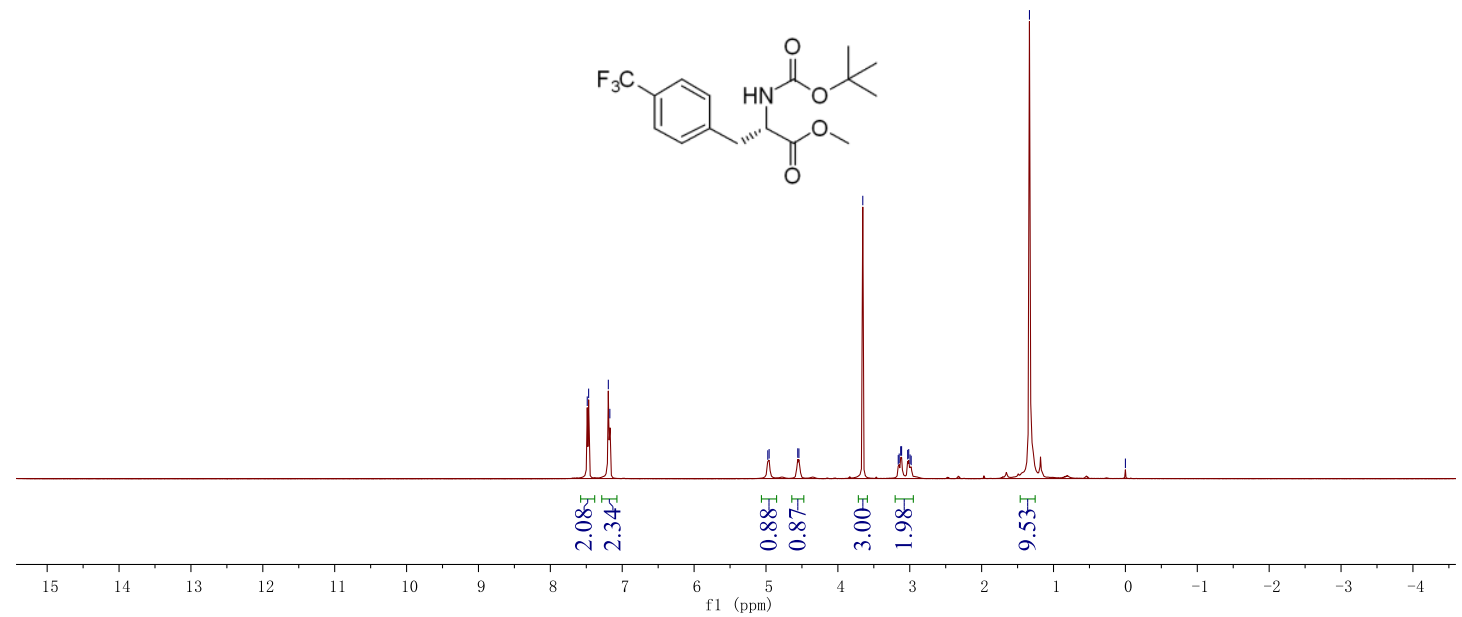



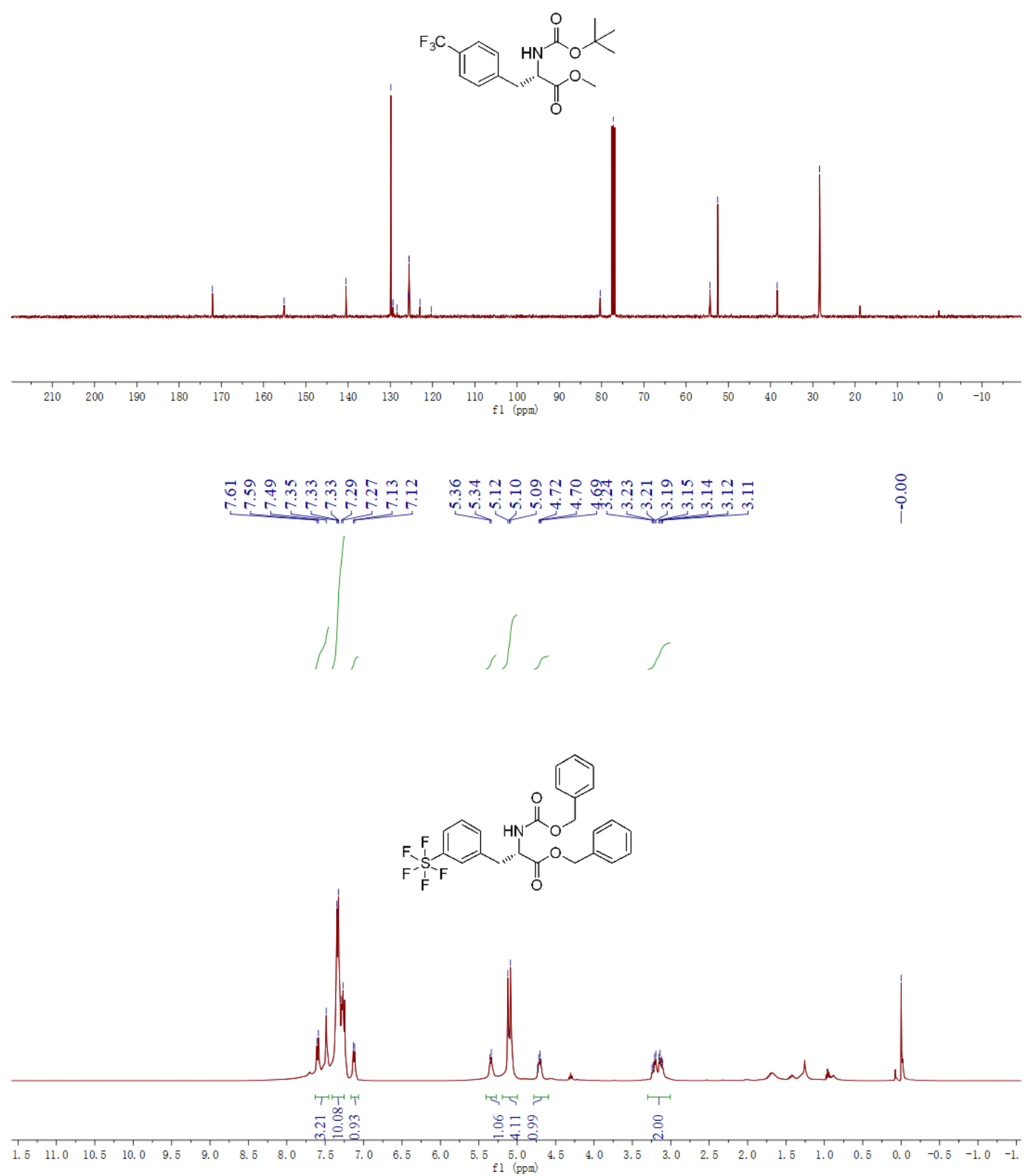


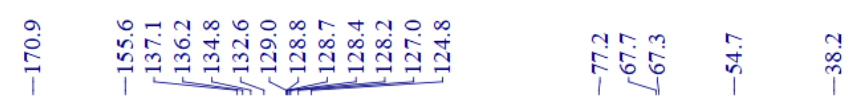
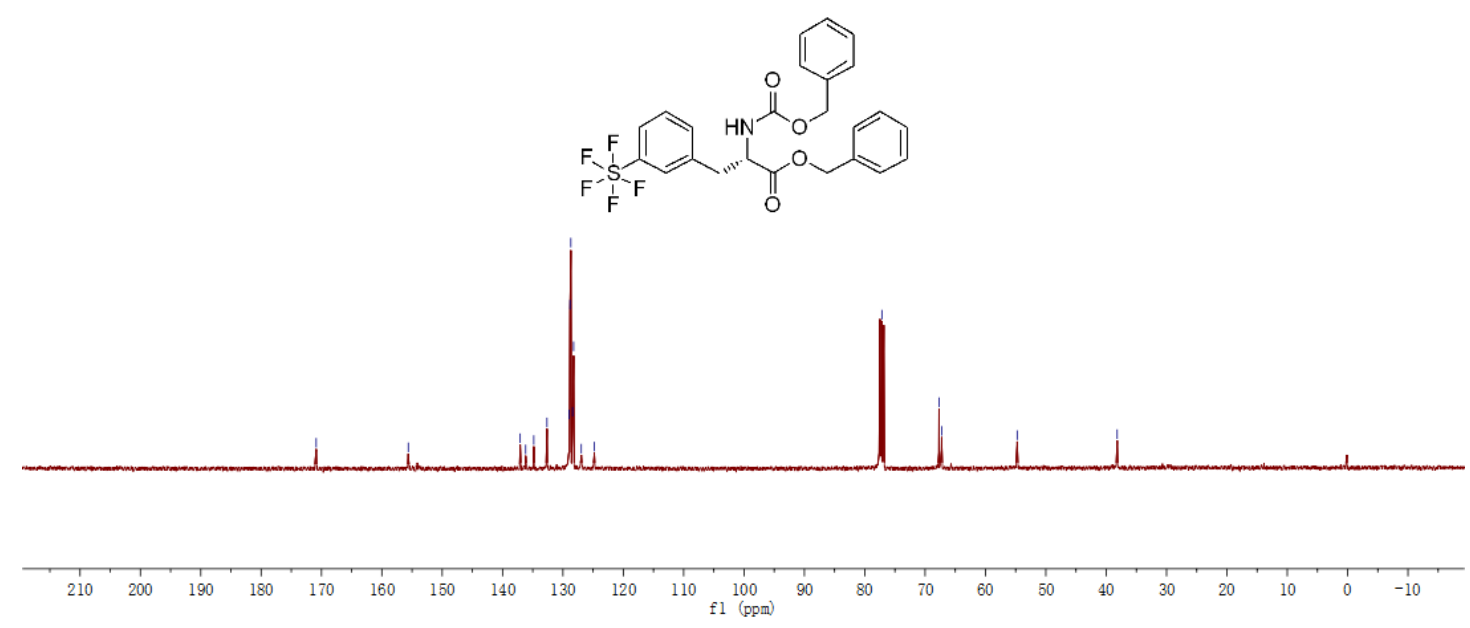

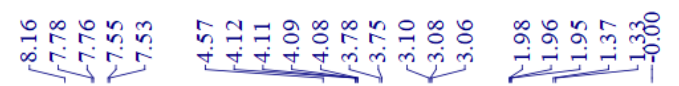
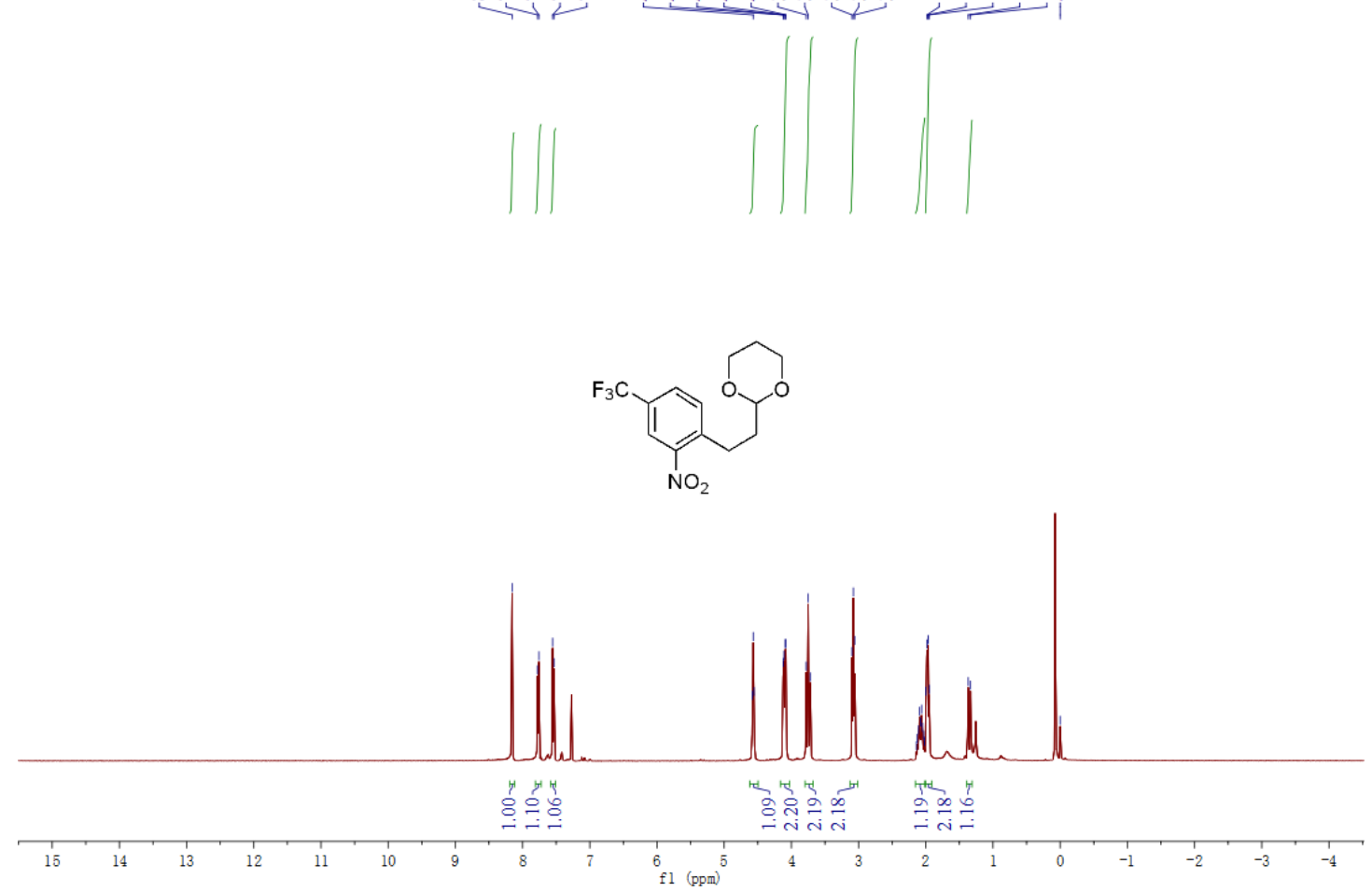


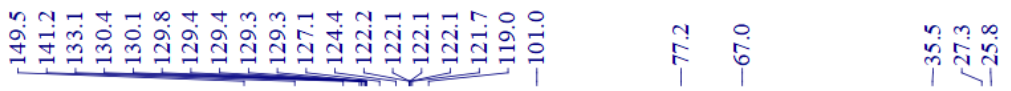

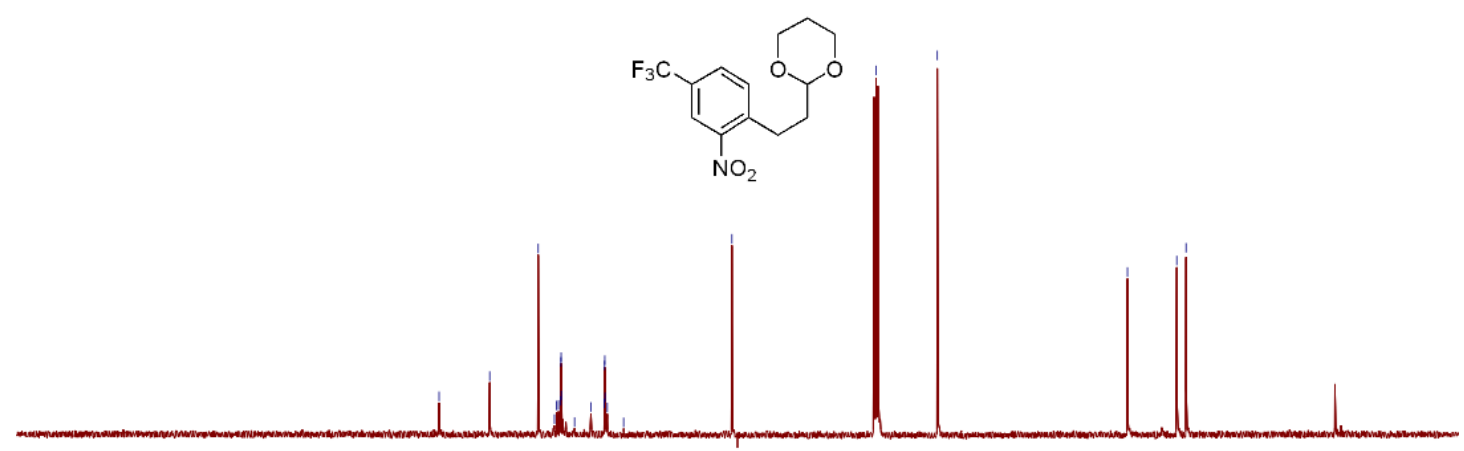

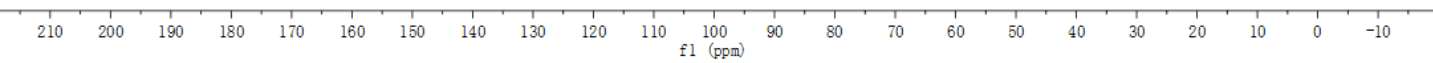

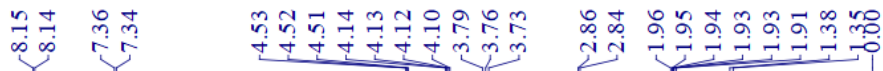

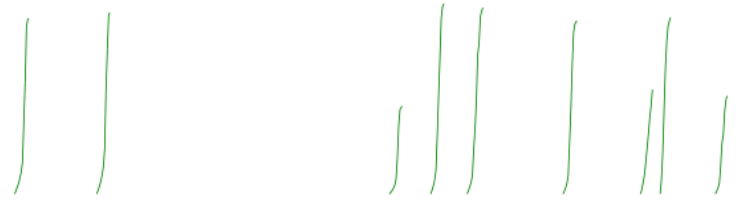

$\mathrm{O}_{2} \mathrm{~N}$

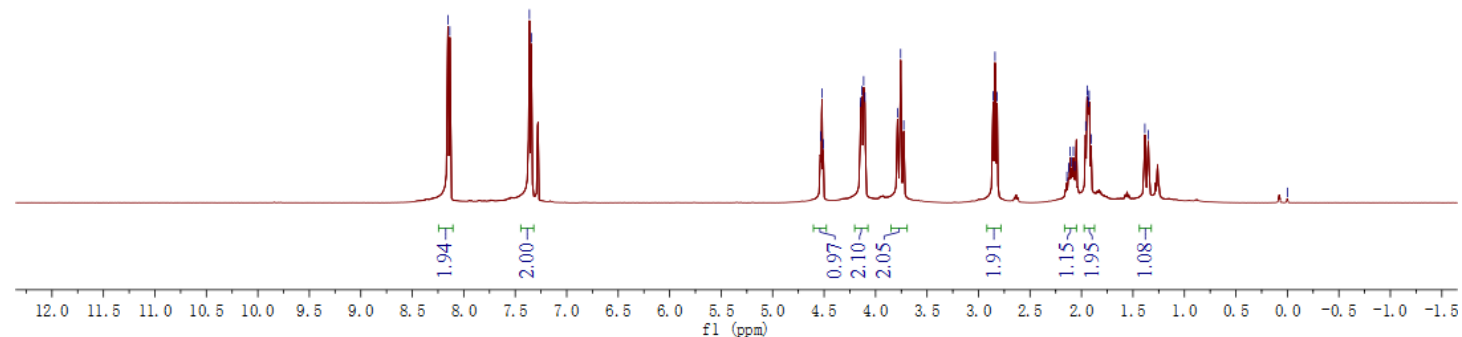




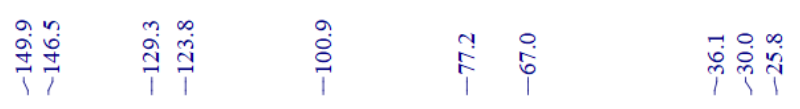
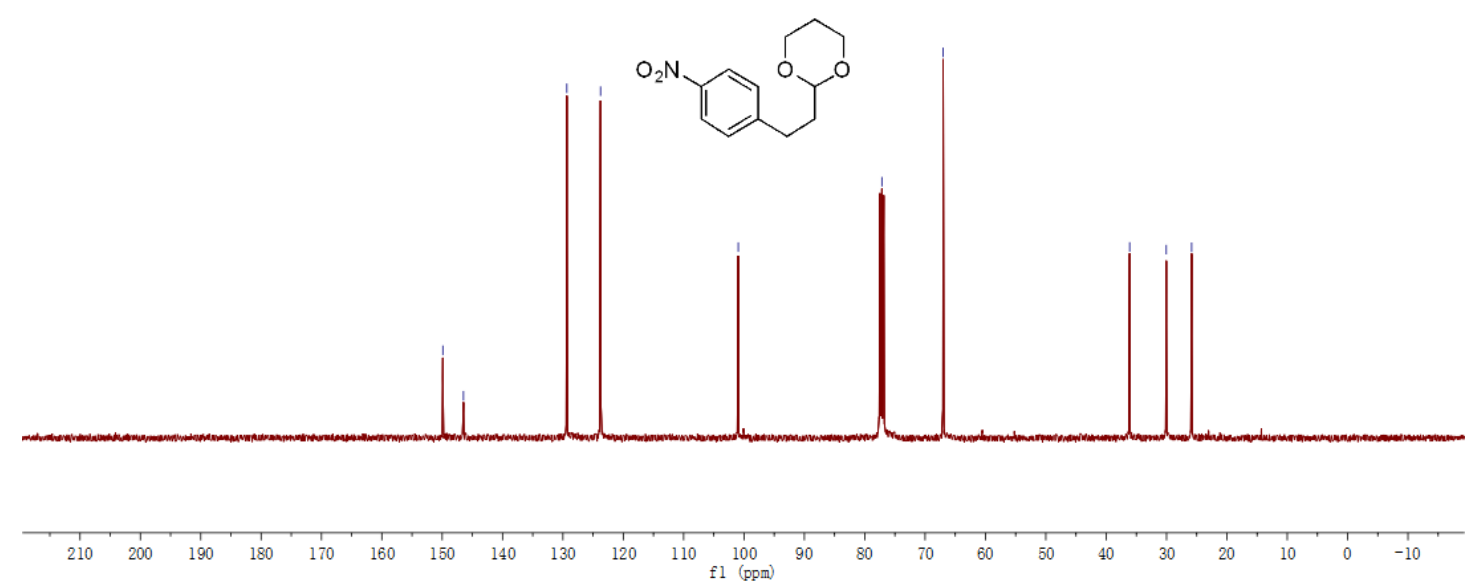

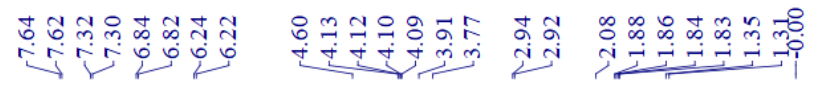
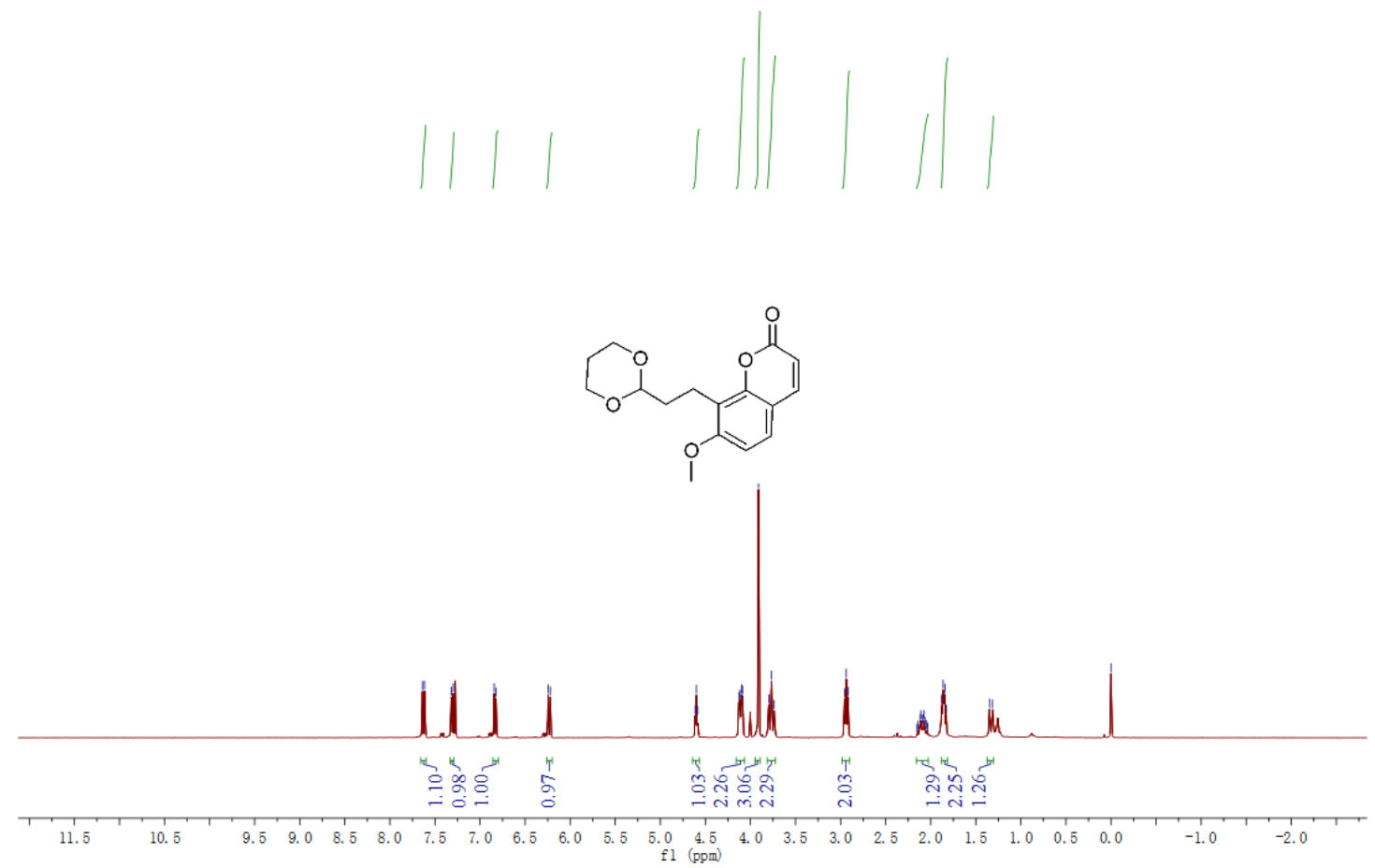


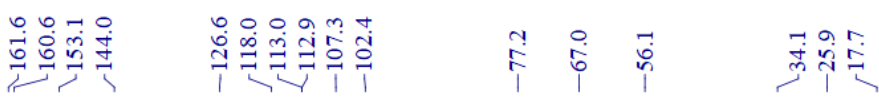
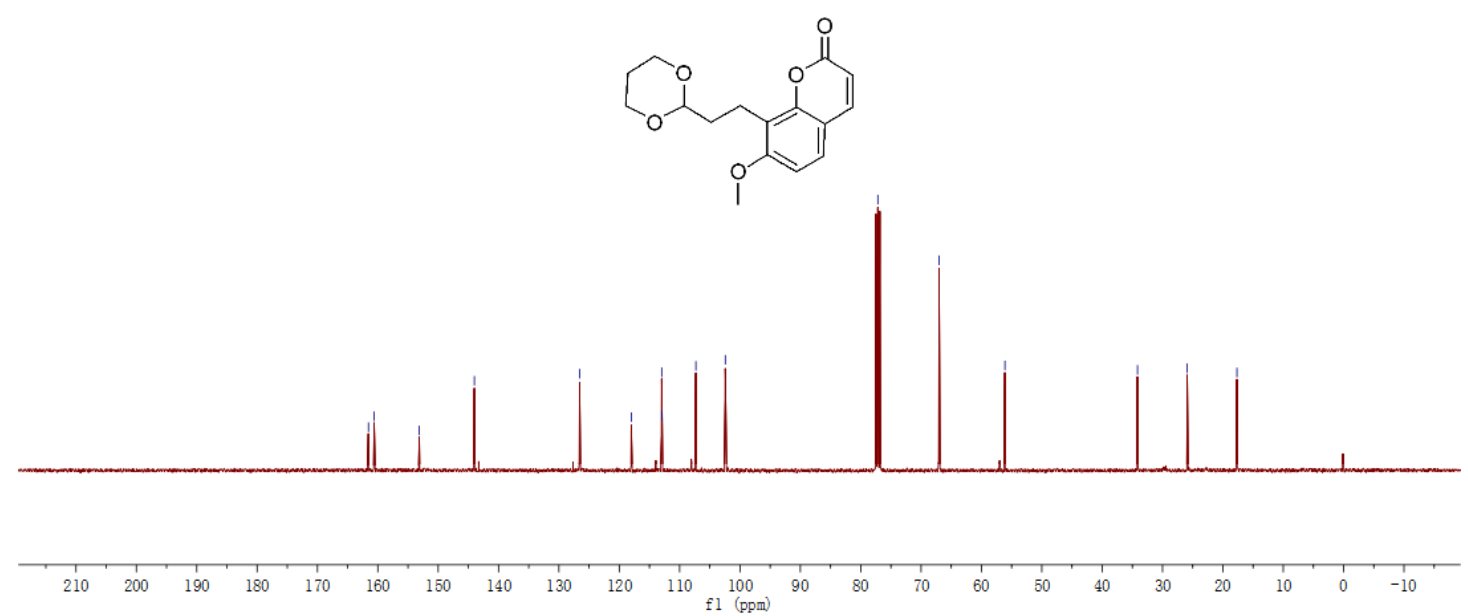

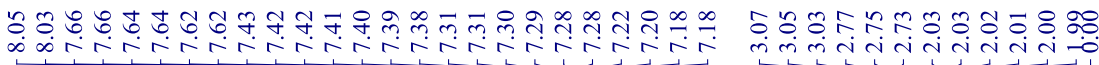
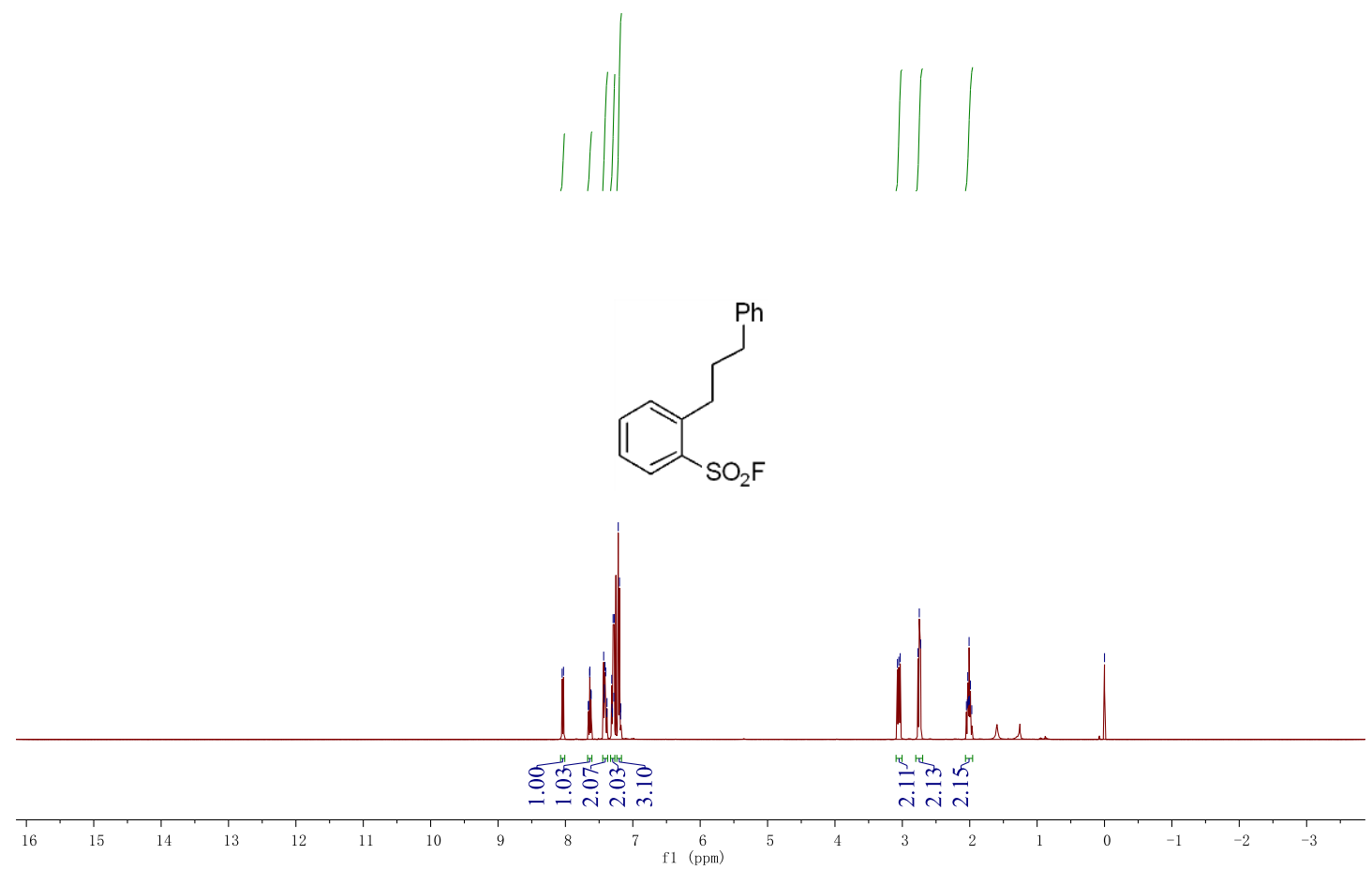


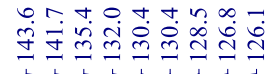

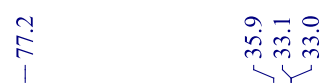

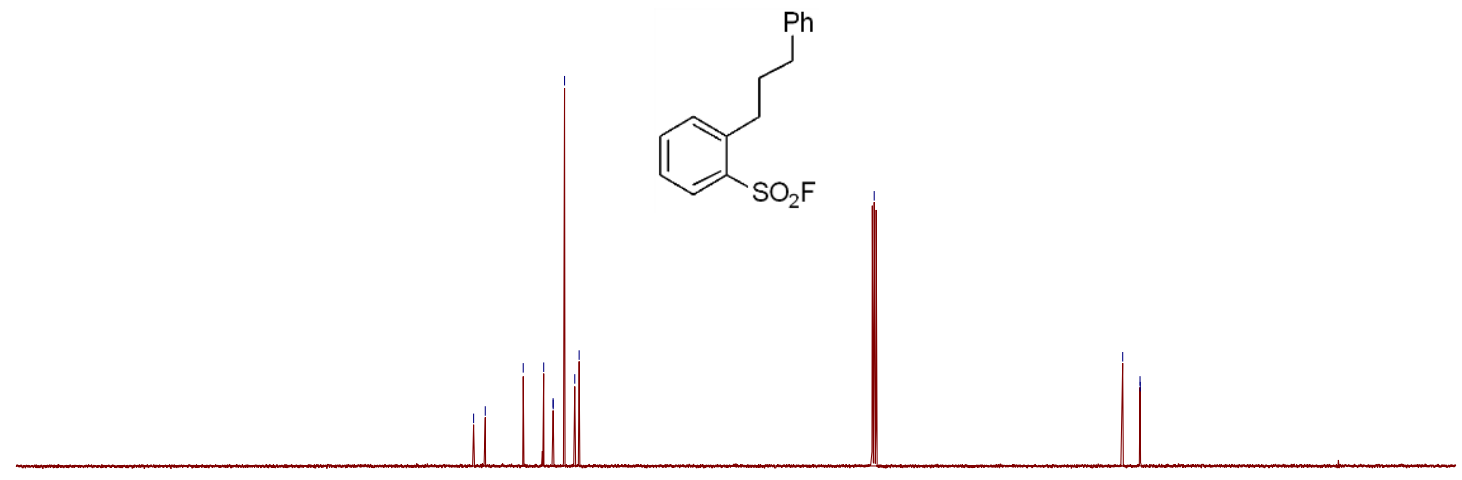

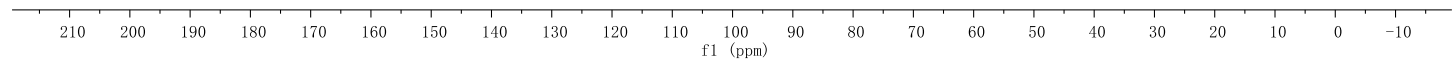

$\stackrel{\circ}{\dot{0}} \dot{i}$

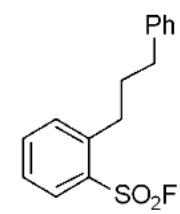

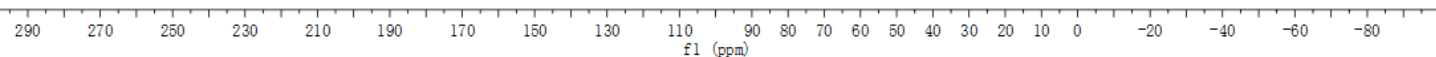




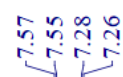

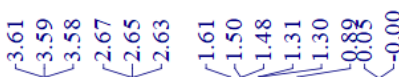

$1\left|\int\right||| \mid$

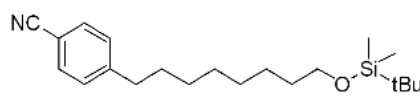

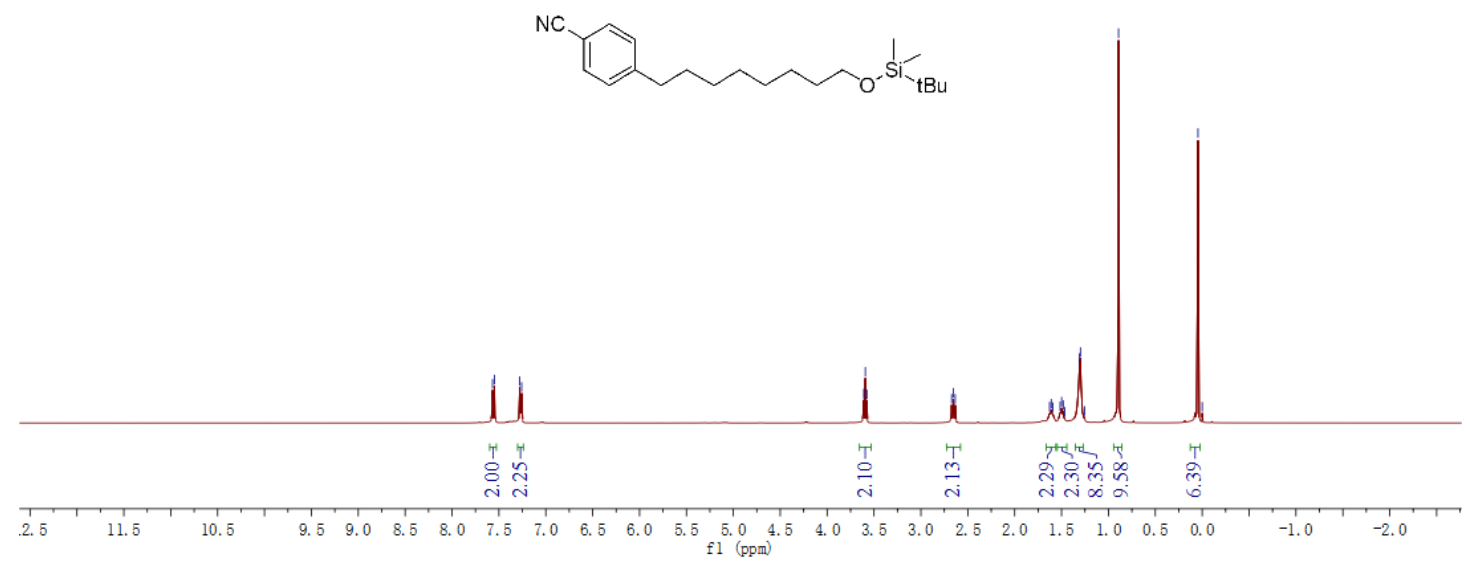

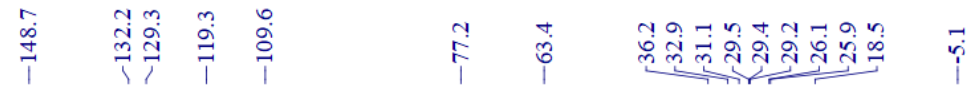

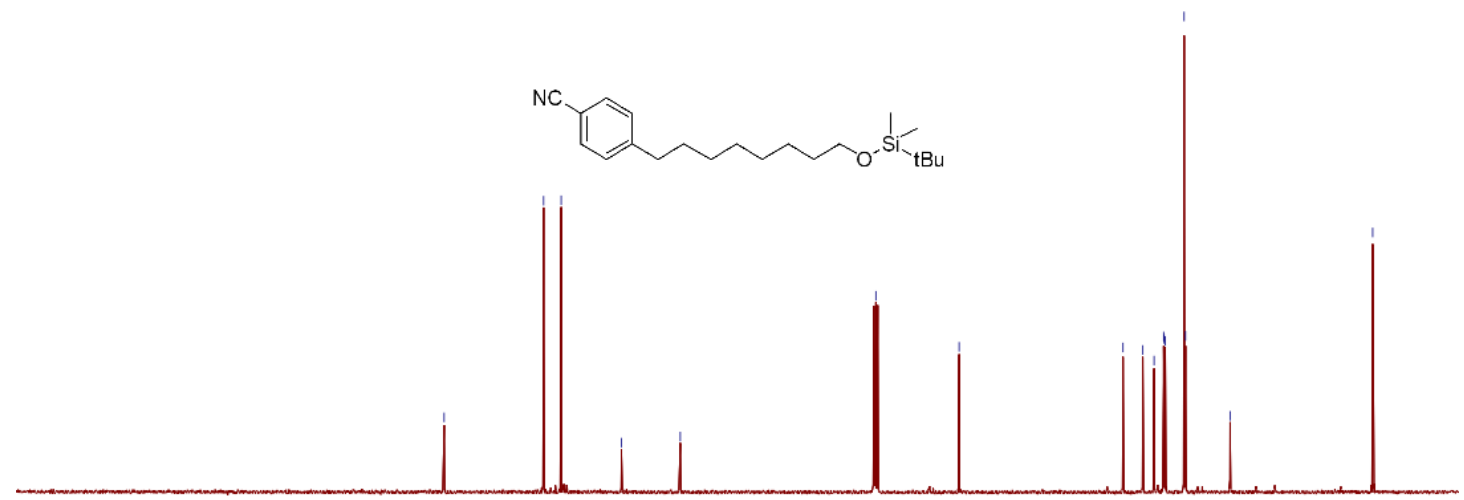

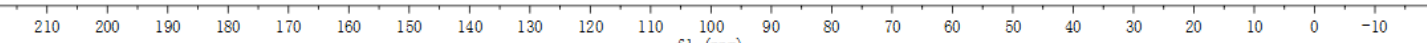




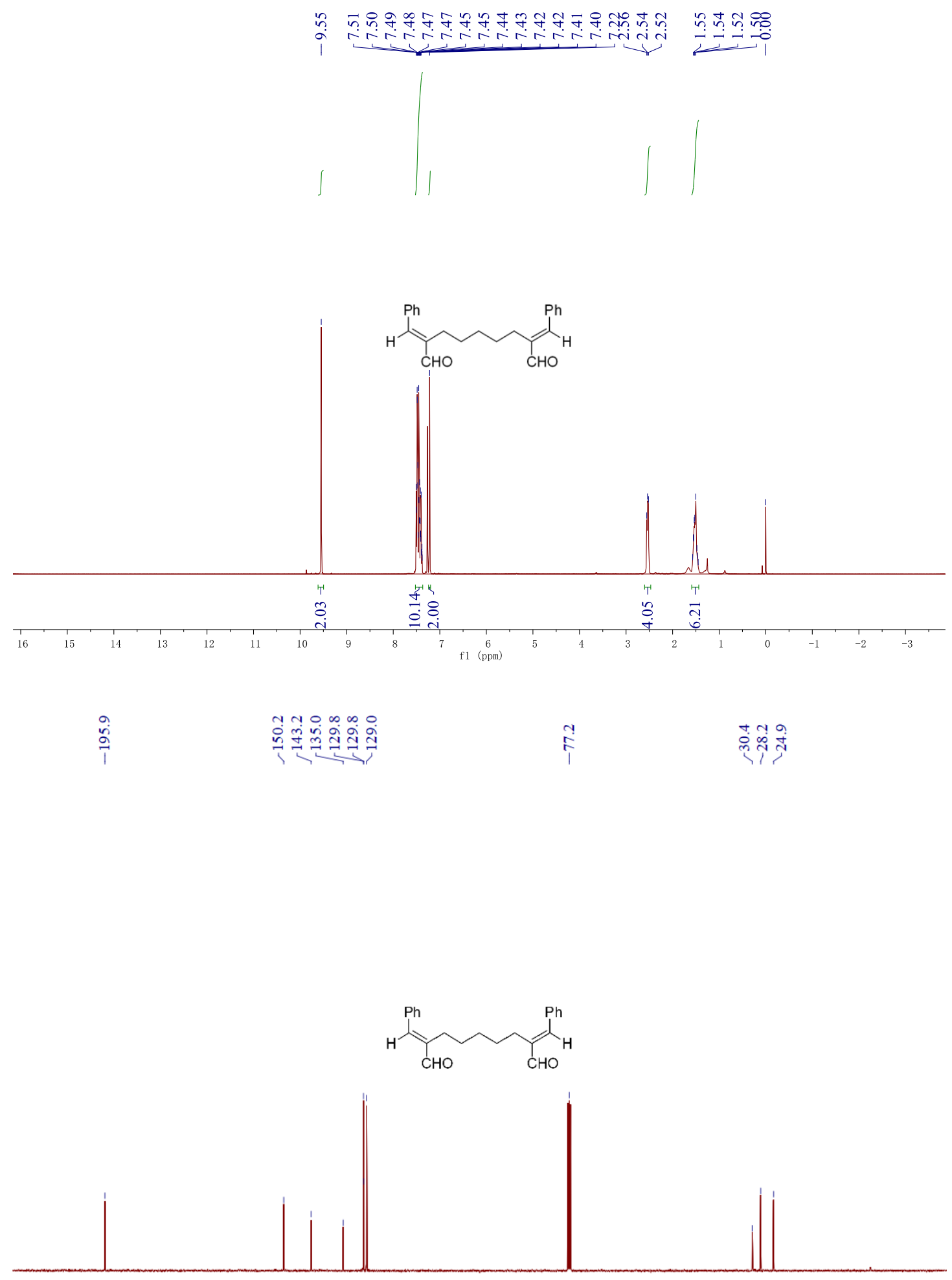

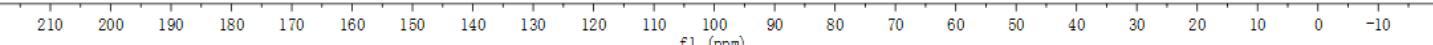




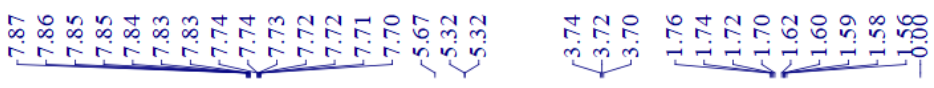
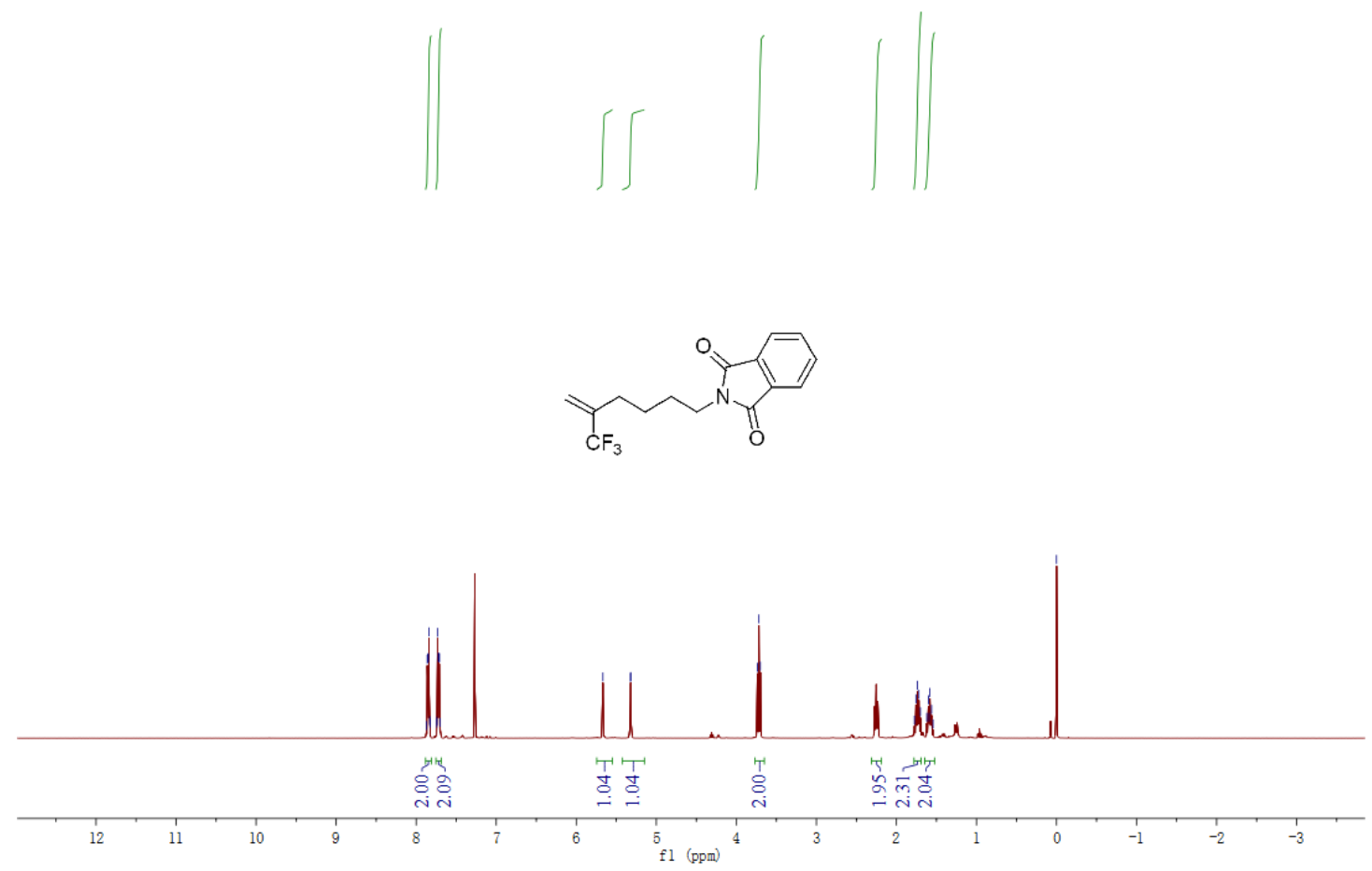

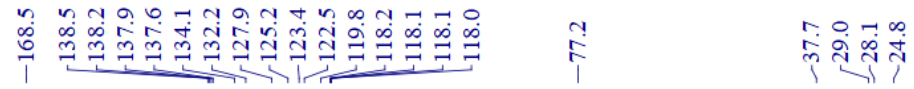
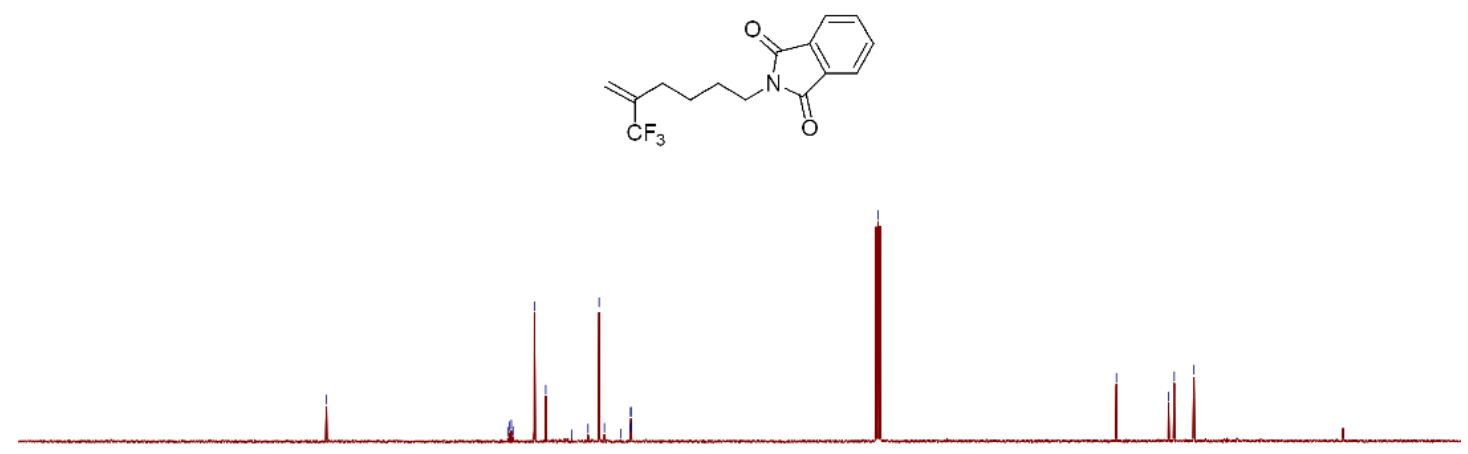

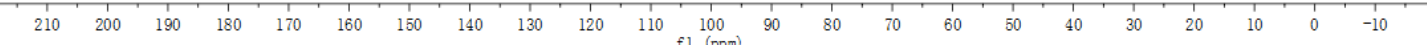



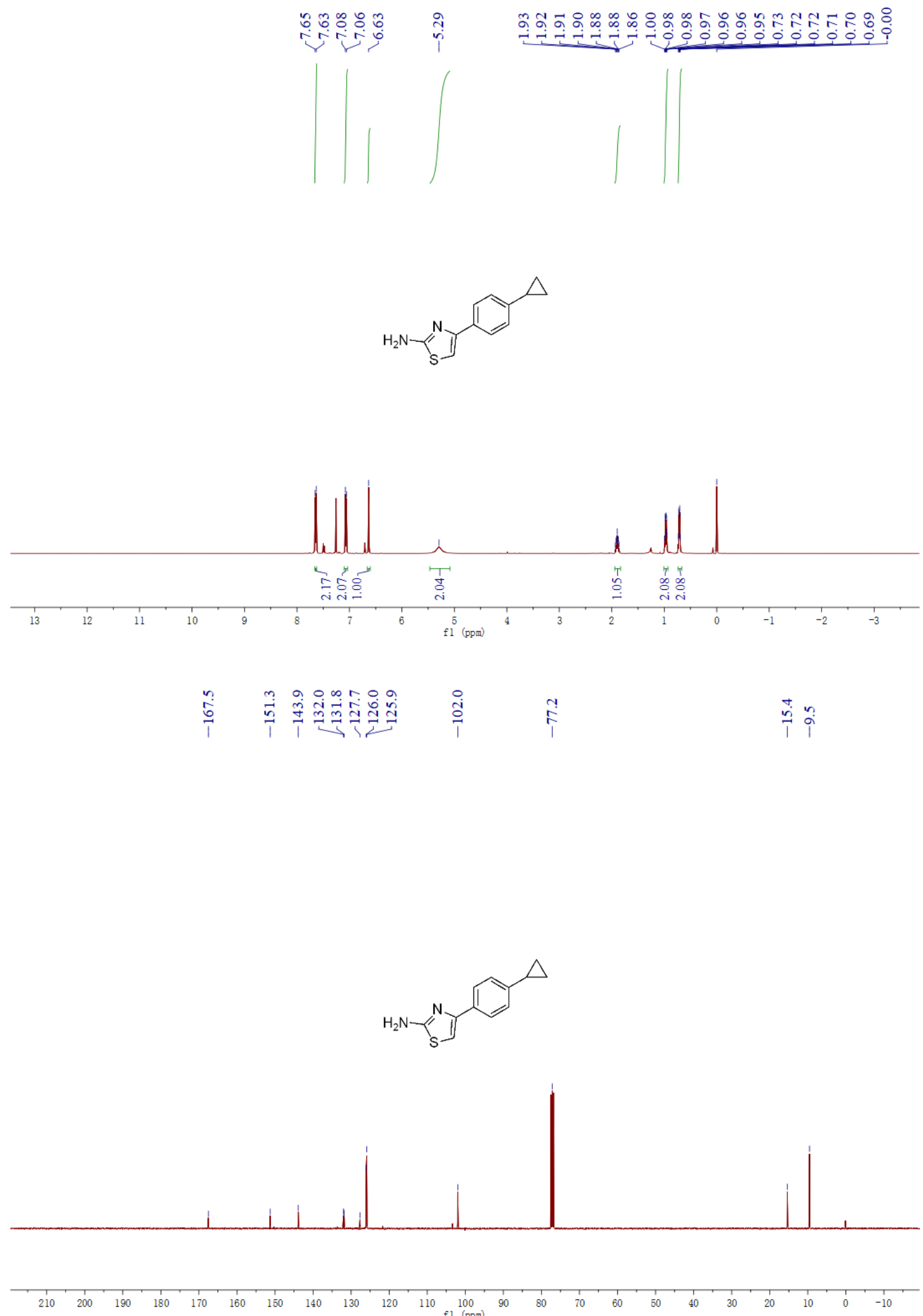

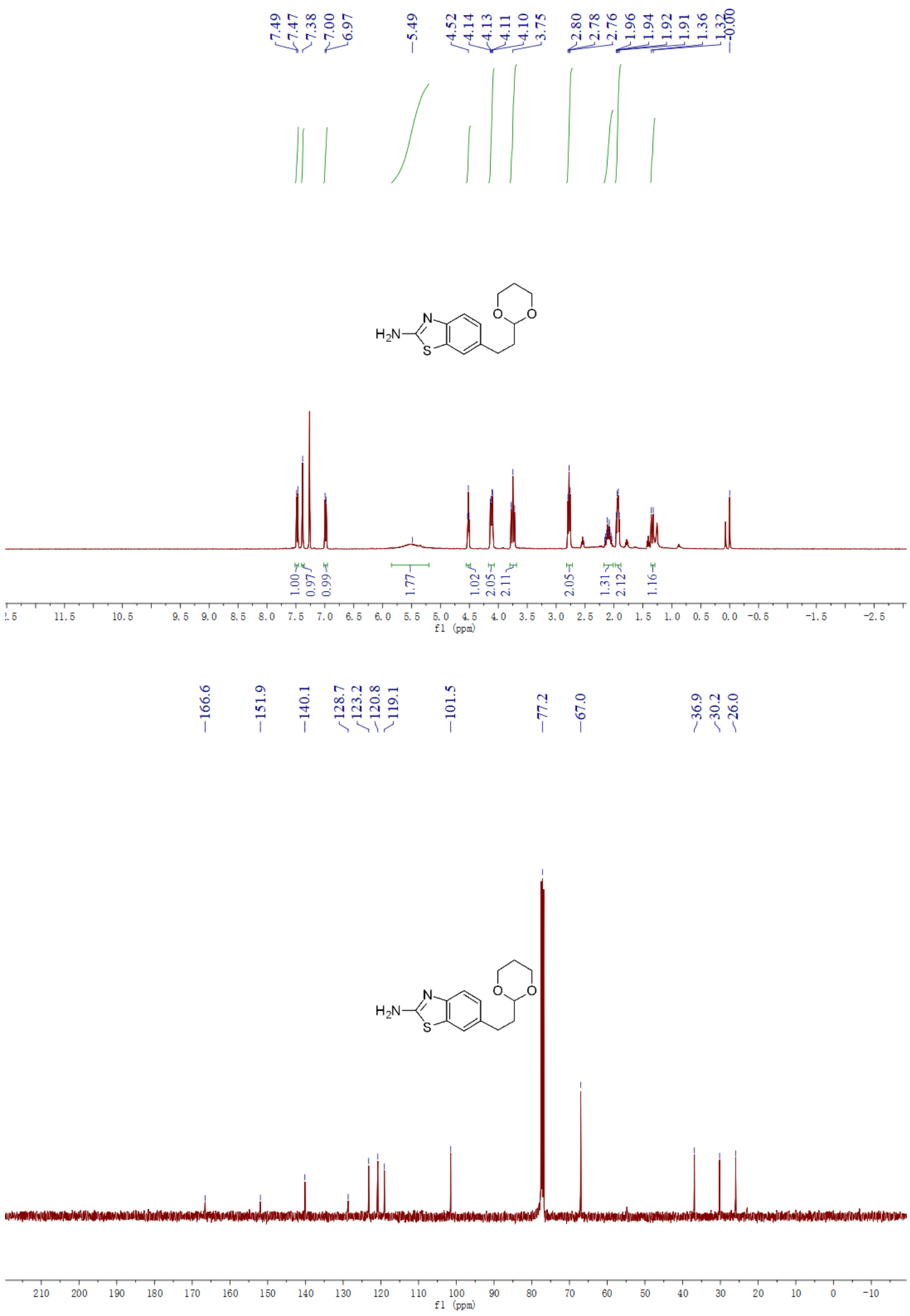

S116 


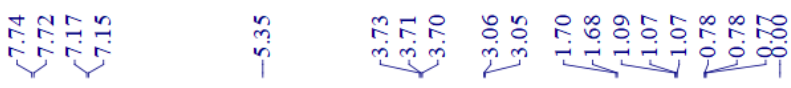

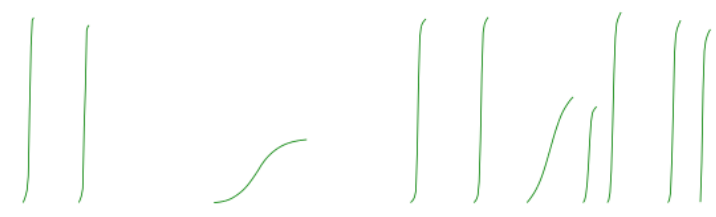

(1)

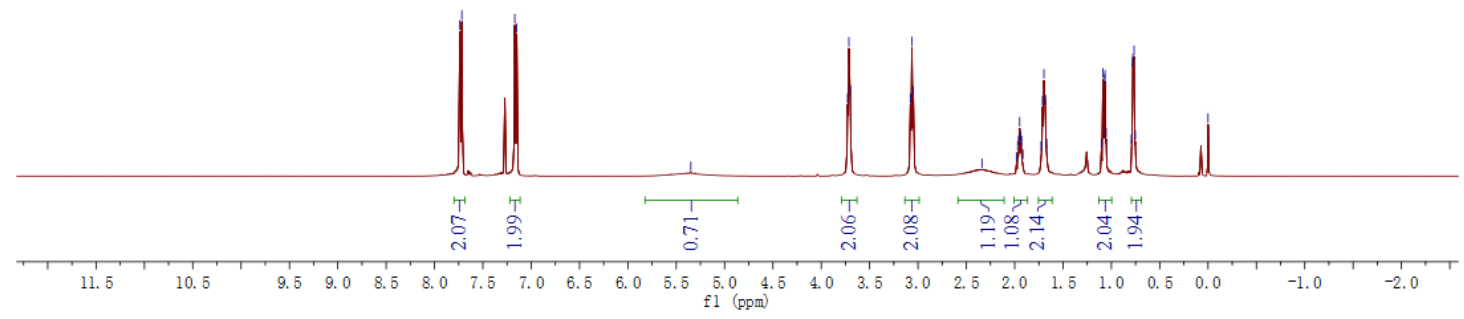

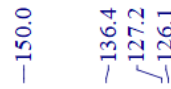

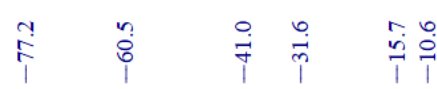
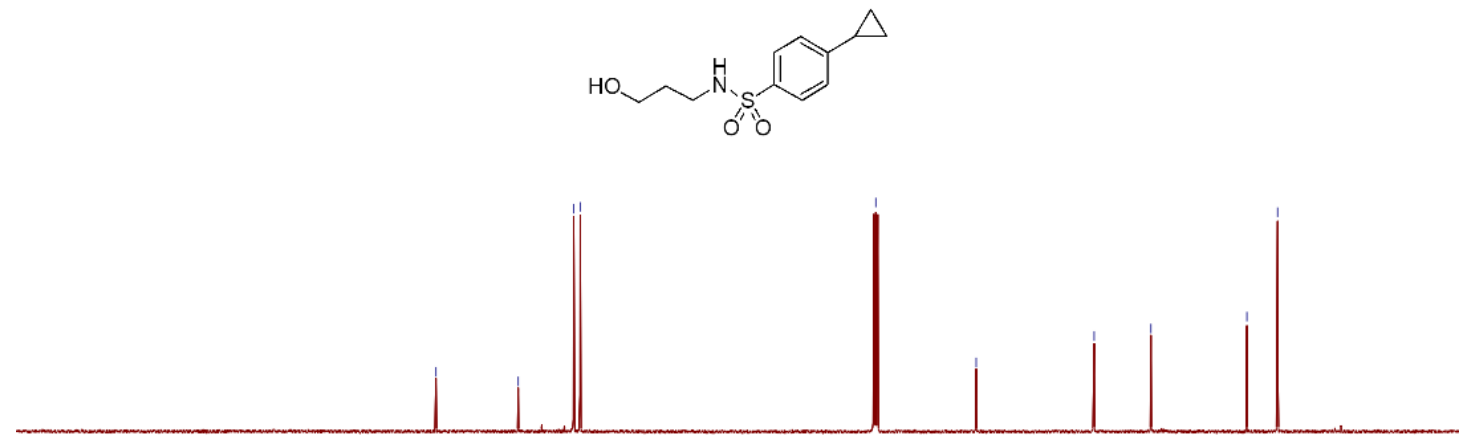

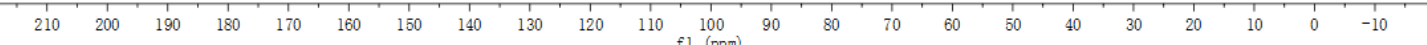




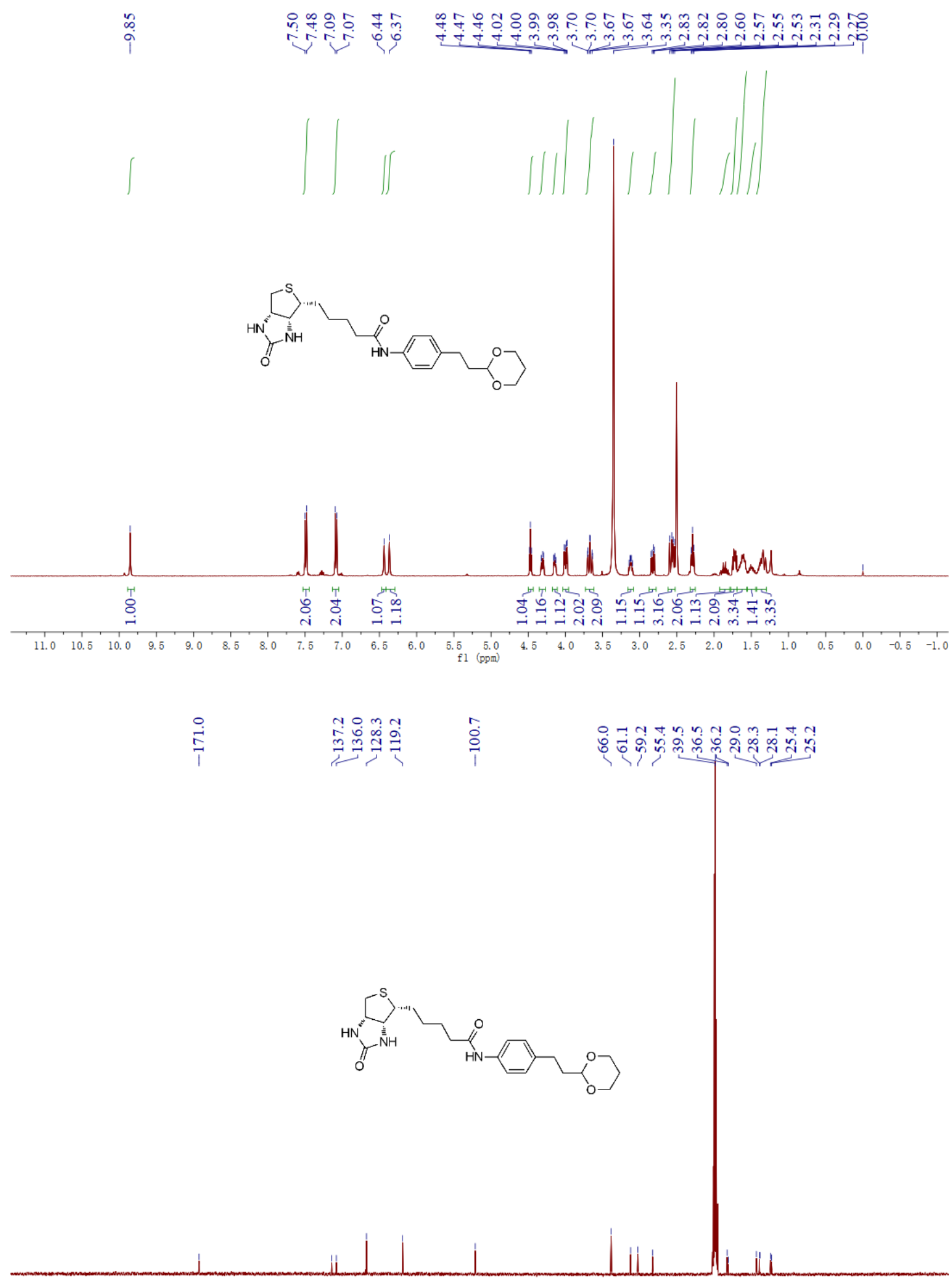

$\begin{array}{llllllllllllllllllllllllllllllllllllll}210 & 200 & 190 & 180 & 170 & 160 & 150 & 140 & 130 & 120 & 110 & 100 & 90 & 80 & 70 & 60 & 50 & 40 & 30 & 20 & 10 & 0 & -10\end{array}$ 


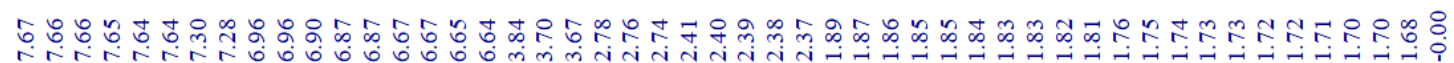

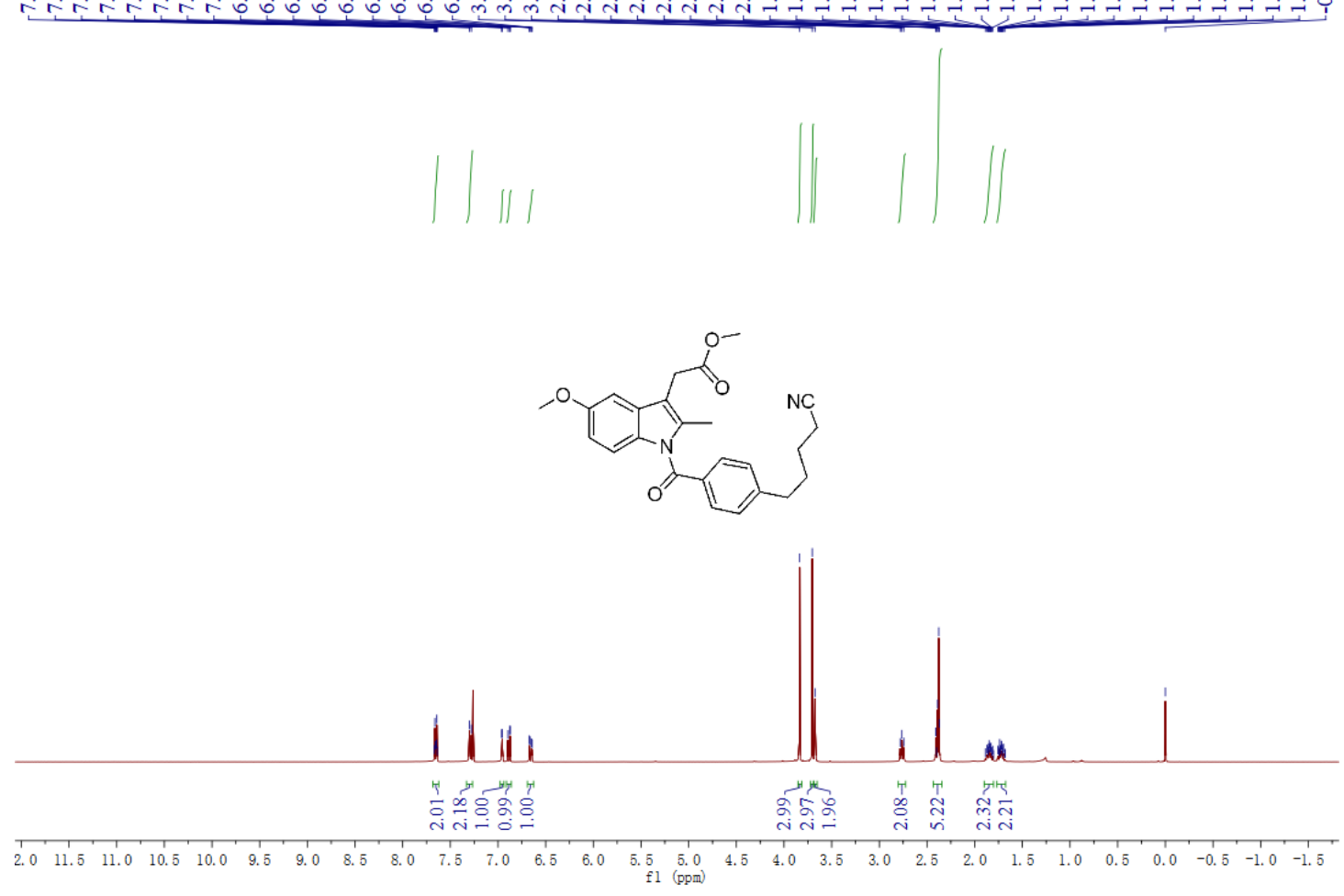

管

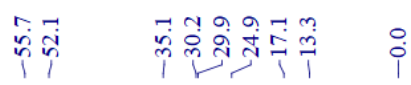

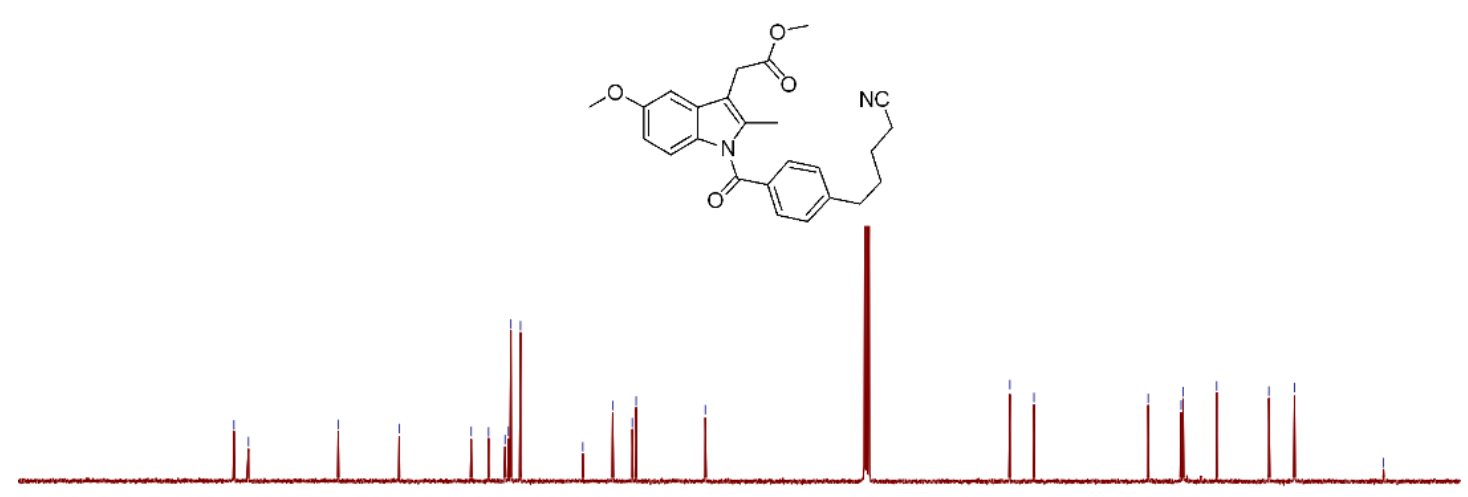

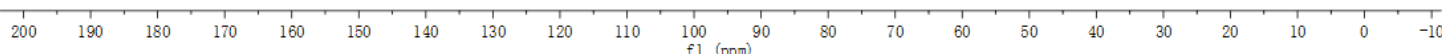




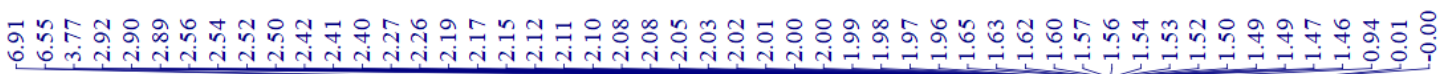

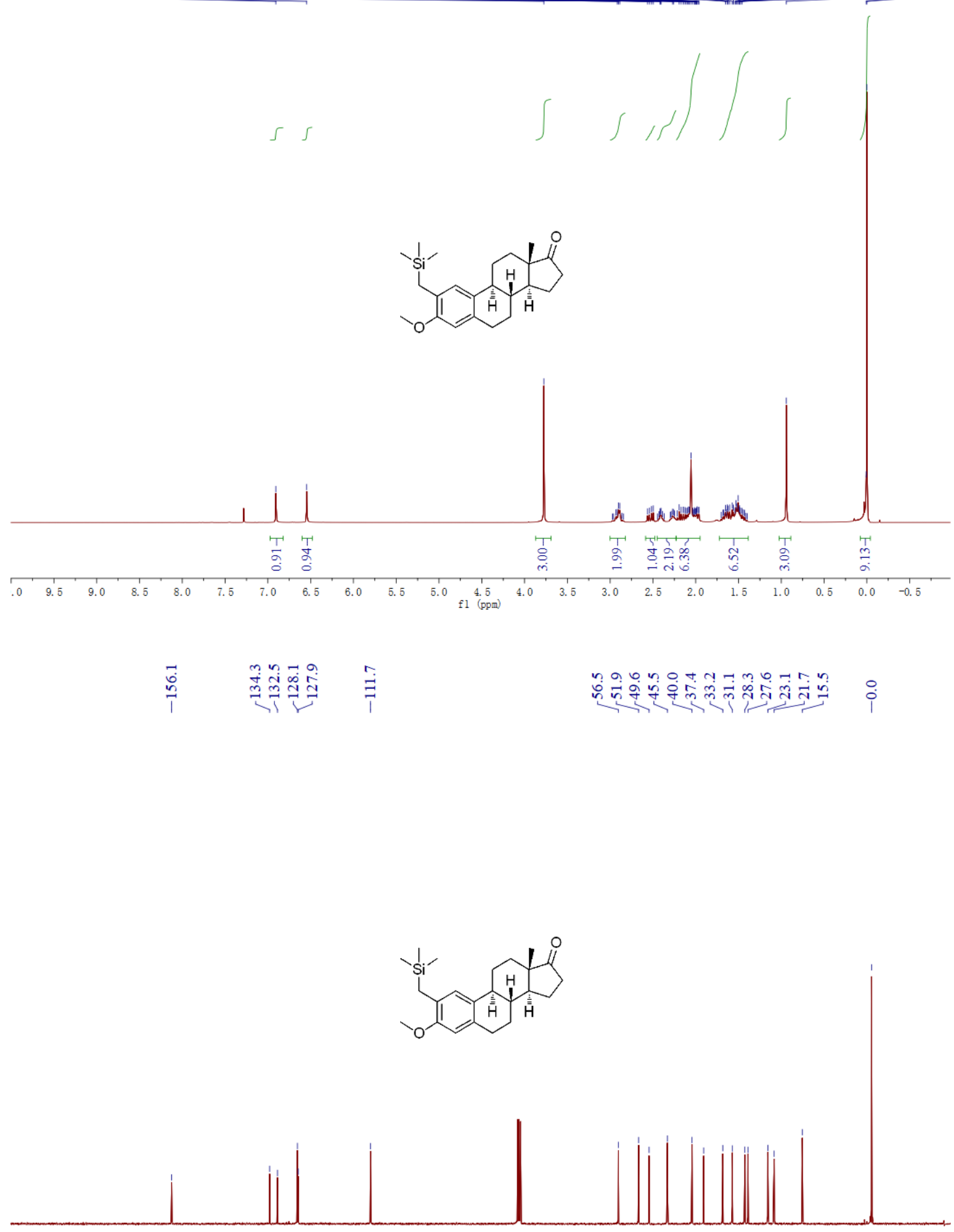

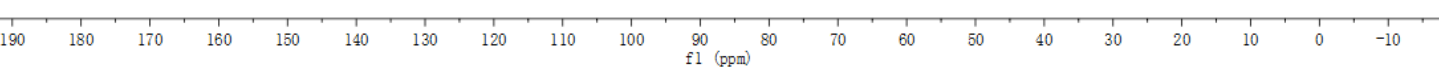




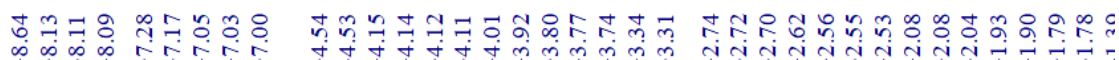

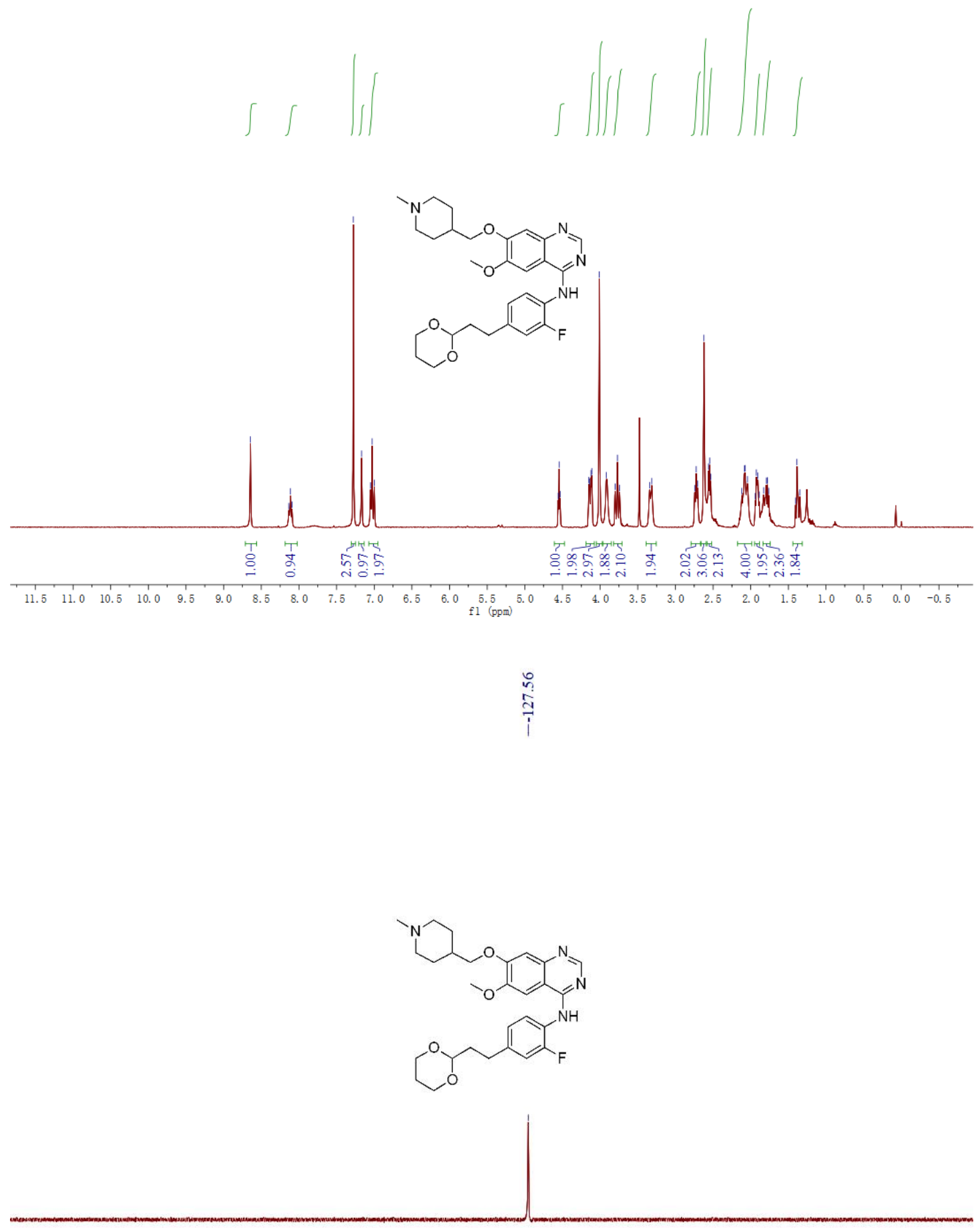

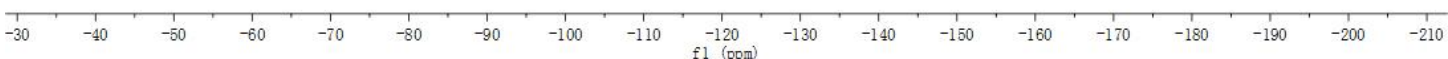




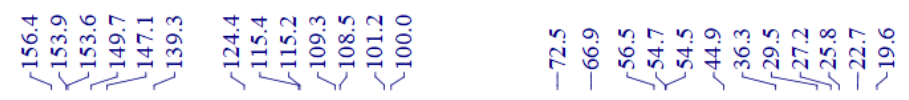
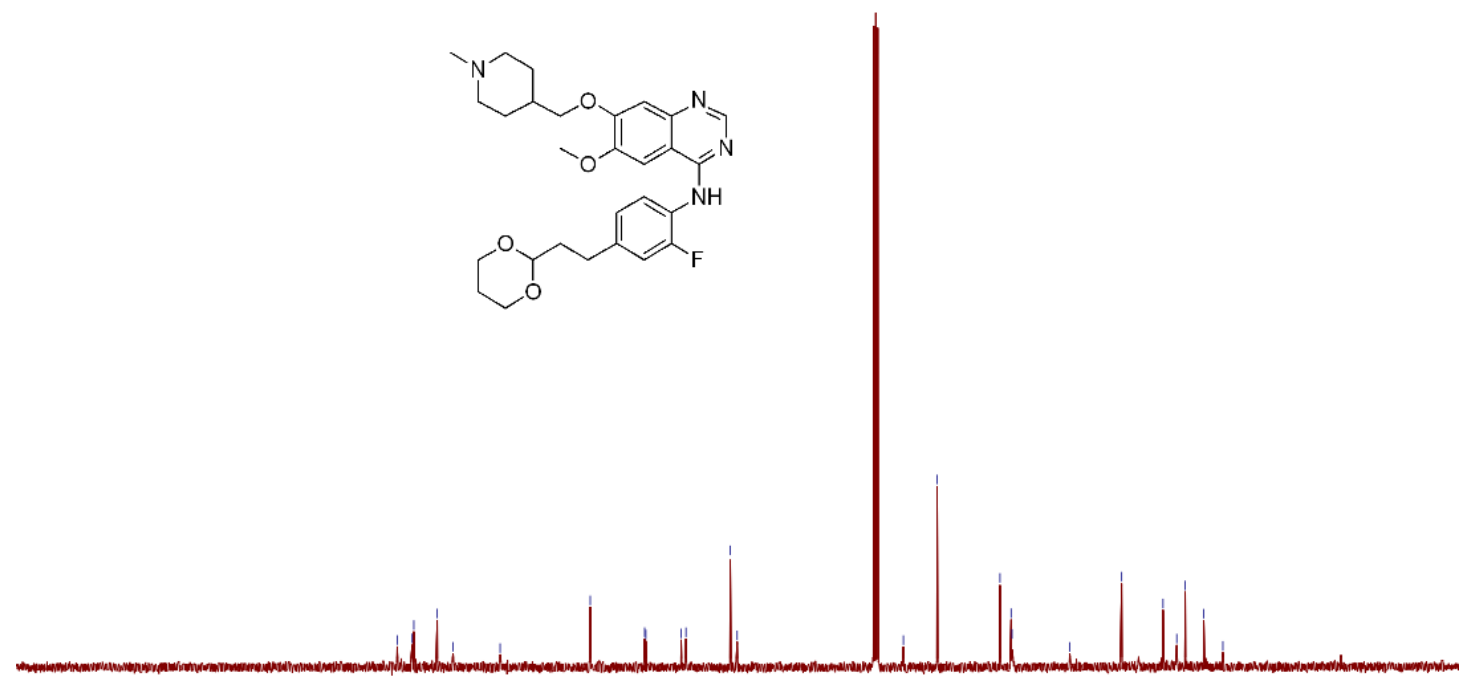

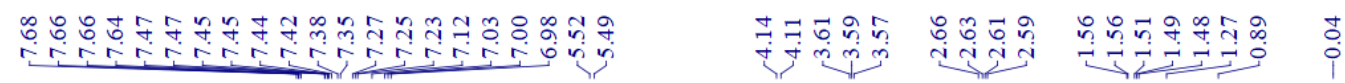

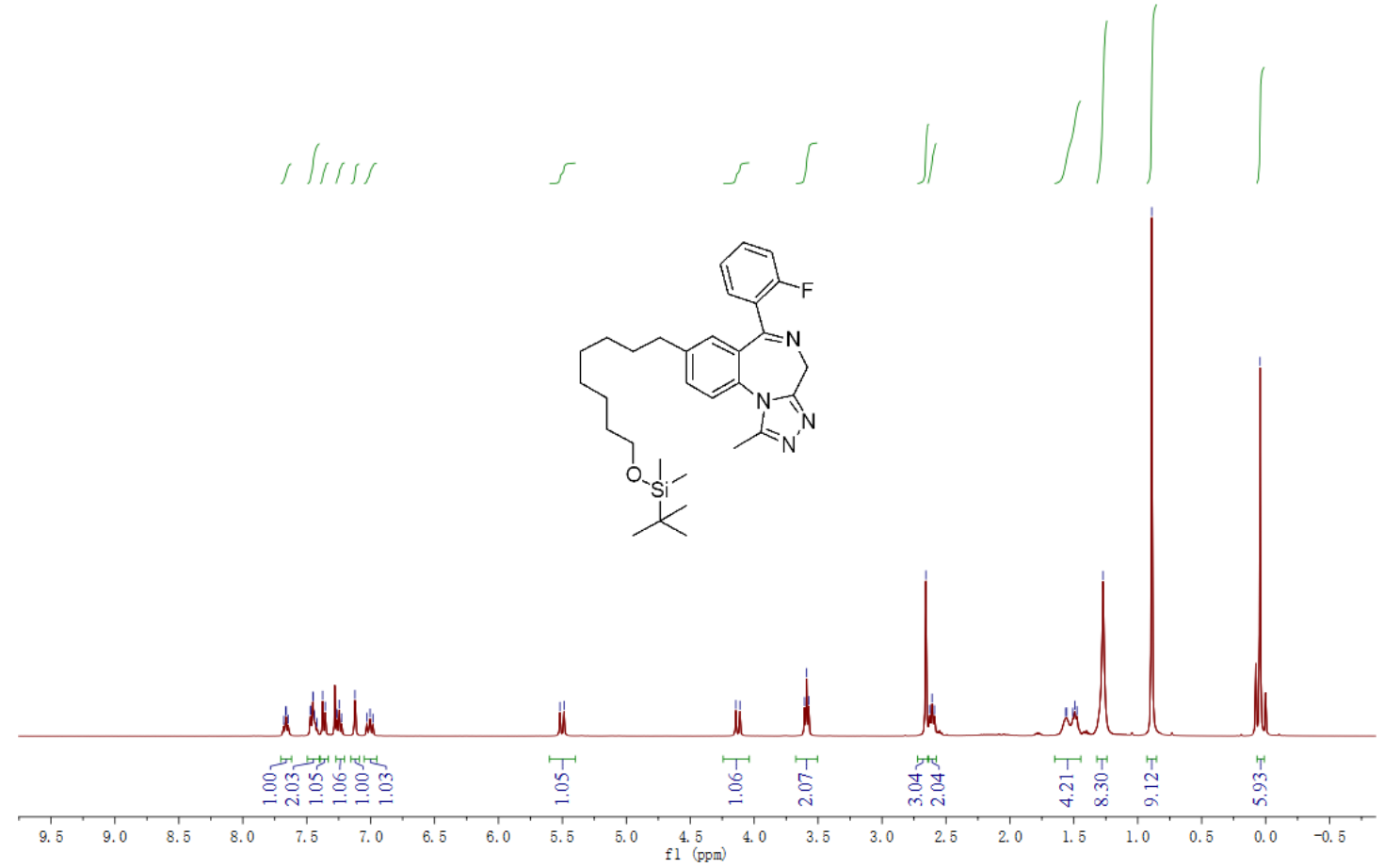




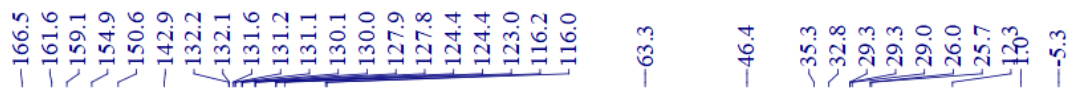

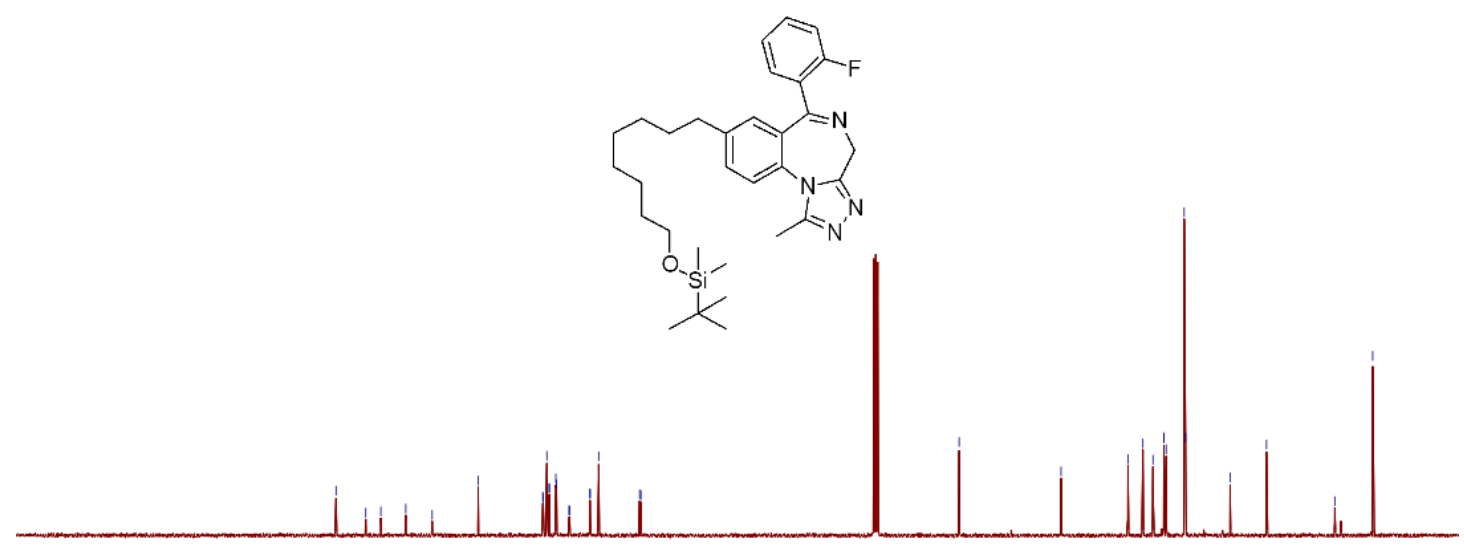

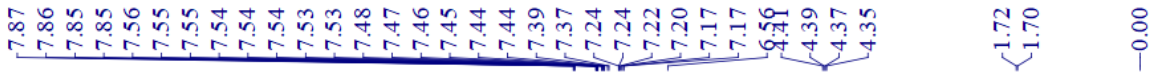

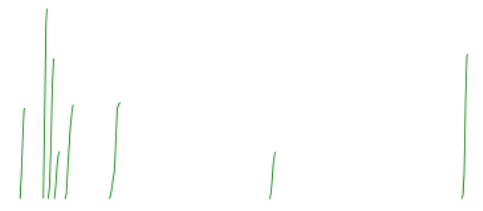

(

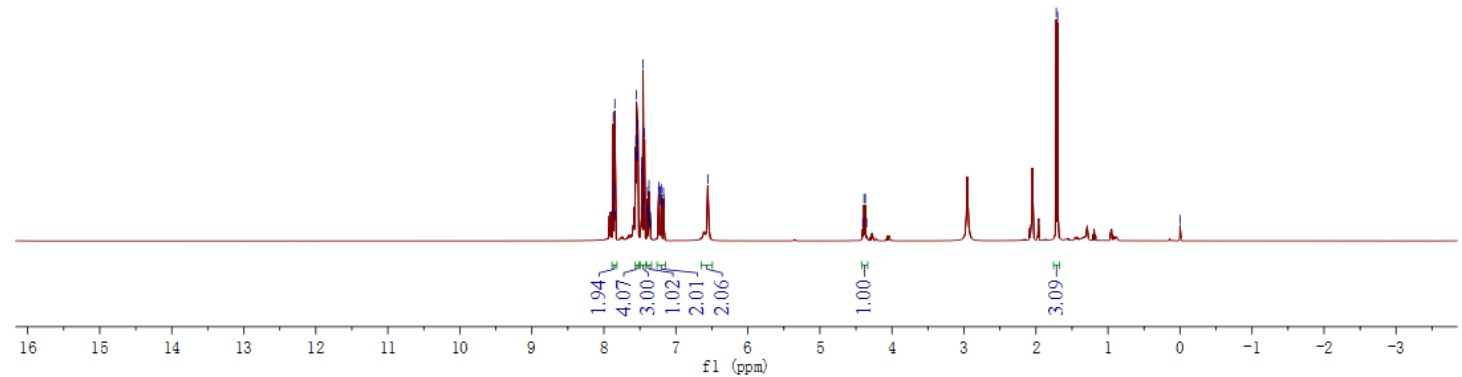




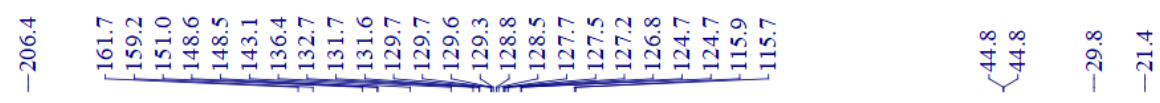
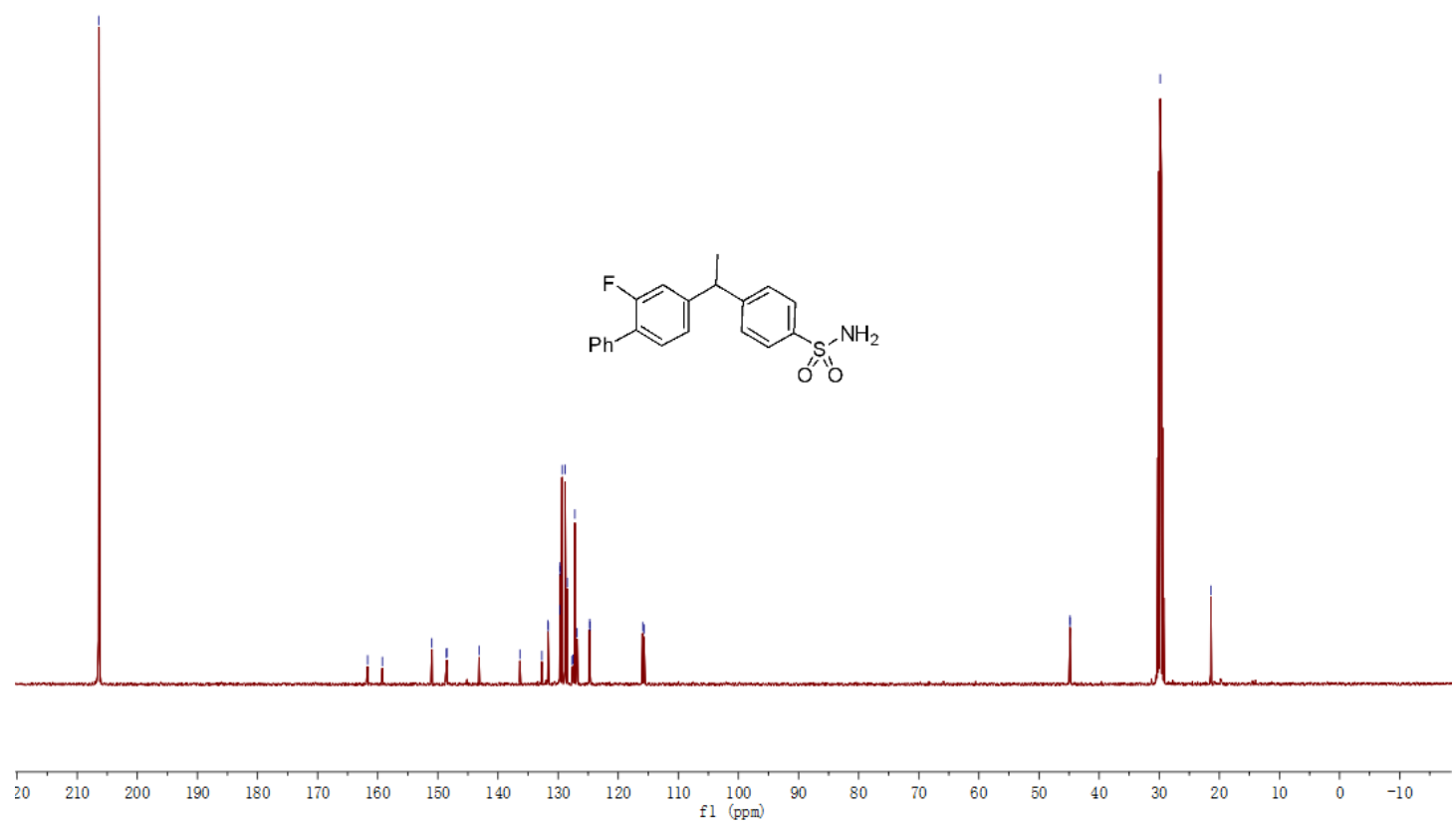

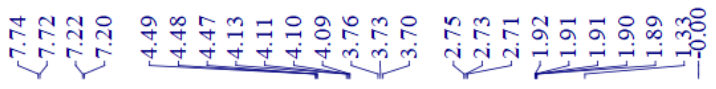

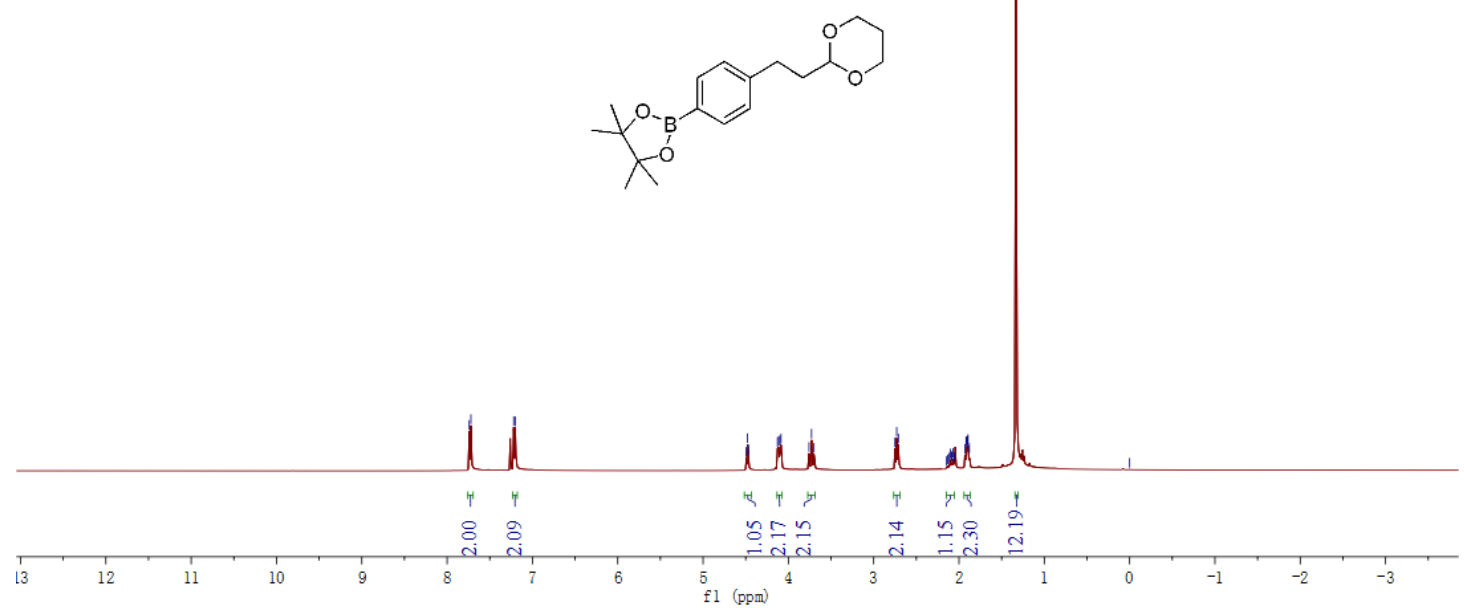


$x_{\substack{0 \\ 0^{\circ}}}^{N_{0}^{0}}$

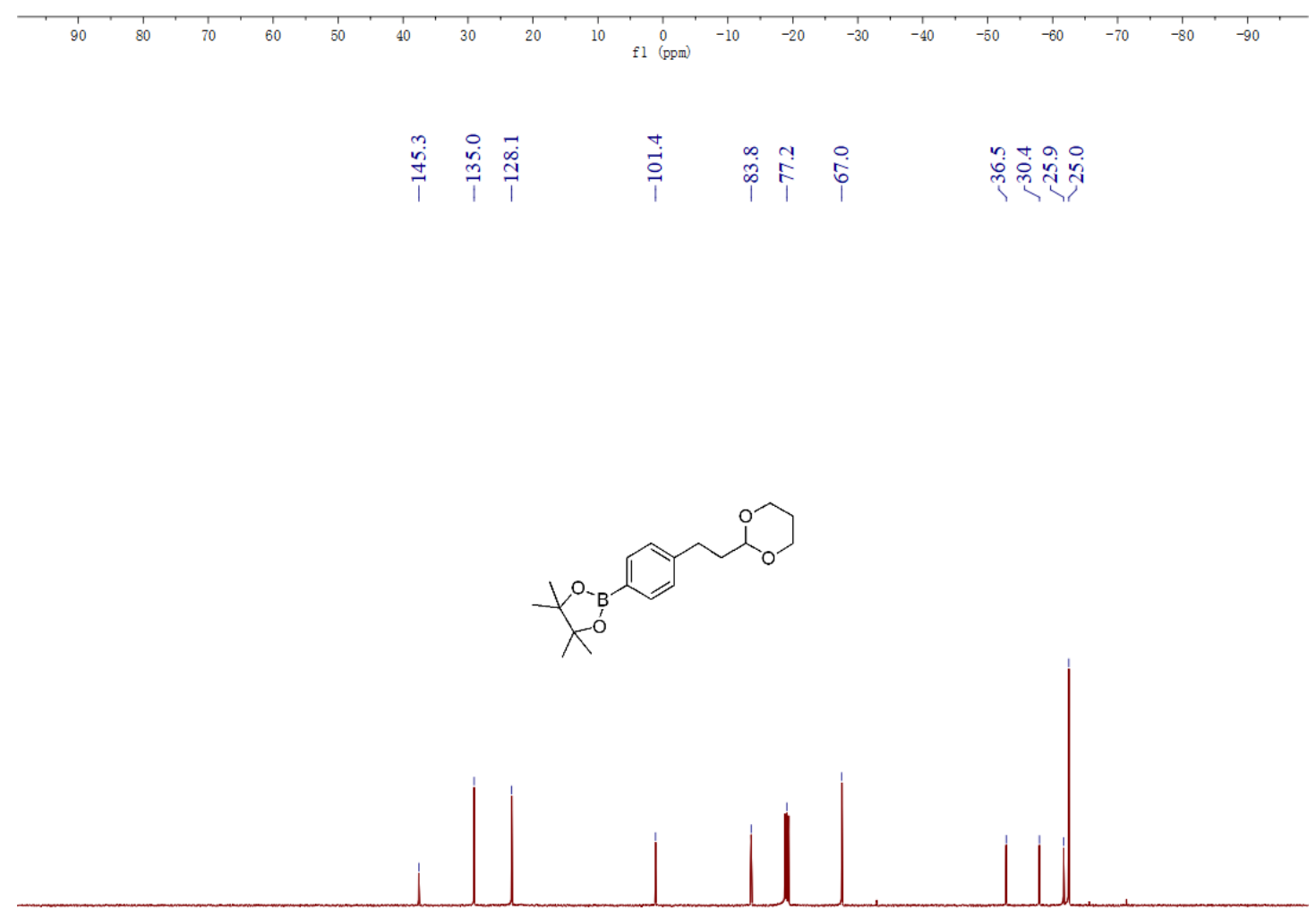

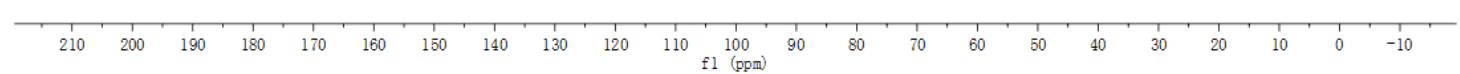



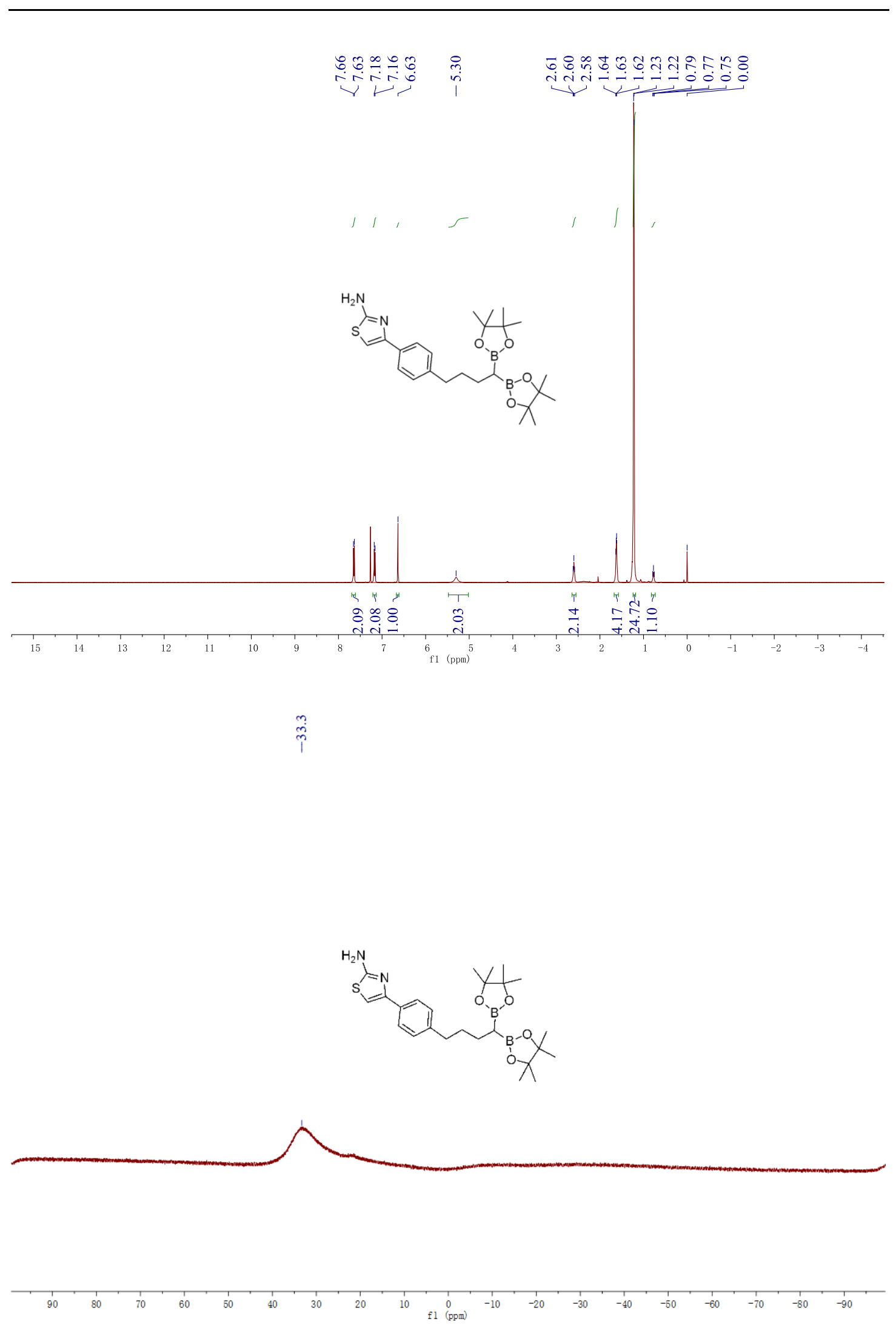

S126 


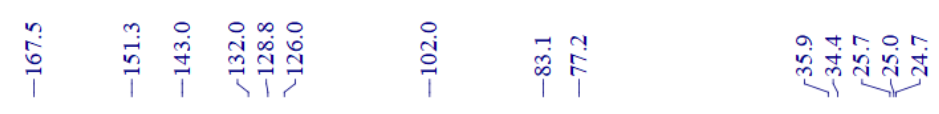
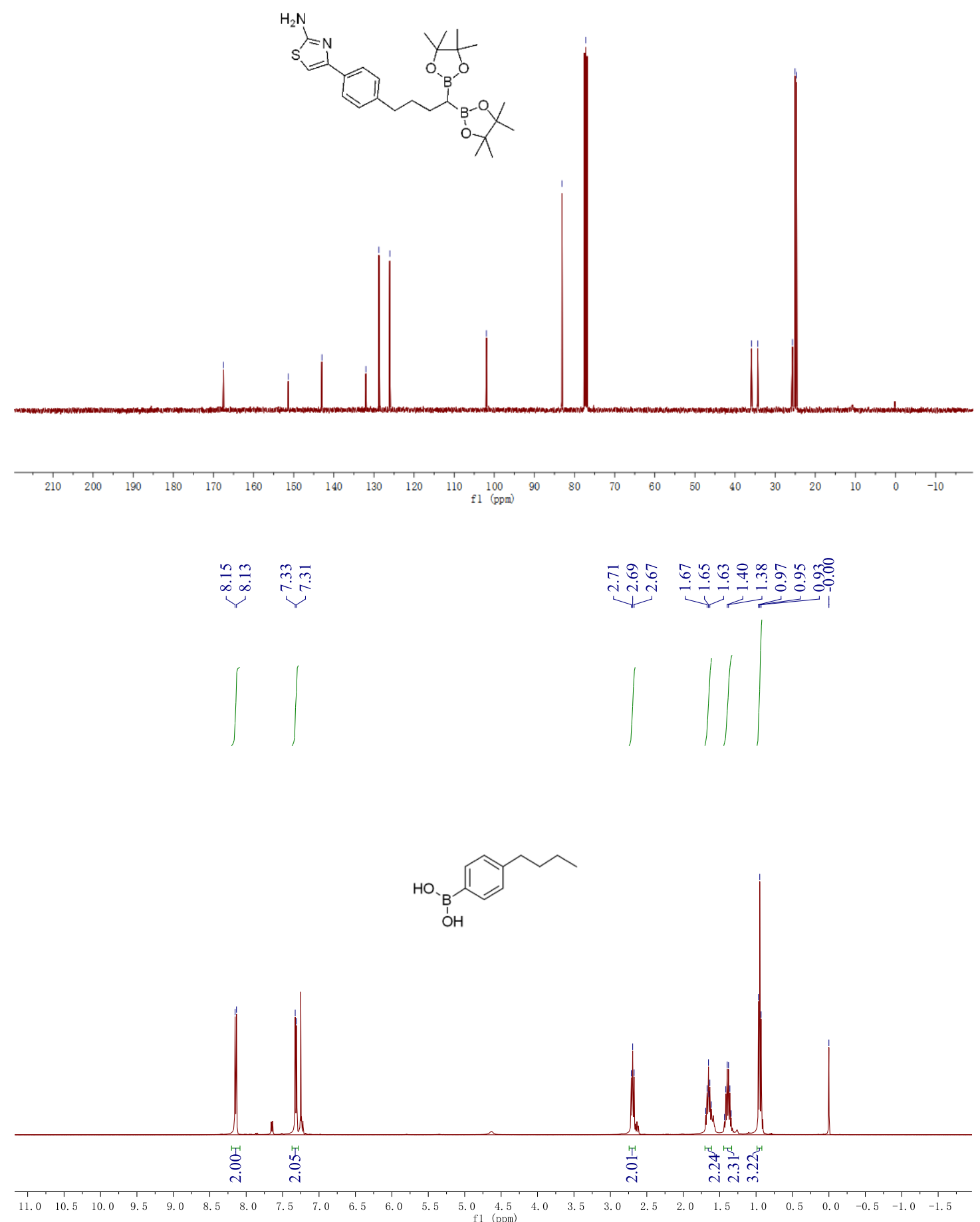


$$
\text { (1) }
$$

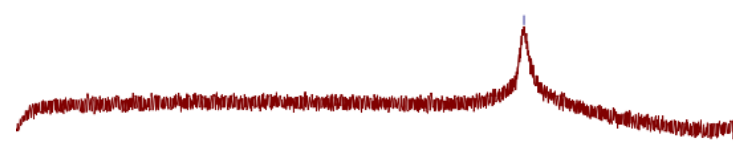

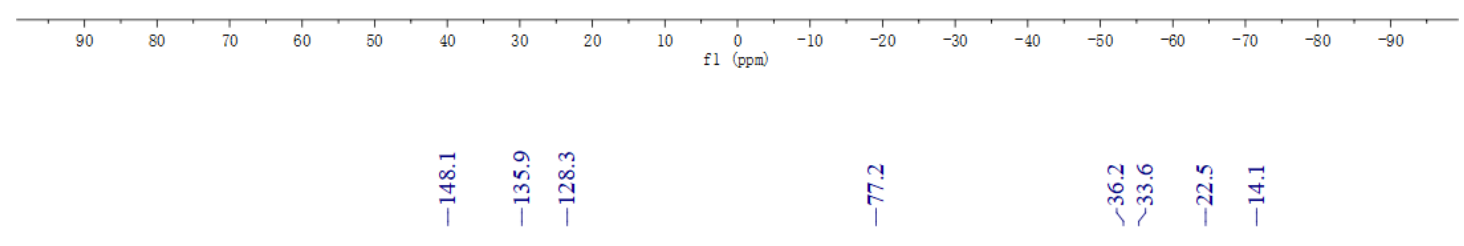

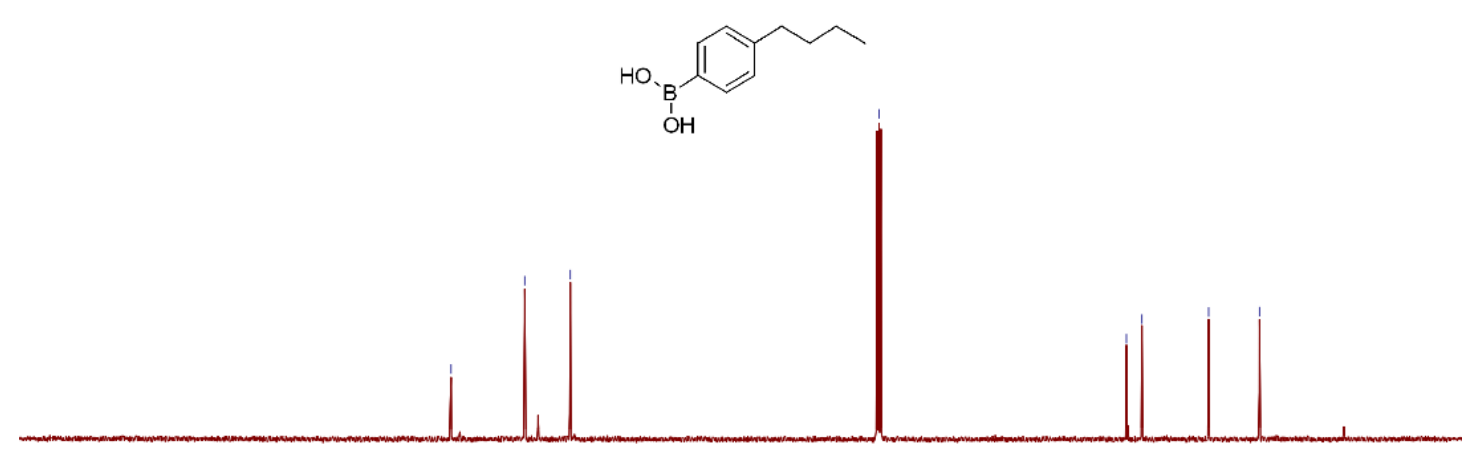

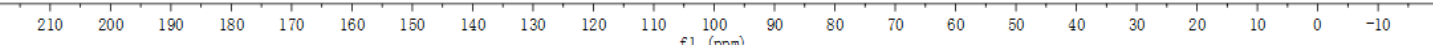




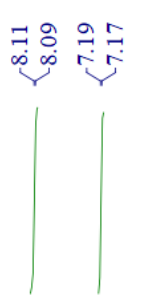

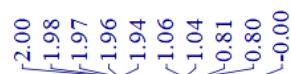
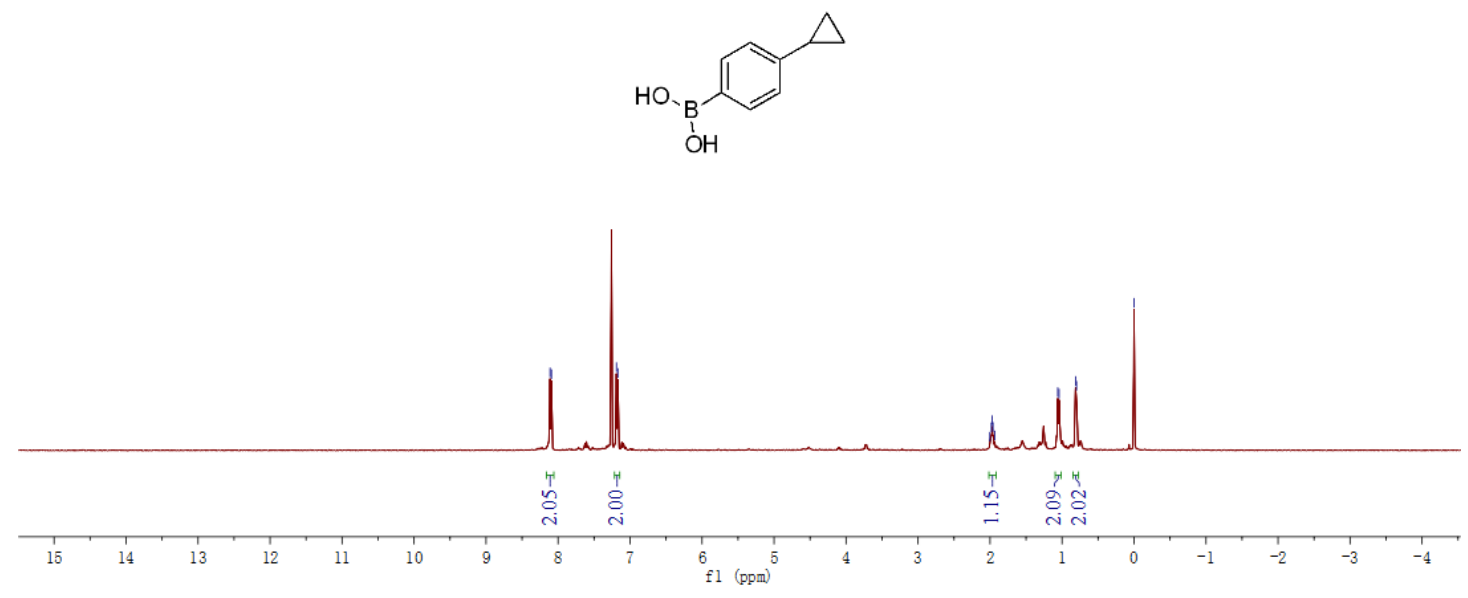

๓ั่

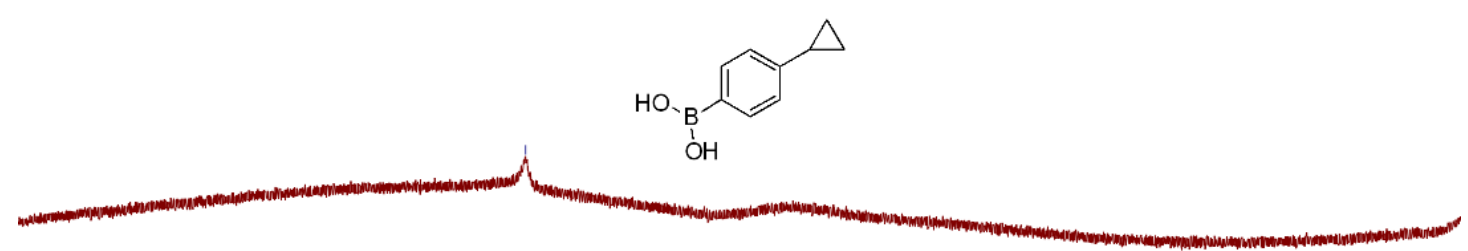




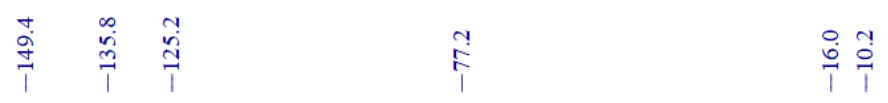

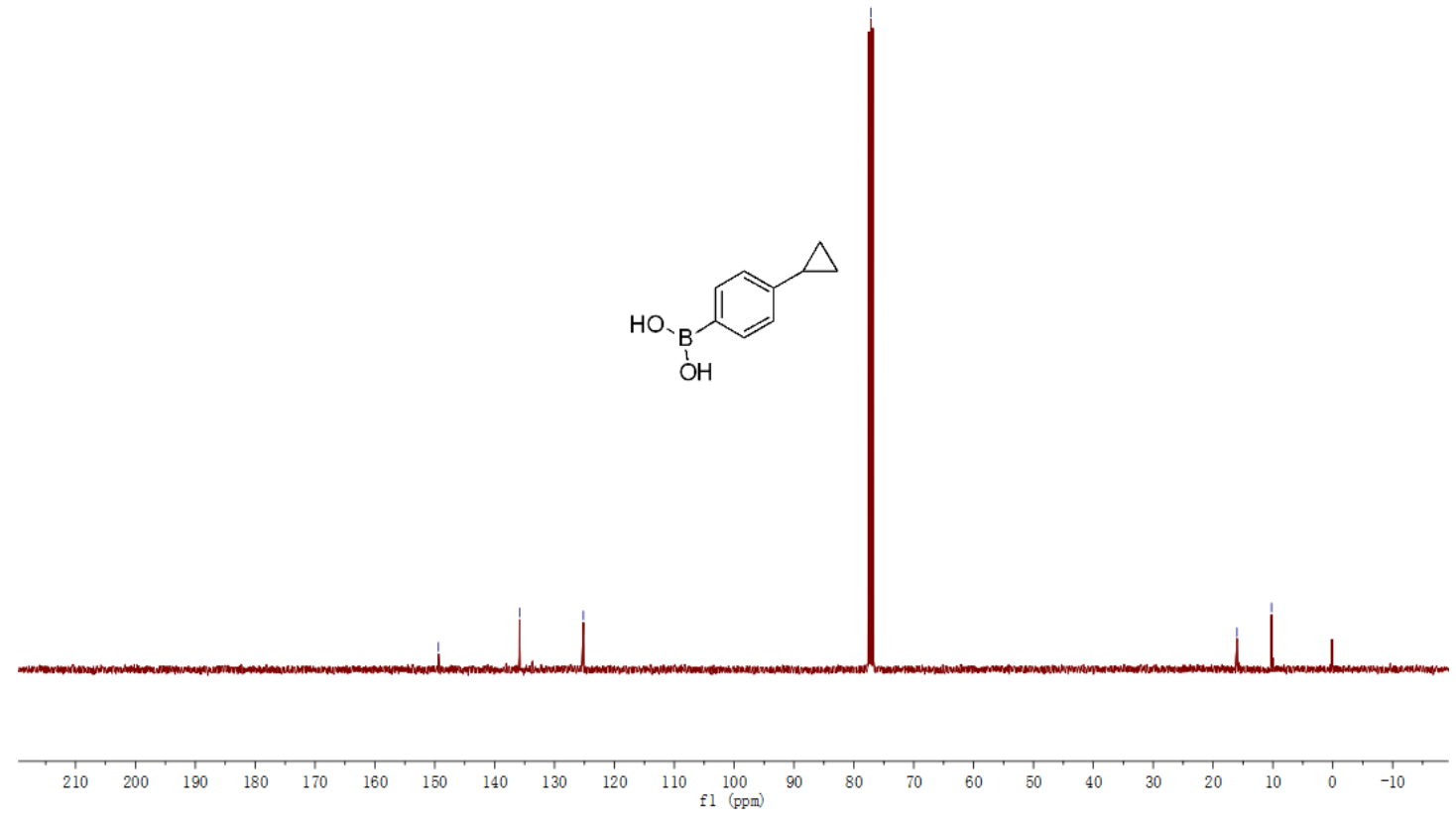

诲售

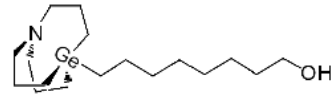

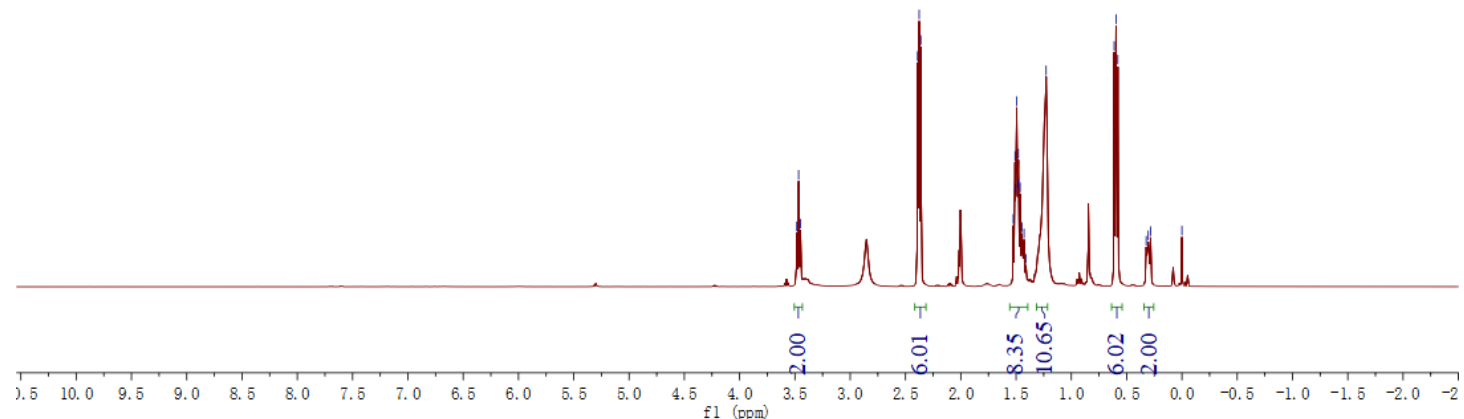



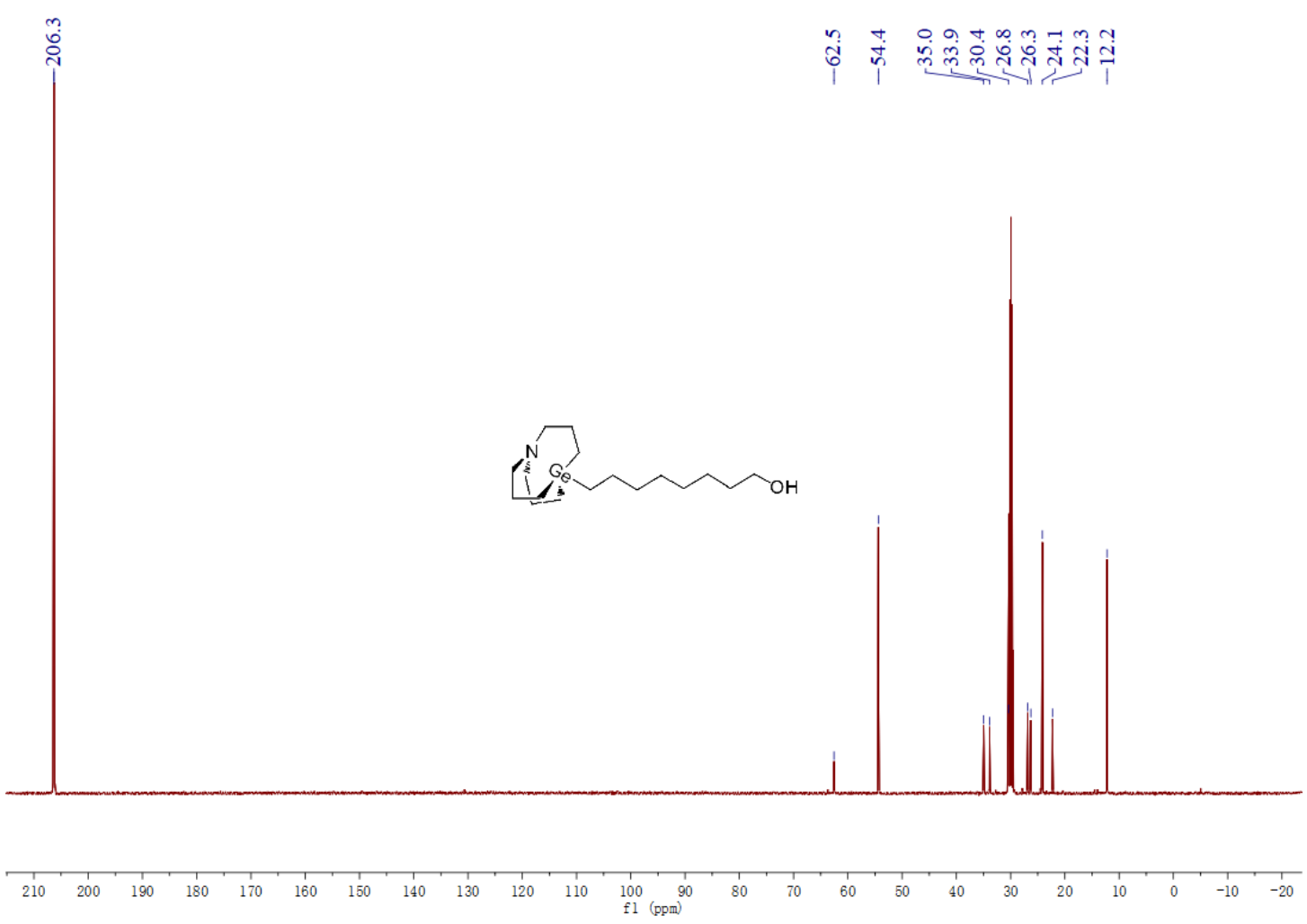

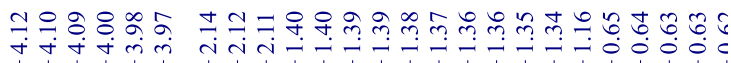

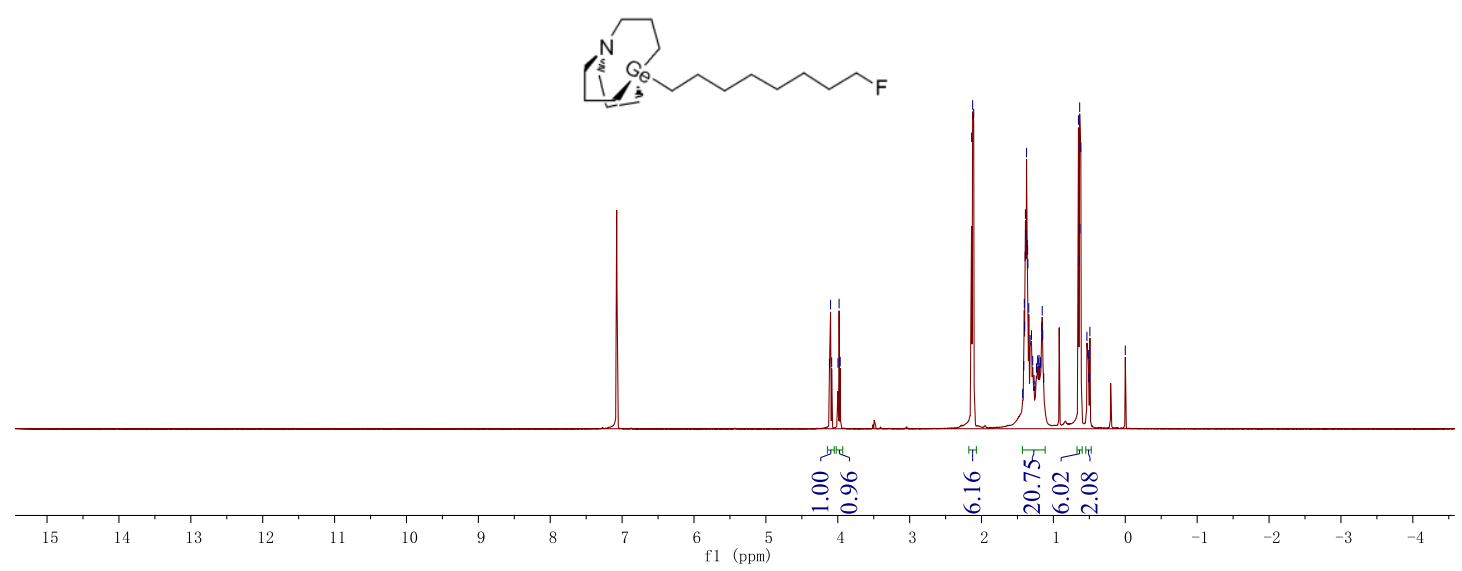



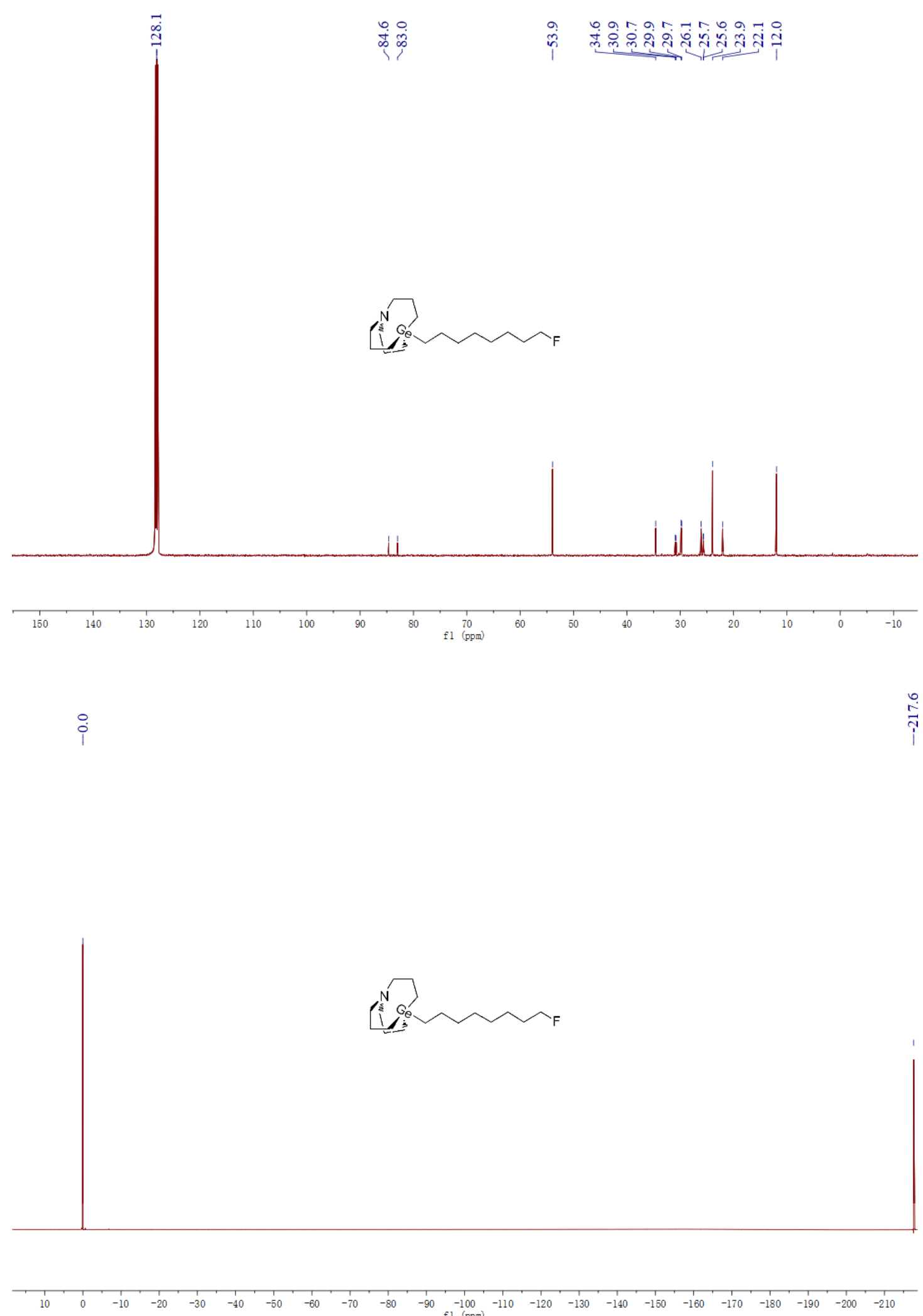


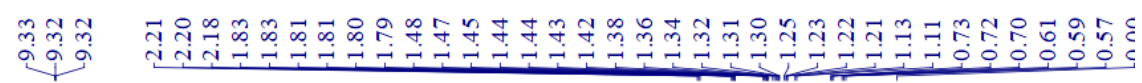
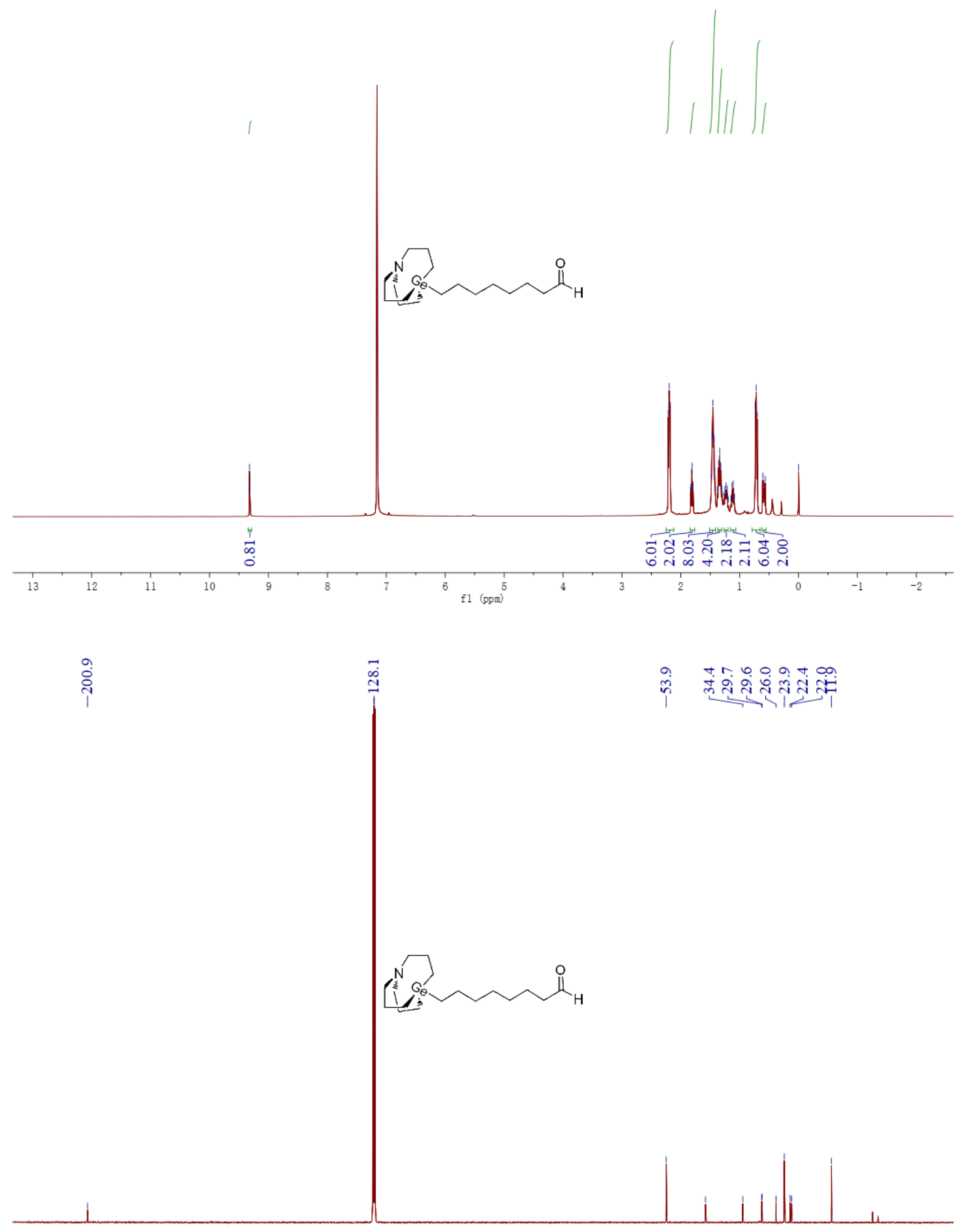

$\begin{array}{lllllllllllllllllllllllllllllll}1 & 1 & 200 & 190 & 180 & 170 & 160 & 150 & 140 & 130 & 120 & 110 & 100 & 90 & 80 & 70 & 60 & 50 & 40 & 30 & 20 & 10 & 0 & -10\end{array}$ 

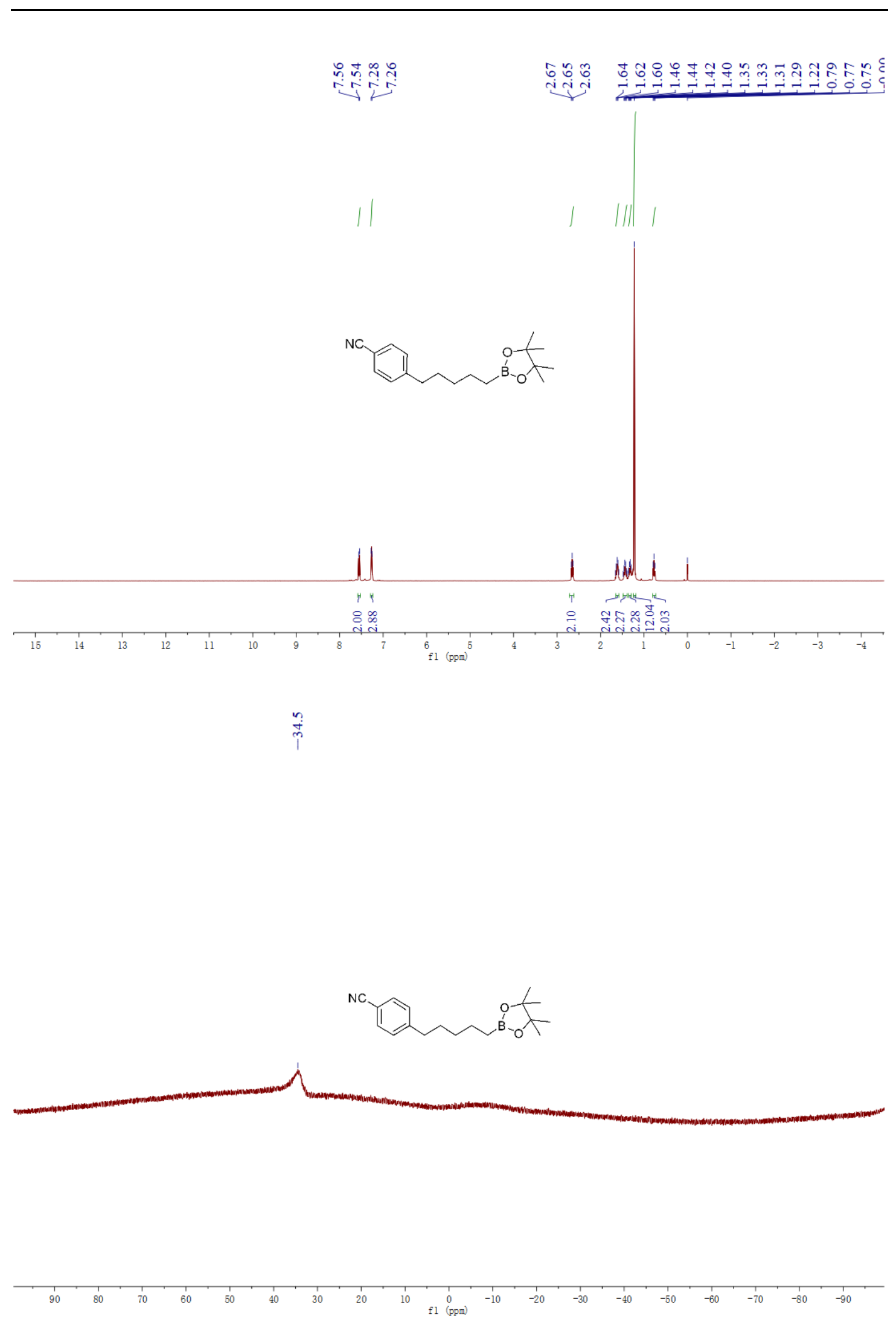

S134 


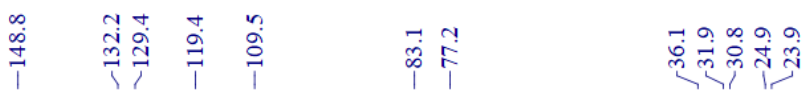
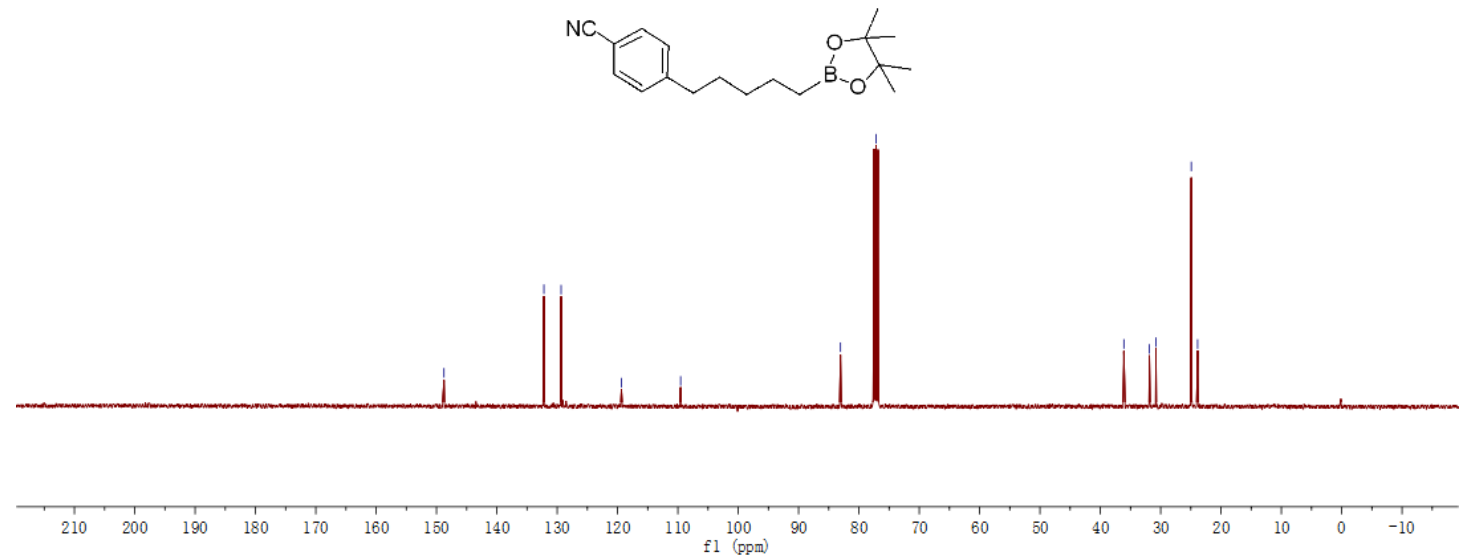

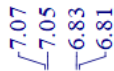

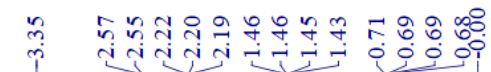

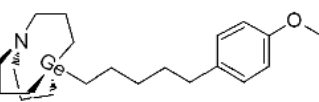
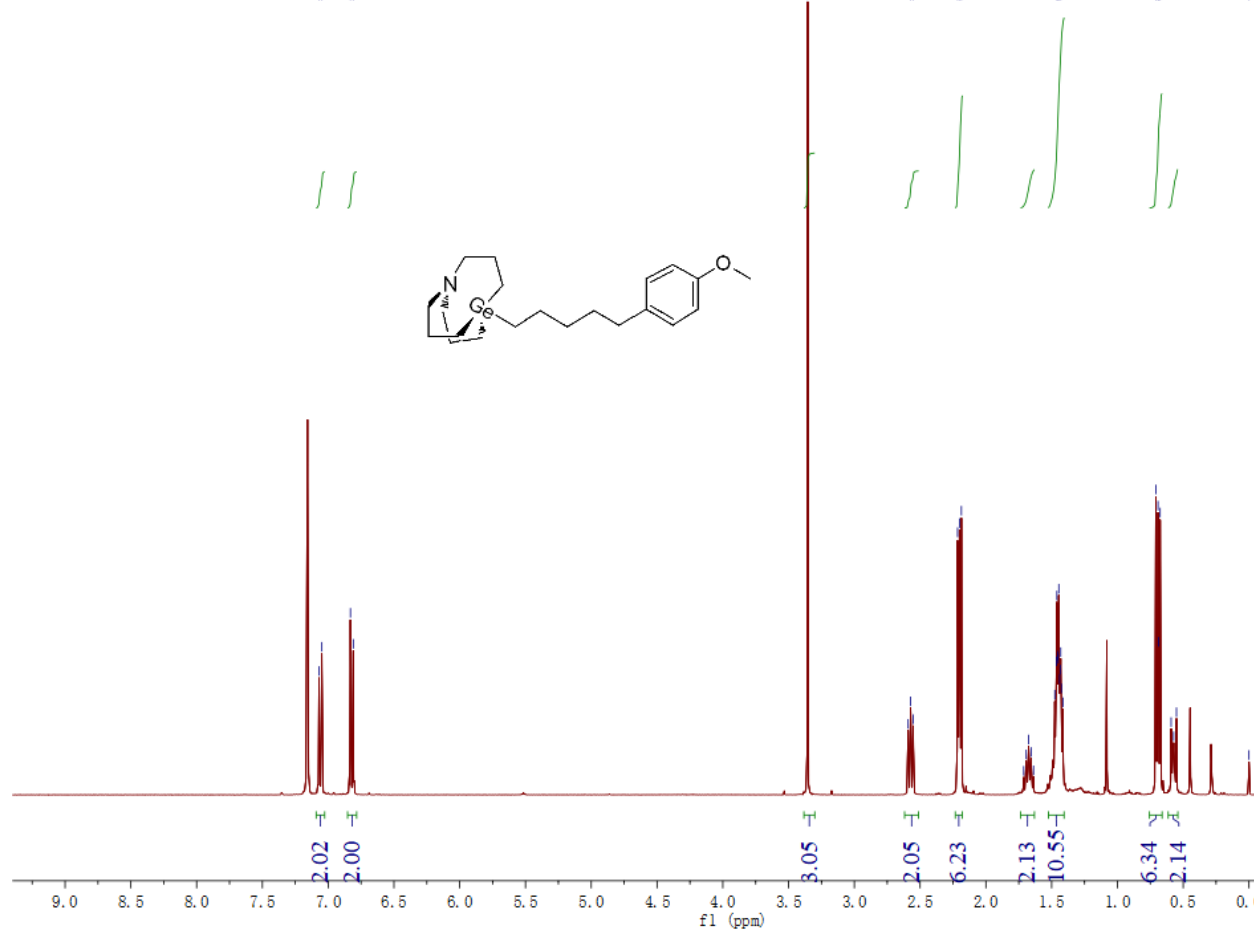

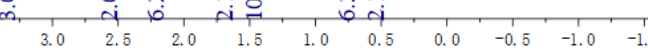



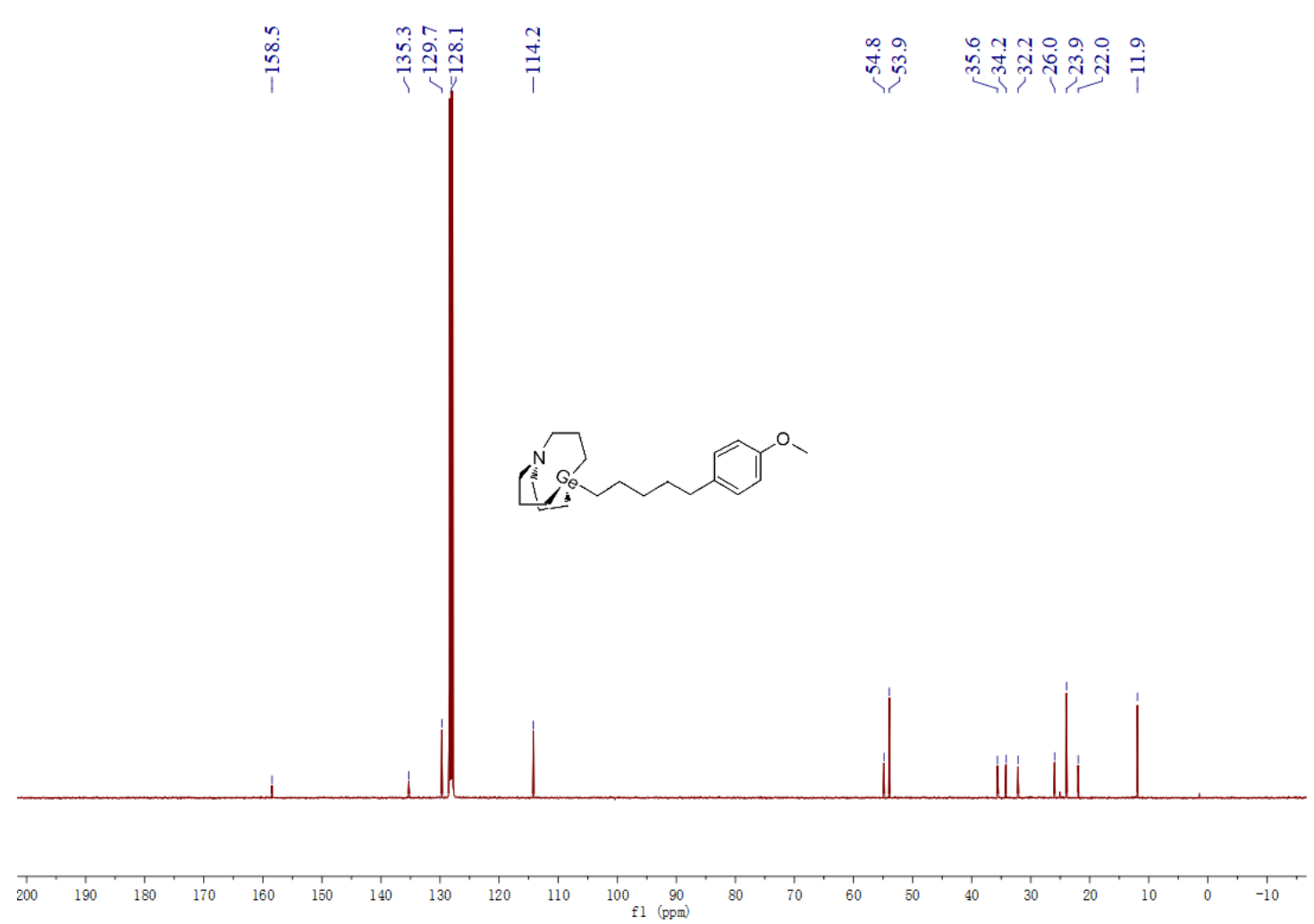

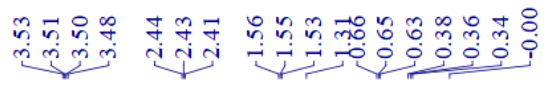

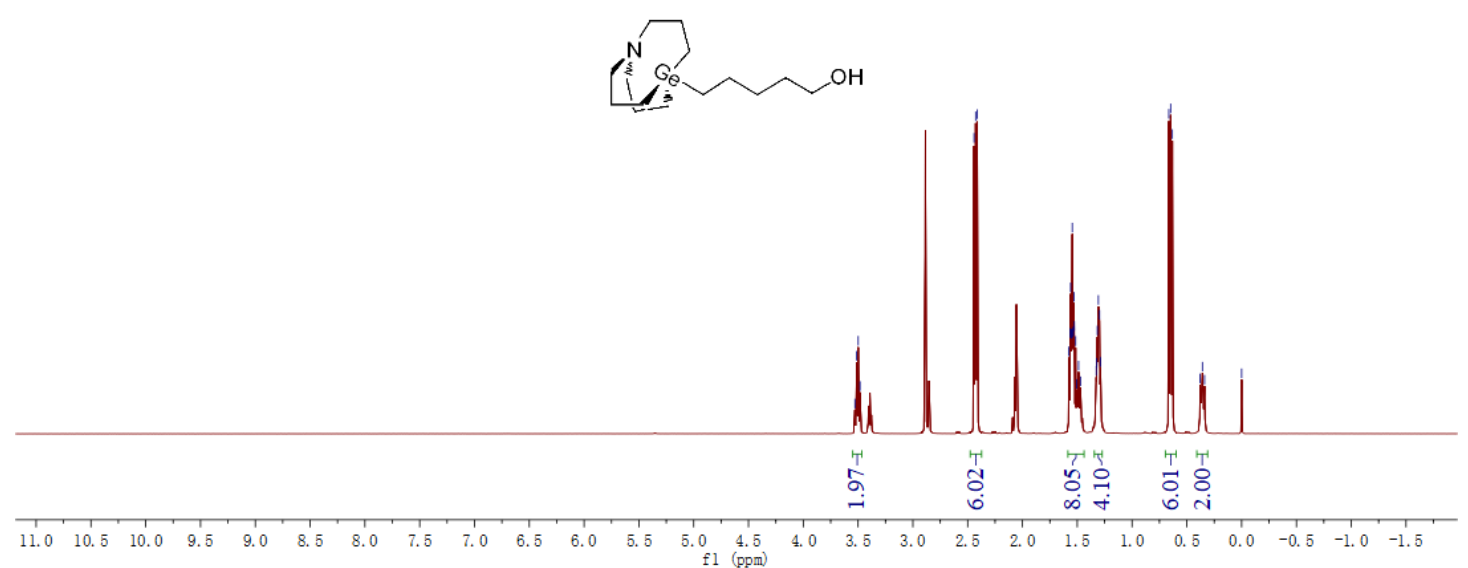


$\stackrel{3}{\mathrm{i}}$

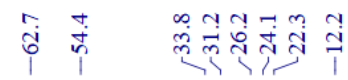

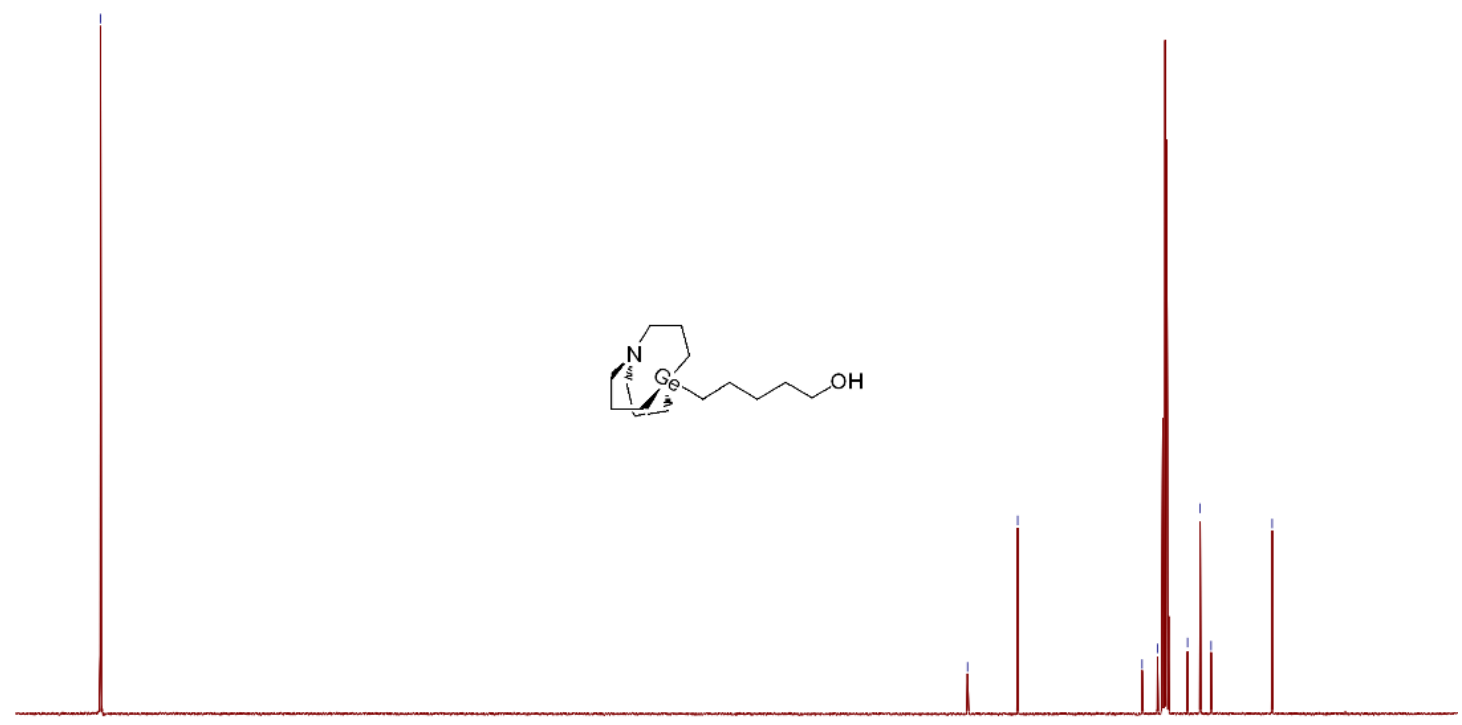

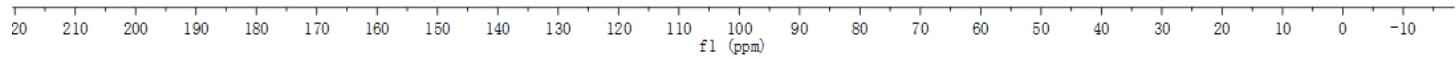

